Revista de Historia y Estética del Cine, Fotografía y Cultura Visual

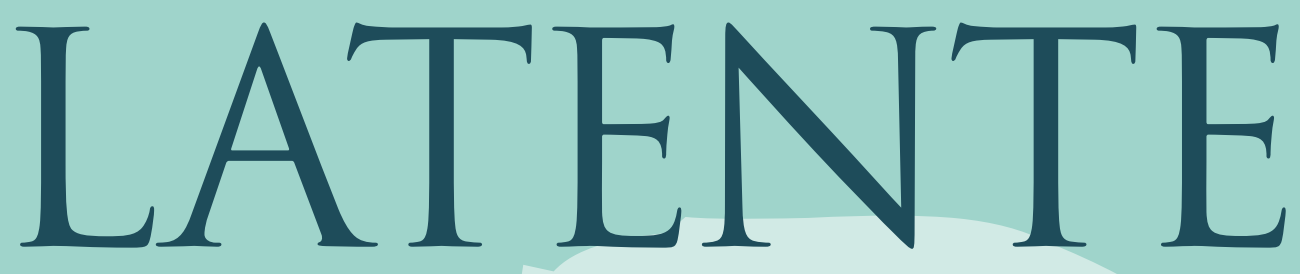

Universidad de La Laguna $19 \quad 2021$ 
Revista

LATENTE 


\author{
Revista \\ LATENTE \\ Revista de Historia y Estética del Cine, Fotografía y Cultura Visual \\ DIRECTOR \\ Domingo Sola Antequera \\ SECRETARIA \\ Alicia Hernández Vicente \\ CONSEJO DE REDACCIÓN \\ Carmelo Vega de la Rosa, Gonzalo Pavés Borges, \\ Enrique Ramírez Guedes, Isabel Castells Molina, \\ Amparo Martínez Herranz y Domingo Sola Antequera \\ CONSEJO ASESOR
}

Richard Jewell (University of Southern California, Los Angeles), Román Gubern (Universidad Autónoma de Barcelona), Ángel Luis Hueso (Universidad de Santiago de Compostela),

Santos Zunzunegui (Universidad del País Vasco), Francisco de la Plaza (Universidad de Valladolid), Manuel Palacios (Universidad Complutense de Madrid), Joaquín Cánovas (Universidad de Murcia), Alberto Elena (Universidad Autónoma de Madrid), Luciano Berriatua (investigador y restaurador, Madrid), Javier Herrera (Filmoteca Espańola), Paul Hammond (investigador y escritor, Barcelona), Lee Fontanella (Institute of Technology, Massachusetts), Joan Fontcuberta (fotógrafo y teórico, Barcelona), Bernardo Riego (Aula de Fotografía, Universidad de Cantabria)

EDITA

Servicio de Publicaciones de la Universidad de La Laguna Campus Central. 38200 La Laguna. Santa Cruz de Tenerife

Tel.: 34922319198

DISEÑO EDITORIAL

Jaime H. Vera

Javier Torres / Luis C. Espinosa

MAQUETACIÓN Y PREIMPRESIÓN

Servicio de Publicaciones

DOI: https://doi.org/10.25145/j.latente.2021.19

ISSN: 1697-459X (edición impresa) / ISSN: 2386-8503 (edición digital)

Depósito Legal: TF-1136/2003

Prohibida la reproducción total o parcial de esta obra sin permiso del editor. 


\section{Revista}

\section{LATENTE \\ 19}


REVISTA Latente: Revista de Historia y Estética del Cine, Fotografía y Cultura Visual/director, Domingo Sola Antequera. -La Laguna: Servicio de Publicaciones, Universidad de La Laguna-, 2003

Anual

ISSN: $1697-459 \mathrm{X}$

1. Medios audiovisuales-Publicaciones periódicas 2. Cine-Estética-Publicaciones periódicas 3. CineHistoria-Publicaciones periódicas I. Sola Antequera, Domingo, dir. II. Universidad de La Laguna. Servicio de Publicaciones, ed.

791.43(05)

\section{RECEPCIÓN DE ORIGINALES}

La revista Latente se edita una vez al año. Los originales para su publicación pueden remitirse a:

Domingo Sola Antequera (Departamento de Historia del Arte y Filosofía) Isabel Castells Molina (Filología Española)

Universidad de La LAguna

Campus de Guajara

38071 La Laguna (Tenerife, España)

Los trabajos no deberán exceder de 40 páginas DIN-A4 mecanografiadas a una sola cara y a doble espacio. Las recensiones no excederán las 5 páginas. Hay que incluir un resumen en español y en inglés de 10 líneas como máximo, así como las palabras clave del artículo en un máximo de 2 líneas. Los trabajos deberán ser presentados en CD (programas Word, OpenOffice o Ipages) y en dos copias en papel. Todos los trabajos serán sometidos a informe reservado de al menos dos especialistas de reconocido prestigio. Se ruega acompañen los originales con la dirección postal de la autora o autor, $e$-maily la indicación del centro donde ejerce su actividad académica o investigadora. Los trabajos no aceptados para su publicación serán devueltos a petición de la autora o autor.

Las notas y las referencias bibliográficas irán a pie de página. Se preferirá el uso de la «ChicagoDeusto» como modelo:

\section{Libros:}

Duch, Lluís, Mito, interpretación y cultura (Barcelona: Herder, 1998), 56-58.

\section{Artículos:}

Hernández Guerrero, María José, "Presencia y utilización de la traducción en la prensa española», Meta 56, n. ${ }^{\circ}$ (2011): 112-13.

Las lenguas de la revista son el espańol y el inglés.

La revista se publica anualmente y el plazo máximo para el envío de originales es el 15 de mayo de cada año.

Los envíos pueden hacerse a las siguientes direcciones: icastell@ull.es y dsola@ull.es.

La correspondencia relativa a la revista debe dirigirse a:

Servicio de Publicaciones

Universidad DE LA LAGUNA

Campus Central

38200 La Laguna (Tenerife, España) 


\section{SUMARIO / CONTENTS}

\section{ARTÍCULOS / ARTICLES}

María Magdalena. Origen e iconografía en las artes plásticas y en el cine / Mary Magdalene. Origin and iconography in Arts and Cinema

Clementina Calero Ruiz

Canarias en las primeras películas en color. Las islas en el catálogo de la compañía Kinemacolor / The Canary Islands in the Kinemacolor catalogue. The first color films

Natalia Vías Trujillo.

La crisis del comando en el cine norteamericano de guerra submarina en los períodos de posguerra: los casos de Run Silent Run Deep (Robert Wise, 1958) y Crimson Tide (Tony Scott, 1995) / The command crisis in North American submarine war cinema in the post-war periods: Run Silent Run Deep (Robert Wise, 1958) and Crimson Tide (Tony Scott, 1995) proposals Francisco Trujillo García-Ramos.

La representación de la inmigración latina en el musical estadounidense: West Side Story e In The Heights / The representation of latino immigration in the musical of the United States of America: West Side Story and In The Heights

Virginia E. Higueras Rodríguez.

El espejo deformante. Heracles en el cine del siglo xxI / The distorting mirror. Heracles in $21^{\text {st }}$ century cinema

Joana Rodríguez Pérez.

Lazzaro Felice, el héroe santo de Alice Rohrwacher / Lazzaro Felice, the Alice Rohrwacher's holy hero

Teresa Rodríguez Hage.

\section{RECENSIONES}

José Luis Sánchez Noriega (ed.) (2020). Cine español en la era digital: emergencias y encrucijadas, Laertes

Carlos Fernández Castro.

Diego Álvarez Sosa (2021). La ciudad revelada. La fotografía en Los Llanos de Aridane, Concejalía de Cultura, Excmo. Ayto. de Los Llanos de Aridane: Mestura Estudio Ediciones 

ARTÍCULOS / ARTICLES 



\title{
MARÍA MAGDALENA. ORIGEN E ICONOGRAFÍA EN LAS ARTES PLÁSTICAS Y EN EL CINE
}

\author{
Clementina Calero Ruiz* \\ Universidad de La Laguna
}

\section{RESUMEN}

María Magdalena siempre ha generado controversias, protagonizando diferentes relatos relacionados con la Pasión de Cristo. Desde un principio aparece como una discípula más, además de testigo privilegiado en su crucifixión y entierro. De todos esos momentos, posiblemente el más importante es el que tiene que ver con la resurrección, pues fue a ella a quien primero se le apareció Jesús, encomendándole la misión de comunicarlo a sus discípulos, que al principio no la creyeron, sobre todo Simón Pedro. A partir del siglo vi en adelante, su legado cambió y se convirtió en una prostituta arrepentida por el cristianismo. Este artículo trata de analizar cómo se han representado estos cambios en las artes y especialmente en el cine. Palabras Clave: Magdala, María Magdalena, Jesús de Nazareth, Evangelios.

\section{MARY MAGDALENE. ORIGIN AND ICONOGRAPHY \\ IN ARTS AND CINEMA}

\section{Abstract}

Mary Magdalene has always been a controversial issue related to the Passion of the Christ. At the very beginning she seems to be supporting the ministry of Jesus of Nazareth as his first disciple. In addition, she was involved in his crucifixion and burial and, what is more, she was the first witness of his resurrection. Due to this, Jesus entrusted her with the task of giving the good news to his disciples, but nobody trusted her, especially Simon Peter. From the 6th century onwards, her legacy changed and she became a repentant prostitute for the Christianity. This paper tries to analyze how those changes have been represented in the arts and specially in the cinema.

KeYwords: Magdala, Mary Magdalene, Jesus of Nazareth, Gospels. 


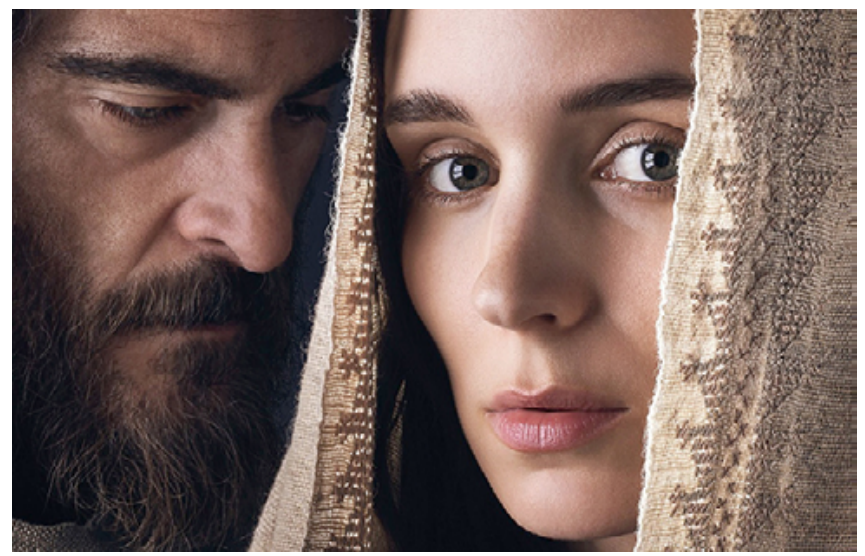

Joaquin Phoenix (Jesús) y Rooney Mara (María Magdalena) en el cartel de la película María Magdalena, Garth Davis, 2018.

Desde la versión italiana María de Magdala (María di Magdala, Carmine Gallone, 1915) hasta la más reciente María Magdalena (Garth Davis, 2018), su persona ha trasladado al celuloide su controvertida figura ${ }^{1}$. María aparece en diferentes relatos relacionados con la Pasión de Cristo, presentándose como una discípula más desde el primer momento, además de testigo privilegiado en su crucifixión y entierro. De todos esos momentos, posiblemente el más importante tenga que ver con la resurrección, pues fue a ella a quien primero se le apareció Jesús, encomendándole la tarea de comunicarlo a sus discípulos, que en principio no la creyeron, sobre todo Simón Pedro ${ }^{2}$. No obstante, su figura ha llegado hasta nosotros rodeada de polémica, como una prostituta arrepentida ${ }^{3}$.

A María la conocemos por su sobrenombre Magdalena, que supuestamente alude a su lugar de origen: Magdala. Aunque Magdala no aparece en los Evangelios,

* Profesora titular de Historia del Arte Moderno, Facultad de Humanidades, Sección de Geografía e Historia, Departamento de Historia del Arte y Filosofía, Universidad de La Laguna. Edificio Departamental de Geografía e Historia, Campus de Guajara, s/n, San Cristóbal de La Laguna, 38071. Correo electrónico: ccalero@ull.edu.es ORCID: 0000-0002-0626-8441. Academia.edu: https://ull.academia.edu/ClementinaCaleroRuiz.

${ }^{1}$ Claveras, Montserrat (2010). La Pasión de Cristo en el cine. Ed. Encuentro, Madrid, pp. 266-269.

2 Bernabé Ubieta, Carmen (2016). Se llamaba Miriam y era de Magdala. La autoridad de una mujer en los origenes del cristianismo. Conferencia pronunciada en el Foro Gogoa, Pamplona, el 16 de marzo de 2016. En https://forogogoa.org/es/conferencia/se-llamaba-miriam-y-era-de-magdala-la-autoridad-de-una-mujer-en-el-naciente-cristianismo/ [consultado en 16/5/2021].

${ }^{3}$ Apócrifo Gnóstico. Evangelio de María Magdalena (2006). Prólogo de Juli Peradejorni, Ed. Obelisco, Barcelona, p. 9. 
Jesús sí que visitó el lugar, pues allí vivía María, su seguidora más fiel ${ }^{4}$. El nombre deriva del hebreo Mijdal, que significa torre o atalaya, y el sitio se localizaría en la zona occidental de la ribera del lago Tiberíades, también conocido como mar de Galilea o lago de Genesaret. El emperador Teodosio es uno de los primeros que citan la villa en el año 530, en su De Tiberiada nosque Magdala,ubi donna Maria nata est, milla II. Magdala nosque al septem fontes milia $I^{5}$.

También el historiador judío Flavio Josefo aporta información al respecto llamándola por su nombre griego Tariquea, que significa saladero de pescado ${ }^{6}$, mientras que los Evangelios la citan por su nombre en arameo אלדגמ, pronunciado Magdalá en arameo targúmico o Magdála en arameo siríaco. Josefo indica su emplazamiento a orillas del lago, narrando con detallismo su asedio por parte del emperador Vespasiano ${ }^{7}$.

Los escritos que derivan de la literatura rabínica identifican la Magdala evangélica con la Tariquea de Flavio Josefo, la actual Mijdal,

For as I know that this city of yours [Taricheae] was a city of great hospitality, and filled with an abundasnce of such men as having left their own countries, and are come hither to be partakers of your fortune, whatever it be, I had a mind to build walls about it...8.

A pesar de todo, los primeros peregrinos cristianos, como la viajera y escritora hispana Egeria -natural de la provincia Gallaecia-, que visitó los Santos Lugares entre los años 381 y 384, dice poco del sitio. Egeria solo refiere en su Itinerarium que había estado en Magdalum? ${ }^{9}$, indicando que había una fortaleza que tiene al mando un oficial con su tropa que gobierna en nombre de la autoridad romana ${ }^{10}$, pero no escribe nada más. Sin embargo otros viajeros posteriores sí que conocen muy bien el emplazamiento, referenciando su localización exacta,

${ }_{4}^{4}$ Arqueología de la Biblia. Parte 2. Nuevo Testamento. «Capítulo 2: Arqueología de la vida de Jesús. Los Evangelios de Mateo, Marcos, Lucas y Juan». National Geographic, Edición Especial, p. 84.

${ }_{5}^{5}$ Bernabé Ubieta, Carmen (2007). María Magdalena. Tradiciones en el cristianismo primitivo. Madrid, Editorial Verbo Divino, p. 22.

${ }^{6}$ En el lugar había una industria de salazón de pescado, de ahí su nombre Migdal Nunnayh, traducido como torre de pescadores. Cfr. Bernabé Ubieta, C., p. 23.

7 Flavio Josefo (1992). Josefo. Los escritos esenciales. Adaptación por Paul L. Maier. Michigan, Ed. Portavoz, Michigan (USA), pp. 294-297.

${ }^{8}$ Ristine, Jennifer (2018). Mary Magdalene. Insights from ancient Magdala. Amazon Italia Logística S.r.l., Torrazza Piemonte (TO), Italy, p. 18.

${ }^{9}$ Viaje de Egeria. El primer relato de una viajera hispana (2017). Edición, prólogo, traducción y notas de Carlos Pascual, Ed. La Línea del Horizonte, Madrid, p. 81. En la nota 36, p. 140 se escribió que a veinticuatro kilómetros al norte de Clysma, se hallaba un migdol o fortaleza que daría nombre a Magdalum o Magdala.

${ }^{10}$ Otero Pereira, Eduardo (2018). Mujeres viajeras de la Antigüedad. Los relatos de Egeria y otras peregrinas en Tierra Santa. Ed. Sígueme, Salamanca, p. 83. 
a orillas del lago, a una distancia igual de Tiberíades y de Tabga. Aluden al recuerdo de María Magdalena en este lugar y citan un monumento conmemorativo, la iglesia que albergaba la casa de María, que según el Liber Demostrationis fue mandada construir por Sta. Helena (s. IV) ${ }^{11}$.

Los evangelistas hablan de María Magdalena en diferentes momentos de la vida pública de Jesús, indicando Lucas que ella fue una de las mujeres que Jesús aceptó como discípula; detalle considerado extraordinario, teniendo en cuenta los prejuicios del judaísmo de la época. Incluso llega a afirmar que procedía de una familia acomodada, ya que apoyaba el movimiento con sus propios medios (Lc 8, 2-3).

Marcos sitúa su presencia en tres episodios fundamentales de la Pasión, como la crucifixión, el entierro y la resurrección. En la crucifixión $(15,40)$ escribe que

Estaban también mujeres mirando desde lejos, entre ellas María la Magdalena, y María la madre de Santiago el Menor y de José y Salomé, las que eran en Galilea siguiéndole y sirviéndole, y otras muchas que habían subido con él a Jerusalén.

En el entierro $(15,47)$ nos dice que María la Magdalena y María la de José contemplaban donde era puesto. Y finalmente en la resurrección $(16,1)$ indica que,

pasado el sábado María la Magdalena y María la de Santiago y Salomé compraron aromas para ir a embalsamarle. Y muy de madrugada, el primer día de la semana van al sepulcro, a la salida del sol. Y se decían unas a otras: «¿Quién nos retirará la piedra de la puerta del sepulcro?». Y alzando la vista ven que la piedra estaba retirada, aunque era muy grande. $Y$ entrando al sepulcro vieron un joven sentado a la derecha vestido con una túnica blanca, y se asustaron.

Y el joven les dice:

No temáis ¿Buscáis a Jesús, el Nazareno, el crucificado? Ha resucitado, no está aquí, ved el lugar donde le habían puesto. Ahora, id y decid a sus discípulos, y a Pedro, que va delante de vosotras a Galilea, allí le veréis, como os dijo.

Mateo también ubica a Magdalena en los episodios finales de la Pasión, y coincide con Marcos en la aparición de Jesús a la salida del sepulcro y en el aviso a los discípulos. Y entre el grupo de mujeres presentes en ese momento, añade a la madre de los hijos del Zebedeo ${ }^{12}$.

Juan, por su parte, la nombra a los pies de la cruz $(19,25)$, declarando que permanecian junto a la cruz de Jesús, su madre y la hermana de su madre María la de Klopás y María la Magdalena. También la sitúa en la visita al sepulcro en el huerto (2, 1-18), pero, a diferencia de los restantes evangelistas, a la sepultura va ella sola,

11 Bernabé Ubieta, Carmen (2007). María Magdalena. Tradiciones en el cristianismo primitivo. Editorial Verbo Divino, Madrid, p. 25.

12 Bernabé Ubieta, Carmen (2007). María Magdalena. Tradiciones en el cristianismo primitivo. Editorial Verbo Divino, Madrid, p. 65. 


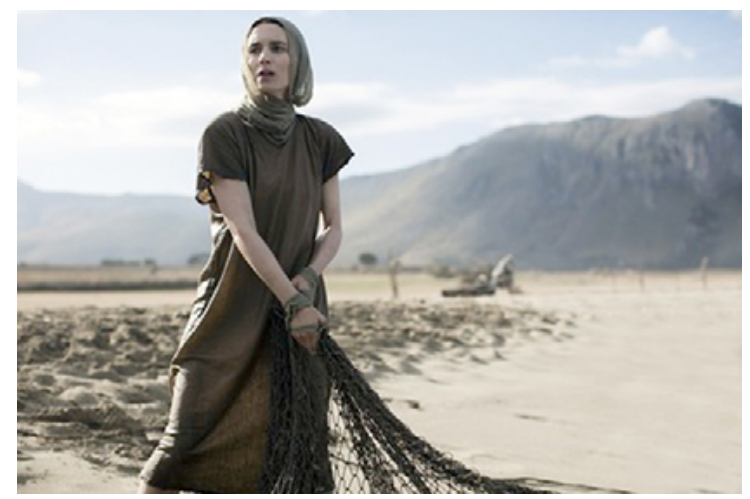

Rooney Mara como María Magdalena (Garth David, 2018).

no se hace acompañar de otras mujeres. Y al verlo vacío llora amargamente, pero al darse la vuelta,

Vio a Jesús de pie, pero no sabía que era él. Le dice Jesús: «Mujer ¿por qué lloras, a quién buscas?». Ella pensando que era el encargado del huerto, le dice: «Señor, si tú te lo has llevado dime dónde lo has puesto, y yo me lo llevaré». Jesús le dice: «María». Ella se vuelve y le dice en hebrero: «Rabbunni» que quiere decir «Maestro». Le dice Jesús: Deja de agarrarme pues aún no he subido al Padre. Pero vete a mis hermanos y diles: «Subo a mi Padre y a vuestro Padre, a mi Dios y a vuestro Dios». Fue María Magdalena a los discípulos y anunció: «He visto al Señor y que le había dicho estas cosas» $(20,14-17)$.

De los cuatro evangelistas, Lucas es el único que nos dice que Magdalena sigue a Jesús desde un principio (Lc 8, 1-3), cuando aquél iba anunciando el Reino de los Cielos, y se le acercaban las mujeres como María la llamada Magdalena de la que habia sacado siete demonios y Juana mujer de Cusa, administrador de Herodes y Susana y otras muchas, que les servian con sus bienes $(8,1)$. Siempre la coloca la primera, nombrándola como una auténtica discípula que siguió sus pasos desde Galilea hasta Jerusalén.

Al respecto y llegados a este punto, la película María Magdalena (Mary Magdalene, Garth Davis, 2018), ambientada en Tierra Santa en el siglo I, es quien mejor la retrata siguiendo el relato de Lucas, pues la sitúa viviendo en una aldea de pescadores a orillas del lago Tiberíades, en una familia acomodada, donde junto a otras mujeres se dedica a pescar, recoger las redes y coserlas. Su familia, siguiendo la tradición, quiere casarla con un rico viudo, pero ella lo rechaza y se dedica a orar. Son tantos sus rezos que su hermano llega a decirle: si quieres te vendo los pechos para que puedas orar siempre como los hombres. En vista de esta situación y creyéndola poseída, una noche deciden sacarla de su alcoba y llevarla a la orilla del lago para practicarle un exorcismo y sacarle los «demonios». Para ello la conducen ante el profeta, que por esos días estaba predicando por el lugar, a quien le piden que hable con ella. Magdalena (Rooney Mara) le dice a Jesús (Joaquin Phoenix): si hay 
un demonio en mí, siempre lo ha habido; a lo que aquél le responde: no hay demonios aqui, Maria de Magdala.

María le manifiesta que desea conocer a Dios porque ha sentido su presencia, de modo que, tras recuperarse del duro trance al que la ha sometido su familia, decide abandonar su casa y unirse a Jesús, ya convertido en un líder carismático que predica el cambio del mundo. María persigue una nueva forma de vida, que no la anule como mujer, de modo que no duda en abandonar ese núcleo familiar inflexible que la asfixia y le niega su condición femenina. Al enterarse, su padre y su hermano la persiguen, ordenándole que regrese al hogar, pero ella no los escucha, dirigiéndose hacia la orilla del lago para que Jesús la bautice. A partir de ese momento, María comienza su viaje espiritual como protagonista, aumentando su importancia al tiempo que aumenta la notoriedad del grupo. Comienza predicando primero en Magdala, continuando luego su camino como una discípula más hasta Jerusalén.

Si bien los discípulos la aceptan como una más, Simón Pedro (Chiwetel Ejiofor) no ve con buenos ojos que María se sume a un grupo formado mayoritariamente por hombres, alegando que ella los dividirá, llegando incluso a insinuarle que no era justo que la hubiera elegido a ella como nuestra guí. En el Evangelio de Tomás (Logión CXIV), se advierte claramente cómo Pedro no le tenía mucha simpatía, llegando a pedirle a Jesús que salga de entre nosotros, pues las mujeres no son dignas de la Vida ${ }^{13}$. El propio Jesús intenta disculpar estas palabras, y le dice a María que los apóstoles hablan como soldados, preguntándole si ella quiere ser un soldado también. Ella replica que no, aunque añade que la opinión de las mujeres no cuenta mucho. Pero Pedro sigue insistiendo, de modo que en una ocasión llega a decirle $m i$ Señor no podemos aguantar a esta mujer que nos quita la oportunidad de hablar y no permite que nadie hable porque ella lo hace muchas veces ${ }^{14}$. Esta situación se repite en muchas ocasiones en los textos y también en el filme.

Magdalena, como mujer, es quien se dirige a las mujeres que se encuentran por los caminos, en los lavaderos, a las que exhorta y bautiza; esas mismas mujeres que al ser preguntadas por lo que hacen responden que son mujeres por lo que su vida no les pertenece. María les responde que su espíritu sí es de ellas, que son libres, por lo que la mayoría terminan por unírseles y sumarse a la causa.

Como señala Carmen Bernabé, para Lucas

María Magdalena y sus compañeras pertenecen a aquel grupo de discípulos de Jesús. Ellas le acompañan, junto con los Doce, como signos efectivos de la llegada

${ }_{13}$ Apócrifo Gnóstico. Evangelio de María Magdalena (2006). Prólogo de Juli Peradejorni, Ed. Obelisco, Barcelona, p. 19.

14 Bernabé Ubieta, Carmen (2016). Se llamaba Miriam y era de Magdala. La autoridad de una mujer en los orígenes del cristianismo. Conferencia pronunciada en el Foro Gogoa, Pamplona, el 16 de marzo de 2016. En https://forogogoa.org/es/conferencia/se-llamaba-miriam-y-era-de-magdala-la-autoridad-de-una-mujer-en-el-naciente-cristianismo/ [consultado en 16/5/2021]. 


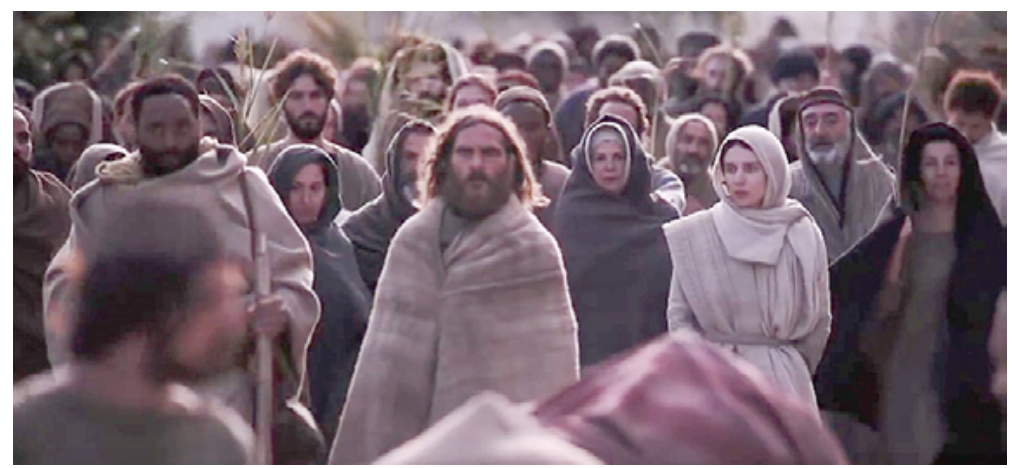

Fotograma de la película Maria Magdalena (Garth David, 2018).

del Reino. María Magdalena es una discípula de los de la primera hora, que va a iniciar el aprendizaje, mientras acompaña a Jesús en su viaje a Jerusalén ${ }^{15}$.

Camino de Jerusalén se encuentran con María, la madre de Jesús, que en compañía de otras mujeres acude a la ciudad para la celebrar la Pascua, produciéndose un intenso diálogo entre ambas, especialmente cuando aquélla le pregunta: Amas a mi hijo, ¿verdad? Pues entonces debes prepararte, como yo, para perderlo. Añadiendo que ella también lo amaba pero nunca fue del todo suyo, ofreciéndonos una visión más humana y cercana de la Madre.

Magdalena continúa con su misión, predicando y bautizando, pues la tradición no permitía que se bautizaran juntos hombres y mujeres, pero Jesús la autoriza a bautizar en su nombre, diciéndole ve con ellos... sé mis manos. Es tal la importancia que Magdalena alcanza que en una ocasión en que Jesús manda a Pedro a predicar a Samaria, le ordena que la lleve con él. Este detalle lo incomoda, pues no ve correcto que una mujer lo guíe, ya que él prefería hacerlo solo, como indicamos anteriormente.

Respecto a su presencia en la crucifixión, Lucas refiere que

permanecían todos sus conocidos a distancia y unas mujeres, las que le seguían desde Galilea presenciaban estas cosas (Lc, 23, 49).

Y, en relación con la resurrección, cuando acude al sepulcro con las otras mujeres, escribe que se le presentaron dos hombres vestidos resplandecientes y

volviendo del sepulcro anunciaron todas estas cosas a los Once y a todos los demás. Y eran la Magdalena María y Juana y María la de Santiago y las demás con ellas, las

15 Bernabé Ubieta, Carmen (2007). María Magdalena. Tradiciones en el cristianismo primitivo. Editorial Verbo Divino, Madrid, p. 115. 
que decían a los apóstoles estas cosas pero aparecían delante de ellos como desatinos estas cosas y no les creían. Y Pedro levantándose corrió al sepulcro e inclinándose vio solo las vendas y regresó a su casa asombrado por lo sucedido. (Lc 24, 9-12).

En el Evangelio apócrifo de Pedro (Pedro, 50-57) [fragmento de Akhmîn], en relación con este momento de la resurrección y visita al sepulcro, se la nombra junto con otras mujeres, de las que solo se dice que eran sus amigas, pero en ningún momento se indica que fuera a avisar a los discípulos, solo se escribió que las mujeres aterrorizadas huyeron:

A la mañana del domingo, María la de Magdala, discípula del Señor -atemorizada a causa de los judíos, pues estaban rabiosos de ira, no había hecho en el sepulcro del Señor lo que solían hacer las mujeres por sus muertos queridos-, tomó a sus amigas consigo y vino al sepulcro en que había sido depositado.

Más temían no fueran a ser vistas por los judíos y decían: «Ya que no nos fue posible llorar y lamentarnos el día aquel en que fue crucificado, hagámoslo ahora por lo menos cabe su sepulcro.

Pero, ¿quién nos removerá la piedra echada a la puerta del sepulcro, de manera que, pudiendo entrar, nos sentemos junto a él y hagamos lo que es debido?

Pues la piedra era muy grande y tenemos miedo no nos vaya a ver alguien. Y si (esto) no nos es posible, echemos al menos en la puerta lo que llevamos en memoria suya; lloremos y golpeémonos el pecho hasta que volvamos a nuestra casa».

Fueron, pues, y encontraron abierto el sepulcro. Y en esto ven allí un joven sentado en medio de la tumba, hermoso y cubierto de una vestidura blanquísima, el cual les dijo:

"¿A qué habéis venido? ¿A quién buscáis? ¿Por ventura a aquel que fue crucificado? Resucitó ya y se marchó. Y si no lo queréis creer, asomáos y ved el lugar donde yacía. No está, pues ha resucitado y ha marchado al lugar aquel de donde fue enviado».

Entonces las mujeres aterrorizadas huyeron ${ }^{16}$.

Como hemos comentado al principio, de la lectura de determinados episodios tanto de los Evangelios Canónicos como Apócrifos de diferentes épocas y autores, se desprende la aparente mala relación que existía entre Magdalena y Pedro. Lucas intenta disimularlo favoreciendo la autoridad de Simón Pedro, diciendo que fue a él a quien se le encomendó el aviso a los discípulos en relación con la resurrección. Así es que elimina la aparición del Resucitado a María y a sus compañeras, cuyas palabras son tomadas por los discípulos varones como tonterias o cosas de trastorna-

16 Santos Otero, Aurelio de (1984). Los Evangelios Apócrifos. Biblioteca de Autores Cristianos, Madrid, pp. 391-393. 
$\operatorname{das}^{17}$. Y también elimina el envío del ángel a las mujeres. Posteriormente en Hechos (siglo Iv) Magdalena aparece junto a Tomás y Mateo. Se dice que el Resucitado le dio el encargo de acompañar a Felipe en su viaje y se la llama apóstol, describiéndosela predicando y convirtiendo a las masas, sanando con su saliva y practicando exorcismos. Pero, según Carmen Bernabé, cuando el texto se tradujo al copto, Magdalena - de nuevo- fue sustituida por Pedro; de modo que será Pedro quien haga todo lo que en el original hacía María.

Obviamente, el hecho de que Jesús se le apareciera a ella es la razón en la que se apoya el reconocimiento de su autoridad, de modo que no es extraño que a partir del siglo Iv, no solo se la sustituya por Pedro, sino que se señale que en el Jardín del Huerto, Jesús a quien se le apareció fue a María, su madre. Y así se advierte en el texto copto del Apóstol Bartolomé, que refiere que es María de Nazaret quien habla con el Resucitado, y luego va a comunicarlo a los discípulos.

De modo que

María Magdalena pasó de testigo, discípula y receptora de una cristofanía a prostituta arrepentida mediante un proceso paulatino que se completó en los siglos VI-VII con Gregorio Magno, aunque se hayan producido algunos episodios anteriores ${ }^{18}$.

En una carta apócrifa que le escribe el emperador Tiberio a Pilato ${ }^{19}$, acusándolo de haber entregado a Jesús a muerte sin motivo aparente, el emperador le hace partícipe de su preocupación porque ha venido a su presencia una mujer,

la cual se dice discípula de Él (es María Magdalena, de quien, según afirma, expulsó siete demonios), y atestigua que Jesús obraba portentosas curaciones, haciendo ver a los ciegos, andar a los cojos, oír a los sordos, limpiando a los leprosos, y que todas estas curaciones las verificaba con sola su palabra. ¿Cómo has consentido que fuera crucificado sin motivo alguno? Porque, si no queríais aceptarlo como Dios, deberíais al menos haberos compadecido de Él como médico que es (...).

Aunque no deja de ser una historia apócrifa, solo Magdalena, presentándose como discípula, y armada de valor, acude ante el emperador Tiberio para defender la memoria de su Maestro. Recordar, al respecto, que Pedro, al ser apresado Jesús y llevado ante el Sanedrín, negó conocerlo y tener ninguna relación con Él.

17 Bernabé Ubieta, Carmen (2016). Se llamaba Miriam y era de Magdala. La autoridad de una mujer en los orígenes del cristianismo. Conferencia pronunciada en el Foro Gogoa, Pamplona, el 16 de marzo de 2016. En https://forogogoa.org/es/conferencia/se-llamaba-miriam-y-era-de-magdala-la-autoridad-de-una-mujer-en-el-naciente-cristianismo/ [consultado en 16/5/2021].

${ }^{18}$ Bernabé Ubieta, Carmen (2016). Se llamaba Miriam y era de Magdala. La autoridad de una mujer en los orígenes del cristianismo. Conferencia pronunciada en el Foro Gogoa, Pamplona, el 16 de marzo de 2016. En https://forogogoa.org/es/conferencia/se-llamaba-miriam-y-era-de-magdala-la-autoridad-de-una-mujer-en-el-naciente-cristianismo/ [consultado en 16/5/2021].

${ }^{19}$ Apócrifos de la pasión y resurrección. Ciclo de Pilato, Escritos complementarios: Carta de Tiberio a Pilato, Cfr. Santos Otero, Aurelio de (1986). Los Evangelios Apócrifos. p. 474. 


\section{LA IMAGEN POPULAR DE MARÍA MAGDALENA}

El proceso de transformación de María Magdalena pasó por tres momentos. Primero se identificó a María de Betania (la hermana de Marta y Lázaro) con la pecadora citada por Lucas (7: 36-50), presuponiéndose que era una prostituta. En el segundo momento identifican a María Magdalena con María de Betania, la pecadora-prostituta, y el estoque final lo pone Gregorio Magno, cuando identifica a María Magdalena con la pecadora citada por Lucas ${ }^{20}$. Efectivamente, en el siglo VI, el 21 de septiembre del año 521, cuando el papa Gregorio I (san Gregorio Magno) predica su homilía en la basílica de San Clemente de Roma, y en aras de ejemplificar el perdón, mezcla diferentes pasajes y personajes de los Evangelios, terminando por trastocar por completo la imagen de María Magdalena, a la que convierte en una prostituta; título que la ha acompañado hasta el siglo xx, en el que el papa Juan Pablo II, en 1988, con ocasión del año mariano, la definió en su Carta Apostólica como Mulieris Dignitatem ${ }^{21}$.

Como escribe Jennifer Ristine, «the conflation of Mary of Magdala with Mary of Bethany (John 12:1-8) and the sinful woman who anoints Jesus'feet (Luke 7:36-38) reinforced her reputation in Christian theology as a woman of ill repute ${ }^{22}$.

Ella, a quien Lucas llama mujer pecadora, a quien Juan llama María, creemos que es la María de la que fueron expulsados siete demonios, según nos cuenta Marcos. ¿Y qué significaban estos siete demonios sino los vicios? [...] está claro hermanos, que la mujer usó previamente el ungüento para perfumar su cuerpo en actos prohibidos. Eso que antes desplegaba de la manera más escandalosa es lo que ahora ofrece a Dios de la manera más admirable ${ }^{23}$.

Posteriormente, en el siglo XIII el dominico italiano Jacopo da Varazze (Jacopo della Voragine), castellanizado Santiago de la Vorágine, escribe La Leyenda Dorada, cuyo primer manuscrito salió a la luz en 1260, terminando por generar el caos. La obra había sido escrita con la intención de propiciar la religiosidad popular, pero a costa de la verosimilitud y la fidelidad histórica, como denunciaron en su momento los humanistas Juan Luis Vives y Melchor Cano. Según el obispo dominico, María se apodaba Magdalena por el castillo de Magdalo, en Betania, donde vivió, y era hermana de Marta y Lázaro, quienes tras el fallecimiento de sus padres pasaron

${ }^{20}$ Monreal y Tejada, Luis (2000). Iconografía del cristianismo. Ed. Acantilado, Madrid, p. 346.

${ }^{21}$ Juan Pablo II: Cartas Apostólicas, 1988. En https://www.vatican.va/content/john-paul-ii/ es/apost_letters/1988/documents/hf_jp-ii_apl_15081988_mulieris-dignitatem.html [consultado el 29 de junio de 2021].

${ }_{22}$ Ristine, Jennifer (2018). Mary Magdalene. Insights from ancient Magdala. Amazon Italia Logística S.r.l., Torrazza Piemonte (TO), Italy, p. 55.

${ }^{23}$ López, Alejandro I. (2018). El Papa que convirtió a María Magdalena en pecadora para evitar que opacara a Pedro. Texto completo en https://culturacolectiva.com/historia/gregorio-i-convirtio-a-maria-magdalena-en-prostituta [consultado el 25 de mayo de 2021]. 


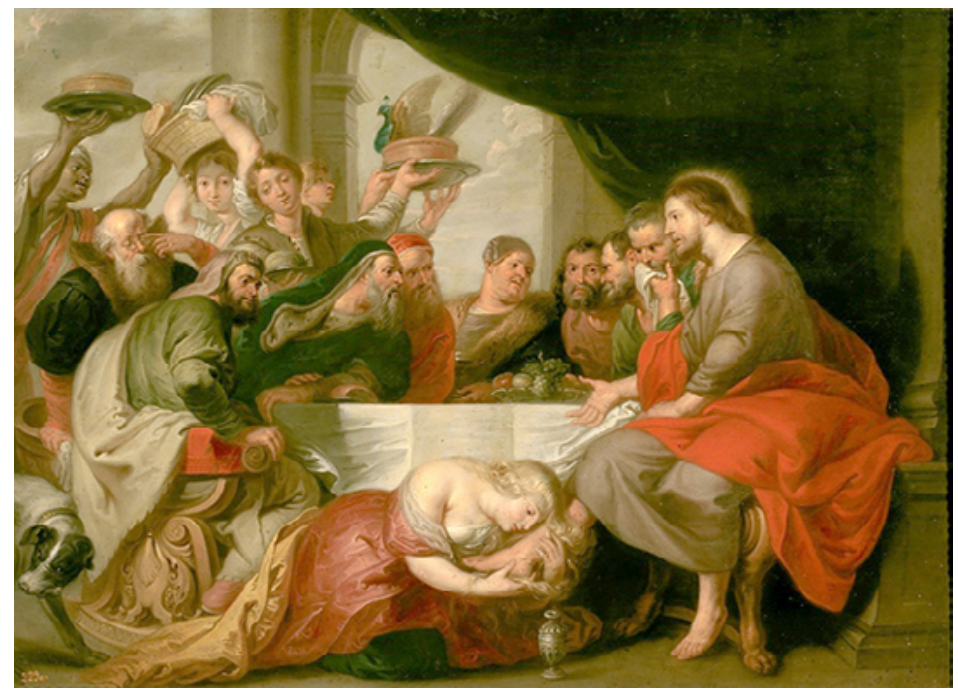

Pieter van Lint. Magdalena en casa del fariseo. Siglo xviI.

Óleo sobre cobre. Museo del Prado, Madrid (España).

a llamarse Siro y Eucaria. Los tres hermanos vivían juntos, pero pronto Magdalena se desentendió de sus obligaciones, entregándose a una vida disoluta ${ }^{24}$. Magdalena era muy rica, y por la vida que llevaba la apodaban «la pecadora». Enterada un día de que el Jesús del que todos hablaban se encontraba en Jerusalén, comiendo en la casa de Simón el leproso, fue y entró en la casa discretamente; al llegar a su lado se tiró al suelo llorando, lavó sus pies con sus lágrimas, los secó con sus cabellos y los perfumó con un riquísimo perfume que había comprado.

Magdalena, con sus lágrimas, lavó los pies del Señor, los limpió con sus cabellos, los ungió con ungüento oloroso y fue la primera que en aquel tiempo de gracia hizo solemne y pública penitencia; ella fue también la que eligió la mejor parte y sentada a la vera de Cristo escuchó atentamente sus palabras; también fue ella quien derramó sobre la cabeza del Señor un tarro de bálsamo perfumado y quien permaneció junto a la cruz de Cristo durante su Pasión, y quien compró los aromas para ungir su cuerpo muerto, y quien se quedó velando su sepulcro cuando los demás discípulos se marcharon; también fue la primera a quien Jesús resucitado se apareció y la encargada por Él de comunicar su resurrección a los demás, convirtiéndose de este modo en apóstola de los apóstoles ${ }^{25}$.

${ }^{24}$ Vorágine, Santiago de la (1989). La Leyenda Dorada, 1. Alianza Forma, Barcelona, p. 383. p. 384 .

25 Vorágine, Santiago de la (1989). La Leyenda Dorada, 1. Alianza Forma, Barcelona, 
Este episodio de la unción de los pies por una mujer en Betania ${ }^{26}$ es una tradición recogida por todos los evangelistas (Mt 26, 6-13; Mc 14, 3-9 y Jn 12, 1-8), pero, salvo Lucas, todos sitúan la acción en Betania. Juan lo hace al principio de la semana, entendiendo que la semana comienza con la entrada triunfal de Jesús en Jerusalén, y sería seis días antes de Pascua. Marcos y Mateo, por el contrario, la sitúan a dos días antes de la Pascua. Para Lucas, la acción no sucede en Betania, y la mujer no es la hermana de Marta y Lázaro, sino una desconocida. Para Mateo y Marcos, por el contrario, no es una pecadora, coincidiendo con Juan en que es una desconocida.

El profesor Antonio Piñero no sabe exactamente dónde situar el episodio, aunque se inclina por la versión de Lucas, situándolo en Jerusalén, cuando Jesús aún no había entrado en la ciudad, inmediatamente antes de la fiesta de los Tabernáculos, que en opinión del historiador judío Flavio Josefo era la fiesta más grande y más santa ${ }^{27}$.

Según Lucas (7, 37-50),

En aquel tiempo, un fariseo rogó a Jesús que comiera con él, y, entrando en la casa del fariseo, se puso a la mesa. Había en la ciudad una mujer pecadora pública, quien al saber que estaba comiendo en casa del fariseo, llevó un frasco de alabastro de perfume, y poniéndose detrás, a los pies de Jesús, comenzó a llorar, y con sus lágrimas le mojaba los pies y con los cabellos de su cabeza se los secaba; besaba sus pies y los ungía con el perfume.

$\mathrm{Al}$ verlo el fariseo que le había invitado, se decía para sí: «Si éste fuera profeta, sabría quién y qué clase de mujer es la que le está tocando, pues es una pecadora». Jesús le respondió: «Simón, tengo algo que decirte». Él dijo: «Di, maestro». «Un acreedor tenía dos deudores: uno debía quinientos denarios y el otro cincuenta. Como no tenían para pagarle, perdonó a los dos. ¿Quién de ellos le amará más?».

Respondió Simón: «Supongo que aquel a quien perdonó más». Él le dijo: «Has juzgado bien», y volviéndose hacia la mujer, dijo a Simón: «¿Ves a esta mujer? Entré en tu casa y no me diste agua para los pies. Ella, en cambio, ha mojado mis pies con lágrimas, y los ha secado con sus cabellos. No me diste el beso. Ella, desde que entró, no ha dejado de besarme los pies. No ungiste mi cabeza con aceite. Ella ha ungido mis pies con perfume. Por eso te digo que quedan perdonados sus muchos pecados, porque ha mostrado mucho amor. A quien poco se le perdona, poco amor muestra».

Y le dijo a ella: «Tus pecados quedan perdonados». Los comensales empezaron a decirse para sí: «¿Quién es éste que hasta perdona los pecados?». Pero Él dijo a la mujer: «Tu fe te ha salvado. Vete en paz».

${ }^{26}$ González Hernando, Irene (2015). «La unción de Cristo en el imaginario medieval y la exégesis sobre la identidad entre María Magdalena, María de Betania y la pecadora anónima». Revista Digital de Iconografía Medieval, vol. viI, n. ${ }^{\circ}$ 14, 2015, pp. 79-81.

${ }_{27}$ Piñero, Antonio (2008). La verdadera historia de la Pasión. Según la Investigación y el Estudio Histórico. Edaf, Madrid, p. 164. 


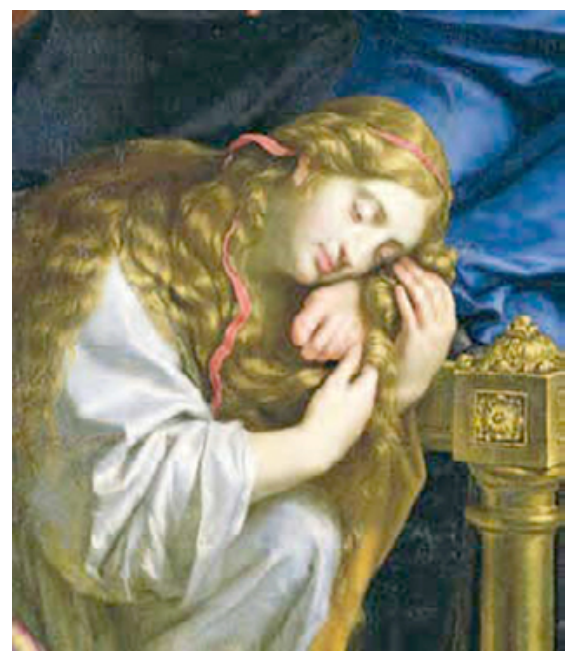

Philippe de Champaigne. Cristo en la casa de Simón el fariseo (det.). (c. 1656). Museo de BB. AA. Nantes (Francia).

Lo cierto es que no se sabe con seguridad quién es la mujer. Para Marcos y Mateo la mujer esparce aceite perfumado sobre la cabeza de Jesús. Juan la identifica con María, la hermana de Lázaro y Marta, y unge los pies, no la cabeza (Jn 12, 3); Lucas sitúa la acción en Galilea y la mujer es una pecadora que así queda libre de sus pecados, echándole a Jesús aceite sobre su cabeza, ungiendo, lavando y besando sus pies (Lc 7, 36). Para Marcos y Mateo es sencillamente una desconocida (Mc 14, 3 y Mt 26, 7).

La religiosa agustina y visionaria alemana Anna Catalina Emmerich ${ }^{28}$ en sus Visiones y Revelaciones, publicadas por primera vez a mediados del siglo XIX, describe el episodio situándolo en Betania y lo protagoniza María Magdalena:

ayer por la tarde, Nuestro Señor tomó su última comida junto con sus amigos, en casa de Simón el Leproso, en Betania, y allí mismo, María Magdalena ungió por última vez con perfume los pies de Jesús. Judas se escandalizó; corrió a Jerusalén y conspiró con los príncipes de los sacerdotes para entregarles a Jesús. Después de la comida, Jesús volvió a casa de Lázaro, mientras algunos de los apóstoles se dirigían a la posada que se halla a la entrada de Betania. Por la noche, Nicodemo acudió de nuevo a casa de Lázaro y tuvo una larga conversación con el Señor; volvió a Jerusalén antes del amanecer, y Lázaro lo acompañó durante un tramo del camino ${ }^{29}$.

${ }^{28}$ Ana Catalina Emmerich (1774-1824) fue una religiosa agustina alemana, cuyas visiones fueron transcritas por Clemente Brentano. Emmerich narra todos los acontecimientos desde el arresto de Jesús hasta su resurrección, y fueron publicadas por vez primera en 1833.

29 Emmerich, Ana Catalina (2004). La amarga Pasión de Cristo. Planeta, Barcelona, p. 7. 
Lo cierto es que las dos Marías más importantes en los relatos evangélicos son María Magdalena (o de Magdala) y María de Betania (a veces identificada con la anterior, y supuestamentela hermana menor de Lázaro y Marta, amigos de Jesús). Hay una clara oposición entre ambas mujeres; ellas son las más cercanas a Jesús como compañeras, de modo que a la de Magdala se la identifica con el arrepentimiento y simboliza la Ley y los profetas del Antiguo Testamento, mientras que la de Betania se caracteriza por el amor libremente escogido, aludiendo al Nuevo Testamento.

Santiago de la Vorágine plantea que el nombre María tiene un triple significado: mar amargo, iluminadora e iluminada; es decir: penitencia, contemplación interior y gloria eterna. Magdalena, por su parte, también tiene tres interpretaciones: culpable, invicta y magnífica ${ }^{30}$.

Pero lo cierto es que, en las ocasiones en las que María Magdalena ha hecho acto de presencia en algún filme que trate sobre la vida de Jesús, normalmente siempre ha tenido un papel secundario, pero nunca ha sido protagonista. En La espada y la cruz (La Spada e la Croce, Carlo Ludovico Bragaglia, 1958), María Magdalena (Ivonne de Carlos) es hermana de Marta y Lázaro, y vive rodeada de lujos. El guion gira en torno al triángulo amoroso entre Cayo Marcelo, María Magdalena y Anás, su amante, papel interpretado por Massimo Serato ${ }^{31}$. En medio de toda esta locura aparece Jesús de Nazaret y María decide cambiar de vida, abandonándolo todo para seguirle.

En los años 80 La última tentación de Cristo (The Last Temptation of Christ, Martín Scorsese, 1988) plantea la disyuntiva de que hubiera ocurrido si Jesús se hubiera casado, primero con María Magdalena, y tras enviudar, contraer segundas nupcias con María de Betania; continúa con el oficio paterno trabajando en una carpintería construyendo cruces y tiene hijos. Es decir, un Jesús más humano que divino que, desoyendo la llamada del Padre, decide vivir como un hombre casado y procrear varios hijos ${ }^{32}$.

En el año 2000, la serie de televisión Los amigos de Jesús. María Magdalena (Gli amici di Gesù. Maria Maddalena, Raffaele Mertes y Elisabetta Marchetti, 2000) cuenta la historia de una mujer a quien su marido Amós, un rico judío, repudia por ser estéril y no poder darle un hijo. Amós la obliga a abandonar su hogar, pero antes de salir recibe la visita de Silvano, precepto de Roma, que la acoge en su casa, y se convierte en su amante. Magdalena (Maria Grazia Cucinotta) sigue de cerca las predicaciones de Juan el Bautista, que anuncia la llegada del Mesías de modo que su amante, sintiéndose traicionado, la entrega a los soldados romanos que la tratan con brutalidad. Sola y despojada de toda dignidad, un día se encuentra con Jesús y decide seguirlo, convirtiéndose en su principal seguidora.

${ }^{30}$ Vorágine, Santiago de la (1989). La Leyenda Dorada, 1. Alianza Forma, Barcelona, pp. 382-383.

31 Calero Ruiz, Clementina (2019). «Muerte y resurrección. La Pasión de Cristo vista por el séptimo arte». Latente, Revista de historia y estética del audiovisual. pp. 16-17.

32 Calero Ruiz, Clementina (2019). «Muerte y resurrección. La Pasión de Cristo vista por el séptimo arte». Latente, Revista de historia y estética del audiovisual. p. 38. 


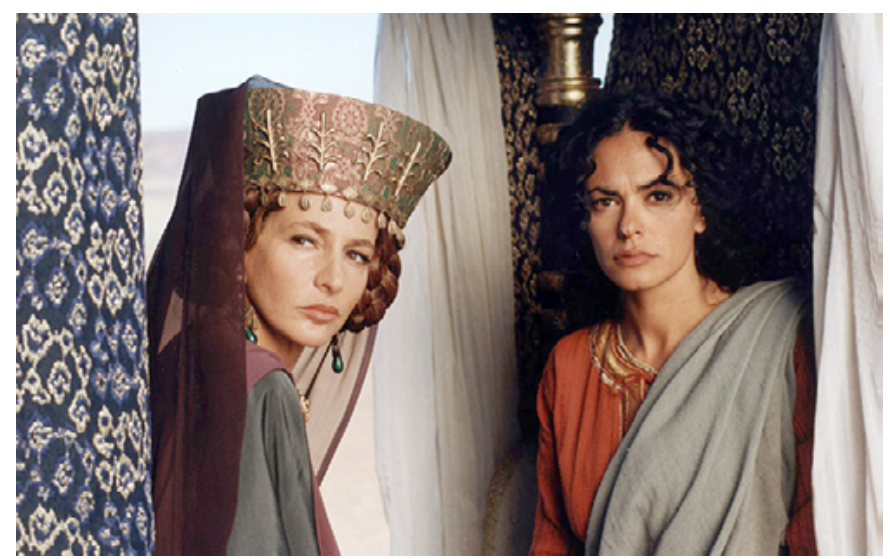

Fotograma de la película Los amigos de Jesús. Maria Magdalena (Gli amici di Gesù. Maria Maddalena, Raffaele Mertes y Elisabetta Marchetti, 2000).

En el año 2005 se estrena Mary (Abel Ferrara, 2005), la historia de tres personas, cuyos destinos se cruzan de modo inesperado tras los atentados del 11-S en Nueva York. Tony (Matthew Modine), un importante director de cine, viaja a Israel con la intención de rodar una película cuyo tema principal es la vida de Jesús de Nazaret, que él mismo protagoniza. Marie Palesi (Juliette Binoche) será María Magdalena, quien para conocer mejor a su protagonista se sumerge en su vida y lo que supuso su presencia acompañando a Jesús desde Galilea hasta Jerusalén. Y finalmente Ted (Forest Whitaker), un periodista ateo, que presenta un programa de televisión, en que el director y la actriz son invitados para hablar del filme. Al acabar el rodaje, Marie se queda en Jerusalén para intentar indagar en la vida de esa mujer, por la que quedó fascinada, y conocer qué de verdad había detrás de su historia. Algunas escenas de la película se basan en los Evangelios gnósticos, no en los canónicos, como hemos comentado en páginas anteriores, por lo que en su estreno fue muy atacada.

Mel Gibson, por su parte, en La Pasion de Cristo (The Passion of the Christ, 2004), siempre presenta a Magdalena (Mónica Bellucci) acompañando a María, la Madre, protagonizando momentos especialmente intensos en escenas tan duras como la de la flagelación y crucifixión a los pies de la cruz ${ }^{33}$. En el primero de los casos, ambas mujeres, desde una estancia contigua, intuyen el suplicio que le están infligiendo a Jesús, empatizando con su dolor. Ese momento tan cruel lo describe la visionaria alemana así:

33 Calero Ruiz, Clementina (2005). «El teatro de las emociones. Trento, Mel Gibson y su Pasión de Cristo». Latente, Revista de historia y estética del audiovisual, p. 108. 


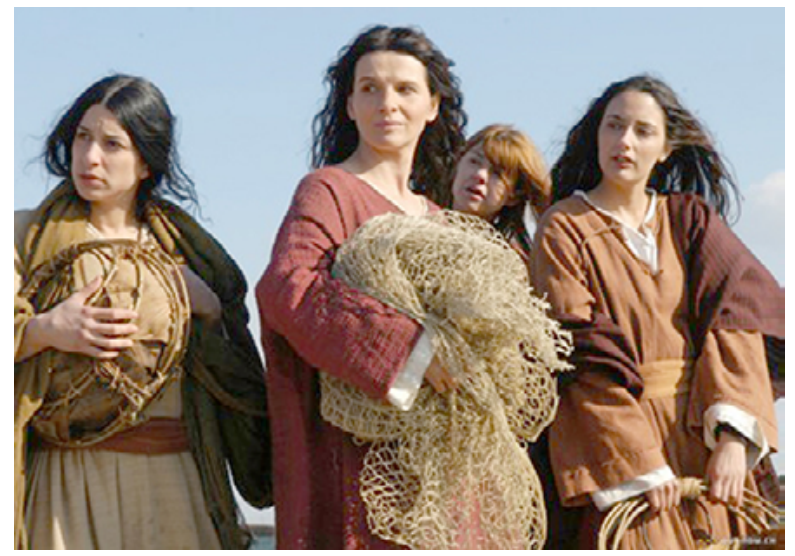

Juliette Binoche como María Magdalena en Mary (Abel Ferrara, 2005).

Magdalena estaba pálida y abatida por el dolor. Tenía los cabellos en desorden bajo su velo. Cuando Jesús, después de la flagelación, cayó al pie de la columna, vi a Claudia Procla, mujer de Pilato, enviar a la Madre de Dios grandes piezas de tela [...]. Habiendo vuelto en sí, María vio a su Hijo, todo desgarrado, conducido por los soldados; Él se limpió los ojos llenos de sangre para mirar a su Madre. Ella extendió las manos hacia Él, y siguió con los ojos las huellas ensangrentadas de sus pies. Habiéndose apartado la muchedumbre, María y Magdalena se acercaron al sitio en donde Jesús había sido azotado. Escondidas por las otras santas mujeres y por otras personas bien intencionadas que las rodeaban, se agacharon cerca de la columna y limpiaron por todas partes la Sangre sagrada de Jesús con los lienzos que Claudia Procla había mandado ${ }^{34}$.

\section{Y respecto al Calvario, Emmerich alega que}

La Santísima Virgen y Magdalena esperaban sentadas al pie de la cruz, a la derecha, entre la cruz de Dimas y la de Jesús; las otras mujeres estaban ocupadas en preparar los pańos, los aromas, el agua, las esponjas y las vasijas [...].

\section{Añadiendo más adelante que}

Magdalena, se hallaba entregada enteramente a su dolor, y nada podía consolarla ni distraerla, ni la presencia de los demás ni ninguna otra consideración ${ }^{35}$.

34 Emmerich, Ana Catalina (2004). La amarga Pasión de Cristo. Planeta, Barcelona, pp. 144-146.

35 Emmerich, Ana Catalina (2004). La amarga Pasión de Cristo. Planeta, Barcelona, p. 212. 


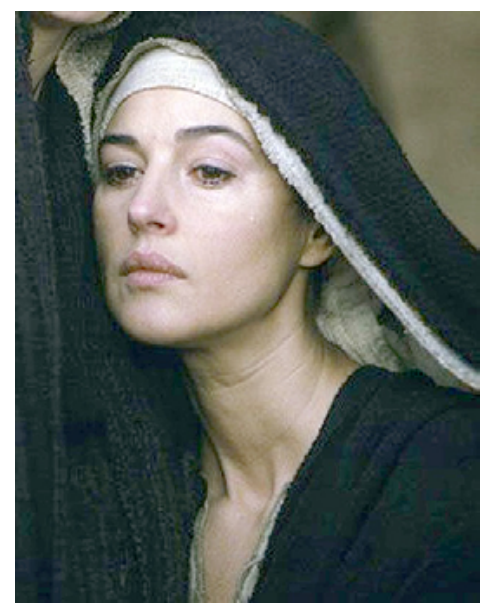

Mónica Bellucci como María Magdalena en La Pasión de Cristo (Mel Gibson, 2004).

En esta ocasión, Magdalena ha abandonado el papel secundario que siempre la ha acompañado, y empieza a convertirse en protagonista de su historia. Pero en el año 2006, el filme El código da Vinci (The da Vinci Code, Ron Howard), le da otro giro al personaje, cuando un catedrático de Simbología Religiosa, experto en símbolos y divinidades femeninas, llamado Robert Langdon (Tom Hanks), se ve inmiscuido en el gran secreto de la descendencia de Jesús, y la búsqueda del Santo Grial, que según la trama de la película era María Magdalena, que había concebido y llevado en su vientre a su hijo. Esos secretos, supuestamente, están ocultos en la obra de Leonardo, de modo que, ayudado por una criptógrafa de la policía (Audrey Tautou), intentan descifrarlos viajando por París, Londres y Escocia, tras la búsqueda de algo que hará que los cimientos de la historia se tambaleen.

Sin embargo, no será hasta el año 2018, que nos encontremos con una película en la que Magdalena es la protagonista absoluta (Mary Magdalene, Garth Davis, 2018). Convertida en una mujer fuerte y dueña de su destino, en el año 33 d.C., cuando Judea estaba controlada por Roma, desafía a su familia para seguir a Jesús como su principal discípula. Esta situación le traerá conflictos con alguno de los apóstoles, especialmente con Pedro, que no ve correcto que el Rabí la haya elegido como guía. En esta ocasión se le ha dado un enfoque diferente a esta mujer calificada como una prostituta redimida por Jesús, para convertirla en una adelantada de su época, con un protagonismo mayor del que siempre se ha creído que tuvo. De hecho fue a ella a quien primero se le apareció Jesús tras la resurrección, encargándole la misión de comunicarlo a los discípulos.

Juan, en su Evangelio (Jn 16, 7-13), es el único que nos dice que Jesús ascendió a los cielos en presencia de María Magdalena en el jardín del sepulcro. Y después de la resurrección, le prohíbe que lo toque, pues todavía no he subido al Padre, pidiéndole que busque a los discípulos y les transmita este mensaje: Voy a subir a mi 


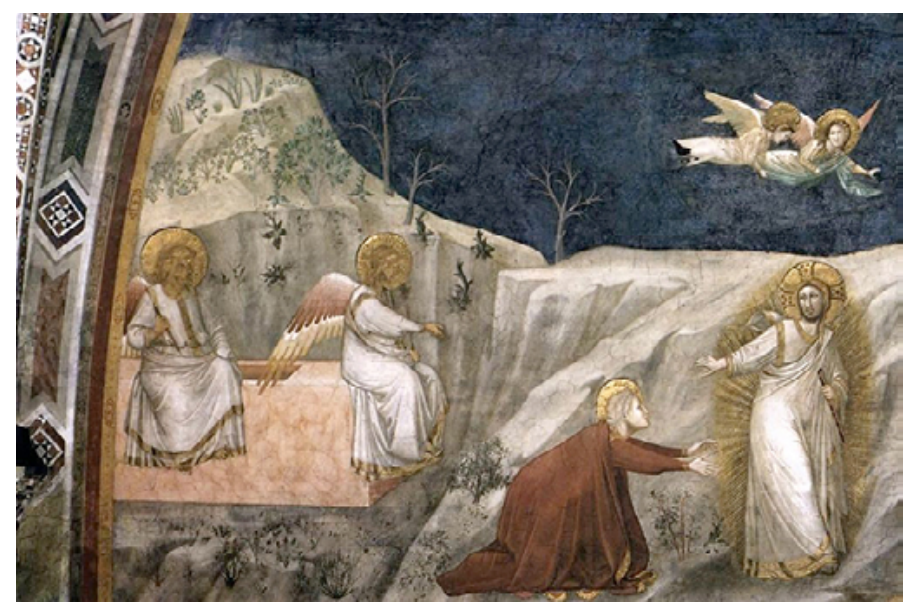

Giotto di Bondone. Escenas de la vida de María Magdalena: Noli me tangere (1302- 1306).

Fresco. Capilla de la Magdalena, Basílica de San Francisco, Asís (Italia).

Padre y a vuestro Padre; a mi Dios, y a vuestro Dios (Jn 20, 17), y ese mismo día, por la tarde, en presencia de los apóstoles, reciben al Espíritu Santo (Jn 20, 22).

Catalina Emmerich, en sus visiones, desmenuza el acontecimiento así:

Magdalena entró en el jardín y se dirigió al sepulcro. Llegaba trastornada por su viaje y su dolor, cubierta de rocío, con el manto caído y sus hombros y largos cabellos sueltos y descubiertos. Como estaba sola, no se atrevió a bajar a la gruta, y se detuvo un instante a la entrada. Se arrodilló para mirar dentro del sepulcro desde allí y, al echar hacia atrás sus cabellos, que le caían sobre la cara, vio dos ángeles vestidos de blanco sentados a ambos extremos del sepulcro, y oyó la voz de uno de ellos que decía: «Mujer ¿por qué lloras?». Ella gritó en medio de su dolor, pues no repetía más que una cosa y no tenía más que un pensamiento al saber que el cuerpo de Jesús no estaba allí: «Se han llevado a mi Señor y no sé dónde lo han puesto». Después de estas palabras, se levantó y se puso a buscar frenéticamente aquí y allá; le parecía que iba a encontrar a Jesús; presentía confusamente que estaba cerca de ella y la aparición de los ángeles no podía distraerla de ese pensamiento. Pareciera que no se diera cuenta de que eran ángeles y no podía pensar más que en Jesús: «Jesús no está allí, ¿¿dónde está Jesús?» La vi moverse de un lado a otro como una persona que ha perdido la razón ${ }^{36}$.

La monja describe con todo lujo de detalles cómo los cabellos le caían por la cara y cómo a diez pasos del sepulcro, en el sitio donde el jardín sube hacia la ciup. 244 .

36 Emmerich, Anna Catalina (2004). La amarga Pasión de Cristo. Planeta, Barcelona, 


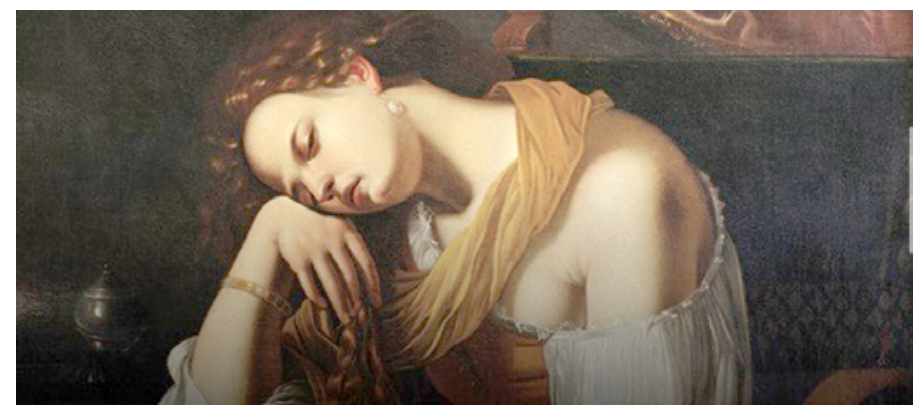

Artemisia Gentileschi. María Magdalena como la melancolía (det). (c. 1625). Museo Soumaya (Ciudad de México).

dad, vio aparecer una figura vestida de blanco, entre los arbustos, a la luz del crepúsculo, y corriendo hacia él oyó que le dirigía estas palabras:

«Mujer, ¿por qué lloras?» Ella creyó que era el jardinero y, en efecto, el que le hablaba tenia una azada en la mano y sobre la cabeza un sombrero ancho que parecía hecho de corteza de árbol. [...] El hombre le hizo una nueva pregunta: «Por qué lloras?» Y entonces ella, en medio de sus lágrimas respondió: «Porque se han llevado a mi Señor y no sé adónde. Si lo has visto, dime donde está y yo iré a por él.» Y volvió a dirigir la vista frenética a su alrededor. Entonces Jesús le dijo con su voz de siempre: «iMagdalena!» Y ella, reconociendo su voz y olvidando crucifixión, muerte y sepultura, como si siguiera vivo, dijo volviéndose de golpe hacia Él: «iRabí!», y se postró de rodillas ante Él, extendiendo sus brazos hacia los pies de Jesús. Más Él, deteniéndola, le dijo: «No me toques, pues aún no he subido hasta mi Padre. Ve a decirles a mis hermanos que subo hacia mi Padre y Vuestro Padre, hacia mi Dios y el Vuestro.» Y desapareción ${ }^{37}$.

Garth Davis, por fin, presenta a Magdalena como una mujer sensible e inteligente, convertida en Mulieres Dignitatem, como la definió el papa Juan Pablo II: la apóstola de los apóstoles; título corroborado posteriormente por el actual papa Francisco, instituyendo su fiesta en el calendario romano, como al resto de los apóstoles, el día 22 de julio.

No obstante, el arte occidental la ha venido representando como penitente, aunque no hay pruebas documentales en los Evangelios que certifiquen que llevara una vida pecaminosa o promiscua. Ya se ha señalado cómo sería, siglos más tarde, que el papa Gregorio la confundió con la mujer pecadora que se tiró a los pies de Jesús y los lavó con sus lágrimas, tratando quizás de desacreditar algunas tradiciones gnósticas disidentes que la veneraban como apóstol de apóstoles. No fue hasta 1969

37 Emmerich, Anna Catalina (2004). La amarga Pasión de Cristo. Planeta, Bercelona, p. 245. 
que el Vaticano separó explícitamente la figura de María Magdalena del personaje de la mujer pecadora ${ }^{38}$.

Desde el pasado 21 de junio de 2021, y bajo el título de María Magdalena, testigo principal, pecadora feminista, el Museo Catharijneconvent, de la ciudad holandesa de Utrecht, repasa las diferentes caras de María Magdalena. Hasta Lady Gaga cae rendida a sus pies, acompañando su música a la exposición, que reúne todo tipo de piezas, incluyendo adaptaciones cinematográficas que tratan especialmente la estrecha relación que existió entre ella y Jesús ${ }^{39}$. En palabras de su comisaria, Lieke Wijnia, su objetivo no es otro que

mostrarla en diferentes tradiciones religiosas, desde el cristianismo oriental al occidental. Ella bendice, tienta, llora, ora, proclama, se arrepiente y hace milagros, se considera una apóstol, pecadora penitente, amante y sensual fémina, testigo de la resurrección, ermitaña, mística, prostituta y autora de milagros, encarnaciones de su persona que reflejaron el espíritu de épocas y formas en las que se consideraba a las mujeres en varios tiempos ${ }^{40}$.

RECIBIDO: 31-5-2021; ACEPTADO: 2-7-2021

38 Arqueología de la Biblia. Parte 2. Nuevo Testamento. Capítulo 2: Arqueología de la vida de Jesús. Los Evangelios de Mateo, Marcos, Lucas y Juan. National Geographic, Edición Especial, p. 84.

39 https://elpais.com/cultura/2021-06-25/las-caras-de-maria-magdalena-de-la-mujer-caida-al-icono-feminista.html [consultado el 10 de julio de 2021].

${ }^{40}$ https://www.elperiodicodearagon.com/cultura/2021/06/24/maria-magdalena-apostol-pecadora-musa-54293118.html [consultado el 10 de julio de 2021]. 


\title{
CANARIAS EN LAS PRIMERAS PELÍCULAS EN COLOR. LAS ISLAS EN EL CATÁLOGO DE LA COMPAÑÍA KINEMACOLOR
}

\author{
Natalia Vías Trujillo
}

\section{RESUMEN}

El sistema británico Kinemacolor fue el primero en alcanzar el éxito comercial en la captura directa del color. Mediante este proceso mecánico-fotográfico, los fotogramas en blanco y negro quedaban impresionados de forma sucesiva a través de dos filtros de color (rojo y verde), y con posterioridad, proyectados a través de luces de los mismos tonos, para producir imágenes en color gracias a la cualidad aditiva del color-luz. El primer catálogo Kinemacolor, publicado en 1913, reunía películas de ficción y documental, entre las que encontramos películas de viajes rodadas alrededor del mundo. España fue uno de los destinos recorridos por los operadores Kinemacolor quienes, entre otros lugares, viajaron a las islas de Tenerife y Gran Canaria, donde rodaron las que posiblemente sean las primeras películas filmadas en color en el Archipiélago.

Palabras clave: historia del cine, cine mudo, películas en color, compañía Kinemacolor, catálogo Kinemacolor, Islas Canarias, travelogues.

\section{THE CANARY ISLANDS IN THE KINEMACOLOR CATALOGUE. THE FIRST COLOR FILMS}

Abstract

The British Kinemacolor was the first direct color capture filming system to achieve commercial success. Through this mechanical-photographic process, successive black and white frames were impressed through two color filters (red and green), and later, projected through the same coloured lights to produce color images taking advantage of the additive nature of light colours. The first Kinemacolor catalogue, published in 1913, included fiction and documentary films. Among this pictures we find several travel films shot around the world. Spain was one of the countries visited by the Kinemacolor camera operators who, among other destinations, traveled to the islands of Tenerife and Gran Canaria, where they filmed which are possibly the first pictures shot in color in the Islands.

Keywords: Film History, Silent Films, Color films, Natural Color Kinematograph Co, Ltd., Kinemacolor Catalogue, Canary Islands, travelogues. 
El anhelo de captar la realidad "tal cual es» ha dado alas a la búsqueda de nuevos avances que contribuyan a la evolución de la fotografía y el cine. Una vez que la técnica cinematográfica logró captar el movimiento, la aspiración de los pioneros se centró en alcanzar la reproducción directa del color y la captura del sonido. El cine desde sus comienzos tuvo siempre color y el sonido, ya durante el periodo silente, estaba presente en las salas de exhibición formando parte de la experiencia cinematográfica.

En el año 2012 la prensa británica se hacía eco de un hallazgo que aportaba un nuevo y decisivo destello al brumoso periodo de los primeros años del cinematógrafo. Un prometedor titular de la BBC rezaba así: «World’s first color film footage viewed for first time»" («El primer metraje en color del mundo visto por primera vez»).

Los conservadores del National Science and Media Museum de Bradford (Inglaterra) descubren en el archivo fílmico de dicha entidad la primera película realizada en color de la historia del cine. La cinta Parrot on Perch and Goldfish in Bowl, rodada en 1902 por el pionero del cine británico Edward Raymond Turner (18731903), presentaba la novedad de haber sido filmada por medio de una cámara que incorporaba filtros en discos rotatorios de tres colores: azul, verde y rojo ${ }^{2}$. El paso del fotograma era inusual para la época, $38 \mathrm{~mm}$ con una perforación a cada lado del $\mathrm{mismo}^{3}$. Cada fotograma en blanco y negro era impresionado por la cámara alternativamente mediante cada uno de los filtros, azul, verde y rojo, que, al unirse al ser proyectados, daban como resultado la imagen en color. Mediante este proceso mecánico fotográfico, la película no tenía que someterse al, por entonces, laborioso proceso de ser coloreada a posteriori utilizando las técnicas de añadido de color a las copias en blanco y negro: el pintado a mano, el virado, el teńido o tintado y las plantillas de color ${ }^{4}$.

En declaraciones al mencionado medio de comunicación británico, Bryony Dixon, conservadora del British Film Institute (BFI), afirmaba: «Pienso que este es un paso decisivo para romper el mito de las viejas películas en blanco y negro. El $80 \%$ de las películas de entre 1890 y 1920 estaban deliberadamente coloreadas ${ }^{5}$.

${ }^{1}$ BBC News, World first colour film footage viewed for first time (12 September 2012), <https:// www.bbc.com/news/uk-england-19557914> (3/7/2020).

${ }^{2}$ En 1897 Hermann Isensee patenta en Berlín el primer procedimiento de captura de imágenes en color con el uso de filtros de color rojo, azul y verde. Turner desarrolla el sistema de Isensee como lo haría Urban posteriormente con el suyo. Timeline of Historical Film Colors. Barbara Flueckiger, Department of Film Studies. University of Zurich, <https://filmcolors.org/timeline-entry/1219/> (25/8/2020).

3 Dato extraído de Bailey, John, ASC. (2012). Two early color tests. American Cinematographer, <https://ascmag.com/> (26/7/2020).

4 Técnicas de coloreado a mano fotograma a fotograma muy en boga desde la década de 1890 hasta mediados de los ańos veinte del siglo xx.

5 Declaraciones contenidas en BBC News, 2012. 
Debido a una leve y perceptible falta de sincronicidad entre las imágenes en movimiento y el color, al ser visionadas hoy día, estas primeras imágenes rodadas por Turner mantienen un cierto halo irreal. En esta primera película el color parece tender a escabullirse, evadirse por momentos del contorno de las figuras, dando a las imágenes cierta apariencia evanescente. Turner capturó para siempre la imagen espectral de sus hijos ${ }^{6}$ jugando en el jardín de la casa familiar en Hounslow, a las afueras de Londres.

Su sistema fotográfico, patentado en 1899 , fue financiado por otro pionero del cine británico, Charles Urban (1867-1942), quien, debido al prematuro fallecimiento de Turner, hereda su invento y lo desarrolla.

Charles Urban, norteamericano afincado en Inglaterra, representa junto al inventor londinense George Albert Smith (1864-1959), impulsores ambos de la escuela de Brighton ${ }^{7}$, dos de las figuras que más decisivamente contribuyeron al desarrollo del cine británico durante la época victoriana ${ }^{8}$.

Ambos exploran la senda entreabierta por Turner y en 1906 patentan el Kinemacolor ${ }^{9}$. Un sistema que se convertirá en monopolio de éxito del cine en color durante los primeros años de la década de los diez, y que lanzarán comercialmente a partir de 1909 a través de su compañía Natural Color Kinematograph Co, Ltd ${ }^{10}$, cuyos estudios establecieron en las ciudades de Brighton, en Inglaterra, y Niza, en Francia.

Este sistema aditivo del color, de captura de las imágenes mediante el sistema Kinemacolor, se basaba en la utilización en la cámara cinematográfica con dos filtros rotatorios de color rojo y verde que incidían sobre un negativo blanco y negro. En el momento de la exhibición, el aparato proyector, que permitía tanto la proyección en color como en blanco y negro, también debía de incluir ambos filtros para la reproducción del color. La película se proyectaba a 32 fotogramas por

${ }^{6}$ Alfred Raymond Turner, Agnes May Turner y Wilfred Sidney Turner.

7 La Escuela de Brighton (Brighton School), denominada así por el historiador cinematográfico francés George Sadoul, englobaba a un grupo de cineastas quienes, entre 1896 y 1910, dan un impulso decisivo a la técnica y narrativa cinematográfica británica. A ella pertenecían fotógrafos y cineastas como George Albert Smith, James Williamson, Charles Urban y William Friese-Greene.

${ }^{8}$ Cuando hablamos de cine de la época victoriana nos referimos al periodo comprendido entre la presentación del cinematógrafo Lumière en París en 1895 y el fallecimiento de la reina Victoria en 1901. En Who's Who at the Victorian Cinema, los historiadores Stephen Herbert y Luke McKernan lo retrotraen hasta la década de 1870, ya que, según ambos historiadores, el comienzo del cine no puede datarse en una fecha específica, $<$ https://www.victorian-cinema.net/> (10/7/2020).

${ }^{9}$ El 26 de febrero de 1908 se celebra en el Palace Theatre of Varieties la primera proyección pública en Londres del sistema Kinemacolor. El 11 de diciembre de 1909 se presenta en el Concert Room del Madison Square Garden en Nueva York. La presentación estuvo a cargo de Albert Smith y Charles Urban. A Visit to the Seaside, rodada por George Albert Smith en 1908 y de 8 minutos de duración, supuso el primer éxito para la compañía.

10 La sede británica de la Compañía estaba ubicada en Kinemacolor Building, 80-82. Wardour Street. London, W. 
segundo, en lugar de la velocidad habitual de 16 fotogramas por segundo ${ }^{11}$. El sistema era explicado con estas palabras por la propia Compañía ${ }^{12}$ :

For a proper realization of the astounding advance made by Kinemacolor in the art of the camera, it must be clearly emphasized that the colors obtained are due to the agency of «light only». No painting, handwork, stencil work or similar devices are used. The colors are, as it were, lying latent in the photographic picture, and are brought into visibility at the moment of exhibition (Kinemacolor Catalogue: 1913: 5).

(Para darse realmente cuenta del impresionante avance que supone el sistema Kinemacolor en el arte de la cinematografía hay que tener muy presente que los colores son obtenidos solamente a través de la luz. No hay pintura, trabajo manual, plantillas, ni otro recurso similar. Los colores están latentes en el negativo fotográfico y se hacen visibles en el momento de la proyección).

Bajo promesa de la captura real de todos los «asombrosos y maravillosos colores de la naturaleza $»^{13}$, el Kinemacolor presentaba al público de la década un variado programa de películas: largometrajes y cortometrajes de ficción, documentales históricos, de naturaleza y de viajes ${ }^{14}$. Estos últimos, denominados travelogues, rodados por los operadores de Kinemacolor alrededor del mundo ${ }^{15}$, eran exhibidos desde mediados de los años diez ante concurridos auditorios. Las sesiones de exhibición de los travelogues eran habitualmente programadas para ser acompañadas de conferencias (lectures) que hacían las veces de explicación a las imágenes, al tiempo que amenizaban la proyección de las «vistas» de aquellos lugares lejanos y exóticos, soñados e inaccesibles para la mayoría de la población.

En 1912, la prensa cinematográfica The Moving Picture News se hacía eco en una breve reseña de la celebración en Estados Unidos de una de estas sesiones cinematográficas. Un programa muy especial, de gran potencia narrativa y presentado mediante el novedoso sistema del Kinemacolor. «El programa ofrecido esta semana -señalaba la publicación- es probablemente el más memorable de los exhibidos

${ }_{11}$ Debido a que pasaba por el proyector un fotograma a través del filtro rojo y otro a través del verde. El tamaño del fotograma y su perforación era el estándar para la época.

${ }_{12}$ Su funcionamiento fue presentado y explicado por Charles Urban y Albert Smith a científicos y fotógrafos reunidos en la Royal Society of Arts (RSA) de Londres en 1908.

13 «Kinemacolor presents all the gracious and gorgeous tints of nature» extracto del Globe newspaper, London, recogido por el catálogo en su página 105 para publicitar el sistema.

${ }_{14}$ El catálogo Kinemacolor incluye en su índice de materias (pp. 313 a 318) las siguientes: Travel and Scenic (Viajes y vistas); Naval and Military (Naval y Militar); Drama and Comedy (Drama y Comedia); State Ceremonies (Ceremonias de Estado); Natural History-Scientific and Botanical (Historia Natural-Científica y Botánica); Trick Subjects (Trucajes); Sport (Deportes); Miscellaneuos (Miscelánea); Royal Visit to India (Visita Real a la India). Además de añadir un índice con el listado de las ilustraciones contenidas en el catálogo indicando su página correspondiente.

${ }^{15}$ Los operadores de la compañía Kinemacolor, entre ellos el fotógrafo John McKenzie, recorrieron Europa, Argelia, India, Egipto, Sudán, Canadá, Nueva Zelanda, Estados Unidos, Australia y Japón. 
hasta ahora por Kinemacolor» ${ }^{16}$. El público norteamericano tuvo oportunidad de admirarse ante las imágenes de una gran tormenta desatada en el mar y cuyas olas rompían con violencia en la costa de la isla de Tenerife ${ }^{17}$. Quienes asistieron a dicha sesión fueron testigos de la proyección de una tormenta fotografiada en plena furia devastadora ${ }^{18}$, lo que para el catálogo significaba «seguramente un triunfo del arte cinematográfico» y que se mostraba ante sus ojos en sus "colores naturales». Dichas imágenes fueron captadas por los operadores de Kinemacolor gracias a un sistema que permitía al espectador disfrutar de una experiencia cinematográfica más real, más vívida y absolutamente novedosa para un público que recogía con admiración (y bastante naturalidad) el devenir de los extraordinarios y vertiginosos avances técnicos que se estaban produciendo desde mediados del siglo XIX. En palabras del historiador y conservador de la British Library, Luke McKernan: «El Kinemacolor fue la maravilla de su época» (McKernan, 2017: 32).

The Great Storm at Teneriffe integraba, junto a otras películas rodadas alrededor del mundo, el primer catálogo Kinemacolor publicado en 1913 por la compañía británica The Natural Color Kinematograph Co., Ltd. Bajo el título Animated Scenes in Their Actual Colors ("Escenas animadas en sus colores reales») el catálogo se conserva, y se encuentra disponible para su consulta, gracias a la McGill University Library de Montreal (Canadá) ${ }^{19}$.

Los catálogos de ventas de estas grandes compañías eran ofrecidos a las empresas de exhibición que se hacían con los derechos de las patentes para su explotación comercial. Los operadores de Kinemacolor añadían continuamente nuevo material cinematográfico a sus catálogos y las películas eran exhibidas en las salas Kinemacolor de medio mundo. Como el mismo catálogo señala en una nota aclaratoria en su página 14, el número de registro de las películas ofrecidas en él guarda relación con el orden de llegada de los negativos que se recibían fruto del trabajo de los operadores y que progresivamente iban añadiéndose y completando el catálogo. Por lo tanto, a través del estudio de las características de las películas que se

16 The Moving Picture News, volume vi, n. ${ }^{\circ}$ 15, October 12, 1912, Something about Kinemacolor Releases, p. 26. En la hemeroteca digital: Latern, search, visualize $\&$ explore the media history digital Library, <https://lantern.mediahist.org/> (18/6/2020).

${ }_{17}$ Desde finales del siglo XIX, las películas rodadas por, entre otros, Robert Paul (18691943) o Birt Acres (1854-1918), que captaban las olas del mar rompiendo contra la costa, fueron las más celebradas por el público victoriano. Las imágenes del mar, sin trucajes y de gran potencia visual, alcanzaban un gran poder de fascinación para el espectador decimonónico. Rough Sea at Dover, rodada en 1895 por Birt Acres, es unas de las películas británicas más antiguas conservadas.

${ }^{18}$ Se detalla en el catálogo como los operadores fueron testigos de la devastación que ocasionó la tormenta en Tenerife y observaron el casco medio sumergido del buque S.S. Tillus, que encalló en la costa debido a la tormenta.

${ }^{19}$ Catalogue of Kinemacolor Film Subjects: Animated Scenes in Their Actual Colors. The Natural Color. Kinematograph. Co, Ltd, London, 1913. Digitalizado por McGill University Library, Toronto (Canadá) el 25 de octubre de 2017. Título de la cubierta: Kinemacolor Film Catalogue 1912-1913. Consta de 318 páginas, 32 páginas con láminas de ilustraciones en color (64 ilustraciones $\times 24 \mathrm{~cm}$ ). Consultar en $<$ https://archive.org/ $><$ https://archive.org/details/McGillLibrary-rbsc catalogue-kinemacolor_ColgateIXNaturalColor-17612/mode/2up $>$. 
encuentran recogidas en el mismo, podríamos estudiar el interesante desarrollo del propio sistema Kinemacolor, que denota un dominio progresivo de la técnica del color y del lenguaje cinematográfico. Esto se pone de manifiesto cuando establecemos la comparativa entre las primeras películas que se ofrecen en el catálogo, de contenidos más costumbristas, como la primera cinta que lo integra: $A$ Visit to the Seaside (n. ${ }^{\circ} 101,1.035$ feet, páginas 16 y 17 del catálogo), una "vista» rodada en la costa inglesa de Brighton, que se circunscribe al apunte de ciertos detalles del paisaje y en describir las escenas de un plácido día de estancia de unos niños en la costa, de los que el catálogo se vanagloriaba de haber captado «tal cual se ven en la naturaleza»; y el contenido de otras películas más ambiciosas como las que los operadores Kinemacolor rodaron en las ceremonias de Estado. Entre estas últimas se incluye el extraordinario documental de Urban The Coronation Durbar at Delhi, December 12th $1911^{20}$ (n. ${ }^{\circ}$ 507, 3.240 feet, páginas 295 a 299 del Catálogo), una de las películas sobre el subcontinente indio que aparecen recogidas bajo el título The Royal Visit to India 1911-1912, y que fueron rodadas durante el viaje de estado del Rey Jorge V de Inglaterra (1865-1935) y la reina Mary of Teck (1867-1953) entre el 2 de diciembre de 1911 y el 8 de enero de 1912, en el que visitaron las ciudades de Bombay, Delhi y Calcuta (pp. 280 a 310 del catálogo ${ }^{21}$.

El periódico The Times recogía la noticia de la partida de Charles Urban, acompañado de siete de sus operadores, hacia el país del Ganges. Urban fue designado por el propio monarca para llevar a cabo el rodaje de las fastuosas ceremonias reales $^{22}$. La repercusión de los documentales rodados por Urban y su equipo quedó reflejada en algunos de los periódicos de más prestigio de Gran Bretaña: The Times, Sunday Times, Financial News, Telegraph, Daily News y recogidos, como medio de publicitar las películas, por el catálogo en sus páginas 310, 311 y 312 bajo el título Press notices relating to the series... With our King and Queen through India.

Celebradas fueron también las películas que bajo el título The Egyptian Series rodaron los operadores Kinemacolor en Egipto ${ }^{23}$. Esta serie de documentales travelogues que recorrían el país del Nilo de norte a sur con una finalidad -según apunta el propio catálogo- educativa, y para los que la compañía estuvo asesorada por repre-

${ }^{20} \mathrm{Su}$ estreno tuvo lugar en Londres el 2 de febrero de 1912 en el teatro de la Scala (Scala Theatre). El teatro fue inaugurado en 1904. Reconvertido en cine, permaneció desde 1911 a 1918 bajo la gerencia de Charles Urban.

${ }^{21}$ Otras compañías se desplazaron a la India a rodar las ceremonias reales: The Great Coronation Durbar, Delhi 1911 (British Pathé, blanco y negro); Delhi Durbar (1911) (blanco y negro), incluidos en la colección Exploring India on Film 1899-1947, British Film Institute. Algunas de las películas conservadas se encuentran en la Cineteca de Bolonia, el archivo Russian State Documentary Film \& Photo Archive, Krasnogorsk, Russia. Consultar $<\underline{\text { https://www.charlesurban.com/ }}$ films_kinemacolor.html>.

22 The Times, November 16, 1911, «The Durbar in Kinemacolor», p. 11, <https://www. thetimes.co.uk/> (30/7/2020).

${ }^{23}$ La serie sobre Egipto está contenida en las páginas 197 a 217 del catálogo. 
sentantes de la sociedad británica de viajes Thomas Cook \& Son ${ }^{24}$, mostraban al espectador esta «maravillosa y misteriosa tierra». Los operadores de la compañía, acompañando el trazado del río Nilo, que fotografiaron de forma destacada en los atardeceres ${ }^{25}$, comenzaron un viaje de tres meses de duración, en el bajo Egipto, en el canal de Suez y la ciudad de Alejandría y viajando al sur, visitaron Assuán, Luxor y Karnak, llegaron a Nubia y la segunda catarata para finalizar el recorrido en Jartum, la legendaria capital de Sudán, donde el Nilo blanco se encuentra con el Nilo azul26. El catálogo de la compañía The Natural Color Kinematograph. Co, Ltd. 1913, bajo patente Urban-Smith, reúne asimismo diversos travelogues rodados en países tan lejanos entre sí como Argelia, Estados Unidos, Canadá, Bélgica, Italia, Gran Bretaña o Constantinopla (actual Estambul) cuyo índice las engloba bajo el subtítulo Travel and Scenic ${ }^{27}$ y en el que también encontramos recogidas las películas rodadas por Kinemacolor en las Islas Canarias.

Las películas que constan en el catálogo Kinemacolor como rodadas en Canarias son las siguientes:

N. 220 The Great Storm at Teneriffe. Canary Islands $\left(740 \mathrm{feet}^{28}\right)$.

(Página del catálogo :104)

N. 222 Scenes in Santa Cruz, Teneriffe (By Courtesy of the Union-Castle Steamship Company) (850 feet).

Synopsis:

1. Teneriffe.

2. The Union-Castle Steamship.

3. A Pinacce.

4. Taking Observations.

5. A Small Boat.

6. General Views.

7. A Rowing Boat.

8. Santa Cruz: Scenes on the Quay.

9. Boys Paddling.

10. A Rainbow.

11. Street Scenes.

(Páginas del catálogo: 104 y105)

${ }^{24}$ Thomas Cook \& Son fue una compañía británica de viajes fundada por Thomas Cook (1808-1892) en el año 1841 en Leicester, Inglaterra.

${ }^{25}$ Las imágenes de todos los atardeceres rodados en Egipto fueron recogidas en la película titulada Sunsets in Egypt (n. ${ }^{\circ} 378,485$ feet), páginas 216 y 217 del catálogo.

${ }^{26}$ En los fondos del British Film Institute y de la Cineteca de Bolonia se conservan algunas de estas películas rodadas en Egipto.

27 Las películas rodadas en las Islas Canarias contenidas en el apartado Travel and Scenic abarcan las páginas 104 a 110 del catálogo.

${ }^{28}$ La longitud del celuloide está señalada en pies (feet). 
N. ${ }^{\circ} 223$ San Andres and La Orotava, Teneriffe (By Courtesy of the Union-Castle Steamship Company) (710 feet).

Synopsis:

1. San Andres

2. A General Panorama.

3. The Town.

4. A Curious Structure.

5. Island Scenes.

6. A Group of Natives.

7. A Palm Bordered Road.

8. A Rainbow.

(Página del catálogo: 106)

N. 224 Cave Dwellers of Atalaya. Grand Canary (700 feet).

(Páginas del catálogo: 107 y 108)

N. ${ }^{\circ} 225$ On a Banana Plantation (915 feet)

Synopsis:

1. A Plantation of Young Palms.

2. The Bunches of Young Fruit.

3. Bunches Ready for Cutting.

4. Large Bunch of Bananas.

5. Packing the Fruit.

6. Women Workers.

7. Packing the Bunches.

8. A Crate of Fruit ${ }^{29}$.

9. A Van Loaded.

10. The Employees.

11. Loading the Steamers.

12. Two Youthful Natives.

13. Monkey Eating a Banana.

(Páginas del catálogo: 108 y109)

N. 226 A Tram Ride through Las Palmas (280 feet).

(Página del catálogo: 109)

${ }^{29}$ En este apartado el catálogo relata las imágenes de la preparación de la fruta lista para su exportación por los Sres. Lyffe, los exportadores, explica el catálogo, más importantes de plátanos en las islas. 
N. 227 Scenes at Las Palmas. Gran Canary (1060 feet).

Synopsis:

1. Arrival at Grand Canary.

2. Deep Sea Divers.

3. Panorama of Las Palmas.

4. Street Scenes.

5. Local Types.

6. Spanish Soldiers.

7. Boat-Building.

8. Merchants and their Wares.

9. Ploughing by Oxen.

10. Beach Scenes.

(Página del catálogo: 110)

La compañía señalaba a The Great Storm at Teneriffe como un «soberbio modelo de fotografía marina y un excepcional ejemplo de la cualidad translúcida del agua» (Kinemacolor Catalogue, 1913: 104). El catálogo Kinemacolor destacaba asimismo el interés y la belleza de las películas rodadas por sus operadores en Tenerife y Gran Canaria. Incluyendo incluso algún detalle sobre la forma en que las imágenes fueron rodadas, el catálogo describía con detalle el contenido de cada «vista». Las imágenes comprendidas en la película A Tram Ride Through Las Palmas fueron tomadas en la parte trasera de un tranvía en movimiento, con lo que «las curiosas edificaciones y los vehículos que pasaban eran de pleno interés» (Kinemacolor Catalogue, 1913: 109).

Es conocida la fascinación de los pioneros por el movimiento de los trenes y tranvías. En el propio viaje en tren, el paisaje en movimiento enmarcado por la ventanilla (una suerte de encuadre, de límite físico entre nuestra mirada y el objeto de la misma) nos presenta un simulacro de experiencia cinematográfica. Desde los inicios del cinematógrafo, los operadores colocaban sus pesadas cámaras en tranvías, automóviles, embarcaciones, globos aerostáticos, trineos, e incluso, como hizo el propio Alexandre Promio (1868-1926), operador de Lumière, sobre una góndola ${ }^{30}$, a fin de que las imágenes se movieran, «viajaran» libremente, captando un movimiento continuo. Este género de películas, denominado muy acertadamente Phantom Ride o Panoramas, fascinaba al público británico y norteamericano de finales del xix. Gracias a esta nueva perspectiva dinámica, el espectador era testigo del mundo que se movía a su alrededor, la vida que fluía a su misma velocidad y, en el caso del tranvía, casi a la altura de sus ojos.

La experiencia cinematográfica a través de la evolución de la técnica tendería progresivamente a una forma de expresión más realista. Se acercaría a lo que el teórico galo André Bazin (1918-1958) denominaría el «realismo integral». En pala-

${ }^{30}$ Panorama du Grand Canal pris d'un bateau (Alexandre Promio, 1896). 
bras del propio Bazin, a una «recreación del mundo a su imagen, una imagen sobre la que no pesaría la hipoteca de la libertad de interpretación del artista ni la irreversibilidad del tiempo» (Bazin, 2004: 37).

Esta aspiración de los cineastas e inventores de los orígenes daba apoyo a la compañía Kinemacolor para publicitar sus películas:

Only by Kinemacolor can full justice be done to panoramic and scenic subjects, because the system is the only one which provides the realistic qualities necessary to their full and adequate treatment. Those pictures secured by the Urban-Smith process from a railway engine platform, from an aeroplano, a torpedo boat, or any other swiftly-moving conveyance, furnish absolutely faithful reproductions of the actual scenes, and lend practically the true sense of motion. Thus presented, the brilliantly illuminated Kinemacolor pictures are pictures no longer, but realities which afford to the comfortably-seated audience the sensation of viewing the actual scenes through a window. (Kinemacolor Catalogue, 1913: 9).

(Solamente con Kinemacolor se puede hacer justicia a las vistas y paisajes, porque el sistema es el único que provee de las cualidades realistas necesarias para su adecuado trato. Estas imágenes garantizadas por el proceso Urban-Smith rodadas desde una plataforma de la máquina de una locomotora, un aeroplano o un barco lanzatorpedos o cualquier otro transporte en movimiento, reproduce con absoluta fidelidad las escenas reales y provee de la verdadera sensación de movimiento. Así presentado, las brillantemente iluminadas imágenes Kinemacolor ya no son imágenes, sino realidades que ofrecen a un público confortablemente sentado, una sensación de ver escenas reales a través de una ventana).

En el catálogo Kinemacolor no solo se da algún detalle de cómo se tomaban las imágenes, también de la calidad o las características de la imagen en sí. En la película Scenes at Las Palmas, Gran Canary, el catálogo aprecia, en la toma de una panorámica sobre la ciudad, su destacable calidad "estereoscópica», es decir, la gran profundidad conseguida en esta imagen por los operadores Kinemacolor.

Si el catálogo abría su oferta de películas rodadas en Canarias con la mencionada gran tormenta en la costa de Tenerife, este ofrecía para cerrar las películas disponibles sobre las islas, bajo el subtítulo Beach Scenes, algunas escenas rodadas en una playa de Gran Canaria. Una escena que, al leer su descripción en el catálogo, parece casi idílica: las vistas de un mar en calma y la imagen de unos lugareños cargando con arena de la playa los cestos que porta un burrito. Además, la imagen de unas mujeres que rompen piedras en la orilla para hacer un sendero evidencian, según el texto del catálogo, el atraso de las islas debido al duro trabajo manual que realizaban las mujeres tanto a orillas del mar como la dura faena en las plantaciones de plántanos.

Estas imágenes del mar, las embarcaciones y el trabajo de los estibadores en el puerto están siempre presentes aunque también los operadores Kinemacolor captaron la vida de los habitantes de las ciudades y pueblos de Tenerife (Santa Cruz, San Andrés, La Orotava) y Gran Canaria (La Atalaya, Las Palmas).

Entre los siete títulos sobre las islas que integran este catálogo encontramos muchos de los valores paisajísticos que las han hecho desde siempre enormemente 
atractivas tanto para los cineastas como para los fotógrafos de todas partes del mundo: las tonalidades de las coladas de lava, el mar y el cielo límpido de las islas, la luz del alba y el crepúsculo, el verde de las extensiones de cultivo y de los valles, la perfecta simbiosis de las gentes y la naturaleza y los paisajes de gran carga telúrica admirados por ojos foráneos. Así, el catálogo remarca los maravillosos contrastes de color poniendo énfasis en los tonos del mar y el cielo, de los acantilados y los valles. ¿Estamos en definitiva ante las primeras películas rodadas en color en el Archipiélago?

Dada la temprana fecha de su producción podríamos responder afirmativamente.

En la década de los años diez en Canarias el color estaba únicamente en los ojos de los pintores y las lentes de los fotógrafos. Debemos esperar hasta una década posterior para encontrar algunas de las películas más importantes de la historia del cine en Canarias que, rodadas en blanco y negro, fueron tintadas o teñidas en color: Tenerife (José González Rivero, 1922), Canarias (José González Rivero, 1923), El ladrón de los guantes blancos (José González Rivero, Romualdo García de Paredes, 1926) y La hija del Mestre (Carlos Luis Monzón, 1927) ${ }^{31}$.

La primera referencia que se data en el Catálogo de Rodajes en Canarias (1896-1950) de una película rodada en color en las islas es West Africa, Canaries, Madeira $^{32}$, un amateur travelogues de 1938. Película que fue rodada en $16 \mathrm{~mm}$, probablemente mediante el sistema de color Kodachrome ${ }^{33}$, por el operador J.N. Jeneid durante su estancia en Tenerife en un viaje organizado por la compañía británica Thomas Cook (Thomas Cook \& Son., Ltd.).

Por tanto, estas películas rodadas ya en la temprana década de los diez por la compañía Kinemacolor fueron muy probablemente las primeras rodadas en color en las Islas Canarias.

Además de las imágenes de las islas, se ofrecían en el catálogo películas documental o "vistas» rodadas en las ciudades españolas de Sevilla, Granada, Toledo y Madrid. Son las siguientes:

Seville at Carnival Time (n. ${ }^{\circ}$ 269, 460 feet, página 144 del catálogo).

H.M The King of Spain ${ }^{34}$. Reviewing recruits and regulars at Madrid, April 30th 1911 (n. ${ }^{\circ} 267,880$ feet, página 147).

Views of Old Toledo, Spain (n. ${ }^{\circ} 385,1035$ feet, páginas 221 y 222).

31 Información obtenida del Catálogo de Rodajes en Canarias (1896-1950), 2004.

32 Ibid, Catálogo de Rodajes en Canarias. Películas no profesionales extranjeras rodadas en Canarias, p. 221.

${ }_{33}$ Dato incluido en Colonial Film Catalogue, Moving images of the British Empire. The Colonial Film website is funded by the Arts and Humanities Research Council and features films from the British Film Institute, the Imperial War Museum, and the British Empire and Commonwealth Museum, <http://www.colonialfilm.org.uk/> (15/8/2020).

34 El documento muestra al rey Alfonso XIII (1886-1941) acompañado de la reina consorte Victoria Eugenia de Battenberg (1887-1969) pasando revista a las tropas en la ciudad de Madrid. 
Sunny Spain. Seville, Granada and Alhambra (n. ${ }^{\circ} 399,1225$ feet, páginas 222 y 223). Spanish Bull Fight at Madrid (n. ${ }^{\circ} 384,1015$ feet, páginas 223 y 224).

En Madrid, el 7 de mayo de 1915 fue presentado por primera vez el sistema Kinemacolor en el cinematógrafo Príncipe Alfonso ${ }^{35}$, el programa consistió en Procesión de elefantes en Calcuta y Maniobras de la escuadra inglesa ${ }^{36}$, películas que obtuvieron una gran acogida entre el público asistente a tan reseñable acontecimiento ${ }^{37}$. Unos años antes, en 1911, la revista ilustrada Alrededor del mundo dedicaba uno de sus artículos al sistema Kinemacolor destacando lo siguiente: «El Kinemacolor es la última palabra en materia cinematográfica, porque las películas tienen los colores de la realidad sin subterfugio alguno y sin recurrir a ninguno de los medios artificiales empleados para colorear, a mano o a máquina, las cintas en blanco y negro, como hasta ahora se venía haciendo ${ }^{38}$. El Kinemacolor causó gran impacto entre el público madrileño que asistía a las proyecciones diarias de este novedoso sistema publicitado como «rival de la naturaleza».

La noticia del estreno mundial del sistema Kinemacolor llega muy pronto a las Islas Canarias. En el mes de julio de 1911 el Diario de Las Palmas ${ }^{39}$ reproduce la reseña publicada tan solo unos días antes por la revista madrileña Alrededor del mundo.

Después de varios años de éxito comercial (entre 1908 y 1915), el sistema Kinemacolor pierde fuerza, resulta extremadamente gravoso de mantener para la compañía, que se encontraba además en dura pugna con el sistema Technicolor ${ }^{40}$. Este último acabará monopolizando desde los años veinte el color en la industria cinematográfica. Otros avances ocuparán el lugar del primitivo sistema Kinemacolor en la historia del cine; un sistema que fue revolucionario, de gran sencillez técnica y destreza imaginativa, que supuso un enorme empuje para los pioneros que trabajaron con dedicación para lograr hacer evolucionar el tratamiento del color en el cine e hizo avanzar de forma extraordinaria a la industria cinematográfica. En palabras

35 El Teatro Príncipe Alfonso fue inaugurado el 7 de mayo de 1863 y demolido en 1898. Fue obra del prestigioso arquitecto José María Guallart y Sánchez.

${ }^{36}$ El programa también lo integraba la película Industrias de Ceilán y un cortometraje de asunto dramático. Dato que se incluye en el blog Sr. Feliu, "Documentitos de un indocumentado», El Kinemacolor en España, <http://documentitosdeunindocumentado.blogspot.com/2018/09/el-kinemacolor-en-espana.html $>\overline{(21 / 8 / 2020) \text {. }}$

${ }^{37}$ También fue recogida la noticia del Kinemacolor en $A B C$ el 8 de mayo de 1915, p. 22 y El Pais el 9 de mayo de 1915, p. 3 entre otras publicaciones de la época $<$ http://hemerotecadigital. bne.es/> (16/8/2020).

${ }^{38}$ Alrededor del mundo, 12 de julio de 1911, «El Kinemacolor. Una maravilla cinematográfica", p.19. Biblioteca Nacional de España. Hemeroteca Digital $<$ http://hemerotecadigital.bne.es/ issue.vm?id=0001881138\&page=19\&search=kinemacolor\&lang=es $>(8 / 7 / 2020)$.

39 Diario de Las Palmas, 24 Julio 1911, «Kinemacolor. Una maravilla cinematográfica», p. 2.

40 El sistema Technicolor se presenta en 1922 y se implanta en la industria hasta entrada la década de los cincuenta. Dato extraído de Timeline of Historical Film Colors, <https://filmcolors. org/> (24/7/2020). 
del historiador Luke McKernan: «Todas las películas son fascinantes por su tenue, sobrenatural color y destacables por su estudiado valor artístico» ${ }^{41}$.

A partir de entonces, el recuerdo de las películas Kinemacolor se diluye en el tiempo y en la memoria de espectadores y especialistas hasta que, llegada la década de los ochenta, el técnico de un archivo regional de Italia deposita en la Cineteca de Bolonia una valiosa colección de nitratos. Los veintitrés títulos Kinemacolor que componen esta colección de Bolonia fueron restaurados y se encuentran actualmente conservados en los fondos de dicha entidad ${ }^{42}$.

En 2017 la Cineteca de Bolonia a través de Il Cinema Ritrovato presentó, en el Festival que se celebra cada año en la ciudad italiana, un programa de películas Kinemacolor conservadas en los fondos de su archivo fílmico, organizado en colaboración de diversos organismos como el Bristish Film Institute, EYE-Instituto de cine de Ámsterdam y los fondos de la colección John E. Allen de Estados Unidos. Además de la celebración de este programa especial, la Cineteca de Bolonia editó la colección Kinemacolor e altre magie, diez títulos Kinemacolor rodados entre 1907 y 1912, restauradas por L'immagine Ritrovata, contenidos en dos DVD y acompañados de un breve catálogo. La colección incluía además películas de las compañías Kinemacolor Comerio, Chronochrome Gaumont y Pathécolor. La iniciativa de la Cineteca de Bolonia sin duda puso en valor de nuevo el extraordinario impacto que causaron las películas Kinemacolor en su época y el legado de enorme importancia que tienen estas películas para la historia del cine. Aunque nuestra mirada sobre el mundo y nuestra apreciación acerca de las imágenes que vemos en la pantalla han variado en más de un siglo de manera indudable, el valor técnico de estas películas fue, y continúa siendo, equiparable a su calidad artística. Estas imágenes vistas hoy día parecen contemplarnos desde el otro lado de un cristal, tan lejanas y tan próximas a la vez en el tiempo y en el espacio, por momentos, evanescentes; imágenes que pretenden, y consiguen, aprehender el color. Películas como aquella Parrot on Perch and Goldfish in Bowl con la que Edmund Raymond Turner retrató a sus hijos sujetando girasoles entre sus pequeñas manos mientras observaban a un pez que nadaba en la translúcida pecera. Una ventana en el tiempo que abría un camino repleto de posibilidades.

Luke McKernan señala con gran acierto: «De la manera en que el Kinemacolor se veía realmente se ha perdido en el tiempo. Lo que veían los espectadores de entonces no es lo que vemos nosotros ahora. Delante de sus ojos se abría un mundo nuevo; nosotros vemos un mundo perdido para siempre» (McKernan, 2017: 36).

Actualmente se conservan películas Kinemacolor, además de en la citada Cineteca de Bolonia, donde se atesora la colección mas importante de nitratos del periodo comprendido entre 1908 y 1912, en archivos de Francia, Inglaterra, Holanda,

${ }^{41}$ McKernan, Luke, Discovering Kinemacolor, <https://lukemckernan.com/> (2/7/2020).

${ }^{42}$ Se conservan 23 títulos que corresponden a 6000 metros de película en 45 rollos. Dato extraído de I Colori Ritrovati. Kinemacolor e altre magie, p. 40. 
Rusia y Estados Unidos ${ }^{43}$. De los aproximadamente mil títulos que rodó la compañía Kinemacolor entre 1908 y 1917 apenas se conservan cincuenta ${ }^{44}$. Tanto la Cineteca de Bolonia a través del responsable de su archivo, Andrea Meneghelli, como el historiador Luke McKernan no han podido confirmar la existencia en sus fondos, ni en los de ningún otro archivo internacional, de alguna copia de las películas Kinemacolor rodadas en Canarias (A ambos me permito expresarles desde aquí mi agradecimiento por su ayuda).

Quizás esa violenta y asombrosa tormenta capturada cerca del litoral de Tenerife, las escenas callejeras de los pequeños pueblos y las panorámicas de los valles, el trabajo de los habitantes de las islas en las plantaciones de plátanos y en los muelles, las vistas de la cumbre del Teide cubierta de nieve, que se ofrecían en este primer catálogo de la compañía Kinemacolor, se encuentren atesoradas en algún lugar aguardando a que alguien las descubra y conserve para futuras generaciones. Podríamos entonces asistir como espectadores a las primeras películas rodadas en color en las Islas Canarias.

RECIBIDO: 28-10-2020; ACEPTADO: 5-2-2021

43 Relación de películas conservadas en archivos fílmicos. Consultar $<$ https://www.charlesurban.com/films_kinemacolor.html> (9/8/2020).

${ }^{44}$ Dato extraído de Kinemacolor e altre magie, p. 34. 


\section{BIBLIOGRAFÍA}

A Companion to Early Cinema (2012). Gaudreault, André; Dulac, Nicolas; Hidalgo, Santiago (eds.), UK: John Wiley \& Sons, Ltd.

Bazin, André (2004). ¿Qué es el cine? Madrid: Ediciones Rialp, S.A.

Braun, Marta. (2016). Early Film Colour, Today and yesterday, en Braun, Marta; O’Brien, Charles; Keil, Charlie; King, Rob; Moore, Paul \& Pelletier Louis (eds), Beyond the Screen: Institutions, Networks and Publics of Early Cinema. UK: John Libbey Publishing, Ltd.

Catalogue of Kinemacolor Film Subjects. Animated Scenes in Their Actual Colors (1913). London: Natural Color Kinematograph Co, Ltd.

Cherchi Usai, Paolo (2019). Silent Cinema; A Guide to Study, Research and Curatorship. London: The British Film Institute.

Encyclopedia of Early Cinema, (2005). Aвel, Richard (ed.), London and New York: Routledge.

I Colori Ritrovati, Kinemacolor e altre magie, (2017). Lewinsky, Mariann e McKernan, Luke (eds.), Bologna: Cineteca Bologna.

McKernan, Luke. (2017). Kinemacolor. A Short Story, Lewinsky, Mariann e McKernan, Luke (eds.), I Colori Ritrovati, Kinemacolor e altre magie (pp. 32 -36). Bologna: Cineteca Bologna.

Rodajes en Canarias (1896-1950) (2004). Gorostiza López, Jorge (coord.), Islas Canarias: Filmoteca Canaria, Viceconsejería de Cultura y Deportes, Gobierno de Canarias.

SADoul, Georges (1993). Las maravillas del cine. México: Fondo de cultura económica. 



\title{
LA CRISIS DEL COMANDO EN EL CINE NORTEAMERICANO DE GUERRA SUBMARINA EN LOS PERÍODOS DE POSGUERRA: LOS CASOS DE RUN SILENT RUN DEEP (ROBERT WISE, 1958) Y CRIMSON TIDE (TONY SCOTT, 1995)
}

\author{
Francisco Trujillo García-Ramos \\ Universidad de La Laguna
}

\section{RESUMEN}

La crisis del comando como argumento ha sido empleada en muchas referencias del cine de género bélico a lo largo de los años, pero es en las historias enmarcadas bajo la superficie del mar donde puede alcanzar mayor capacidad de desestabilización. Las películas del subgénero propuestas para ejemplificar este estudio son las norteamericanas Run Silent Run Deep (Robert Wise, 1958) y Crimson Tide (Tony Scott, 1995). Ambos filmes fueron producidos durante períodos de posguerra y narran la rivalidad de un comandante y su primer oficial en submarinos de la Marina de Guerra de los Estados Unidos en tiempo de guerra. Estos problemas de gobierno repercuten gravemente en el ecosistema de los navíos, generando una lucha por el control durante las patrullas. Mediante la observación de la muestra se examinará la relación de estas películas con la historia, así como las estrategias y procesos narrativos con el objetivo de verificar claves en el uso del relato.

Palabras clave: cine, Estados Unidos, Marina, guerra, submarino, comando, crisis.

THE COMMAND CRISIS IN NORTH AMERICAN SUBMARINE WAR CINEMA

IN THE POST-WAR PERIODS: RUN SILENT RUN DEEP (ROBERT WISE, 1958)

AND CRIMSON TIDE (TONY SCOTT, 1995) PROPOSALS

\section{Abstract}

The command crisis as a story line has been used in many references of the cinema war genre throughout years, but it is in the stories framed under the surface of the sea where it can reach its greatest destabilization capacity. The films of the subgenre suggested to exemplify this study are the North American Run Silent Run Deep (Robert Wise, 1958) and Crimson Tide (Tony Scott, 1995). Both films were produced during a post-war era and narrate the rivalry of a commander and his executive officer in wartime submarines of the United States Navy. Commanding problems severely affect the ecosystem of the ships, creating a struggle for control during patrol. By means of observation, the relationship between History and these films will be analysed, as much as the strategy and narrative process with the objective of verifying keys in the use of the plot.

KeYwords: cinema, United States, Navy, war, submarine, command, crisis.

DOI: https://doi.org/10.25145/j.latente.2021.19.03

Revista Latente, 19; noviembre 2021, pp. 45-72; ISSN: e-2386-8503 


\section{INTRODUCCIÓN}

El cine de guerra submarina es una subdivisión dentro del género bélico y se caracteriza por situar el escenario del drama en un entorno hostil, donde la tripulación de uno o más submarinos militares entra en combate con el enemigo bajo la superficie del mar o sobre ella. El subgénero comparte ciertas líneas temáticas con el correspondiente al de combate de naval, pero presenta una serie de singularidades que lo caracterizan de forma diferenciada. Algunos de los modelos semánticos y estructurales que las películas de guerra submarina tratan regularmente son, entre otros, la figura emblemática del padre-capitán, el confinamiento de una tripulación homosocial, la atmósfera de domesticidad, el particular uso del sonido, la ausencia de violencia gráfica en combate o el suspense en la puesta en escena (Koldau 2012: 104-109). Otras consideraciones también señalan el marcado carácter hermenéutico de las películas submarinas, que manifiesta "signos y significados constantemente» ${ }^{1}$ y un «profundo interés por la cuestión de la muerte, mucho más acentuado que en el western o la película bélica» ${ }^{2}$ (Nichols 2009: 102).

Como el resto de películas bélicas, el cine de guerra submarina se caracteriza por construirse generalmente sobre bases históricas. Ello implica la problemática de la interpretación del hecho real y la parcialidad en el punto de vista, ya que tanto sus protagonistas como los antagonistas normalmente representan a determinadas fuerzas armadas reales. Por lo tanto, se debe tener en cuenta que el modelo cultural de cada nación tiene su propia visión de la guerra (Rodríguez 2006: 164). De hecho, en un orden más amplio de la cuestión, el cine entendido como fuente para la historia ha necesitado mucho tiempo para ser considerado un documento válido en la investigación académica (Ferro 1995: 15). Esto contrasta con su enorme popularidad, que lo ha establecido como la principal fuente de consumo del hecho histórico (Rosentone 1988: 1174).

Para este estudio se han seleccionado dos películas norteamericanas realizadas durante períodos de posguerra como muestra de referencia y, a continuación, se han observado las particularidades en la representación de los escenarios de crisis del comando.

Run Silent Run Deep (Robert Wise, 1958) y Crimson Tide (Tony Scott, 1995) son dos dramas bélicos que tratan sobre la ruptura entre el comandante y el primer oficial de una misma nave en un contexto de guerra. Ambas películas son historias de ficción. En el caso de Run Silent Run Deep, se trata de cine de época, es decir, representa hechos ficticios basados en un contexto real: el desempeño del servicio de submarinistas de la Marina de los Estados Unidos durante la Guerra del Pacífico. La película está basada en la novela homónima de Edward L. Beach Jr. (1918-2002),

${ }^{1}$ Por ejemplo, la instrumentación de la sala de control del submarino, el procedimiento técnico del disparo de torpedos o el uso del sónar.

2 El entorno submarino es siempre indiferente e «inalterable»; la supervivencia o la muerte no cambiará ni conquistará el océano. Este asunto también se aborda en el filme bélico naval Cruel Sea (Charles Frend, 1953). 
un condecorado oficial de la flota de submarinos de la Segunda Guerra Mundial y posterior autor de best sellers de combate naval. Esta fue la primera novela de su autor y también la más exitosa desde su publicación en 1955. Poco después, John Gay realizaría una adaptación libre del argumento para la productora cinematográfica Hecht-Hill-Lancaster. L. Beach, decepcionado con el resultado, dejó testimonio en una entrevista posterior al estreno de la película, de que la adaptación «no era fiel a su experiencia en la Marina» (Rayner 2007: 110). El reparto, encabezado por el dúo de estrellas de Hollywood Clark Gable y Burt Lancaster, se puso al servicio del realizador Robert Wise.

Wise inició su carrera como técnico de sonido y montador $^{3}$ durante la década de 1930 para la RKO Pictures. Posteriormente, y ya como director, filmaría algunas de las películas más exitosas de Hollywood en la década de los 60, como las oscarizadas West Side Story (1961) o The Sound of Music (1965). La filmografía de Wise llama especialmente la atención por su eclecticismo. El cineasta trabajó desde el cine de guerra submarina de Run Silent Run Deep (1958), alternando a un relato ubicado en un buque de guerra de superficie en The Sand Pebbles (1966), al cine de terror, la ciencia ficción o el género musical. Wise conseguiría incidir en la cultura popular notablemente con sus éxitos, algunos de ellos considerados hoy «clásicos del cine». El propio cineasta recapituló sobre la notable diversidad de su trabajo durante una entrevista en 1998:

I've been accused by some of the more esoteric critics of not having a style, and my answer to that always is this: I've done every genre there is, and I approach each genre in the cinematic style that I think is appropriate and right for that genre. I would no more have done The Sound of Music in the thinking and approach that I did in I Want to Live! for anything. So that's why I don't have a singular mark but I justify that by saying that it's just because of the number of genres I've done and the cinematic style that's proper for each one (Institute of International Studies, UC Berkeley 1998).

Run Silent Run Deep contó con el asesoramiento técnico del contralmirante Rob Roy McGregor ${ }^{4}$, un hombre con experiencia de gobierno en dos submarinos de Clase Gato de la flota norteamericana (USS Grouper y USS Sea Cat) en la Segunda Guerra Mundial. La producción se realizó en una de las décadas de mayor popularidad para este subgénero en Estados Unidos. Del mismo período también son Submarine Command (John Farrow, 1951), Operation Pacific (George Waggner, 1951), Torpedo Alley (Lew Landers, 1952) o The Enemy Below (Dick Powell, 1957), entre otras referencias. Estas películas homenajean en formato retrospectivo el esfuerzo

${ }^{3}$ Diez años después sería nominado al premio Óscar de la Academia (AMPAS) por su trabajo en el innovador montaje de Citizen Kane (Orson Welles, 1941).

${ }^{4}$ El cierre de la película muestra el siguiente epígrafe en pantalla: «Our appreciation to the Department of Defense, The United States Navy, and the officers and men of Submarine Flotilla 1 for the cooperation extended». 
de la Marina para lograr el éxito en el Pacífico, que, muy consciente de la estrategia para consolidar su buen servicio mediante el poder comunicador del cine, accedió a prestar sus submarinos a los estudios de Hollywood ${ }^{5}$. La temática de la crisis del comando en algunos de estos filmes no evitó la condescendiente colaboración de las fuerzas armadas con los estudios durante este período de posguerra. En cualquier caso, tal y como se aborda en un apartado posterior de este artículo, estos relatos de crisis normalmente concluyen con una restauración de la buena imagen de la Marina (Rayner 2007: 114).

Run Silent Run Deep tuvo éxito en la taquilla ingresando un total de 3 millones de dólares de la época durante sus primeros 7 meses de exhibición en Estados Unidos (Lantern 2021).

Crimson Tide, realizada casi cuarenta años después del filme de Wise, es una historia original escrita por Michael Schiffer y el novelista de thrillers navales Richard P. Henrick. También es conocida la participación no oficial del cineasta Quentin Tarantino en el proceso de reescritura de la película (Internet Movie Database 2021). El contexto del relato es de ficción en la era post Guerra Fría y trata sobre la batalla que los Estados Unidos libran contra hipotéticos adversarios radicales de la República Rusa. La cinta fue producida por Don Simpson y Jerry Bluckheimer, exitoso dúo de Hollywood en las décadas de 1980 y 1990. Algunas de sus películas fueron grandes éxitos en la taquilla mundial, como Flashdance (Adrian Lyne, 1983) o Beverly Hills Cop (Martin Brest, 1984). Para Crimson Tide, Simpson y Bluckheimer contrataron a Tony Scott como realizador. Scott ya era muy reconocido por sus éxitos en publicidad y en el género del cine de acción. El estilo vibrante, moderno e hiperbólico en la puesta en escena del director había revolucionado pocos años antes el imaginario visual de la Fuerza Aérea de los Estados Unidos en otra película bélica del dúo Simpson-Bluckheimer: Top Gun (Tony Scott, 1986).

Crimson Tide inició su producción en 1993, pocos años después del éxito de otro filme de guerra submarina en el contexto de la Guerra Fría: The Hunt for Red October (John McTiernan, 1990), que obtuvo una recaudación de más de 200 millones de dólares en la taquilla internacional (Box Office Mojo 2020), y supuso para una audiencia moderna un revival del subgénero, ahora localizado en los avanzados submarinos nucleares estratégicos. No obstante, Crimson Tide no contó con el asesoramiento y participación de la Marina de los Estados Unidos durante su producción, al contrario que la película de McTiernan. La Armada rechazó el argumento del motín en un submarino norteamericano contemporáneo y decidió no colaborar con la producción (Suid 2002: 748). Crimson Tide no parecía que estuviese destinada a ser el eficaz instrumento de propaganda que sí resultó ser Top Gun. Tras el

5 En beneficio de ello, muchas películas de guerra submarina de la época tienen excelentes tomas exteriores de los auténticos navíos. Hoy en día se recurre habitualmente a las imágenes generadas por ordenador (CGI) para recrear estos submarinos en la pantalla con resultados de un realismo discutible. 
éxito de esta película, el aumento de cifras en los alistamientos para la Fuerza Aérea de los Estados Unidos se estimó en un 500 por ciento (Robb 2004: 182).

Una vez comenzado el rodaje, el equipo de fotografía realizó tomas aéreas exteriores del auténtico USS Alabama abandonando el puerto en Pearl Harbor sin prevenir al buque ni contar con permiso expreso. No obstante, la filmación pudo llevarse a cabo, ya que es acorde a la ley norteamericana grabar y difundir imágenes de una nave militar en espacio público (Ryan 1995). El material de ese día puede verse durante la escena en la que el Alabama zarpa y poco después se sumerge al comienzo de la película. Por el contrario, la Marina Nacional francesa sí colaboró con la producción, y se rodaron varias tomas en el portaaviones Foch (R-99) empleadas en la escena del noticiario de los primeros minutos de la película.

Crimson Tide se rodó pocos años después del fin de la Guerra Fría. Las relaciones entre los Estados Unidos y la nueva Federación Rusa se habían encauzado, aunque en Moscú se vivían tiempos muy inestables de crisis institucional, agravada por los extraordinarios sucesos del Octubre Negro en 1993. La película de Tony Scott interpretó esta realidad virándola hacia un relato de guerra con una hipotética oposición radical de la nueva república.

Crimson Tide fue un éxito en la taquilla internacional el verano de su estreno en 1995, con una recaudación que alcanzó la cifra de 157 millones de dólares (Box Office Mojo 2020). La película ha sido editada en múltiples formatos domésticos desde su estreno en las salas, y tampoco ha dejado emitirse por canales de televisión desde entonces. Actualmente, es considerada uno de los 5 filmes más populares de todos los tiempos dentro del subgénero de guerra submarina en el portal web IMDB (Internet Movie Database 2021).

Durante una entrevista concedida pocos ańos antes de su muerte en 2012, Tony Scott dejó testimonio de la relación de su filmografía con la consolidación popular de los denominados «clásicos del cine»:

I always get criticized for style over content, unlike Ridley's [Scott] films like Alien, Blade Runner or Gladiator that go right into the classic box right away. Mine sort of hover. Maybe with time people will start saying they should be classics, but I think I'm always perceived as reaching too hard for difference, and difference doesn't categorize you as the «classic» category (Cinema Blend 2009).

Al contrario que Wise, Scott recapitula sobre la crítica recibida por su énfasis en la estética en detrimento del contenido. Cabe destacar que ambas películas de la muestra coexisten en una escena durante el primer acto de Crimson Tide: el momento está protagonizado por dos oficiales que charlan animadamente sobre cine de guerra submarina y se cita, entre otras, a Run Silent Run Deep. De esta manera, la película de Scott cataloga al filme de Wise como un clásico dentro del subgénero. 


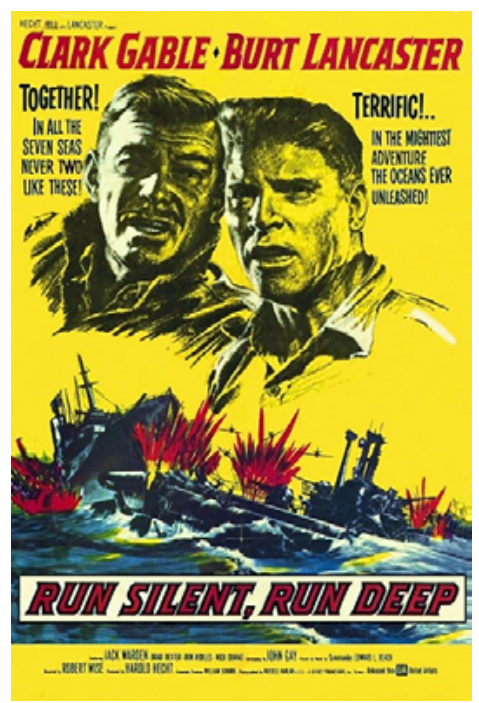

Fig. 1. Cartel promocional de Run Silent, Run Deep (Robert Wise, 1958).

Hecht-Hill-Lancaster Productions.

\section{SINOPSIS ARGUMENTAL}

\subsection{RUN SILENT RUN DEEP}

Run Silent Run Deep sitúa su historia en 1942 durante la Guerra del Pacífico y comienza con el hundimiento de un submarino de la Marina de los Estados Unidos perpetrado por un destructor japonés Akikaze en el canal de Bungo, cerca de la costa de Japón ${ }^{6}$. Su comandante, J.P. Richardson (Clark Gable), sobrevive al ataque y quedará marcado por la sed de venganza. Poco después, hastiado y reubicado en una oficina de la base norteamericana en Pearl Harbor, no dudará en solicitar el comando del USS $\mathrm{Nerka}^{7}$ al recibir noticias de su próxima patrulla cerca del canal. La denominada «zona 7» se ha cobrado nuevos hundimientos de la flota norteamericana y es temida entre la marinería. Secretamente, Richardson proyecta utilizar el submarino y su tripulación para introducirse unilateralmente en la zona y culminar su vendetta con el destructor de la Armada Imperial. Como consecuencia,

${ }^{6}$ La flota submarina norteamericana puso en servicio 288 submarinos durante la Segunda Guerra Mundial perdiendo 52, de los cuales 48 fueron hundidos en el Pacífico (Mata, cap. 1).

7 Se trata de una nave ficticia ya descrita en la novela. Para la filmación de sus tomas exteriores, la Marina cooperó prestando a la producción el USS Redfish, un submarino oceánico de Clase Balao (Rowan 2012: 136). 
el teniente Jim Bledsoe (Burt Lancaster), un joven primer oficial muy apreciado por la tripulación del Nerka, perderá su oportunidad de ascender en favor del desconocido Richardson, conservando el puesto de segundo a su pesar.

Tras un tenso encuentro en tierra y una vez asignado el mando, ambos deberán patrullar en un ambiente de incertidumbre: ni Bledsoe ni la tripulación confían en su nuevo comandante. Durante el trayecto, Richardson ordena duros ejercicios de entrenamiento y el submarino entra en combate exitosamente. No obstante, las incipientes sospechas sobre el destino secreto del Nerka darán pie a un conato de motín y graves problemas de convivencia.

Finalmente, el Nerka consigue llegar hasta los límites del canal de Bungo y se encuentra con un convoy japonés. Richardson decide atacar y consigue enviar a pique un barco de carga. El contraataque japonés por aire no tarda en llegar y es muy severo: el comandante resulta gravemente herido al golpearse, quedando incapacitado. Bledsoe asume el gobierno del Nerka y ambos se identifican en su determinación para regresar a la "zona 7», aliándose por primera vez desde el comienzo de la película.

La batalla final revela que el verdadero enemigo era un submarino japonés. El Nerka logra abatir al navío y al Akikaze enemigos en un ejercicio de total cooperación en el comando y alcanza la victoria. Richardson colapsa poco después de ver su objetivo consumado y muere. Bledsoe, ya como comandante, pondrá rumbo a la base en Pearl Harbor luego de oficiar un funeral militar en la mar, en el que declara: «que nadie aquí, nadie a bordo de esta embarcación pueda decir que no tuvimos un capitán».

\subsection{CRIMSON TIDE}

Crimson Tide es contemporánea de un hipotético año 1995, y da comienzo con un prefacio en pantalla: «Los tres hombres más poderosos del mundo: el presidente de los Estados Unidos, el presidente de la República Rusa... y el comandante de un submarino de misiles nucleares de los Estados Unidos»" ${ }^{9}$. A continuación, un noticiario informa sobre una grave crisis en la república: los rusos han bombardeado

${ }^{8}$ Existe un corte extendido de la película con 7 minutos extra que fueron eliminados en el montaje para las salas de cine. Este corte inédito se comercializó en formato DVD en 2006, pero la posterior reedición en disco Blu-ray de 2008 los volvería a eliminar. La mayor parte del nuevo metraje no contiene cambios sustanciales en la trama, ya que se trata de secuencias extendidas de camaradería entre la tripulación. Sin embargo, hay una escena que describe la buena relación personal entre Hunter y el contramaestre "COB" antes de la quiebra en el gobierno del Alabama. Estos minutos de metraje adicional aportan complejidad a la relación de «COB» con el comando y añade carga emotiva a su dilema.

9 Se perpetúa así el mito del submarino propuesto por Koldau bajo la definición de Howells: «un sofisticado concepto social de representación». En este caso en su versión excelsa: el temible submarino de misiles balísticos nucleares, un arma estratégica capaz de desatar el holocausto nuclear (Koldau 2011: 66). 


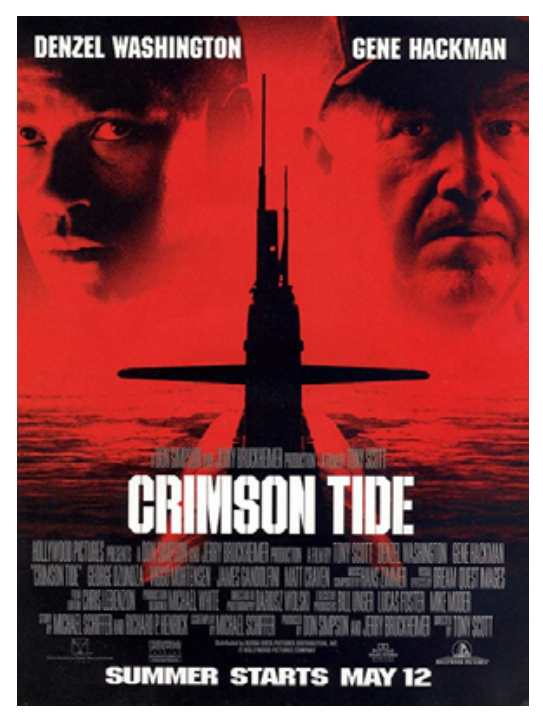

Fig. 2. Cartel promocional de Crimson Tide (Tony Scott, 1995). Hollywood Pictures y Don Simpson / Jerry Bruckheimer Films.

grupos rebeldes chechenos, lo que promueve sanciones internacionales como la suspensión de toda ayuda externa por parte de Estados Unidos. En consecuencia, el líder opositor ultranacionalista Vladimir Radchenko ${ }^{10}$ (Daniel von Bargen) provoca un enfrentamiento al borde de la guerra civil en el país y toma el control de una base nuclear de misiles intercontinentales bajo la amenaza de ataque a los Estados Unidos en caso de intromisión.

La crisis internacional moviliza a la Armada para poner en servicio al USS Alabama (SSBN-731), un submarino nuclear de Clase Ohio que existe como tal en la realidad y que forma parte de la flota de la Marina de los Estados Unidos desde su botadura en 1984 (Submarine Force Pacific 2020). El veterano capitán Frank Ramsey (Gene Hackman) comanda una misión hacia latitudes de ataque, para la que alista al joven teniente Ron Hunter (Denzel Washington) como primer oficial. Desde el comienzo de su cogobierno quedará patente que se trata de dos hombres de diferente filosofía: mientras Ramsey es un marino de la vieja escuela y cree en el cumplimiento de la orden y el buen oficio Hunter tiene una educación moderna de corte intelectual, con una visión y valores complejos.

El cisma en el comando surgirá con la orden de atacar con armamento nuclear en suelo ruso, para lo que comandante y primer oficial acuerdan comenzar el proce-

${ }_{10}$ El personaje puede haber sido concebido como una exageración del efímero presidente interino Aleksandr Rutskói. 
dimiento de disparo. Poco después, durante un enfrentamiento submarino, la nave recibe otro mensaje referente al uso de los misiles, pero llega incompleto debido a la profundidad. Ramsey entonces decide proceder unilateralmente con el lanzamiento sin el consentimiento de Hunter. El primer oficial tiene serias dudas sobre el contenido del segundo mensaje: podría tratarse de una contraorden para cancelar el disparo $^{11}$. Sin conseguir llegar a un consenso, Hunter ordena reemplazar a Ramsey y toma el gobierno. El nuevo líder del Alabama deberá mediar con la tripulación, muy dividida, y solventar el problema de recepción del segundo mensaje. Poco después, el bando afín a Ramsey retoma el control del submarino por la fuerza en el mismo momento en el que, finalmente, el Alabama recibe el segundo mensaje íntegro. La orden es abortar todo ataque. Ramsey, derrotado, cede el comando a Hunter.

De regreso a la base en Pearl Harbor, ambos serán requeridos por una junta de investigación en el Cuartel General de la Flota del Pacífico, donde el contraalmirante Anderson (Jason Robards) resuelve lo siguiente: «pudo tener la razón Hunter, pero en lo tocante a la ley ambos la tenían y ambos estaban equivocados». Al disolverse la junta, los dos comandantes tendrán un breve encuentro de reconciliación. El epílogo de la película anuncia una actualización del decreto por el cual la decisión de lanzar misiles nucleares es autorizada únicamente por presidente de Estados Unidos como comandante en jefe.

\section{CRISIS DEL COMANDO EN EL CINE DE GUERRA SUBMARINA NORTEAMERICANO}

La película bélica naval Caine Mutiny (Edward Dmytryk, 1954) comienza con la siguiente leyenda en pantalla: «Nunca ha habido un motín en un barco de la Marina de los Estados Unidos». No obstante, en el historial del servicio de Marina de superficie norteamericana se pueden hallar referencias documentales de amotinamientos o sucesos de reemplazo del comando en tiempos de guerra ${ }^{12}$. En lo que concierne a las naves de oficio submarino, resulta muy complicado localizar un incidente de la misma naturaleza; hasta el recientemente difundido caso del USS Florida, que tuvo como conclusión el relevo de su comandante en el año 2018 ( $\mathrm{La}$ Razón 2019) $)^{13}$.

${ }^{11}$ Este episodio tiene su equivalencia histórica en el incidente ocurrido durante la crisis de los misiles de Cuba en 1962 a bordo del submarino soviético B-59. La nave fue sitiada por buques de superficie norteamericanos que soltaron cargas de profundidad inocuas a modo de señal para que el submarino emergiese. Creyéndose bajo ataque, el capitán del B-59 estuvo a punto de ordenar el disparo de armamento nuclear desde las profundidades, donde no hay contacto posible por radio. El voto en contra del comandante Vasily Arkhipov para autorizar el uso de la fuerza evitó el desastre (Ketov 2005: 217-231).

${ }^{12}$ Más de un siglo antes del estreno de la película de Dmytryk, sucedió el motín del USS Somers durante la intervención estadounidense en México en el año 1842.

${ }_{13}$ Un incidente de índole sexista se desencadenó por la redacción de unas «listas de violación» por parte de algunos marineros. Como resultado se tomó la decisión de destituir al coman- 
Durante la Segunda Guerra Mundial, eran habituales los filmes producidos en Hollywood con destacados elementos de propaganda, como Destination Tokyo (Delmer Daves, 1943), una heroica aventura de guerra submarina donde nunca se cuestiona al comando. De hecho, el capitán del USS Copperfin, encarnado por el carismático Cary Grant, es retratado en la película como la idealización de un padre bondadoso. No obstante, ya en la posguerra, el cine bélico norteamericano comienza a abandonar las historias de personajes unidimensionales para avanzar hacia relatos basados en los conflictos del gobierno y el cuestionamiento de la figura patriarcal. Los estudios de Hollywood proyectaban este escenario argumental como espacio de duelo interpretativo para sus estrellas, recurriendo a las historias de ficción, sumando la atractiva estética bélica y el suspense al servicio del drama (Koldau 2012: 114). Bajo esta temática y enmarcadas en el servicio de marina de superficie, debuta la ya mencionada Caine Mutiny y también Away All Boats! (Joseph Pevney, 1956). En lo que respecta a las películas en dotaciones submarinas, se estrena la aquí analizada Run Silent Run Deep, y también Torpedo Run (Joseph Pevney, 1958), Submarine Seahawk (Spencer Gordon Bennet, 1958) o Up Periscope (Gordon Douglas, 1959). Estos filmes sitúan en el centro del drama el conflicto personal y/o profesional en base a una contraposición de objetivos entre los personajes del hábitat submarino y están especialmente representados en la figura del comandante y el primer oficial. Las estrategias narrativas aplicadas al relato no están exentas de matices edípicos y siempre derivan en un grave perjuicio en las relaciones del comando con el resto de la marinería. Por lo tanto, la batalla contra el enemigo externo, determinante en los relatos bélicos rodados en tiempo de guerra, ocupa en estas películas una función contextual y asume el rol de generador de tensión para un argumento basado principalmente en la quiebra de la convivencia.

Rayner describe las singularidades que el cine de guerra submarina presenta respecto a la crisis del comando en relación con otros subgéneros bélicos. También resulta especialmente reveladora su observación sobre la habitual restauración y refuerzo de la imagen de la autoridad y, por lo tanto, de la Marina, en las conclusiones de estas películas junto con las enmarcadas en la guerra naval de superficie:

... The insubordination appears more serious, and comes closer to outright mutiny, in the submarine films may be related to their representational specificity. [...] The confinement of the submarine's internal spaces, allied to the boat's remoteness from the chain of command, may make the narrative and military authority of the commander appear more arbitrary, and as a result more likely to provoke confrontation. [...] As in the films which treat surface ships, the Oedipal threat is never fully realised, and the subordinate officers accept their institutional roles, or achieve command authority themselves, if only when the patriarch bequeaths

dante. La ausencia de mujeres en la tripulación de los submarinos militares norteamericanos fue una realidad hasta hace pocos años. Este hecho ha convertido al subgénero en "películas masculinas», hasta el punto que la intromisión de la mujer a bordo ha dado pie para la realización de comedias, como el caso de Operation Petticoat (Blake Edwards, 1959). 
it. [...] The implied rebellion is not only contained, but ultimately reversed, to produce a picture of appropriately distributed, exercised and inherited authority, which reinforces rather than challenges the patriarchal naval establishment (Rayner 2007: 109-114).

\section{RUN SILENT RUN DEEP Y CRIMSON TIDE: DOS VARIANTES DE LA CRISIS DEL COMANDO EN EL CINE DE GUERRA SUBMARINA}

\subsection{LA CARACTERIZACIÓN DE LOS PERSONAJES PROTAGONISTAS}

La lucha de perfiles opuestos es el eje central de las dos películas estudiadas. El comandante y el primer oficial ocupan puestos de poder, respeto y liderazgo en los submarinos. Sin embargo, estos personajes confrontan entre sí al mismo tiempo que trabajan en equipo, lo que amplifica enormemente las posibilidades dramáticas. Ambos se pueden definir fundamentalmente en un binomio estereotipo entre un hombre joven y capacitado en contraposición a la figura del hombre maduro y experimentado encarnado por el comandante. Pese a ello, la contradicción que expresan los retratos de Richardson y Ramsey, ambos obstinados y, en última instancia, aciagos, aporta dimensión a los caracteres; lo que los convierte en protagonistas vehiculares para el modelo de relato (McKee 2002: 446-460).

El comandante Richardson se presenta en Run Silent Run Deep como un hombre de familia de edad avanzada ${ }^{14}$, marino curtido, derrotado en el campo de batalla y con una gran determinación por materializar su deseo de venganza. La opinión que pueda tener la tripulación de su persona y su modo de gobernar le es indiferente ${ }^{15}$. De hecho, puede llegar a ser intransigente en los ejercicios de ataque y simulacros con la marinería, que es, a su modo de ver, una mera herramienta para alcanzar sus objetivos. De la misma manera, llegará a desacatar órdenes de la Marina para reubicar la posición del navío a riesgo de abandonar su guerra particular. En el desempeño del comando resulta brillante en las tácticas de ataque; pero tras diferentes encuentros enemigos, la tripulación del Nerka no advierte a identificarlo como cobarde o temerario. No obstante, Richardson no es retratado como el villano de Run Silent Run Deep. Se trata de un personaje definido por la obsesión y fracturado por la derrota. En aras de un patriótico sentido de la lucha contra el enemigo, el comandante conseguirá alinearse con su primer oficial en el tramo final de

${ }^{14}$ Clark Gable se encontraba en un delicado estado de salud durante el rodaje de la película. Puede observarse al actor sufriendo temblores en muchas de las escenas, un detalle que aporta un viso trágico al personaje. El actor murió el 16 de noviembre de 1960, dos años después del estreno de la película.

15 De la misma manera que en Crimson Tide, la dureza del comandante en el trato con la tripulación se contrapone a la empatía dispensada por parte del primer oficial. 


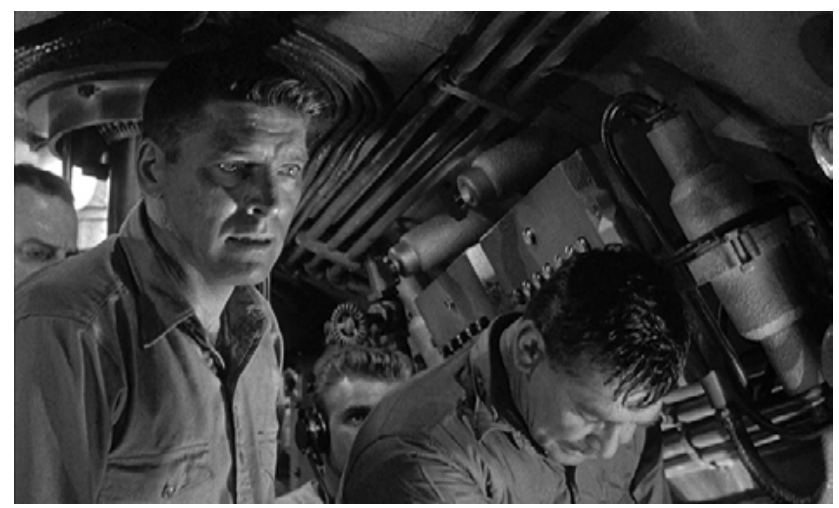

Fig. 3. Richardson cede el liderazgo a Bledsoe durante el último acto de Run Silent Run Deep (Robert Wise, 1958). Hecht-Hill-Lancaster Productions.

la película. Richardson llegará a consumar su objetivo y destruir al enemigo, pero también será víctima de sus acciones, lo que le convierte en un personaje trágico ${ }^{16}$.

Por el contrario, el teniente Jim Bledsoe es un hombre joven, íntegro y que cree en el cumplimiento de las normas de la Marina. Burt Lancaster aporta su carisma al personaje, pero el actor modera su reconocida sonrisa para ofrecer una composición más dramática de la habitual. Bledsoe tiene capacidad para imponer el liderazgo y también es de carácter empático: muestra un sincero respeto por la familia de tripulantes que habita el Nerka y estos, a su vez, le corresponden. No obstante, deberá lidiar con la contradicción de estar al servicio en patrulla para un comandante que ha interceptado su ascenso. Bledsoe tiene la difícil tarea de coordinar gobierno y una recelosa tripulación, al mismo tiempo que examina su audacia para dirigir maniobras de ataque con riesgo mortal; la lección definitiva para postularse como líder del submarino ${ }^{17}$.

Comandante y primer oficial alternan el punto de vista de la puesta en escena en la películas de Wise, lo que repercute en mejorar la calidad del retrato para ambos e intensifica la empatía con la audiencia. Es el caso contrario a lo observado en Crimson Tide, donde rara vez se adopta la perspectiva del comandante en contraposición al protagonismo de Hunter.

${ }^{16}$ La obsesión del personaje liga directamente al autodestructivo capitán Ahab y su empeño por dar caza a la «ballena blanca» en Moby Dick (Herman Melville, 1851).

17 Resulta característico en el arco evolutivo del primer oficial el relato de aprendizaje para postularse a comandante. Al igual que en el caso de Hunter en Crimson Tide, esta instrucción tiene como objetivo sobrevivir a una guerra dentro del "hogar submarino» y también a la que se libra en el mundo exterior. 


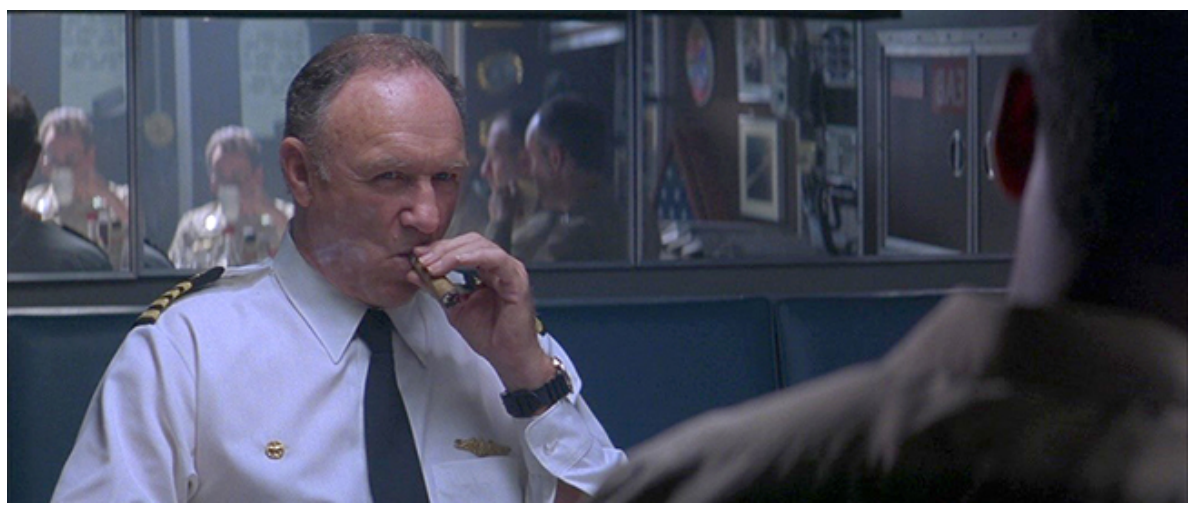

Fig. 4. El comandante Ramsey fuma un puro (símbolo del comando) en Crimson Tide (Tony Scott, 1995). Hollywood Pictures y Don Simpson / Jerry Bruckheimer Films.

El capitán Frank Ramsey es encarnado por Gene Hackman en Crimson Tide. $\mathrm{El}$ actor proporciona al personaje su estilo contundente y resulta de una personalidad implacable en pantalla. Ramsey es el retrato de un hombre experimentado en combate y con reputación de ser muy exigente en el servicio. Del ámbito privado se sabe que tiene familia, pero está divorciado (se pueden observar en varias escenas de la película abundantes fotos de familia en su camarote, momentos de una vida tal vez ya pasada). Su desestructurada historia personal se insinúa estar ligada al gran compromiso que siente por la Marina. La lealtad a su mascota Bear, un jack russel terrier, lo avala a su vez como un hombre sensible ${ }^{18}$. Todo su apego exclusivo por la vida profesional parece ser generador de intransigencia cuando se trata del compromiso de la seguridad nacional, llegando al extremo de ser brutal en el momento de ejercer su autoridad. Ideológicamente, se trata de un personaje caracterizado por su fe en las certezas y el acatamiento del orden militar. El comandante Ramsey nunca aceptará el hecho de haber errado en su empeño por disparar las armas nucleares en Crimson Tide. Sin embargo, su obstinación no se sitúa en el terreno de un belicismo exacerbado tanto como en la convicción del ataque preventivo como medida proteccionista y el acatamiento del deber sin ambigüedades.

El teniente Ron Hunter es un joven primer oficial que representa la nueva escuela militar, con un historial de educación superior, pero sin experiencia en combate real. Denzel Washington interpreta a Hunter con la energía y determinación que caracteriza al personaje. El teniente es un hombre de familia afroamericano ${ }^{19}$

18 Un matiz en la caracterización del personaje que aporta volumen al retrato y contrasta con su marcado autoritarismo.

19 La película fue concebida poco después de los graves disturbios raciales de Los Ángeles en 1992. En Crimson Tide, el teniente Hunter llegará a ser sometido a abuso físico en una situación 


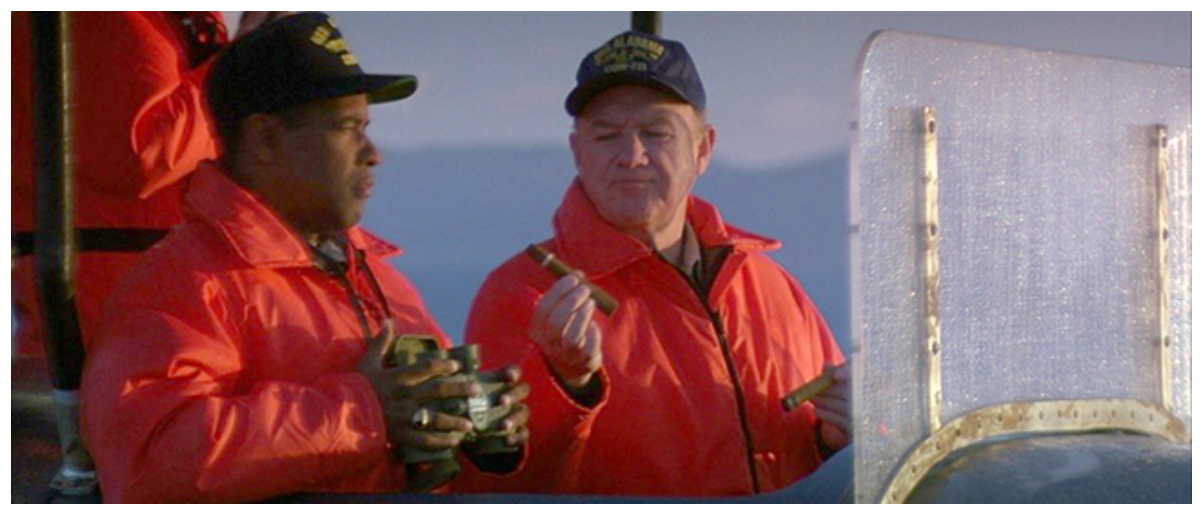

Fig. 5. Hunter es obsequiado con el "puro del comando" por parte de Ramsey. Crimson Tide (Tony Scott, 1995). Hollywood Pictures y Don Simpson / Jerry Bruckheimer Films.

felizmente casado: desde las primeras secuencias de la película, el espectador tiene acceso a la privacidad de su hogar, donde sigue con preocupación la última hora del conflicto internacional ${ }^{20}$. El riesgo real de guerra nuclear acentuado posteriormente por las unilaterales decisiones de Ramsey pondrá en peligro el contexto familiar que Crimson Tide describe en la residencia de los Hunter. Durante su patrulla en el Alabama, el primer oficial se caracteriza por la buena aplicación del reglamento, por sus ideas en clave positiva y por la conveniencia de la tripulación. Hunter encarna al héroe protagonista en el relato de Crimson Tide, y el espectador lo percibe así por empatía hacia la posible y devastadora pérdida personal a la que se enfrenta.

El origen de la relación entre comandante y primer oficial presenta de forma preliminar posicionamientos antagónicos de ambas partes, trazando el arco narrativo por el cual su relación se desarrollará. En algunos casos, estas escenas se extienden como instrumento de presentación de alguno de los dos caracteres ${ }^{21}$. Run Silent Run Deep propone un inesperado tono formal-informal, inclusive de farsa para la primera escena compartida por los personajes protagonistas. El momento comienza con la llegada de Bledsoe a la residencia de los Richardson vistiendo uniforme (símbolo

de vulnerabilidad. La escena en cuestión describe al primer oficial resignado a la brutalidad de un autoritario Ramsey en la sala de control, que lo golpea en varias ocasiones. La analogía entre este clímax de la crisis doméstica del Alabama y las revueltas en consecuencia del linchamiento a Rodney King por parte de un grupo de policías del LAPD señala a una posible investigación al respecto.

${ }_{20}$ Al contrario que el caso de Bledsoe en Run Silent Run Deep, sí podemos conocer la vida personal de Hunter. La ausencia de referencias sobre la vida privada de Bledsoe en tierra acentúa su papel como aspirante a "padre» del hogar alternativo, el Nerka, y la relación fraternal con la marinería.

${ }^{21}$ Ese es el caso de Crimson Tide, donde la escena de la entrevista también muestra al personaje del comandante Ramsey por primera vez en la pantalla. 


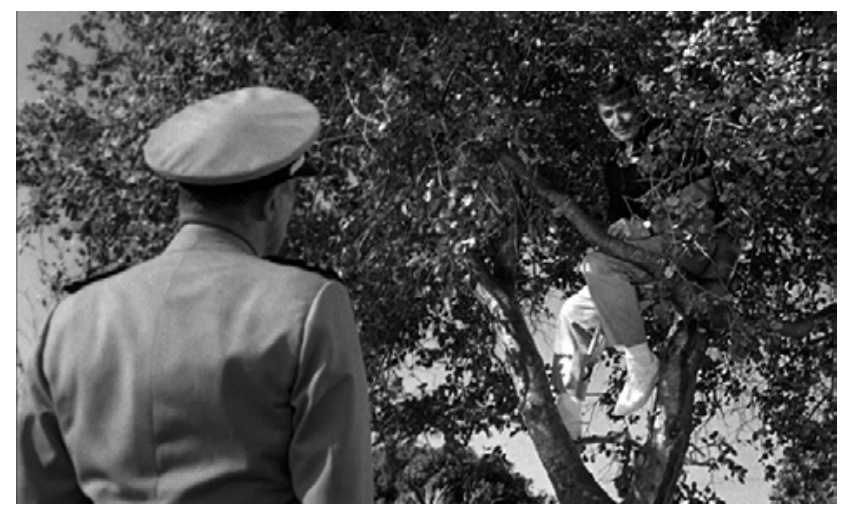

Fig. 6. Bledsoe se encuentra por primera vez con Richardson en su residencia. Run Silent Run Deep (Robert Wise, 1958). Hecht-Hill-Lancaster Productions.

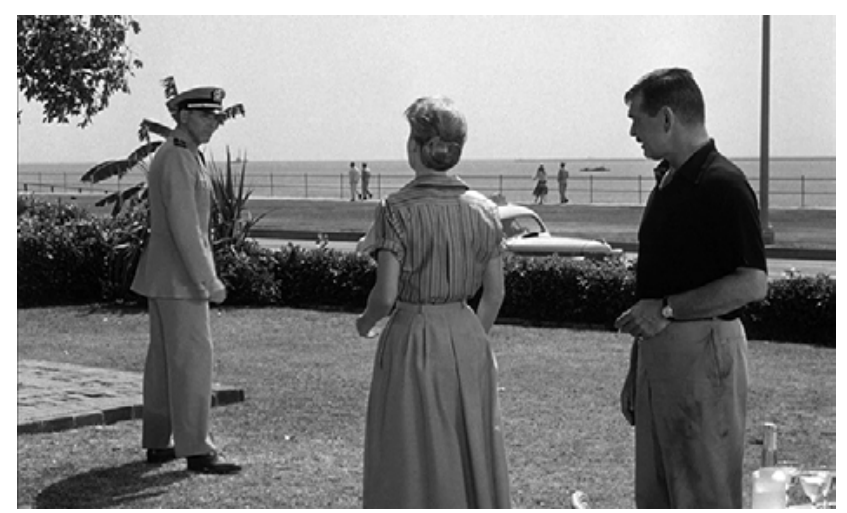

Fig. 7. Bledsoe y los Richardson durante la promesa. Tras ellos, el mar es testigo. Run Silent Run Deep (Robert Wise, 1958). Hecht-Hill-Lancaster Productions.

del oficio y la integridad). El primer oficial acude predispuesto al enfrentamiento y se encontrará con su comandante encaramado a un árbol del jardín con ropa de civil. Se inicia así, en un falso tono de comedia de equívocos, el duelo dentro del comando, proponiendo un equilibrio en la percepción por parte del espectador de ambos personajes protagonistas al situar al severo Richardson en el terreno de lo ordinario. En la escena también interviene Laura Richardson (Mary LaRoche), que fuerza las posiciones del uno y del otro en un triángulo hacia la buena colaboración. Laura comprometerá bajo una promesa a Bledsoe para velar por la vida de su marido, que viste durante la escena una premonitoria camisa negra.

Crimson Tide plantea la escena del primer contacto durante una noche de tormenta en el interior de las dependencias del comandante Ramsey. De nuevo se 

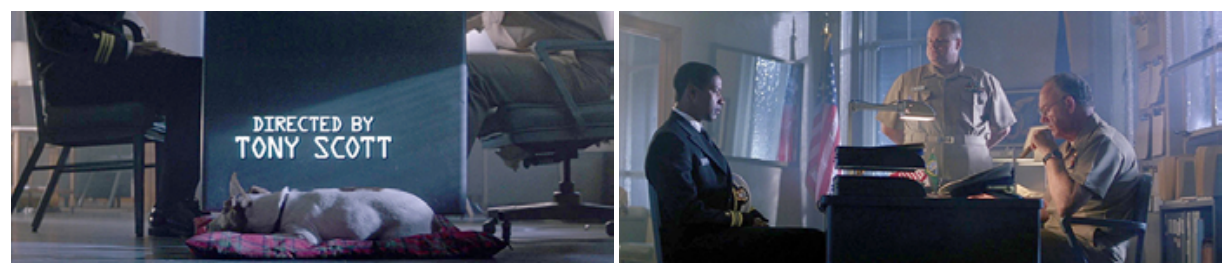

Fig. 8. El perro Bear avala a Hunter como primer oficial del Alabama en Crimson Tide (Tony Scott, 1995). Hollywood Pictures y Don Simpson / Jerry Bruckheimer Films.

establece una relación a tres partes, a la que se sumaría Bear, el terrier ${ }^{22}$. El contramaestre "COB»" ${ }^{23}$, ubicado simbólicamente entre Hunter y Ramsey, ejerce de testigo en una suerte de "entrevista-enlace»" ${ }^{24}$ Al contrario que el caso de Run Silent Run Deep, la escena se plantea manteniendo un formato militar y no implica una predisposición a la confrontación. Sin embargo, el comandante deja patente durante la conversación que debe sustituir a su estimado primer oficial por una baja, algo que visiblemente parece no resultarle cómodo a pesar de las buenas referencias del desconocido Hunter: «su nombre encabeza la lista. [...] era una lista muy corta». Durante la lectura del historial de Hunter, Ramsey muestra su sorpresa al leer el período de formación en la Universidad de Harvard. El comandante no parece que apruebe la educación superior como mérito en la Marina. Acto seguido, pregunta sobre intereses personales a Hunter, que responde sobre su afición por la equitación. Esta conversación será retomada en posteriores momentos clave de la película y representa en forma de diálogo una reconfiguración de la relación entre ambos hacia un trato entre dos partes iguales, entre "dos hombres».

El terrier del comandante tiene una inesperada importancia en el desarrollo de la escena, ya que dará la bendición final al mostrar su empatía con Hunter, cosa que Ramsey reconoce: "parece que usted le gusta». La importancia de Bear en la escena liga con el tono formal-informal visto en Run Silent Run Deep para su versión de la entrevista entre el comando. Tony Scott prolonga la farsa al situar su crédito como director en la escena de forma juguetona sobre la figura del terrier, ajustado en el espacio que distancia a los dos protagonistas.

${ }^{22}$ El comandante declara sobre su apreciada mascota: «no hay perro más inteligente que los jack russel, va a todos lados conmigo". Aquí la fidelidad de Bear con su amo parece servirse como ejemplo del comandante para con su primer oficial: la lealtad y el acatamiento como modelo de conveniencia para las buenas relaciones entre líder y subordinado.

${ }^{23}$ En Crimson Tide la marinería del Alabama es nombrada por las siglas de su cargo. Para el caso del contramaestre Walters resultaría "COB», de "Chief of the Boat» en inglés.

${ }^{24}$ Durante la escena puede escucharse la sonata n. ${ }^{\circ} 14$ para piano o "Claro de luna» de Beethoven. La pieza fue dedicada a la joven condesa Guicciardi, alumna del músico. Es conocido que el autor y la condesa vivieron una relación de amor utópica debido a la posición social incompatible entre ambos. La sonata expresa este sentimiento de melancolía y Crimson Tide se sirve de ella para transmitir el comienzo de un enlace sin futuro entre el comando. 
Otra escena de Crimson Tide localizada en el comedor de los oficiales durante el primer acto de la película expone claves ideológicas de los dos personajes. En ambiente de sobremesa, el comandante Ramsey charla coloquialmente sobre el manejo del armamento nuclear con su primero de a bordo: "[...] la Marina me quiere simple», «yo solo tengo que saber cómo apretar un botón y ellos [el comando en base] me dicen cuándo», y añade citando a Karl von Clausewitz: «la guerra es política continuada por otros medios $\aleph^{25}$. Hunter lo secunda, pero también aclara: «[...] la guerra tiende a servirse a sí misma» $\mathrm{y}$ «en el mundo nuclear el verdadero enemigo es la guerra». La opinión del primer oficial sobre el desempeño nuclear podría ser interpretada como pacifista, pero reside en el temor a la realidad que puede desencadenar el ataque y contraataque nuclear: un holocausto. Por parte de Ramsey, resulta inverosímil que el capitán de un submarino estratégico nuclear tenga una mentalidad propia de ataque convencional cuando se trata de desempeñar armas de esa naturaleza. Aun tratándose de un ataque preventivo a sabiendas de que el enemigo se está armando, es probable que la presencia de Hunter en la sala de control acentúe la terquedad de Ramsey y se justifique así por motivos de contraste ideológico, lo que coincide con la afirmación de Koldau sobre el incremento de la tensión psicológica en el cine de guerra submarina nuclear (Koldau 2012: 113).

\subsection{LA COMPLEJA RECIPROCIDAD DEL COMANDO CON LA TRIPULACIÓN: SUBLEVA- CIÓN Y DEFENSA}

El vínculo del comandante y del primer oficial con el equipo humano del navío es muy importante en la relación de fuerzas que se verán confrontadas. La tripulación tiene en última instancia el papel de reconocer o rechazar la autoridad de sus superiores. El cuadro de alianzas enfrentadas que se generan tras la quiebra del gobierno define de gran manera el devenir del conflicto. Si bien las competencias del segundo de a bordo están especialmente ligadas a un trato directo con la tripulación, el comandante también permanece en contacto con la marinería debido a las características espaciales y de proximidad propias de los navíos submarinos, y ambos se encuentran en la compleja posición de aunar gobierno, disciplina y moral.

En el primer acto de Run Silent Run Deep, el comandante Richardson, hastiado en la base en Pearl Harbor, mantiene estrecha complicidad con el subalterno Mueller, un hombre que conoce su secreta obsesión por cazar el destructor Akikaze, y que además le alienta a lograr su objetivo. Ambos compartirán destino en la patrulla del Nerka, lugar en el que Richardson cuenta únicamente con la amistad de su confidente. Mueller defenderá el honor del capitán durante toda la travesía, llegando a agredir al oficial Cartwright (Brad Dexter) tras una burla sobre su estado de salud. El comandante no tendrá más aliados durante la patrulla, y todos

25 Cita tomada del tratado De la Guerra (Karl von Clausewitz, 1832). Clausewitz fue un militar y teórico de la ciencia militar de gran influencia cuya obra es estudiada en las academias militares. 


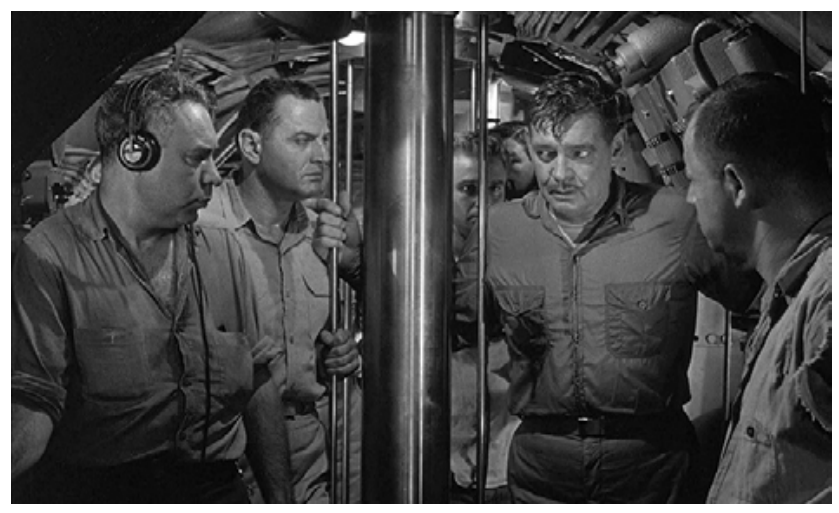

Fig. 9. Richardson es increpado en silencio por su tripulación en Run Silent Run Deep (Robert Wise, 1958). Hecht-Hill-Lancaster Productions.

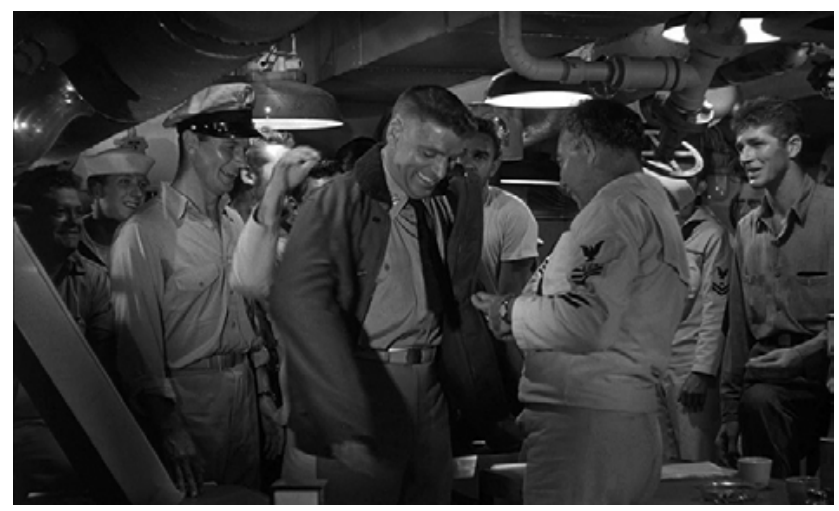

Fig. 10. Bledsoe recibe una chaqueta de capitán como obsequio de la tripulación del Nerka. Run Silent Run Deep (Robert Wise, 1958). Hecht-Hill-Lancaster Productions.

los oficiales manifiestan unánimemente el rechazo a Richardson cuando acuerdan planificar en secreto su reemplazo.

El primer oficial Bledsoe se presenta en pantalla durante una escena donde la tripulación del Nerka le hace entrega de una chaqueta ad hoc de comandante en un ambiente festivo. La cazadora actúa como un símbolo de la consolidación como miembro distinguido en el hogar submarino en el que conviven, así como el visto bueno para su ascenso. Poco después, la decepción del primer oficial al verse socavado del comando será igualmente compartida por sus compañeros.

Una vez desatada la crisis en el Nerka, la misma tripulación, representada en sus oficiales, apela al pacto de concordia con su primer oficial y lo convoca en secreto para proponer la destitución del comandante. Nada de ello bastará para evitar que Bledsoe disuelva la asamblea sin paliativos y elimine así toda opción de amotina- 


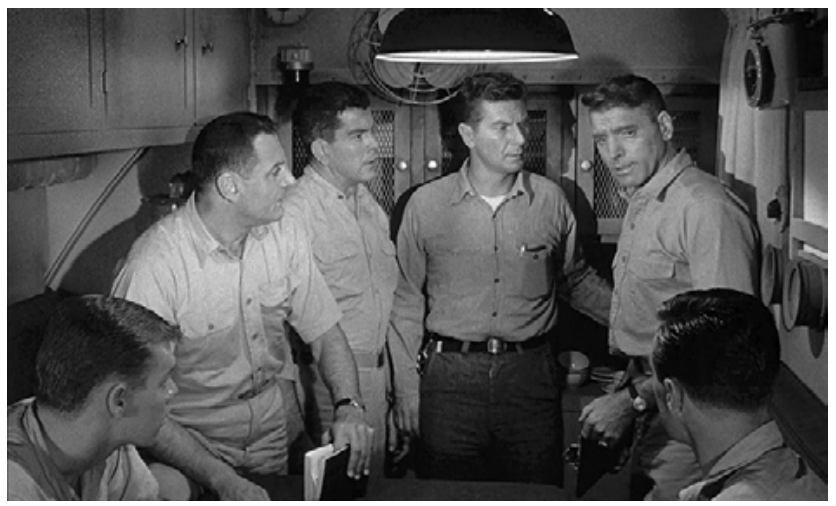

Fig. 11. Bledsoe es propuesto en secreto por la tripulación para sustituir al comandante. Run Silent Run Deep (Robert Wise, 1958). Hecht-Hill-Lancaster Productions.

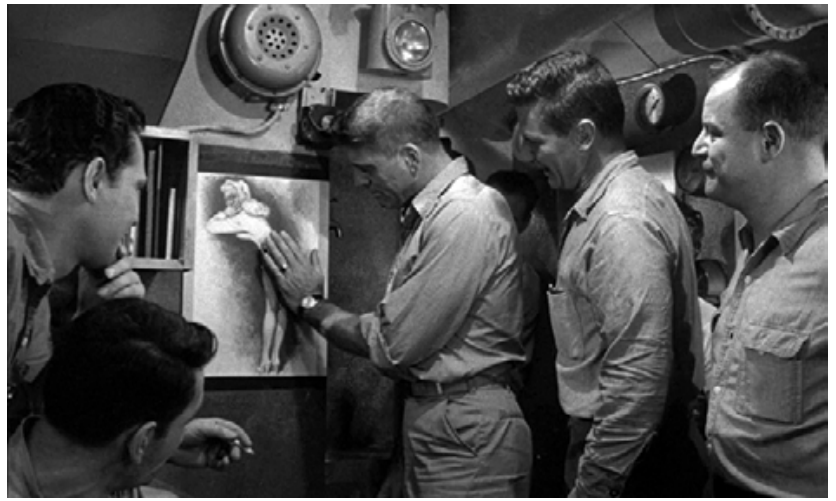

Fig. 12. El primer oficial es cordialmente invitado a participar en el ritual de la buena suerte. Run Silent Run Deep (Robert Wise, 1958). Hecht-Hill-Lancaster Productions.

miento, a pesar de la abrumadora unanimidad contra el gobierno de Richardson, inclusive la suya propia ${ }^{26}$. Todo ello pone en una situación delicada al primer oficial, ya que pierde temporalmente la confianza de sus oficiales.

Hacia el final de la película, la consolidación de Bledsoe como comandante de facto en el Nerka se sellará mediante otro acto simbólico instigado por el contramaestre Kohler (Joe Maross) y la tripulación: participar en una rutina entre los hombres de palmar el dibujo de la única tripulante femenina del submarino en forma de dibujo en la pared.

${ }^{26}$ Este hecho proclama la integridad de Bledsoe respecto al cumplimiento estricto de las normas, una característica habitual en el personaje del primer oficial. 


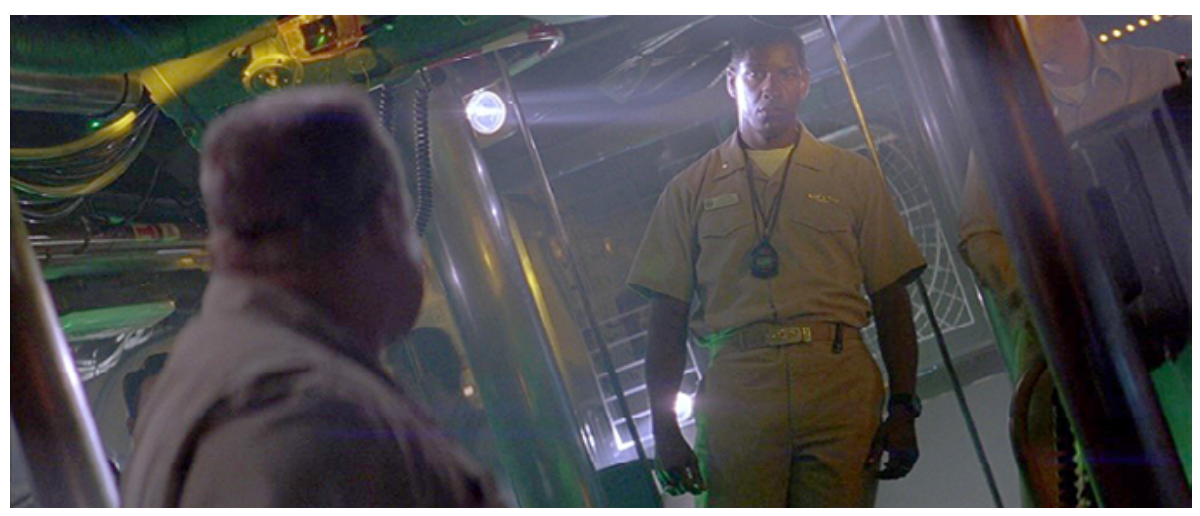

Fig. 13. «COB» apremia a Hunter para tomar una decisión de dramáticas consecuencias. Crimson Tide (Tony Scott, 1995). Hollywood Pictures y Don Simpson / Jerry Bruckheimer Films.

Por su parte, en Crimson Tide, el comandante Ramsey parece mantener una estrecha relación profesional con el contramaestre Walters «COB». Ambos se presentan en pantalla de forma simultánea y se da por supuesta una trayectoria conjunta en el Alabama ${ }^{27}$. No hay demostración de afinidad del comandante hacia el resto de su tripulación más allá del discurso que les dedica al comienzo de la patrulla. De hecho, este rechaza el trato empático propuesto por Hunter al avisar de la creciente tensión entre la tripulación de la nave una vez iniciada la misión.

Tras el incidente que provoca la revocación del comandante Ramsey, la tripulación del submarino queda en estado de shock al encontrarse sin un líder inequívoco. El primer oficial pasa a ser comandante accidental y no cuenta con la aprobación moral de la marinería. Hunter debe emplear el reglamento y la lógica para justificar su decisión de luchar por el control del $A_{l a b a m a^{28}}$, algo que le resulta complicado al no poder apelar a un vínculo personal más allá del oficial de armas Peter Ince «WEPS» (Viggo Mortensen). El nuevo e inexperimentado capitán conseguirá revertir la percepción de codicioso por una parte de la tripulación gracias a su buen oficio en el hundimiento del submarino Akula enemigo. Hunter también afrontará la difícil decisión de ordenar la muerte segura de tres hombres para salvar la nave durante unas maniobras de drenaje de emergencia; otra prueba extrema para alcanzar el estatus simbólico de comandante.

${ }^{27}$ No obstante, en la escena del corte extendido de la película mencionada anteriormente, Ramsey traslada a Hunter resolver con «COB» el «delicado tema de su sobrepeso». De este modo, Ramsey se exime de tener un encuentro incómodo con su contramaestre, lo que indica una relación tal vez no tan cercana. Por otro lado, debido a este asunto, Hunter estrechará lazos con el capataz.

${ }^{28}$ Inmediatamente después del relevo del capitán Ramsey, Hunter insta a que cualquier miembro de la sala de control abandone su puesto si está en desacuerdo con su decisión. De esta manera la actuación de Hunter se muestra como transparente a su tripulación. 


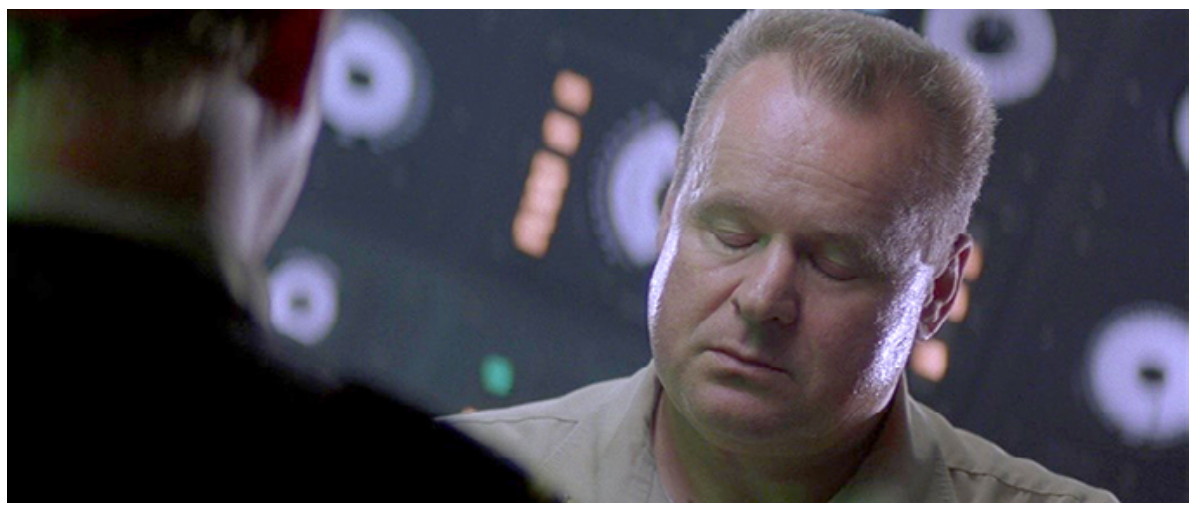

Fig. 14. El depuesto Ramsey reprende a "COB» tras retomar el gobierno del Alabama en Crimson Tide (Tony Scott, 1995). Hollywood Pictures y Don Simpson / Jerry Bruckheimer Films.

Varios de los oficiales en el Alabama lideran un motín para restituir al comandante en el último tercio de la película. La motivación de sus actos parece justificarse por el posicionamiento respecto al dilema del disparo del armamento nuclear, y no tanto por una vinculación personal con su comandante. Los oficiales Dougherty «SUPPO» (James Gandolfini), Zimmer «COMMO» (Matt Craven) y Westerguard "OPS-O» (Rocky Carroll) son los instigadores. Por su parte, el contramaestre "COB» cita el reglamento y no apoya Ramsey en su cruzada, dirigiendo el servicio de arresto al excomandante. Hunter agradece su apoyo en una conversación privada, pero solo encuentra la indiferencia del contramaestre: «entiéndalo bien, yo no estoy de su parte». Más tarde, Ramsey y «COB» tendrán un encaramiento tras su retorno al poder por asalto y, visiblemente defraudado, le recrimina su traición frente a la tripulación en la sala de control.

De entre el sector oponente a Hunter, se encuentra su amigo "WEPS». El teniente es uno de los invitados al cumpleaños en el hogar de los Hunter en el comienzo de la película y también el único miembro de la tripulación del Alabama que tiene acceso a su vida privada. También es quien presenta a Hunter a los nuevos oficiales del Alabama antes de comenzar la patrulla, puesto que el primer oficial desconoce prácticamente a toda la tripulación. No obstante, «WEPS», bajo presión, traicionará a su amigo para reponer el statu quo inicial, pero no quedará convencido de su propia actuación.

El abandono del círculo de confianza de Hunter por parte de «WEPS» arrincona al primer oficial, que se vuelve a dirigir a su facción durante la reclusión forzosa a la que se ven sometidos: «esto no es un motín, yo seguí las reglas». "COB», también aprisionado por fidelidad a Hunter, le manifiesta sus dudas: «la mitad de mí celebra el retorno del comandante, puede tener la razón». El personaje del contramaestre pivota entre las dos fuerzas en el Alabama constantemente, pero será guiado por el argumento de Hunter en el último tercio de la historia. 


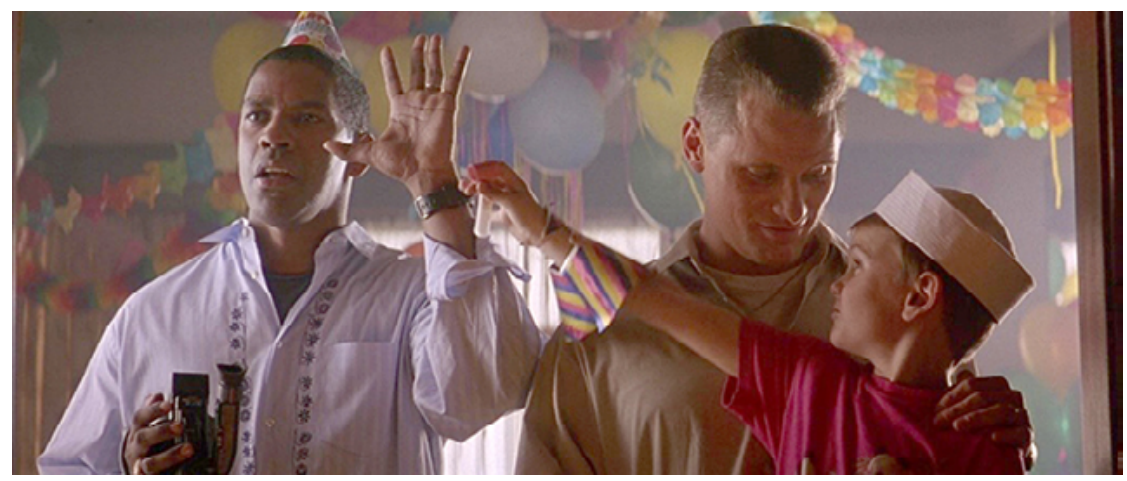

Fig. 15. Hunter y «WEPS» durante la escena de la fiesta de cumpleaños. Crimson Tide (Tony Scott, 1995). Hollywood Pictures y Don Simpson / Jerry Bruckheimer Films.

\subsection{CONCILIO Y REDENCIÓN}

El comandante Richardson es testigo de su propia caída en Run Silent Run Deep, pero, finalmente, consigue su objetivo gracias al entendimiento con Bledsoe, que se apropia de la determinación de su capitán tras sobrevivir al ataque enemigo y al detectar posibilidades de éxito en el contraataque. De esta manera, la superación del antagonismo entre ambos se soluciona a través de un sentimiento compartido por eliminar al agresor. Richardson, correspondiendo a la dinámica de relación paternal y edípica entre ambos, reconoce en privado al primer oficial que confiaba en su valentía: «tuve el presentimiento de que su orden de retirada no llegaría a cumplirse».

De esta manera, Richardson resulta ser un inesperado maestro para el primer oficial, y este aprenderá el valor de la convicción y el arrojo de su superior. Tras la muerte del comandante, una vez proclamado líder del Nerka, Bledsoe es el apoderado para consolidar a Richardson como honorable frente a la tripulación. El nuevo comandante dirige un acto militar de sepultura en el mar y completa de esta manera su licencia para gobernar en solitario, asimilando para sí la lección del comando que Richardson le legó en vida. Durante el acto, Bledsoe lo reconoce mediante un saludo militar por primera y última vez en el momento en que el cuerpo de comandante es enviado a las profundidades del océano ${ }^{29}$.

Para el caso de la película de Scott, el comandante Ramsey es derrotado sin paliativos por la razón de Hunter acerca del mensaje incompleto sobre el disparo de la fuerza nuclear. La tripulación al completo es informada por el propio comandante del contenido de la orden y en ese instante cesa la lucha por el control del Alabama.

29 De igual modo que los restos de Richardson, el comandante Ramsey abandona el microcosmos del submarino mediante un acto de descenso. 


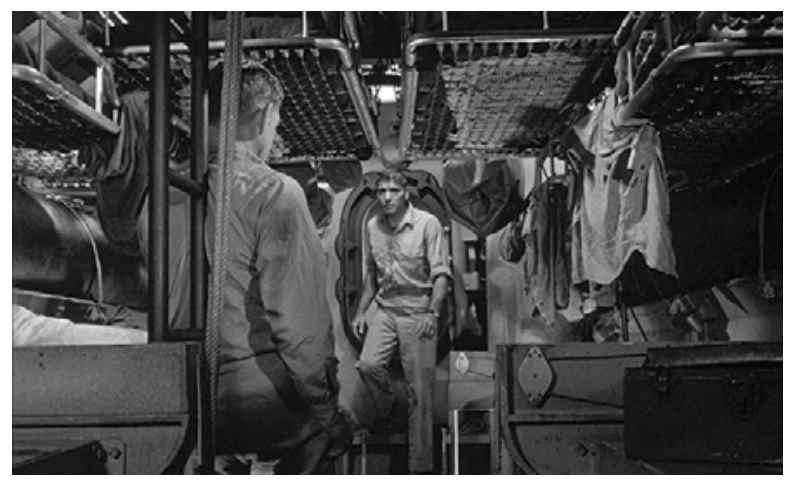

Fig. 16. En último acto de Run Silent, Run Deep, Richardson y Bledsoe acercan posiciones. Run Silent Run Deep (Robert Wise, 1958). Hill-Hecht-Lancaster Productions y Jeffrey Pictures Corp.

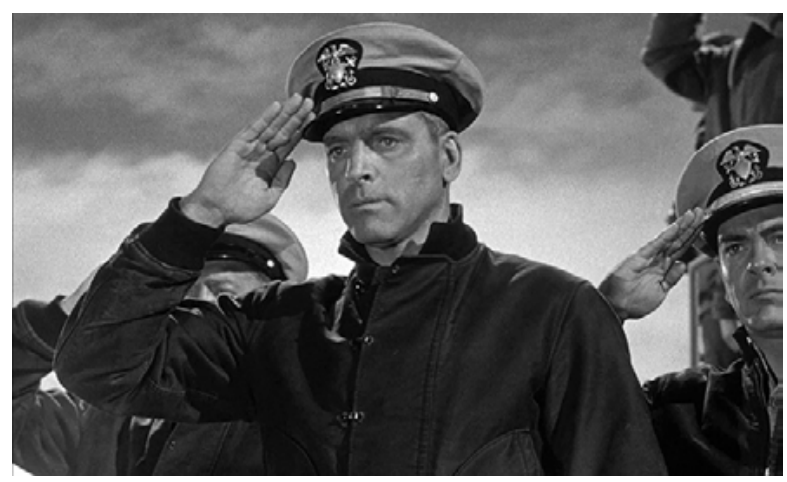

Fig. 17. El nuevo comandante del Nerka despide el cuerpo de Richardson en alta mar. Run Silent Run Deep (Robert Wise, 1958). Hecht-Hill-Lancaster Productions.

A continuación, Ramsey cede el gobierno a su primer oficial para convertirse en un actor irrelevante en el navío.

Como se ha descrito anteriormente, resulta habitual en estos relatos que el cisma del comando se repare al llegar a la conclusión, exhibiendo una buena imagen de la Marina. Este no es el caso de Crimson Tide, quizás el único filme de guerra submarina en el que el comando no llega nunca a resarcir su división (Rayner 2007: 190). Este hecho es remarcado durante la escena de la junta de investigación, donde no se determina una parte como la acertada: «extraoficialmente ambos crearon un lío tremendo. [...] la violación del protocolo de lanzamiento nuclear» ${ }^{30}$.

${ }^{30}$ La exaltación de patriotismo épico durante la escena en la que Ramsey se dirige a su tripulación antes de zarpar el Alabama queda soslayada por la problemática expuesta durante la investigación. 


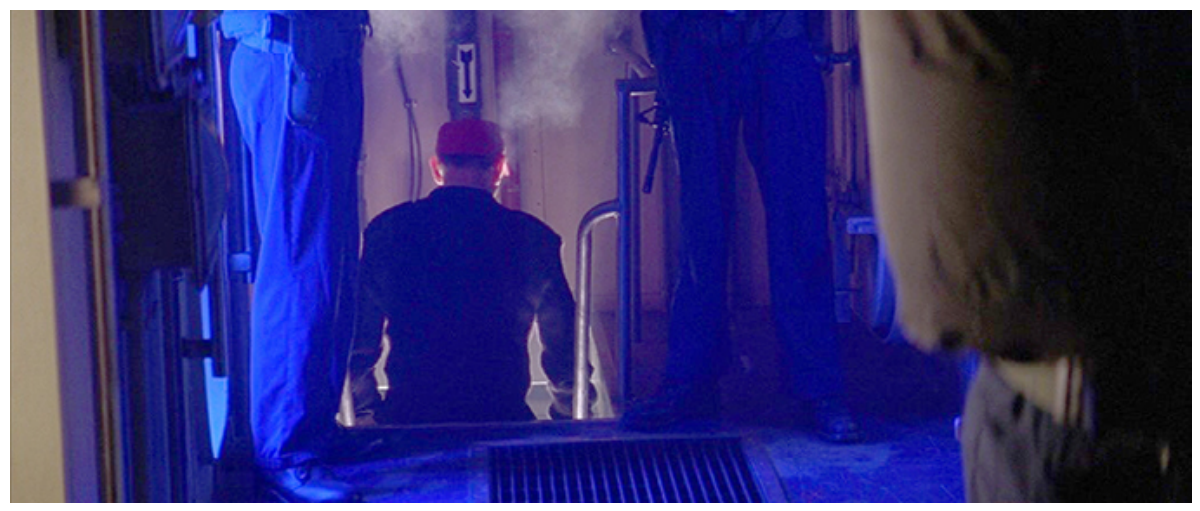

Fig. 18. Ramsey abandona la sala de control del Alabama en un simbólico descenso hacia su cese. Crimson Tide (Tony Scott, 1995). Hollywood Pictures y Don Simpson / Jerry Bruckheimer Films.

A nivel personal, sí se alcanza cierta conciliación en el epílogo de Crimson Tide. Ramsey recomienda a Hunter para ser ascendido a comandante frente al comité investigador ${ }^{31}$ y poco después ambos protagonizan la última escena de la película. El momento está localizado en un soleado espacio exterior, la antítesis del entorno de presión que ha contextualizado todos sus enfrentamientos. Los dos marinos visten uniforme durante la escena, lo que aporta un carácter oficial al encuentro. Hunter da el primer paso para agradecer la intercesión del comandante a su favor: «solo quería darle las gracias», y desciende unas simbólicas escaleras que separan a ambos con la complicidad de la cámara sobre grúa de Tony Scott. Ramsey, a continuación, bromea sobre todo lo ocurrido retomando la primera conversación durante su «entrevista-enlace», y durante el último asalto al poder dentro del Alabama: «usted tenía razón y yo me equivoqué [...] sobre los lipizzanos, son de España y no de Portugal». Hunter responde con una sonrisa irónica, para acto seguido cerrar el encuentro con un saludo militar. Al igual que Run Silent Run Deep, el saludo es símbolo de respeto, pero también anuncia una separación definitiva. Se trata de la despedida de dos hombres con principios opuestos que reconocen una consideración mutua, al mismo tiempo que ratifican como irreconciliable su punto de vista sobre el incidente. Para el espectador, Ramsey ya no se percibe como un villano y el personaje se redime al reconocer el valor y méritos de Hunter.

31 Se consuma la teoría de «impugnación al padre» o «matar al padre» propuesta por Rayner como ejercicio final al acceso del comando por parte del primer oficial. Ello implica en Crimson Tide la jubilación del comandante Ramsey y una tendencia «paternalista» por su parte al reconocer y promover los méritos de Hunter. 

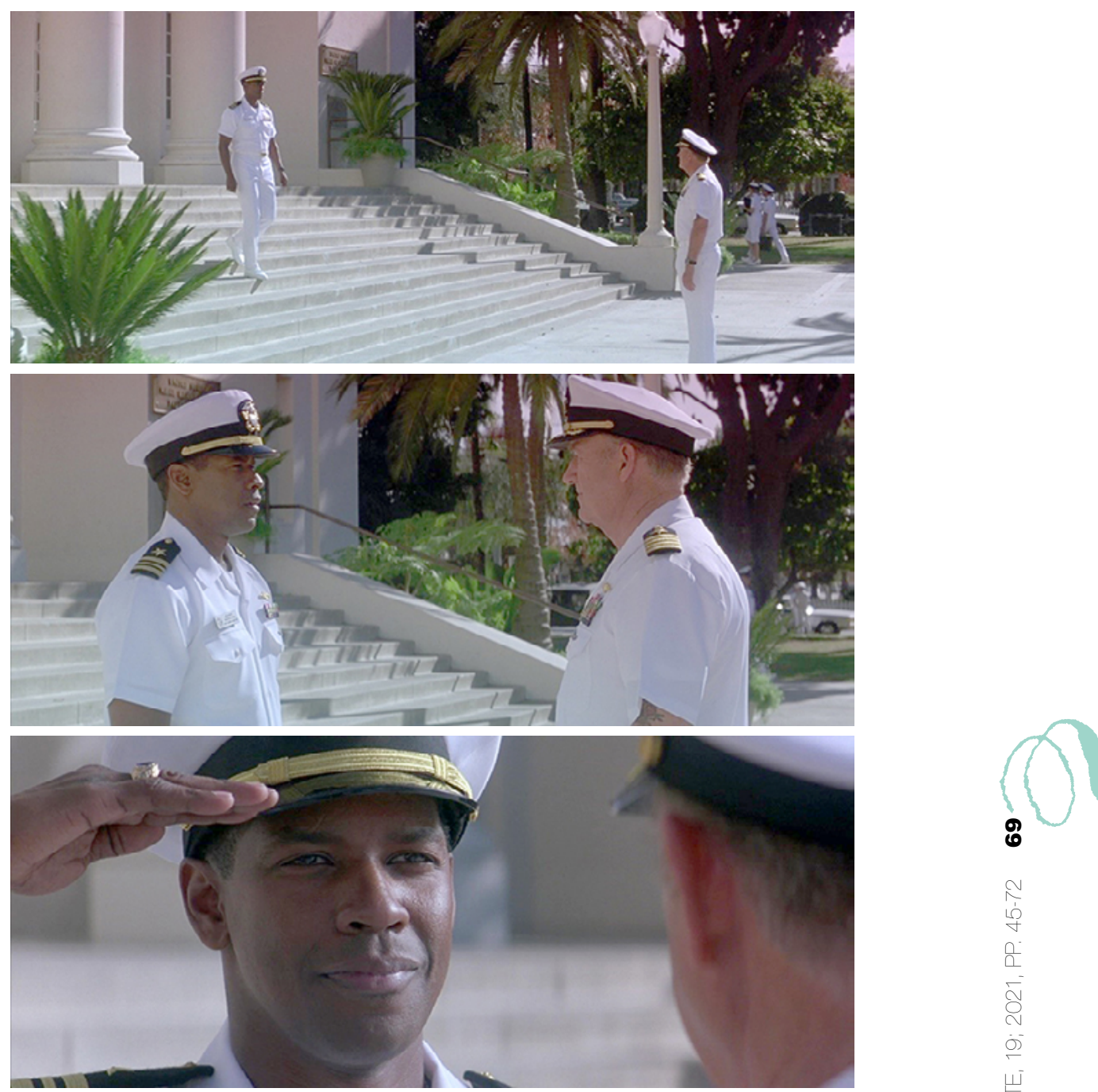

Fig. 19. Secuencia de fotogramas de la última escena de Crimson Tide (Tony Scott, 1995). Hollywood Pictures y Don Simpson / Jerry Bruckheimer Films.

\section{CONCLUSIONES}

Las dos películas estudiadas establecen la relación antagónica entre sus personajes protagonistas desde las primeras escenas que comparten en pantalla. El disentimiento motivado por conflicto ideológico o por disputa ya es manifiesto antes de las patrullas, para, a continuación, trasladarse al ejercicio de gobierno de las naves submarinas y agravarse en un entorno hostil, de confinamiento y en estado de guerra. En este sentido, la intensidad de estos incidentes se determina en gran parte por 
la capacidad destructiva que tiene cada buque según la hipótesis de Koldau. Para el caso de Crimson Tide, al ubicar la historia en un submarino estratégico nuclear con una capacidad de fuego inimaginable, se incrementa considerablemente el factor de desestabilización del comando.

En lo que concierne a la habitual restauración de la buena imagen de la Marina en la conclusión de las películas de guerra submarina norteamericanas con la temática de la crisis de comando, como ocurre en Run Silent Run Deep, puede observarse su opuesto en Crimson Tide. La película de Scott, a pesar de hacer gala de instantes de un patriotismo entusiasta, no resuelve nunca el fallo del comando respecto al uso del armamento nuclear y únicamente se alcanza un concilio satisfactorio a nivel personal. Por consiguiente, la Marina de los Estados Unidos no pudo revalidar la visión idealizada del arma submarina nuclear que esperaba a cambio de su cooperación, que finalmente no se llevó a cabo. A pesar la leyenda que aparece en pantalla en los créditos finales sobre la actualización del decreto respecto a la orden de disparo, el descrédito a la buena praxis en un submarino norteamericano nuclear visto en Crimson Tide queda patente y da pie a un debate antibelicista del que Run Silent, Run Deep carece.

La realidad de la guerra nuclear es un escenario que cambia la estrategia argumental de la crisis del comando en el cine de guerra submarina norteamericano. Al contrario de lo que ocurrió tras la Segunda Guerra Mundial, el cine producido en la era post Guerra Fría ya no es capaz de trasladar el modelo de relato sin consecuencias en su relación con las fuerzas armadas. No obstante, el atractivo comercial que supuso un duelo interpretativo de estrellas de cine de Hollywood demostró ser suficientemente sugerente para prescindir de la cooperación. Pese a ello, no se ha vuelto a estrenar una película norteamericana sobre la crisis del comando en submarino nuclear de la Marina de los Estados Unidos desde el año 1995. 


\section{REFERENCIAS}

Ferro, Marc. 1995. Historia contemporánea y cine. Madrid: Editorial Ariel.

Koldau, Linda M. 2012. Reprasentätionen des Krieges. Göttingen: Wallstein Verlag.

KoldAu, Linda M. 2011. «Why submarines? Interdisciplinary approaches to a cultural myth of war». Journal of War and Culture Studies 4: 65-78.

Ketov, Ryurik A. 2005. «The Cuban Missile Crisis as Seen Through a Periscope». Journal of Strategic Studies 28: 217-231.

Mata, Santiago. 2015. U-Boote. El Arma Submarina Alemana durante la Segunda Guerra Mundial. Madrid: La Esfera de los Libros. Edición Kindle.

McKee, Robert. 2002. El guión. Madrid: Alba Editorial.

Nichols, Bill. 2009. «Seven Reasons Why I Love Submarine Movies». The Velvet Light Trap 64:102103.

Rayner, Jonathan. 2007. The naval war film. Manchester: Manchester University Press.

Roвв, David. 2004. Operation Hollywood: How the Pentagon Shapes and Censors the Movies. New York: Prometheus Books.

Rodríguez, Hilario J. 2006. El cine bélico. Barcelona: Ediciones Paidós Ibérica.

Rosentone, Robert A. 1988. «La historia en imágenes/la historia en palabras». The American Historical Review 93: 1174.

Rowan, Terry. 2012. World War II Goes to the Movies \& Television Guide, volume II, L-Z. Morrisville: Lulu Press Inc.

Suid, Lawrence. 2002. Guts \& Glory: The Making of the American Military Image in Film. Lexington: University Press of Kentucky.

Box Office Mojo. 2020. «Crimson Tide». Consultado el 16 de diciembre de 2020. https://www. boxofficemojo.com/title/tt0112740/?ref_=bo_rl_ti.

Box Office Mojo. 2020. «The Hunt for the Red October». Consultado el 8 de diciembre de 2020. https://www.boxofficemojo.com/title/tt0099810/?ref_=bo_se_r_1.

Cinema Blend. 2009. «Interview: Tony Scott». Consultado el 28 de diciembre de 2020. https:// www.cinemablend.com/new/Interview-Tony-Scott-13537.html.

LA RAZÓN. 2019. «Escándalo en un submarino nuclear de EE. UU.: tripulantes confeccionan una lista de violación». La Razón, 18 de mayo de 2019. Consultado el 10 de octubre de 2020. https://www.larazon.es/internacional/escandalo-en-un-submarino-nuclear-de-ee-uu-tripulantes-confeccionan-una-lista-de-violacion-HK23388078/.

Institute of International Studies, UC Berkeley. 1998. «The Wise Touch. Conversations with Robert Wise». Consultado el 4 de diciembre de 2020. http://globetrotter.berkeley.edu/conversations/Wise/wise-con5.html.

Internet Movie Database. 2021. "Quentin Tarantino». Consultado el 14 de enero de 2021. https:// www.imdb.com/name/nm0000233/?ref_=nv_sr_srsg_0.

Internet Movie Database. 2021. «Sort by Popularity - Most Popular Movies and TV Shows tagged with keyword submarine-movie». Consultado el 11 de enero de 2021. https://www. imdb.com/search/keyword/?keywords=submarine-movie. 
Lantern. 2021. «Motion Picture Daily. UA’s Relases Oct-Dec 1958». Consultado el 18 de enero de 2021. https://lantern.mediahist.org/catalog/motionpicturedai84unse_0_0046.

Ryan, Tim. 1995. «Navy wasn't privy to 'Tide'». Reading Eagle, 12 de mayo. Consultado el 3 de enero de 2021. https://news.google.com/newspapers?nid=1955\&dat=19950512\&id=WxkyAAAAIBAJ\&sjid=D6IFAAAAIBAJ\&pg=3632,6592013.

Submarine Force Pacific. 2020. «USS Alabama SSBN 731». Consultado el 26 de noviembrede 2020. https://www.csp.navy.mil/alabama/About/. 


\title{
LA REPRESENTACIÓN DE LA INMIGRACIÓN \\ LATINA EN EL MUSICAL ESTADOUNIDENSE: WEST SIDE STORY E IN THE HEIGHTS
}

\author{
Virginia E. Higueras Rodríguez \\ Universidad de La Laguna
}

\section{RESUMEN}

En un país fundado por emigrantes de origen europeo, y donde el flujo migratorio ha sido una constante desde que en el s. XVII llegaran los primeros colonos, la inmigración más allá de Río Grande se ha considerado siempre como invasora. A través de musicales como West Side Story (1957) e In the Heights (2007), analizaremos el cambio de paradigma que se da en el musical estadunidense con el paso de los años, con respecto a la inmigración latinoamericana.

Palabras clave: inmigración, latinos, Nueva York, musical estadounidense, puertorriqueños, dominicanos.

\author{
THE REPRESENTATION OF LATINO IMMIGRATION \\ IN THE MUSICAL OF THE UNITED STATES OF AMERICA: \\ WEST SIDE STORY AND IN THE HEIGHTS
}

\section{Abstract}

In a country founded by European emigrants, where the migratory flux has never stopped since the first settlers arrived in the 17th Century, the immigration coming from far beyond Río Grande has always been considered as invading. Through musicals like West Side Story (1957) and In the Heights (2007), we will analyze the change of paradigm of the Latino immigration as portrait in the American musical.

Keywords: Immigration, Latino, New York, American musical, Puerto Rican, Dominican. 
En un país fundado por emigrantes de origen europeo, y donde el flujo migratorio ha sido una constante desde que en el s. Xvir llegaran los primeros colonos, la inmigración más allá de Río Grande se ha considerado siempre como invasora, a pesar de que en ocasiones, como es el caso de Puerto Rico, se tratara de un movimiento migratorio hacia la metrópoli colonizadora. En el cine, y en especial en los musicales de mediados de los cincuenta, tenemos representaciones claras del migrante latino como un estereotipo que se ha utilizado durante mucho tiempo para, de alguna manera, demonizar la inmigración asociada a una etnia distinta a la caucásica.

A través de musicales como West Side Story (1957) estableceremos la visión estadounidense de la migración a mediados de los cincuenta, mientras que con obras como In The Heights (2007) descubriremos la realidad de las comunidades latinas que habitan Manhattan ya entrado el siglo xxI. Ambos musicales se aproximan a la problemática que sufren, por un lado, la comunidad puertorriqueña, y por otro, la dominicana, en una gran urbe que se erigía como centro generador del gran sueńo americano. Mientras la visión estadounidense nos presenta a los latinos dentro de una banda que busca establecer su lugar dentro de una sociedad asfixiante, la versión que nos proporciona Lin-Manuel Miranda cincuenta años después es de un colectivo que a pesar de ser parte de la gran manzana, de alguna manera sigue manteniéndose aislada. Esto nos lleva a pensar que, a pesar de la lógica evolución de estas comunidades y la aparición de nuevas generaciones nacidas estadounidenses, la etnia sigue siendo motivo de segregación. Lo que ha generado, aún hoy en día, conflictos entre colectivos que ya poco tienen que ver con el lugar de nacimiento de sus padres y en ocasiones, incluso con el de sus abuelos.

Hablar de inmigración en Estados Unidos es un tema sumamente delicado, ya que, como recoge en el texto de John F. Kennedy A Nation of Immigrants, los inmigrantes que conforman los Estados Unidos son 'blancos', es decir, de procedencia europea. De modo que, a pesar de que Puerto Rico fuera ocupado por estadounidenses y los locales fueran asimilados culturalmente, siguen siendo considerados como inmigrantes en Nueva York. Son migrantes que acuden a la metrópoli en busca de una vida mejor, pero su etnia, su cultura, sus costumbres, en definitiva, su origen, los hacen diferentes a los inmigrantes 'blancos'. Estableciéndose así marcadas diferencias sociales que llegarán hasta nuestro tiempo. Las causas que han propiciado la inmigración en Nueva York son muchas y variadas, dependiendo del estatus social de los propios migrantes, así como situaciones económicas y alteraciones sociales propiciadas por el clima político que se vive en el país de origen. El término inmigrante, siguiendo la definición que proporcionan las autoras Percy Kraly y Miyares, hace referencia a

Extranjeros que son legalmente admitidos en los Estados Unidos con un visado de inmigración para obtener un estatus de residencia permanente [...] estas personas son consideradas como residentes de Estados Unidos. Extranjeros con residencia permanente pueden obtener la ciudadanía estadounidense tras un proceso 
de naturalización, normalmente después de cinco años de residencia en Estados $\operatorname{Unidos}^{1}$ (2001: 35).

\section{PUERTORRIQUEÑOS: DEL CARIBE A 'EL BARRIO’}

Es necesario hacer una revisión histórica para comprender el origen de la migración puertorriqueña, y por qué algunos autores se niegan a denominarla inmigración. Puerto Rico vivió bajo la dominación española hasta 1898, cuando entra en lo que se denomina por los expertos como las primeras cuatro décadas de la dominación imperialista (1898-1940). En estos cuarenta ańos el país va cayendo poco a poco en manos del capital industrial y financiero de Estados Unidos. Y como destaca el escritor Maldonado-Denis, «desde el comienzo de la ocupación norteamericana de Puerto Rico, quedó claro el propósito de la metrópoli de asimilar culturalmente a los puertorriqueños y de hacerlos "buenos norteamericanos"» (1977: 126). Esta asimilación supuso que el inglés se instaurara como vehículo de enseñanza en las escuelas públicas, manteniéndose esta situación hasta 1948. «Dándose el caso absurdo de un país en donde se imponía la enseñanza en un idioma que no era el vernáculo en sus escuelas públicas» (1977: 126).

A mediados de la década de los cuarenta comenzó a producirse un éxodo masivo de puertorriqueńos hacia la metrópoli. «Durante la década de los cuarenta emigraron 150000 puertorriqueńos, mientras que 400000 lo hicieron durante la década de los cincuenta» (1977: 52). Esto supuso que, a mediados de los años cincuenta, había más puertorriqueńos viviendo en Nueva York que en San Juan de Puerto Rico; son considerados puertorriqueños, no sólo los migrantes nacidos en la isla, sino además los nacidos de padres puertorriqueños fuera de ella. Las nuevas generaciones de puertorriqueños nacidos en Estados Unidos que no consiguen aprender español son despectivamente conocidos como 'newyorricans' dentro de la propia colonia puertorriqueña. Generando así una separación interna entre los propios migrantes originales y las nuevas generaciones nacidas en Estados Unidos, que conocen más la isla de Manhattan que la de Puerto Rico.

Este colectivo se asienta en la zona de Manhattan conocida como el East Harlem, también llamada El Barrio por los propios puertorriqueños. Muchos de ellos no salen de este barrio y desempeñan trabajos precarios con lo que todo ello conlleva. Claramente la inmigración procedente de las tierras al sur del Río Grande son considerados de una manera u otra como una raza inferior, como apunta Maldonado-Denis:

En una sociedad racista hasta la médula, los grupos étnicos clasificados como non whites tienen que pagar un precio mucho más alto y costoso que el que tuvieron que pagar los emigrantes de descendencia europea cuando emprendieron el camino de asimilación a la sociedad americana (1977: 93).

\footnotetext{
1 Traducción de los textos originales en inglés realizada por la autora.
} 
Esto lleva a que muy pocos logren regresar a su país de origen, y los que lo consiguen son aquellos que han logrado ascender en la escala social, y regresar a su país enriquecidos y por tanto en una situación económica ventajosa.

\section{DOMINICANOS: NUEVOS INMIGRANTES EN WASHINGTON HEIGHTS}

A diferencia de la migración puertorriqueña, podríamos establecer que la migración masiva de República Dominicana a Nueva York se produce de manera continua, pero cuenta con dos momentos clave en los que los dominicanos abandonan el país hacia Estados Unidos. Por un lado, la primera gran migración masiva se produce entre 1930 y 1960, debido a la instauración y consolidación de una férrea dictadura, que acaba con la muerte violenta del dictador en 1961. La posterior guerra civil, a la que se suma la invasión norteamericana, propicia en mayor medida la salida del país de muchos dominicanos. En un primer momento, como apunta la autora Julissa Reynoso, «la inmigración en 1960 afectó a unas pocas regiones dominicanas y [...] a segmentos rurales y urbanos de clase media, así como a activistas políticos con tendencias de izquierdas en la región de Cibao y Santo Domingo, la capital» (2003: 58). Como se recoge en el texto de Ricourt,

Es una comunidad de clase obrera, trabajadores en servicios y de manera informal, igual que desempleados y personas de color convertidas en nuevos inmigrantes que comienzan a llegar durante los sesenta y nunca han parado de migrar a los Estados Unidos (2016: 7-8).

Veinte ańos más tarde, entre 1980 y 1990, nos encontraremos con el siguiente pico migratorio, momento en el que los dominicanos, sin diferencia de clase social, emigrarán debido al deterioro de la situación económica en la isla. A pesar de que encontramos en esta época una nueva oleada de migrantes, la realidad es que el flujo de dominicanos no cesa desde que comenzó a principios de siglo. Esta situación se ve reforzada a mediados de la década de los sesenta por la reforma en la ley de inmigración de Estados Unidos.

Desde la reforma en Estados Unidos de la ley de inmigración en 1965², los dominicanos han constituido un importante componente en el flujo de 'nuevos migrantes' a Estados Unidos. El aumento en los números de dominicanos, principalmente en el gran centro urbano de Nueva York, ha creado lo que constituye comunidades de nuevas etnias y multiétnicas (2003: 58).

Con esta nueva reforma judicial, Nueva York se convierte el principal receptor de los migrantes llegados de Latinoamérica, y para finales de la década de los noventa, la población de esta ciudad estaba conformada por más extranjeros que

${ }^{2}$ Donde se abolen las tasas que deben pagar las inmigrantes, basadas en su país de origen. 
nacionales. Como ocurre con la mayoría de los migrantes, los dominicanos conforman un colectivo de escasos recursos que se ve abocado a realizar trabajos precarios. Pero a diferencia de otras comunidades procedentes de Latinoamérica, como apunta Reynoso, los dominicanos son un grupo que «tiende a concentrarse más, residiendo exclusivamente en barrios o guetos como Washington Heights-Inwood» (2003: 60).

Aun procediendo de distintos puntos del Caribe, la migración tanto puertorriqueña como dominicana se ve afectada en gran medida por la explotación capitalista, por parte de los Estados Unidos, de los recursos naturales de las islas. Esto lleva a que la población emigre, siendo expulsada por un país que más tarde los segregará al intentar rehacer su vida manteniendo las costumbres propias de sus países de origen. La isla de Manhattan se convierte ahora en un centro neurálgico donde florecerán estas comunidades, separadas étnicamente, y segregadas en barrios de las afueras.

\section{LAS COMUNIDADES LATINAS EN EL MUSICAL ESTADOUNIDENSE}

El cine musical estadounidense ha sido considerado como el género escapista por excelencia. Atendiendo al desarrollo del cine musical, a lo largo de la década de los treinta vivió lo que conocemos como su época dorada, con los grandes musicales de Fred Astaire y Ginger Rogers. Por aquella época las tramas eran sencillas, generalmente historias de amores truncados. Según nos acercamos a la década de los cincuenta, el género va decayendo, hasta que, con la caída del sistema de estudios, y las crisis económicas en las que se vieron sumidos debido a grandes superproducciones, poco queda de los musicales originales creados para la pantalla. Es en este momento cuando Hollywood se alimenta de los musicales que en la década anterior se habían puesto en escena en los teatros neoyorkinos, veremos así adaptaciones de obras como My Fair Lady (George Cukor, 1964) o West Side Story (Robert Wise, 1961).

En un momento en que las preocupaciones políticas y sociales se cernían sobre una población que veía como las políticas exteriores se tambaleaban influidas por la Guerra Fría y la Guerra de Vietnam, los filmes musicales que llegaban a la pantalla poco tenían que ver con esta nueva realidad. En pleno desarrollo del movimiento hippie, donde se promovía el amor libre y la juventud se rebelaba en contra del sistema establecido, nada de esto lograba llegar a las pantallas, las tramas seguían reproduciendo los estereotipos de una sociedad que ya poco tenía que ver con ellos. Como apunta la autora Stacy Wolf, «El musical es una convención popular que debe satisfacer los deseos y las expectativas de la audiencia de clase media, uno debe esperar sólo tramas escapistas, agradables, aparentemente apolíticas y representaciones estereotípicas [...] y en ocasiones este es el caso" (2011: 12).

Este es el caso de obras como West Side Story, representado por primera vez en los teatros de la costa este en 1957, donde se hace visible la problemática de los inmigrantes en Nueva York. Sin embargo, un musical que podría haberse convertido en testigo de su tiempo perpetúa los estereotipos que aún hoy en día persiguen a las comunidades migrantes de la ciudad. Podríamos entender que los autores de esta 
obra, el compositor Leonard Bernstein (1918-1990), el letrista Stephen Sondheim (1930) y el coreógrafo Jerome Robbins (1918-1998), que dieron forma al libreto de Arthur Laurents (1917-2011), pretendieran plasmar la realidad que vivían las comunidades extranjeras llegadas a Nueva York en décadas pasadas, pero su origen eminentemente estadounidense los llevó a crear estereotipos de los que se sirvieron para crear esta adaptación de Romeo y Julieta de William Shakespeare.

En contraposición, y con la perspectiva del tiempo, cincuenta años más tarde pisaría las tablas el musical In the Heights, de un joven compositor, autor y letrista, Lin-Manuel Miranda (1980), de origen puertorriqueño. En esta ocasión, nos encontramos con una aproximación mucho más realista a la comunidad dominicana de Nueva York. Los estereotipos del latino, del inmigrante, que aún hoy en día se mantienen casi inalterados, comienzan a romperse para de alguna manera retratar la realidad de un colectivo que, habitando en Washington Heights (Manhattan, Nueva York), pareciera que siguen viviendo en su isla.

Sin pretenderlo, estos dos musicales separados cincuenta ańos en el tiempo retratan las dos caras de una realidad migratoria a la que Estados Unidos se ha enfrentado desde finales del siglo XIX. Hoy en día sigue siendo un tema que en muchas ocasiones se retrata de manera maniquea, evitando así dotar de peso una situación sociopolítica presente en un país que desde la llegada de los primeros colonos en el siglo XVII no ha parado de recibir extranjeros en busca del sueño americano.

\subsection{WEST SIDE STORY}

Este musical, con libreto de Arthur Laurents y basado en la obra de Shakespeare, narra la historia de dos bandas juveniles, los Jets y los Sharks, y su lucha por el territorio en el Upper West Side neoyorquino. María, de origen puertorriqueño y hermana de Bernardo, líder de los Sharks, se enamora de Tony, de origen polaco y además el líder de la banda contraria. Y a pesar de que en un primer momento podríamos esperar que el amor todo lo puede, y las diferencias raciales no son tan importantes como la pertenencia a distintos grupos sociales, el romance entre María y Tony instiga una fuerte oleada de violencia entre las dos bandas. Esta se suma a la paz tensa que viven ambos colectivos, estallando en un sinsentido en el que se pretende establecer la supremacía de una comunidad frente a la otra. Esta fue la versión que llegó a los escenarios y posteriormente a la pantalla; sin embargo, la idea original del coreógrafo Jerome Robins era completamente distinta. Esta obra nace como una propuesta del coreógrafo, que hacia finales de la década de los cuarenta le sugirió al compositor Leonard Bernstein la creación de un musical en el que la coreografía tuviera el mismo peso que las canciones. Para ello pensó que la mejor opción sería adaptar la universal historia de amor de William Shakespeare. Pero esta iba a estar situada, como se apunta en el texto del compositor y periodista Kenneth LaFave, en el Nueva York contemporáneo;

En un inicio iba a desarrollares entre la comunidad irlandesa católica y los inmigrantes judíos durante la celebración de la Pascua Judía. En la visión inicial de 


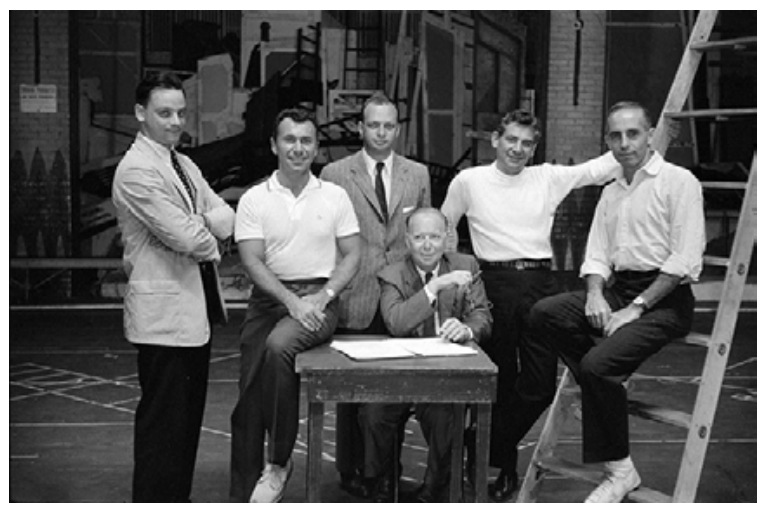

Imagen 1. Stephen Sondheim, Arthur Laurents, Harold Prince, Robert E. Griffith, Leonard Bernstein y Jerome Lawrence en los ensayos para la producción teatral de West Side Story.

Robins dos jóvenes pertenecientes a estas religiones y etnias totalmente opuestas, se enamoran a pesar de la antipatía entre ambas culturas (2015: 119).

Sin embargo, este primer borrador fue olvidado con el tiempo, ya que se dieron cuenta de que estaban repitiendo la trama de una popular comedia que había sido un éxito en los escenarios de Broadway con anterioridad, Abbie’s Irish Rose (1922). No sería hasta mediados de los cincuenta cuando retomarán el proceso creativo y el musical tomará la forma con la que lo conocemos en la actualidad. Debido al aumento de la llegada de inmigrantes puertorriqueños a Nueva York y los crecientes conflictos que se estaban viviendo en el West Side, decidieron desarrollar la trama en torno a la problemática de esta comunidad y los enfrentamientos entre las distintas bandas que se habían generado en la ciudad. Tardarían siete años en desarrollar el musical teatral y una vez estrenado en Broadway, tardarían cuatro años en realizar la adaptación cinematográfica.

West Side Story narra la historia de amor entre Tony y María, y con ella visibiliza la situación en la que se encontraban estos colectivos de inmigrantes en la ciudad. Muchos de los jóvenes migrantes intentan integrarse en la sociedad sin tener en cuenta su origen, su cultura o el color de su piel, buscando dejar atrás el aislamiento que se genera dentro de estas comunidades, celosas de perder sus orígenes. El amor imposible entre un polaco y una puertorriqueña hace que las bandas, que ya estaban enfrentadas por el dominio del territorio del barrio, defiendan a sus integrantes, intentando separarlos. El desenlace de las disputas surgidas a raíz del romance entre María y Tony acaba con un episodio violento en el que Bernardo mata a uno de los Jets y como respuesta, Tony se ve forzado a entrar en la pelea, acabando con la vida de este. Por ello y como venganza, Chino mata a Tony, aprovechando que se encuentra solo en la noche para ver a María. Una vez que este trágico episodio concluye y vemos a una María destrozada por el dolor de haber perdido tanto a su 


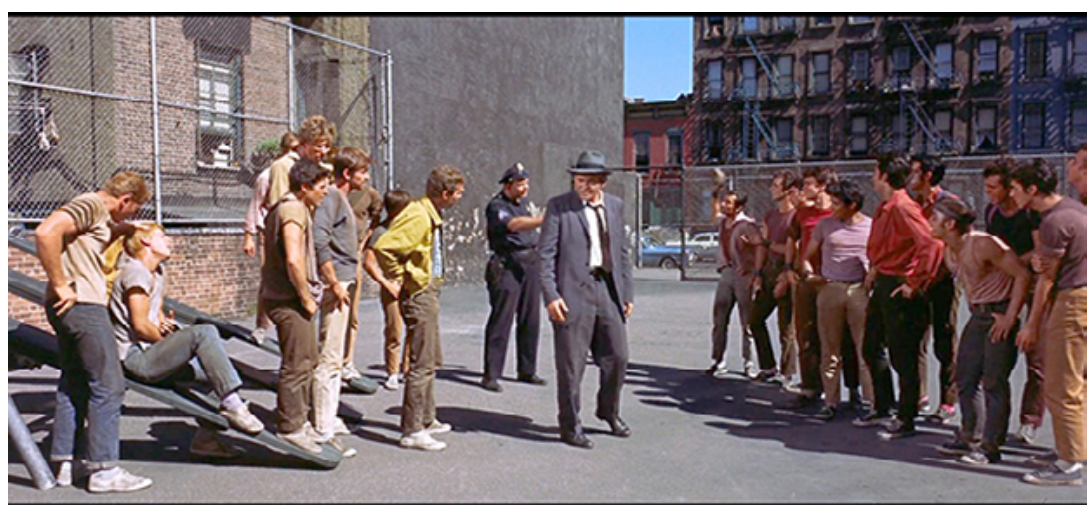

Imagen 2. Fotograma de la película. Enfrentamiento entre los Sharks y los Jets.

hermano como a su amor, los integrantes de ambas bandas reaccionan, uniéndose para llevar el cuerpo sin vida de Tony dejando a un lado sus diferencias. En un final ideal de Hollywood, los malos actos deben ser castigados, y como Tony ya ha muerto, sólo queda darle un final a Chino.

Como recoge el autor Stavans,

West Side Story se desarrolla en un barrio pobre, radicalmente diverso del West Side, donde los puertorriqueńos son la minoría [...]. A pesar de que la policía está detrás de las dos bandas del barrio, la obra no trata de manera equitativa a las distintas facciones, desde el principio. Los puertorriqueños son acosados, ofendidos $\mathrm{y}$ atacados verbalmente por la autoridad [...]. Esta adaptación musical es sobre la tragedia de los estereotipos raciales en una turbulenta metrópoli (1999: 46).

Esta sensación de disparidad ente las bandas se intensifica no sólo por la diferencia entre «apariencia, sonidos, movimientos o vocabulario» (2011: 97) que acompañan los números de cada una de ellas. «Los dos grupos aparecen juntos sólo en el número "El baile en el gimnasio" (2011: 97), donde se deja ver a través de la coreografía de Jerome Robbin como, a pesar de estar enfrentados, los jóvenes tienen los mismos deseos e impulsos. Este número es el único en el que todos bailan la misma música y reproducen la misma coreografía, dando una sensación de unidad que se rompe sólo por las diferencias estéticas ente los colectivos.

Al tratarse de una producción en la que lo visual predomina sobre la canción o incluso el diálogo, se utilizan los colores como distintivos de las bandas. Mientras que los puertorriqueños visten colores llamativos y alegres utilizando rojos, violetas y fucsias, los polacos se mantienen en la gama de los amarillos y los naranjas, reservando el blanco tanto para María como para Tony. Muestra de ello es la primera imagen que tenemos de Bernardo, que se presenta con una camisa roja sobre una pared del mismo color. Esto nos permite distinguir en los enfrentamientos a los integrantes de cada banda. Color que llevará también María al final del filme, dejando 

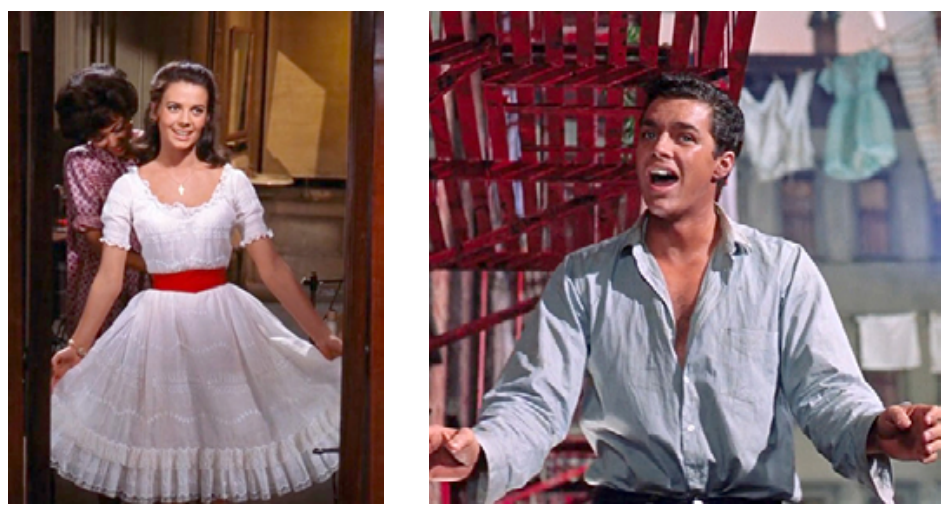

Imágenes 3 y 4 . María y Tony al inicio de la película.

claro sus raíces puertorriqueñas. A lo largo de la película, María, que comienza vistiendo de blanco con sutiles toques rojos que la incluyen visualmente dentro del colectivo puertorriqueńo, irá combinando colores, llegando a vestir de amarillo y naranja, identificativos de la banda de Tony.

En cuanto a las canciones, a pesar de encontrarnos ante un musical que explora el conflicto entre las comunidades inmigrantes de Manhattan, de alguna manera se pone el foco sobre la vida del puertorriqueño, explorando sus inquietudes y su necesidad de pertenencia a Estados Unidos. Es quizás el tema America uno de los más reconocibles de su banda sonora, y es este donde se pone de manifiesto la diferencia entre los inmigrantes blancos y los inmigrantes procedentes del sur del continente. Un diálogo previo al inicio de este número pone de relevancia cómo los blancos nacidos de padres inmigrantes, como es el caso de Tony, ya son americanos, mientras que los puertorriqueños no dejan de ser puertorriqueños.

La vida está bien en América

Cuando eres un blanco en América.

Es precisamente esta canción la que nos permite vislumbrar la situación que está viviendo la población en Puerto Rico, y los motivos que los hacen salir de la isla. Es también en este número cuando vemos las dos posturas del inmigrante, por un lado tenemos a los hombres que desean volver a sus orígenes, mientras que las mujeres cantan las bondades que viven en Estados Unidos y su deseo por convertirse en mujeres estadounidenses.

Puerto Rico,

[...]

Siempre los huracanes soplando,

Siempre la población creciendo,

Y debiendo dinero. 
Leonard Bernstein, sirviéndose de ritmos latinos, y Stephen Sondheim, utilizando palabras y términos propios del colectivo puertorriqueño, nos transportan en números como este a la calurosa isla del Caribe, que se describe como un lugar donde la población no tiene medios para salir adelante. Este tema gira en torno a la idea idílica del sueńo americano al que aspiran todos los inmigrantes llegados a Nueva York, su necesidad de ser parte de esta nueva sociedad, gozando de todas las libertades de las que un ciudadano nacido estadounidense goza. "Los personajes masculinos descendientes portorriqueños son machos anhelando una vida sin tantos riesgos en el trópico, mientras que, las mujeres de manera uniforman entienden el desafío del Sueńo Americano» (46).

Me gusta la isla de Manhattan-

[...]

Libre para elegir lo que se.

Aquí eres libre y estás orgulloso.

Es esta libertad la que ansía conseguir María, desde una de sus primeras líneas de diálogo en la que se define como una joven americana y no puertorriqueña. Este sentimiento de pertenecía a un nuevo país, a una nueva cultura, se explora de manos de la hermana más joven de la comunidad. María se siente integrada en una sociedad en la que su hermano Bernardo sólo encuentra problemas. Quizás por miedo a separase de sus orígenes, teme ser completamente asimilado por la ciudad, y sigue luchando por demostrar que esta comunidad tiene su lugar en un pequeño barrio de Manhattan. Podríamos definir a Bernardo como el estereotipo latino masculino, fuerte y pasional, que necesita demostrar continuamente su posición como líder de la banda. Mientras en Tony, al ser un inmigrante blanco, pasa casi desapercibido, es un chico normal, trabajador que evita los conflictos, a pesar de ser considerado el líder de los Jets.

En cuanto a las mujeres, podríamos decir que Anita, novia de Bernardo, perpetúa el estereotipo de mujer latina, a diferencia de María, a la que podría considerarse, como apunta Wolf, como «la protagonista soprano romántica, la chica ingenua, o la chica corriente» (2011: 29), Anita es «la mujer fuerte y dominante» (2011: 29). La matriarca latina que se enfrenta a los hombres sin demasiados problemas. Además, es a ella a la que vemos trabajar y no a Bernardo, lo que nos indica la fortaleza de este personaje, que llega a Nueva York para buscar un futuro y cada día lucha por él. Anita manifiesta la intención de quedarse en este nuevo país e integrarse, sin renunciar a sus raíces, a pesar de ser cuestionada por su pareja, Bernardo.

A pesar de la aparente sencillez de la trama principal, este musical explora los conflictos intergeneracionales que fueron aflorando en los años cincuenta. Es en este momento cuando los jóvenes que se convertirían en los padres de las primeras generaciones de puertorriqueños-estadounidenses intentan integrarse en una sociedad que empezaba a disfrutar de un estado del bienestar. Quedando patente una clara diferencia entre las generaciones de migrantes, mientras los adultos intentan no perder el contacto con sus orígenes, los jóvenes ansían explorar la nueva cultura en la que se encuentran. Como apunta el compositor y escritor Peter E. Grandenwitz, «En West Side Story las bandas callejeras no sólo luchan entre ellas, sino que también 


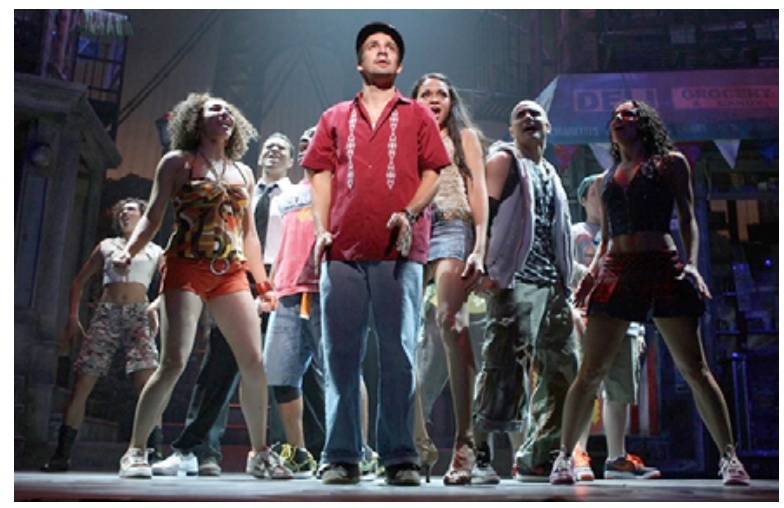

Imagen 5. Lin-Manuel Miranda y el reparto original de Broadway de In the Heights.

se rebelan contra la sociedad [...]. Éste no era un espectáculo creado simplemente para entretener con una historia romántica y música animada, sino para remover conciencias, mostrando la tragedia y lucha» (1987: 186-187).

\subsection{IN THE HEIGHTS}

Cincuenta años después de la aparición de la obra musical West Side Story, se estrena el primer musical que habla sobre la inmigración latina, escrito y compuesto por Lin-Manuel Miranda, nacido en Nueva York de padres puertorriqueños. Protagonizado por un reparto de actores también de origen latino. Podríamos encontrar similitudes entre ambos musicales, como apunta la autora Stacy Kent:

Recuerda a West Side Story porque [...] una de las tramas principales se construye en torno al romance entre personajes de culturas diferentes [...]. Además, In the Heights, como West Side Story, utiliza el baile como principal forma de comunicación, y transmite de igual manera el carácter emocional y volátil de los jóvenes que se expresan de mejor manera bailando (2011: 189).

La diferencia principal entre ambos musicales es que, no sólo nos encontramos con una historia de amor que pone a prueba las diferencias culturales, sino que además narra la realidad contemporánea de los nacidos de inmigrantes en Nueva York. Se aleja de intentar establecer diferencias entre grupos, y nos hace una radiografía del colectivo dominicano en la isla de Manhattan, rompiendo los estereotipos creados en torno a los ciudadanos con raíces más allá de Río Grande.

In the Heigts es un musical coral que recuerda a las producciones que empezaron a verse sobre las tablas de los teatros Off-Broadway a mediados de la década de los noventa. Encontrando similitudes que lo acercan a obras como Rent (Jonathan 
Larson, 1996), ya que no se centra en el desarrollo de una sola línea argumental, sino que nos da a conocer diferentes realidades dentro del mismo colectivo, cruzando las historias y enriqueciendo la narración. Este musical nos lleva al barrio de Washington Heights, donde los latinos se están viendo afectados por la gentrificación y muchos de ellos se ven obligados a salir del barrio que los ha visto crecer. Como ocurre en Rent, veremos la evolución de los personajes a lo largo de un periodo de tiempo indeterminado, que nos lleva hasta el momento en el que muchos de ellos deciden abandonar las calles de este barrio de Manhattan.

Como apunta Wolf, este musical está plagado de fórmulas correspondientes al musical clásico, por un lado nos encontramos ante el típico musical de grandes números, donde apenas hay diálogo y, cuando lo hay, sigue siendo parte de las canciones o es recitado. Esto nos recuerda a las óperas rock que nacen en los años setenta, con la única diferencia de que en este caso escuchamos ritmos latinos. Por otro lado, las dos historias de amor que se desarrollan a lo largo de la trama recuerdan a aquellas escritas por Rodgers and Hammerstein en musicales como El rey y yo (1951), Cenicienta (1957) o Sonrisas y lágrimas (1959). Además, en Usnavi, encontramos la figura del narrador que también está presente en El violinista en el tejado (Joseph Stein, 1964). En el caso de este último, Tevye, el protagonista, narra las desgracias del pueblo judío en los límites del territorio ruso, que se ven obligados abandonar Anatevka por sus creencias. En el caso de In the Heights lo que obliga, de alguna manera, a sus residentes a salir del barrio son los continuos conflictos, costes de suministro y vandalismo que sufren. Esto, acompañado de un gasto en escenografía y atrezo reducido, llevó a que esta historia sobre la comunidad latina, creada y contada por latinos, fuera producida y considerada como económicamente viable para trasladarla a los escenarios de Broadway.

El compositor y letrista Lin-Manuel Miranda, que empezó a escribir este musical en su segundo año en la Universidad Wesleyana, cita todas estas influencias. Rent fue el primer musical que vio que se desarrollaba en el presente, lo que le permitió escribir un musical sobre su propia vida y sus experiencias (2011: 189).

El tema principal de este musical podríamos decir que es el hogar, el lugar donde todos sus protagonistas se sienten seguros. Y para ellos, el barrio es su hogar, aunque tengan que dejarlo llegado el momento. Nos adentramos en esta realidad de la mano de Usnavi, que, como narrador, nos lleva a conocer, a través de coreografías y ritmos latinos, el barrio de Washington Heights, situado en el norte de la isla de Manhattan. Usnavi nos presenta la vida diaria de un barrio, en mitad del asfixiante calor del verano neoyorkino, donde parece que nada cambia, así como a sus principales habitantes. Nos sitúa así en la realidad sofocante de un hijo de inmigrantes, cuyo nombre se debe a las letras pintadas sobre un barco atracado en el puerto de Nueva York, cuando sus padres llegaron a la isla de Manhattan. A partir de este momento y una vez que conocemos el barrio y sus gentes, se desarrollan dos líneas argumentales principales. Por un lado nos encontramos con la llegada de Nina tras haber estado en la universidad, que se enamora de un chico puertorriqueño al que conoce desde la infancia. Su romance, como el de María y Tony, estará lleno de 

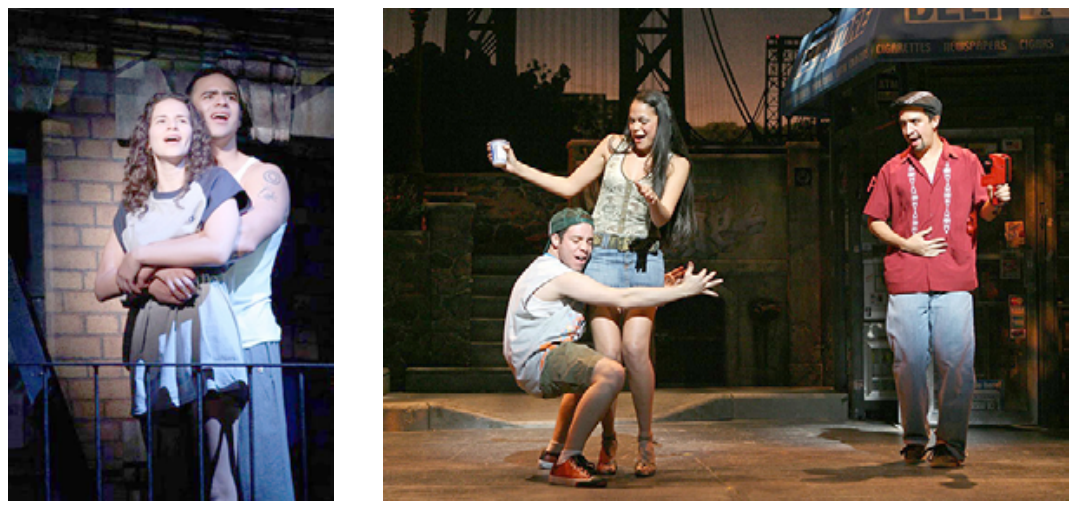

Imágenes 6 y 7 . Vanessa y Nina.

obstáculos que desaparecerán hacia el final de la obra. Con la aparición de Nina, este musical rompe en uno de los primeros números musicales, el estereotipo de la mujer inmigrante, y vemos en ella una joven intelectual que lucha por su futuro. La otra pareja sería la formada por Usnavi y Vanessa; a diferencia del macho latino que representa Bernardo en West Side Story, Usnavi es el chico sociable que conoce a todos en el barrio, pero que en presencia de Vanessa se vuelve tímido. Vanessa, cuyo aspecto podría llevarnos a pensar que se trata de la típica representación de la mujer latina y sexi, desmonta este estereotipo tan pronto como conocemos sus intenciones de salir del barrio y montar su propio negocio, con el que poder prosperar.

En esta obra destacan los personajes femeninos sobre los masculinos, se presenta una comunidad que es principalmente matriarcal y que ha crecido en torno a la figura de Abuela Claudia. De la misma manera, nos encontramos con la madre de Nina, Camila, que representa a la madre latina, que defiende la unidad de la familia y no duda en tomar las riendas de su hogar ante un momento de debilidad. Esto se refleja perfectamente en la canción Enough, en la que, tras una disputa entre padre e hija, Camila deja clara la importancia de la familia.

Cuando tienes un problema vienes a casa

Mientras estemos vivos, nunca estarás sola.

Con estos dos modelos femeninos, las dignas sucesoras son Nina y Vanessa, que viviendo en una comunidad donde la mujer tiene su lugar, no depende de las figuras masculinas a su alrededor. De la misma manera, Vanessa deja claro en su canción It won't be long now que la actitud machista de algunos hombres, como silbar a las mujeres en la calle, no la desaniman a segur su camino.

Su orgullo masculino no rompe mi ritmo

Es un piropo, o eso dicen

Los chicos en mi camino 
Gritan todos los días pero no me importa.

[...]

Un día, subiré en una limusina y me marcharé.

Como ya hemos comentado con anterioridad, este musical pone de manifiesto el orgullo latino y así queda patente en las canciones. Todas ellas celebran la diversidad del barrio, mezclando muchas veces el español y el inglés, transmitiendo así el bilingüismo que se genera en estas comunidades que conservan su lengua vernácula. Uno de los mejores ejemplos lo encontramos en la canción Carnaval del barrio, donde se canta a la diversidad cultural y a la igualdad que existe entre las comunidades que habitan en Washington Heights.
Alza la bandera
La bandera dominicana
Alza la bandera
La bandera puertorriqueña
Alza la bandera
La bandera mejicana
Alza la bandera
La bandera cubana.

Como en el caso del musical previamente mencionado, In the Heights ha sido recientemente adaptado cinematográficamente. Trece ańos después de su estreno en Broadway, nos encontramos una nueva relectura de este musical que marcó un hito con su estreno. In the Heights fue una formula novedosa, ya que no sólo fue una historia de latinos contada por latinos, sino que se convirtió en un movimiento político de visibilización de estos actores dentro de la comunidad teatral. Muchos de ellos han quedado siempre relegados a papeles secundarios, y en muy contadas ocasiones son los protagonistas de historias de éxito. Lin-Manuel Miranda ha continuado dándoles voz a estos actores en una de sus producciones más recientes, Hamilton (2015).

La diferencia principal que encontramos entre la reciente adaptación fílmica y el musical teatral es que esta nueva relectura, realizada entre los años 2019 y 2021, tiene un marcado carácter político-social. Aquí se ponen de manifiesto las dificultades que se encuentran los nacidos de inmigrantes en un país que todavía no los acepta como ciudadanos de pleno derecho. En esta se presta especial atención al personaje de Nina, que se erige como un rara avis dentro de la comunidad. En ella parecen estar puesta todas las expectativas, ya que es la primera en acudir a la universidad. Nina, que había abandonado a la comunidad para estudiar en la costa oeste del país, regresa buscando recuperar el sentido de pertenencia y la protección que le proporciona formar parte de una comunidad. Esto se ve reflejado en el desarrollo del personaje a lo largo del filme. Mientras que la inseguridad la devuelve a la comunidad convertida en un modelo de joven estadounidense, según avanza la película va reconectando con sus raíces. Esto se puede observar en la evolución de su vestuario y su aspecto, pasando, por ejemplo, de un pelo perfectamente liso al inicio a un pelo rizado que recuerda a las mezclas étnicas que se dan en las islas del Caribe. 
A través del personaje de Nina, nos acercamos a la problemática que viven los hijos de migrantes que tratan de acceder a la educación superior, poniendo de manifiesto que se siguen perpetuando estereotipos que sitúan al latino entre las cotas más bajas de la sociedad. Por otro lado, nos encontramos a otro personaje, que cuenta con un mayor desarrollo en la adaptación cinematográfica que en la versión teatral se trata de Sonny, sobrino de Usnavi, cuyas expectativas educativas son mucho mayores que las de la primera generación de migrantes. Siguiendo los pasos de Nina, quiere acceder a la universidad una vez que termine los estudios secundarios, intención que se ve coartada en el momento en el que se pone de manifiesto que no tiene la nacionalidad estadounidense. Es precisamente este incidente el que devuelve a Nina el propósito de terminar sus estudios y convertirse en una defensora de los derechos de los latinos en el que se ha convertido en su país.

El retrato que hace esta película de la sociedad latina dista mucho de la que encontramos representada en West Side Story. En los primeros diez minutos del filme, se nos presenta a una sociedad trabajadora y dedicada con aspiraciones y sueños que les permitan mantenerse en un barrio cada vez más gentrificado. En esta historia donde se incluyen inmigrantes dominicanos, puertorriqueños, cubanos, mexicanos, chilenos y argentinos, compuesta, protagonizada y dirigida por estadounidenses de origen latino, no se genera un discurso de segregación debido a la procedencia de los inmigrantes. Al contrario, se promueve la igualdad entre ellos, y la sensación de comunidad que se vive en estos barrios donde conviven e interactúan distintas colonias de migrantes. La historia que subyace es una historia de unidad, de convivencia y de aceptación entre las distintas culturas que, como si permanecieran aislados en su propio mundo, viven en un barrio de Manhattan en el que el idioma que predomina en las calles es el español. En esta obra, podríamos decir que se muestra una cara más amable de la situación de los inmigrantes, si bien es cierto que no debemos caer en el error de pensar que este musical desacredita al anterior. Nos encontramos ante dos visiones diametralmente opuestas, y esto tiene que ver con la diferencia ente sus autores, su intención desde el origen de la producción y la época en la que ambos musicales fueron escritos.

Puertorriqueños, polacos o dominicanos, la realidad es que muy pocas son las creaciones de Broadway que muestran la realidad de la inmigración en una ciudad tan global como lo es Nueva York. De la misma manera que, a pesar de que los inmigrantes conforman una gran parte de la población estadounidense, aún hoy en día es difícil encontrar actores hispanos o latinos en grandes superproducciones musicales, que cuenten sus propias historias. Sin embargo, parece que, tras décadas evitando confrontar al espectador con una realidad que es más fácil ocultar, las comunidades de creadores latinos están decididas a dejar huella en el desarrollo del musical estadounidense. Poniendo de manifiesto las dificultades a las que se enfrentan, rompiendo estereotipos y generando nuevos discursos que exploren la realidad de comunidades que han permanecido relegadas a un segundo plano. 


\section{BIBLIOGRAFÍA}

Barrueto, J. (2014). The Hispanic Image in Hollywood, a postcolonial aproach. Nueva York: Peter Lang.

Gradenwitz, P. (1987). Leonard Bernstein, The infinite Variaty of a Musician. Nueva York: Berg Publishers Limited.

LaFAVE, K. (2015). Experiencing Leonard Bernstein: a listener's companion. Maryland: Rowman \& Littlefield Publishers.

Lev, P. (2003). The Fifties, transforming the screen 1950-1959. Los Ángeles: University of California Press.

Maldonado-Denis, M. (1977). Puerto Rico y Estados Unidos: emigración y colonialismo. México: Siglo Veintiuno Editores.

Maldonado-Denis, M. (1977). Puerto Rico, una itnerpretación histórico-social. México: Siglo Veintiuno Editores.

Percy Kraly, E. y Miyares, Ines (2001). «Inmigration to New York, Policy, Population and Patterns», en N. Foner, New Inmigrantes in New York (pp. 33-80). Nueva York: Columnia University Press.

Reynoso, J. (2003). Dominican Immigrants and Social Capital in New York City: A Case Study. Encrucijada/Crossroads 1.1, 57-78.

Ricourt, M. (2016). Dominicans in New York, Power from the margins. Nueva York: Routledge.

Stavans, I. (1995). The Hispanic Condition, Reflections on Culture and Identity in America. Nueva York: Harper Perennial.

Wolf, S. (2011). Changed for Good: A Feminist History of the Broadway Musical. Oxford: Oxford University Press.

Filmografía

In the Heights (Jon M. Chu, 2021).

West Side Story (Jerome Robbins y Robert Wise,1961).

\section{IMÁGENES}

Imagen 1. Friedman-Abeles (1957) Stephen Sondheim, Arthur Laurents, Harold Prince, Robert E. Griffith, Leonard Bernstein, and Jerome Lawrence in rehearsal for the stage production West Side Story. [Fotografía]. Recuperado de https://digitalcollections.nypl.org/.

Imagen 2. Recuperado de copia DVD.

Imagen 3. Recuperado de copia DVD.

Imagen 4. Recuperado de copia DVD.

Imagen 5. Recuperado de https://www.playbill.com/.

Imagen 6. Recuperado de https://www.playbill.com/.

Imagen 7. Recuperado de https://www.playbill.com/. 


\title{
EL ESPEJO DEFORMANTE. HERACLES EN EL CINE DEL SIGLO XXI
}

\author{
Joana Rodríguez Pérez \\ Universidad de La Laguna
}

\section{RESUMEN}

Este artículo analiza la manera en la que el cine del siglo Xxi acoge a una de las figuras más importantes de la mitología clásica, el héroe griego Heracles. De qué forma el arte cinematográfico ha captado y adaptado los hechos que las fuentes clásicas cuentan del mito del hijo de Zeus. Y más allá de su historia, de qué modo ha asumido, variado o descontextualizado la personalidad, los valores y la actitud de un ser muy de su tiempo. De esta manera, comparando la historia escrita con la historia rodada, examinamos qué episodios de la vida del héroe se han llevado a la gran pantalla, cuáles no y tratamos de explicar el porqué de ello. Esta comparativa, además, nos valdrá para determinar las interrelaciones que se producen entre la producción de los films y la obra literaria en la que estos se basan.

Palabras Clave: Heracles, cine, péplum, mitología, siglo Xxi, adaptación.

THE DISTORTING MIRROR.

HERACLES IN $21^{\text {ST }}$ CENTURY CINEMA

\section{Abstract}

This article examines how $21^{\text {st }}$-century cinema has embraced one of the most important figures in classical mythology, the Greek hero Herakles. How cinematic art has captured and adapted the events that classical sources tell of the myth of the son of Zeus. And beyond his story, how it has assumed, varied or decontextualized the personality, values and attitude of a being that was undeniably of his time. In this way, by comparing the written story with the filmed story, we examine which episodes of the hero's life have been brought to the big screen and which of them have not, and try to explain why. This comparison will also help us to determine the interrelations between the production of the films and the literary work on which they are based.

KeYwORDs: Heracles, cinema, peplum, mythology, $21^{\text {st }}$ century, film adaption. 


\section{LOS TEXTOS CLÁSICOS Y EL CINE}

En los primeros años del cine, los pioneros en este arte se valían de escenas costumbristas y prácticamente anecdóticas que llegaran más fácilmente a un público que estaba comenzando a asimilar un nuevo lenguaje. Además, la sencillez de los argumentos les permitía centrarse en la investigación, la innovación y el descubrimiento de las nuevas posibilidades de las que disponían y hasta dónde les permitía llegar el uso de la cámara. Con el paso del tiempo, fueron dándose cuenta de la capacidad narrativa que tiene el cine y a partir de entonces surge una fuerte relación entre este y la literatura que se mantiene vigente hasta hoy en día. La principal razón que tuvieron los cineastas para recurrir a la literatura fue el caudal de ideas y argumentos que esta proporcionaba, unida a que la mayor parte del público que acudía al cine ya conocía las obras y a sus autores, permitiendo así una mayor difusión y una mejor comprensión de los films a pesar de la ausencia de sonido en las primeras décadas.

La relación de las diferentes vertientes literarias con el nuevo arte ha sido siempre compleja y muy variada, y ha tenido un peso muy importante a lo largo de toda la historia del cine. Su reiterada utilización no disminuye la dificultad que comporta realizar una adaptación literaria pues, generalmente, la historia escrita ya tiene una importancia considerable por sí misma, y su lector, que antes daba, en cierto modo, rienda suelta a su imaginación, ahora recibe toda la información a través de las imágenes del film. A pesar de este riesgo, de lo que no cabe duda es de que "cuando se captan íntegramente representaciones teatrales extraordinarias, cuidadísimas en todos sus aspectos, de obras clásicas o de óperas, el cine asume un contenido cultural, de difusión muy eficaz» (Gómez Mesa, 1978).

En este sentido, dentro del gran abanico de fuentes que han servido a la inspiración cinematográfica, las obras de la literatura clásica griega-Homero, Eurípides, Apolodoro, etc.- han sido, desde el surgimiento del séptimo arte, uno de los temas más recurrentes para los cineastas. Y es que, ya desde la Antigüedad, la mitología ha sido una de las mayores productoras de espectaculares historias y hazañas que han inspirado a artistas de todos los tiempos. De este modo, con el paso de los años y la eclosión de nuevos métodos y lenguajes, la mitología continuará siendo una de las grandes inspiradoras para la producción artística incluyendo el campo cinematográfico. Así, desde fechas muy próximas a su aparición, los textos clásicos serán representados en la gran pantalla. Ya en 1898 -tres años después de la aparición oficial del cine- Georges Méliès rodaba Pygmalion et Galathée y un año más tarde, en 1899, Neptune et Amphitrite. Varios fueron los films que el francés dedicó a los temas mitológicos, pero no fue el único, se rodaron Venus et Adonis (1901), de Alice Guy; La naissance de Venus (1902), de Ferdinand Zecca; La caduta di Troia (1911), de Giovanni Pastrone; The Triumph of Venus (1918), de Edwin Bower Hesser; Helena (1924), de Manfred Noa; Night Life of the Gods (1935), de Lowell Sherman; o Mourning Becomes Electra (1947), de Dudley Nichols.

Siendo estos solo algunos de los títulos, ya que durante las primeras décadas del siglo $\mathrm{xx}$ fueron numerosas las producciones que partían de estos textos con, aproximadamente, tres mil años de antigüedad: 
A lo largo de las décadas de los 10, 20, 30 y 40 se continuó con la producción de films que trataban temas en esta misma línea, muchos basados en novelas históricas, aunque con algunas notables creaciones de origen mitológico, hasta llegar a la eclosión de los ańos 50, con algunas de las más importantes películas sobre la épica homérica, como las exitosas Ulises (Mario Camerini, 1954) o Helena de Troya (Robert Wise, 1955), y que propiciaron la aparición de un fenómeno de importancia en el ámbito cinematográfico, el péplum (Ramírez, 2017).

Es entonces, en los años 50, cuando estas películas cobran mayor importancia y dan lugar a la aparición de un género en sí mismo. Hay que tener en cuenta que el péplum, a lo largo de su desarrollo, se ha convertido en un género muy amplio y complejo que no se puede definir con unas características concretas y encorsetadas. Por tanto, dentro de este género, tal y como expone Antonio Gonzalès (1990), se pueden diferenciar cinco categorías diferentes:

- Le péplum à caractère mythologique comprenant les films sur Hercule et ses dérivés cinématographiques tels que Maciste, Ursus et les adaptations d'autres mythes tels que ceux d'CEdipe, d'Achille, etc. [...]

- Le péplum fantastique où l'on retrouve le film de S. Leone Le Colosse de Rhodes (1960) mais également des films alliant sans scrupules les différentes périodes historiques comme dans Toto contre Maciste (F. Cerchio, 1961) [...].

- Le péplum religieux qui est constitué de différents sous-groupes allant des adaptations bibliques telles que Les Dix Commandements de C.B. De Mille (1956) au martyre des chrétiens [...]. Il va sans dire que ce film spiritualiste nous semble appartenir au péplum par ses caractères chronologiques et par la thématique qui y est développée.

- Le péplum catastrophe a attiré lui aussi bon nombre de producteurs et de réalisateurs. Si l'intérêt fut grand, il se porta quasi exclusivement sur l'époque romaine qui offrait à la vision traditionnelle attachée à la Rome impériale des exemples symboliques [...].

- Le péplum militaire : certains lecteurs objecteront que le péplum possède comme une des caractéristiques fondamentales celle d'être un lieu où l'action se noue et se dénoue bien souvent autour d'une bataille ou d'un combat individuel de type héroïque ${ }^{1}$.

${ }^{1}$-El péplum de carácter mitológico incluye películas sobre Hércules y sus derivados cinematográficos como Maciste, Ursus y adaptaciones de otros mitos como los de Edipo, Aquiles, etc. [...]. - El péplum fantástico lo encontramos en la película de S. Leone El Coloso de Rodas (1960) pero también en películas que combinan sin escrúpulos los diferentes periodos históricos como Toto contra Maciste (F. Cerchio, 1961) [...]. -El péplum religioso se compone de diferentes subgrupos que van desde adaptaciones bíblicas como Los diez mandamientos (1956) de C.B. De Mille hasta el martirio de los cristianos [...]. Ni que decir tiene que estas películas espiritualistas parecen pertenecer al péplum por sus características cronológicas y no por el tema que en ellas se desarrolla. -El péplum de tragedia también atrajo a varios productores y directores. Si el interés era grande, este se centraba casi exclusivamente en la época romana, que ofrecía ejemplos simbólicos de la visión tradicional ligada a la Roma imperial [...]. -El péplum militar: algunos lectores objetarán que el péplum tiene como 
Así, dentro del péplum mitológico, además de las ya mencionadas por Ramírez Guedes, fueron producto de este periodo cumbre -décadas de los 50 y principios de los 60- films como L'amante di Paride (1954), de Marc Allégret, o La legenda di Enea (1962), de Giorgio Rivalta. Esta tendencia, aunque pierde fuerza después de estas fechas, no desaparece por completo, continuando su desarrollo a lo largo de la historia del cine y llevándonos hasta producciones realmente actuales ejecutadas ya en nuestro siglo. Así, en el siglo XXI, las producciones del péplum se distribuyen casi igualitariamente por los diferentes subgéneros. Sin embargo, el cambio es notorio dentro del péplum mitológico, que a diferencia de las producciones de los años 50 -que eran diversas y tomaban como inspiración muchas y variadas historias mitológicas- ahora habrá una tendencia clara hacia las historias de los principales héroes de los textos clásicos y sus sobrehumanas anécdotas. De esta manera la mayor parte de las producciones de péplum mitológico de los años 2000 tendrán como protagonistas, como ya se dijo, a dos de los héroes más conocidos de la mitología, ambos hijos de Zeus, Hércules y Perseo.

\section{HERACLES EN LA MITOLOGÍA GRECORROMANA}

La mitología está constituida principalmente por un conjunto de historias y leyendas relacionadas con la religión griega. Esta, en la actualidad, es entendida de manera general como el medio por el cual los antiguos griegos daban explicación a los sucesos de la naturaleza y a los diferentes acontecimientos que tenían lugar durante el desarrollo de su civilización. Era, en definitiva, parte de su conocimiento del mundo y el soporte cultural de su civilización.

Dentro de los cuantiosos textos que esta inspiró, son muchos los que recogen la historia de uno de los más importantes héroes de la mitología clásica griega, Heracles. La leyenda de este semidiós es una de las más extensas y complejas de los textos mitológicos, presentando diversas historias cumbres que se entrecruzan con otros muchos personajes y generan así distintas tramas dentro de una misma.

Heracles es hijo de Zeus y Alcmena, mortal de la que el dios se encaprichó y, tomando la forma de su esposo, el rey Anfitrión, yació con ella. A la vuelta del mortal, este se reconcilió con su esposa y engendraría a un segundo niño hermano gemelo de Heracles, Ificles. Celosa Hera de Alcmena y conocedora de que Heracles reinaría en Argos si naciera antes que su primo Euristeo, mandó a su hija Ilitía, diosa de los nacimientos, a retrasar el parto de Heracles e Ificles y a adelantar, por el contrario, el de Euristeo, quien heredaría finalmente el trono. Empujada por su inquina hacia Heracles, cuando era aún muy pequeño, Hera mandó dos grandes serpientes a su alcoba cuando este y su hermano descansaban en la cuna. Mientras

una de sus características fundamentales la de producirse en un lugar donde la acción se resuelve a menudo a través de una batalla o un combate heroico individual. Traducción de la autora. 
el pequeño Ificles rompió en llanto, su hermano cogió a los reptiles por el cuello -uno en cada mano- y los ahogó.

Ya en la etapa adulta, Hera continuó actuando en contra de Heracles y queriendo que se pusiera al servicio de su primo Euristeo mandó sobre él un arrebato de locura que le llevó a matar a su mujer, Mégara, y a sus hijos. Sintiendo la necesidad de expiar sus pecados, Heracles se postró ante Euristeo y aceptó realizar los doce trabajos que este le mandaría. Estas doce hazañas han sido las principales historias por las que se conoce a Heracles como uno de los más importantes héroes griegos, y que, por este orden, suponen:

1. Matar al león de Nemea y despojarle de su piel.

2. Matar a la hidra de Lerna.

3. Capturar a la cierva de Cerinea.

4. Capturar al jabalí de Erimanto.

5. Limpiar los establos de Augías.

6. Matar a las Aves del lago Estínfalo.

7. Capturar al toro de Creta.

8. Robar las yeguas de Diomedes.

9. Robar el cinturón de Hipólita.

10. Robar el ganado de Gerión.

11. Robar las manzanas doradas del jardín de las Hespérides.

12. Capturar al can Cerbero y sacarlo de los infiernos.

Además de estos, Heracles vivió otras hazañas independientes, paralelas o no a los doce trabajos, que también han fraguado su popularidad. Algunos ejemplos de ellas son:

- El enfrentamiento con Anteo: Anteo era hijo de Gea, la madre Tierra, y Posidón y vivía en Libia. Allí, hacía que cualquier extranjero que pasara por su tierra se enfrentara con él y una vez que le daba muerte, decoraba el templo consagrado a su padre con sus restos. Cuando Heracles iba en busca de las manzanas de oro (según Apolodoro, Biblioteca II, 11,23) o de las vacas de Gerión (según Diodoro Sículo, Biblioteca histórica Iv, 17, 4) pasó por la localidad y tuvo que enfrentarse al gigante, así, levantándolo de la tierra -de donde tomaba su fuerza-, Heracles le dio muerte.

[...] Heracles arribó a Libia. Lo primero que hizo fue retar a un combate a Anteo, de notoria fama por su fuerza física, su experiencia en la palestra y por dar muerte a todos los extranjeros que había vencido en la lucha; Heracles trabó combate con él y lo mató (Diodoro de Sicilia Iv, 17, 4).

Una vez informado atravesó Libia. Reinaba allí Anteo, hijo de Posidón, que daba muerte a los extranjeros obligándolos a luchar. Forzado a pelear con él, Heracles lo mató con su brazo mientras lo mantenía en vilo, pues si tocaba la tierra se vigorizaba, y por ello algunos dijeron que era hijo de Gea (Apolodoro II, 11, 23). 
- El enfrenamiento con Caco. Este episodio pertenece puramente a fuentes romanas como la Eneida de Virgilio (viII, 190-433) o Tito Livio (Historia de Roma desde su fundación, I, 1,7). Según estas, cuando Heracles regresó tras robar el ganado de Gerión, Caco hurtó al héroe algunos de los ejemplares que pastaban libres. Astuto, para no ser pillado por Heracles tiró de la cola de los animales para que estos caminaran hacia detrás y las huellas parecieran ir al sentido contrario al que realmente iban. Cuando Heracles finalmente se dio cuenta y lo descubrió lo mató con su maza. Además de las fuentes ya mencionadas, Ovidio recoge también el episodio en Fastos (I, 543-578):

... Era por la mańana; al despertar del sueńo, el Tirintio, que condujo el ganado, notó que le faltaban de la cuenta dos toros. [...] El feroz Caco los había arrastrado por el rabo a una cueva [...] Caco [...] de fuerzas proporcionadas a su talla, y su talla era enorme. Mulcíber ${ }^{2}$ era el padre de este fenómeno [...] el hijo de Júpiter se marchaba dando por perdida parte de sus bueyes; los animales robados mugieron con ronco bramido. «He oído el reclamo», dijo, y siguiendo el bramido llegó el vengador a la impía caverna [...] Caco emprendió el primer ataque a brazo partido, dirimiendo la cuestión salvajemente con piedras y estacas. Al no conseguir nada por estos medios, el muy cobarde acudió a las mañas de su padre, vomitando llamas por la boca que retumbaba [...] Consigue echarle mano el Alcida y sujetando la maza de tres nudos se la estampa al bandido tres o cuatro veces en plena cara. Este cae, vomitando humo mezclado con sangre, y al morir, golpea la tierra con su ancho pecho.

- Muerte de Licas. Licas fue el compañero de Heracles hasta su muerte. Tras servirle en la guerra contra Ecalia y vencer, el héroe heleno le mandó pedirle a Deyanira un atuendo apropiado para hacer el sacrificio a Zeus. La ninfa le entregó una túnica impregnada con la sangre envenenada de Neso que provocó en la piel de Heracles terribles heridas. Debido a su agonía en un acto desesperado el semidiós culpó a su compañero de lo ocurrido y agarrándolo por un pie lo lanzó al espacio. Según formula Apolodoro (II, 7, 7):

Con el fin de celebrar sacrificios envió al mensajero Licas a Traquis en busca de un hermoso vestido. Por él Deyanira supo de Yole y temerosa de que Heracles la prefiriese, creyendo que la sangre vertida por Neso era realmente un filtro amoroso, untó con él la túnica. Vestido con ella, Heracles se disponía a ofrecer el sacrificio, cuando, por calentarse la túnica, el veneno de la Hidra empezó a descomponer la piel; Heracles, cogiendo a Licas de los pies, lo despeñó y al intentar arrancarse la túnica, fuertemente adherida a su cuerpo, se desollaba.

2 Mulcíber es uno de los epítetos que se le atribuyen al dios romano Vulcano (equivalente de Hefestos en la mitología griega). 


\section{HERACLES COMO HÉROE CINEMATOGRÁFICO}

El cineasta italiano Giovanni Pastrone produjo en 1914 Cabiria, una película ambientada en la antigüedad e inspirada en las fuentes mitológicas, que contaba como protagonista con un personaje llamado Maciste, el cual originalmente respondía al nombre de Hércules ${ }^{3}$. Bajo estas características, este film puede considerarse el primero que trabaja en relación con la figura del héroe griego, aunque no sea de forma directa. A partir de esta cinta, el personaje de Maciste se convirtió en un protagonista frecuente en los films recreados en la antigüedad y, de algún modo, se le entendió como un sustitutivo -o un sinónimo- del verdadero Hércules. De este modo, en 1915, volvería a la pantalla con Maciste, de Giovanni Pastrone y Vincenzo Denizot (Giordano, 1998).

Sin embargo, aunque estos films pueden entenderse como el inicio de la «carrera cinematográfica» del héroe, su debut tuvo lugar en 1958 con el film de Pietro Francisci Le fatiche di Ercole (Hércules), protagonizada por Steve Reeves, y su secuela al año siguiente, Ercole e la regina di Lidia (Hércules y la Reina de Lidia).

Con el auge del péplum italiano serán cuantiosos los films que, a pesar de no contar con absoluto rigor histórico, retroceden al tiempo de las antiguas Grecia y Roma. Además, cientos de ellas, producidas a lo largo de todo el siglo xx, tendrán como protagonista al hijo de Zeus y Alcmena pero no por ello se desarrollan exclusivamente en el tiempo que se supone que el héroe vivió. De este modo, Hercules in New York (Hércules en Nueva York), de 1969, protagonizada por Arnold Schwarzenegger ${ }^{4}$, es ejemplo del impulso que tuvo la figura del héroe mitológico en el cine y cómo este la usó sin el más mínimo escrúpulo. En 1997, incluso Disney estrena una versión de animación del personaje absolutamente descontextualizado donde se nos presenta a un Hércules Olímpico enfrentado a Hades.

Desde entonces, Heracles desapareció de las pantallas y no regresó a ella hasta siete años más tarde, en el 2005, con Hercules, de Roger Young. Sin embargo, aunque este fue el primer contacto cinematográfico del último milenio, su figura reaparecería con mucha más fuerza en el 2014. Así, en este año se estrenaron tres películas que llevan en el título el nombre del héroe: Hercules Reborn, The legend of Hercules y Hercules. Estas últimas cuatro producciones, que tienen lugar en este siglo, son por tanto, el objeto de nuestro estudio.

${ }_{3}^{3}$ Macistius, en su forma latina, también era un epíteto de Heracles mencionado por Estrabón: «A medio camino del templo de Heracles Macistio y el río Acidón» (Estrabón viII, 3, 21).

${ }^{4}$ Arnold DStrong en los títulos de crédito. 

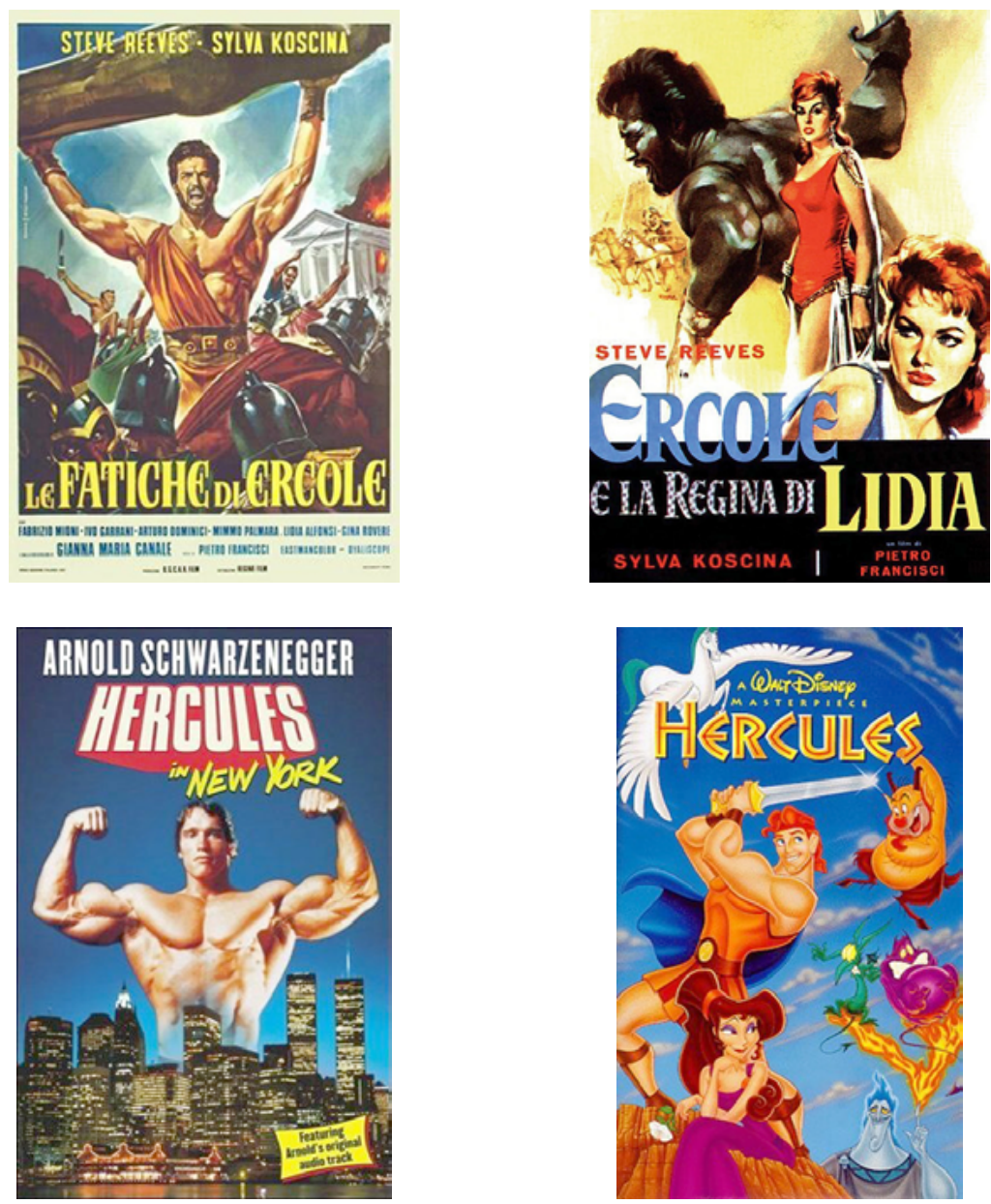

\section{HERCULES (2005), ROGER YOUNG}

Este film, producido a partir de una miniserie de televisión, se abre al espectador con la escena de un festejo consagrado a la diosa Hera en el que sus devotas hacen un sacrificio en su honor. En esta ocasión las mujeres descubren que su ofrenda es un hermafrodita y que por pertenecer mitad de su ser al mundo femenino, no pueden matarlo. Es por ello que Alcmena -la sacerdotisa- le hiere en los ojos dejándole ciego.

Esa misma noche, Alcmena yace con un hombre al que no se le ve el rostro pero muestra en el brazo una cicatriz en forma de rayo que parece hacer alusión a Zeus, ya que el rayo es su atributo. Sin embargo, vista esta escena por Linus, esta marca hará que más tarde el misterioso personaje sea identificado por este de manera que, al final del film, se nos desvela que realmente el hombre que fuerza a 
Alcmena no era Zeus sino Anteo ${ }^{5}$, lo cual supone una importante deformación del mito de Heracles.

$\mathrm{Al}$ amanecer, Tiresias ${ }^{6}$, vidente al que Alcmena había dejado ciego la noche anterior, comparece ante el matrimonio y advierte que la mujer está embarazada de dos hijos y uno de ellos no es de Anfitrión. La obsesión que presentan los personajes de esta película por la rivalidad entre Hera y Zeus hace que Alcmena rechace por completo al que cree hijo de Zeus y quiera incluso deshacerse de él incrementando su odio cuando Tiresias advierte que «el siguiente hijo nacido de la casa de Perseo ascenderá al trono de Tirinto y regirá todas las tierras que tú riges ahora». Finalmente, Alcmena alumbra a sus dos hijos (fig. 1), pero antes había llegado al mundo el hijo varón de Esténelo ${ }^{7}$-tío de Alcmena y rey de Tirinto-, Euristeo, quien heredará el trono.

Esta escena de la concepción y alumbramiento del héroe y su hermano está recogida por varios mitógrafos. Apolodoro en Biblioteca (II, 4, 8) menciona el episodio contando que antes de que Anfitrión llegara a Tebas, Zeus se transformó en él y yació con Alcmena una noche que hizo durar 24 horas. Cuando el rey llegó y vio que Alcmena le recibía con desgana le preguntó por qué lo hacía y esta respondió que ya había estado con él la noche anterior, más tarde Tiresias aclaró a Anfitrión que la unión amorosa había sido con Zeus. Finalmente Alcmena concibió dos hijos, uno de Zeus (Heracles) y otro de Anfitrión (Ificles). Por su parte, Higino, en las Fabulas (xxix), lo expone prácticamente de la misma forma, pero obviando la existencia de un segundo hijo engendrado por Anfitrión.

La mayor de las distorsiones que comete el film en este episodio es sin duda la aparición de la figura de Anteo, que además de no tener lugar en el mito, no se encuentra justificación posible para adjudicarle en el film la paternidad de Hércu-

5 A pesar de que en esta película toma un lugar que en los textos no corresponde, cabe aclarar que Anteo, como ya vimos más arriba, fue un personaje mitológico hijo de la madre Tierra y que, como en el film, ganaba su fuerza de ella. Además, también es cierto que luchó contra Heracles y este lo mató. Sin embargo, a diferencia de la película, el hecho ocurrió mientras Heracles pasaba por Libia de camino a buscar las manzanas de oro y lo mató ahogado entre sus brazos. Así lo cuenta Apolodoro (II, 5, 11).

${ }^{6}$ Tiresias en la mitología es un célebre adivino. Hay varias versiones de cómo consiguió su don. Apolodoro (III, 6, 7) lo expone de la siguiente forma «... Unos dicen que lo cegaron los dioses por haber revelado a los hombres sus secretos; pero según Ferecides lo cegó Atenea, pues [...] él vio a la diosa completamente desnuda y esta, tapándole los ojos con sus manos, lo cegó...». Por su parte Hesíodo en Fragmentos apunta que Tiresias «había hallado unas serpientes copulando cerca de Cilene y, por haberlas herido, fue transformado de hombre en mujer; pero al ver aquellas serpientes uniéndose en otra ocasión, se volvió hombre de nuevo, por eso cuando Zeus y Hera disputaban sobre quién disfrutaba más en el amor [...] preguntaron a Tiresias. Este dijo que, si el placer tuviera diez partes, los hombres gozarían sólo de una y las mujeres de nueve; entonces Hera lo cegó, pero Zeus le concedió el arte de la adivinación». Con esto también se explica el porqué de que en el film lo presentaran como un hermafrodita (Melampodia, 275).

7 Según las fuentes (Apolodoro II, 4, 5), Esténelo es hijo de Perseo y Andrómeda y padre, junto con Nicipe, de Euristeo. Además, tío de Alcmena. De esta manera el personaje coincide perfectamente en el film y en las fuentes clásicas. 
les y que posteriormente Alcmena obvie este hecho culpando a Zeus de una actitud lujuriosa.

De nuevo en el film, cegada de rabia y con el objetivo de deshacerse del hijo de Zeus, Alcmena acude a las "Favoritas de Hera», dos harpías ${ }^{8}$ que, para identificar cuál de los dos niños es hijo del dios, hacen que los pequeños mamen de su pecho alegando que solo un verdadero hijo engendrado por Zeus podría alimentarse de ella. Sin embargo, el pequeño que se amamanta primero (fig. 2), no solo coge el pecho, sino que se aferra con ganas a él y lo muerde sin soltarlo'. De esta manera, las harpías identifican al hijo de Zeus y le dan el nombre de Hércules - Heracles significa la "gloria de Hera»- mientras que, por su parte, Alcmena llama a su otro hijo Ificles.

Tras la visita a las harpías, afanada por matar a Hércules, Alcmena pide a Anfitrión que se deshaga del niño, pero como este se niega a hacerlo, la mujer coloca dos serpientes en la cuna del Hércules aún bebé (fig. 3), pero el pequeño, en lugar de asustarse, las agarra con las manos y las mata (fig. 4).

En los textos clásicos, este suceso tiene diferentes versiones. Primero se debe aclarar que las harpías no tienen nada que ver con la leyenda de Heracles. Además de esto, el nombre del héroe fue acuñado, según Apolodoro (II, 4, 12), por la Pitia ${ }^{10}$ cuando ya este entraba en la edad adulta. Del mismo modo, es erróneo atribuir a estos seres el amamantamiento del muchacho ya que en los textos quien le amamanta es la propia Hera. Sin embargo, es lógico que en el film se les atribuya a ellas ya que a pesar de que los dioses son nombrados constantemente, nunca se les muestra, de modo que Hera no podría aparecer. Es también responsabilidad de la diosa el suceso de las serpientes, pues tal y como Píndaro (Nemea I, 35) expone estando Heracles recién nacido Hera envió unas serpientes que penetraron en la habitación para acabar con los niños. Pero Heracles las sujetó con sus dos manos por sus cuellos durante tanto tiempo que las dejó sin aliento. Sin embargo, según cuenta Apolodoro en Biblioteca II, 4, 8, otros mitógrafos como Ferecides afirman que fue el propio Anfitrión quien expondría a los pequeños ante los reptiles para saber cuál de ellos era el hijo de Zeus y cuál suyo. Teniendo en cuenta que el personaje de Alcmena representa a una sacerdotisa de Hera -siendo en cierto sentido representación de ella- y que desde el primer momento muestra una actitud de rechazo hacia su propio hijo, es completamente lógico dentro del guion y de la trama que sea ella

${ }^{8}$ Las harpías son seres alados que pertenecen a la generación preolímpica, hijas de Electra y Taumante. Suelen ser dos: Aelo (también Nicótoe) y Acípete, aunque se conoce también una tercera: Celeno. Su iconografía responde a mujeres aladas o aves con cabeza de mujer y afiladas garras. Son raptoras de niños y de almas.

9 Esta escena de la película se puede relacionar con la leyenda del surgimiento de la Vía Láctea, ya que no deja de ser una variación de este suceso. Según las fuentes, cuando Heracles era aún un niño se amamantó del seno de Hera para conseguir la inmortalidad. Se cuenta que fue Hermes quien le acercó al pecho de la diosa mientras esta dormía, y que cuando se despertó lo apartó de ella bruscamente. Así, la leche que se derramó dejó una marca en el cielo: la Vía Láctea.

${ }^{10}$ La Pitia era la sacerdotisa mayor del templo de Apolo en Delfos y la que daba respuestas a las consultas del oráculo. Su nombre viene de «Pito», que es el nombre original del lugar donde se emplazó el santuario. 


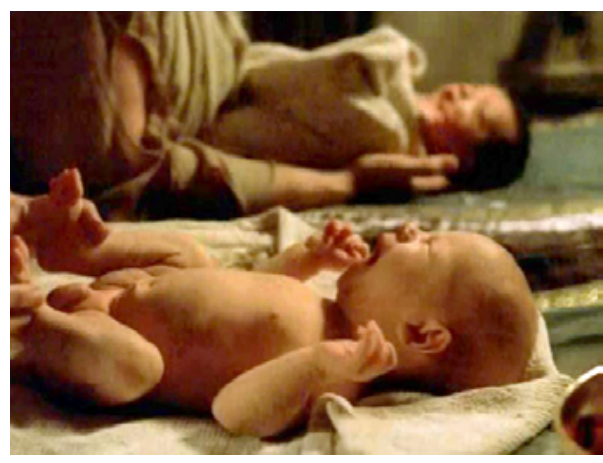

Fig. 1. Hércules e Ificles recién nacidos.

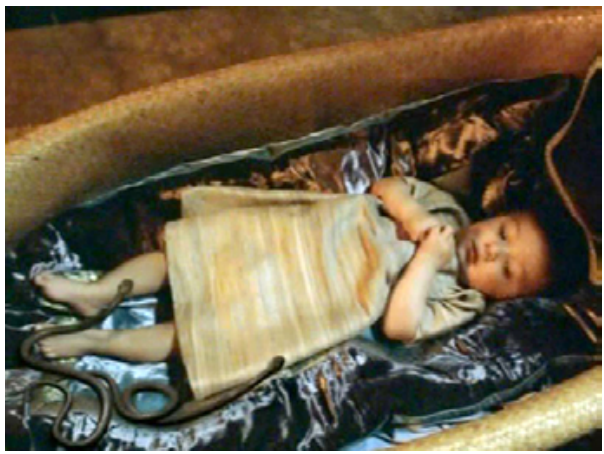

Fig. 3. Las serpientes que Alcmena deposita en la cuna amenazan al pequeño Hércules.

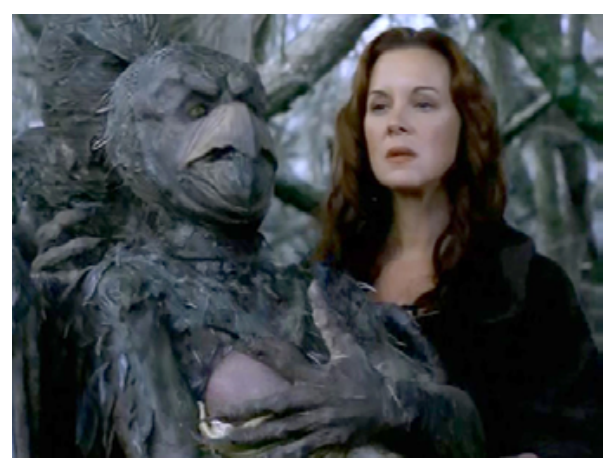

Fig. 2. Hércules amamantándose de la harpía mientras Alcmena espera para saber cuál de sus hijos es de Zeus.

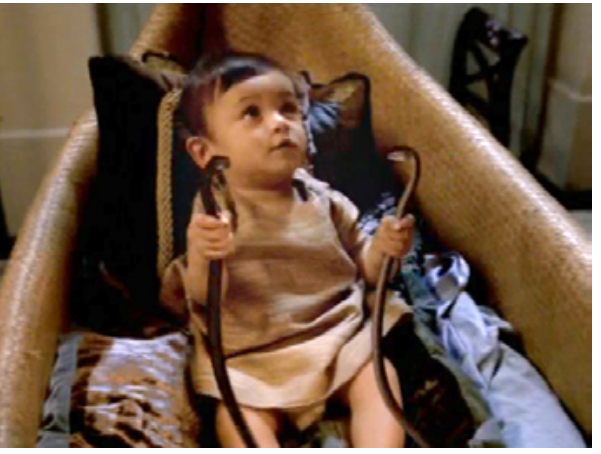

Fig. 4. Hércules ahoga a los dos reptiles.

quien intente matar a Hércules con las serpientes y no Hera, que como decíamos nunca aparece de forma física, o Anfitrión, que ha sido de algún modo su protector. En esta producción de 2005, la formación del joven Hércules es simultánea con la de su hermano Ificles y está bajo la responsabilidad del centauro Quirón ${ }^{11}$, quien los instruye en el arte de manejar la espada, y Linus quien los ilustra en el arte de la música. Hércules, si destacaba en las lecciones del centauro, no gozaba

${ }^{11}$ Según la mitología, Quirón es el más célebre y sabio de los centauros. Además de a Heracles, también educó a Aquiles, Jasón, Asclepio y, según algunos, hasta al propio Apolo. Sus lecciones incluyen la música, el arte de la guerra, la caza, la medicina y la moral. 


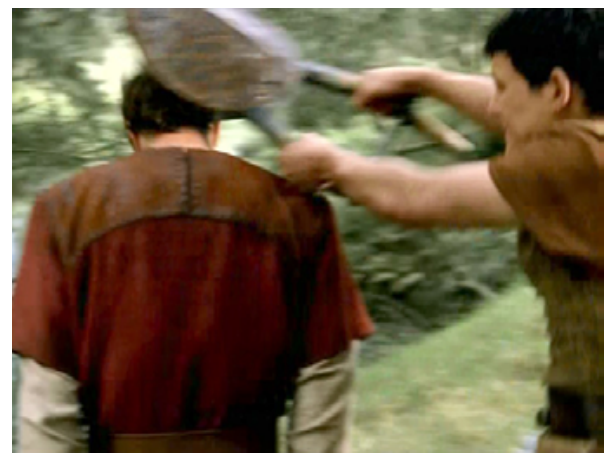

Fig. 5. Hércules golpeando a Linus con la lira. Hércules (2005), Roger Young.

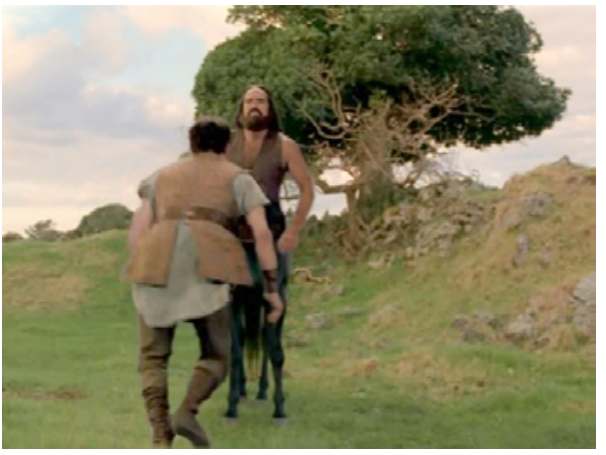

Fig. 7. Quirón y Hércules en las montañas. Hércules (2005), Roger Young.

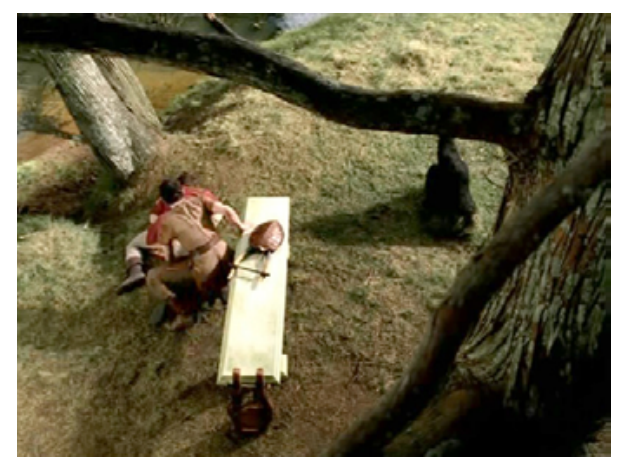

Fig. 6. Linus desfallecido tras recibir un golpe en la cabeza por parte de Hércules. Hércules (2005), Roger Young.

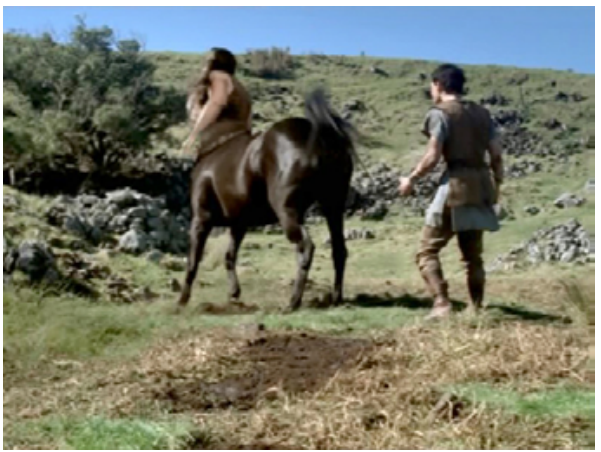

Fig. 8. Quirón y Hércules en las montañas. Hércules (2005), Roger Young.

de la misma suerte en la música, así que irritado por las reprimendas y golpes que el maestro le daba alzó el instrumento que estaba tocando y golpeó al músico en la cabeza dejándole inconsciente en el suelo (figs. 5 y 6). Creyendo que Hércules había causado la muerte de Linus -en realidad será salvado por la ninfa Deyanira-, el rechazo hacia el muchacho en la ciudad de Tebas fue en aumento y el rey Creón ${ }^{12}$ -padre de Mégara, muchacha por la que Hércules mostraba interés- le perdona la vida, pero con la condición de que abandone la ciudad yéndose a las montańas a cuidar del ganado de su padre. De esta manera, el joven se marcha con Quirón, quien le formará y cuidará lejos de su familia (figs. 7 y 8 ).

12 En la mitología su nombre es Creonte y ciertamente fue rey de Tebas y padre de Mégara. 
Sin embargo, la formación y juventud del héroe tebano cuentan los textos que corrió a cargo de diferentes personas. Apolodoro (II, 4, 9) nos dice que Heracles fue instruido por Anfitrión a manejar el carro, por Autólico a luchar, por Éurito a disparar el arco, por Cástor a usar las armas y por Lino a tocar la cítara. Este último será el personaje al que el film es fiel, a excepción de modificar su nombre por una versión latina -Lino equivale a Linus- y de «resucitarlo» convirtiéndolo más tarde en el fiel amigo de Hércules. En este aspecto las fuentes son rotundas y describen el asesinato del músico por parte de Hércules con un golpe en la cabeza con una lira o una cítara, pero a diferencia de la película, en la mitología fue el propio Anfitrión quien, por miedo a que cometiera otro delito, envió al joven fuera de la ciudad a cuidar el rebaño, donde llegó a la adultez consiguiendo gran altura y fuerza. De lo que no hay constancia en el mito es de la presencia del centauro Quirón.

De esta primera parte del film, en la que se presenta la concepción, el nacimiento y la juventud del héroe, se puede decir que, aunque es evidente que añade modificaciones con respecto a los textos, se muestra de forma bastante fiel la realidad del inicio de vida de Heracles. Así, la película permite que el espectador -aun pudiendo ser ignorante de los mitos- recree en su mente una idea bastante próxima a las fuentes clásicas. Esta producción, ya sea por su minutaje o por su interés en aproximarse a los textos originales a diferencia de la mayoría de las películas que tratan la vida del héroe griego, es la que mejor expone esta etapa de su vida. De manera general, los films se centran en la vida gloriosa de Hércules y, además de su enfrentamiento con las serpientes, que es considerada su primera gran hazaña, no suelen detenerse en otros hechos de su infancia. Por el contrario, la película de Young hace un recorrido bastante próximo a su juventud acercándonos incluso a qué tipo de formación recibió el héroe.

A pesar de que esta producción le preste especial interés al crecimiento del joven Hércules, la película dedica el mayor grosor a los episodios más conocidos y populares de las hazañas del hijo de Zeus: sus doce trabajos. Muchos conocerán cuáles son estos, pero ¿y el motivo que le llevó a hacerlos? En el film Hércules, de Roger Young, el aún adolescente Hércules se escapó una noche a un festival en honor a Hera en el que se encontraba su idolatrada Mégara. Dejándose llevar por la pasión pasaron la noche juntos y la muchacha se quedó embarazada de trillizos. Acusado de violación, Hércules se vio obligado a alejarse de Mégara y esta se prometió con Euristeo. Una vez que Hércules creció y estuvo preparado, volvió a Tebas y se encontró nuevamente con sus hijos, pero Mégara, devota de Hera y presa del mismo odio que Alcmena, quiso deshacerse del padre de sus hijos. Siguiendo pues los consejos de aquella, envenenó a Hércules haciéndole entrar en un estado de locura que le llevó a matar a sus tres hijos. Así, con la necesidad de sanar su culpa y tras consultar a Tiresias en el oráculo de Delfos, se puso al servicio de Euristeo, quien le encargaría los doce trabajos. Este episodio de la locura, tal como expone Ruiz de Elvira (2000),

... es colocado en este momento de la vida de Hércules por Apolodoro (II, 4, 12), Diodoro (Iv, 11, 1-3), Nicolás de Damasco (90F 13 en Constantino Porfirogénito exc. de virtut. I, 337, 13) y Mosco (Mégara vv. 13-16, 41-46); en cambio Eurípides en el Hércules [...] coloca la locura mucho después como posterior a los trabajos; en 


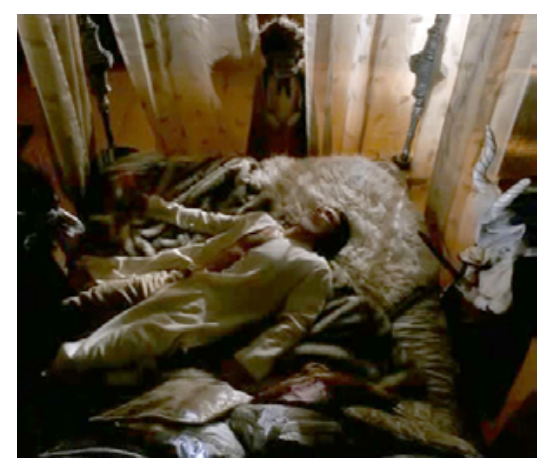

Fig. 9. Hércules en la cama es rodeado por sus hijos, que pretenden matarle.

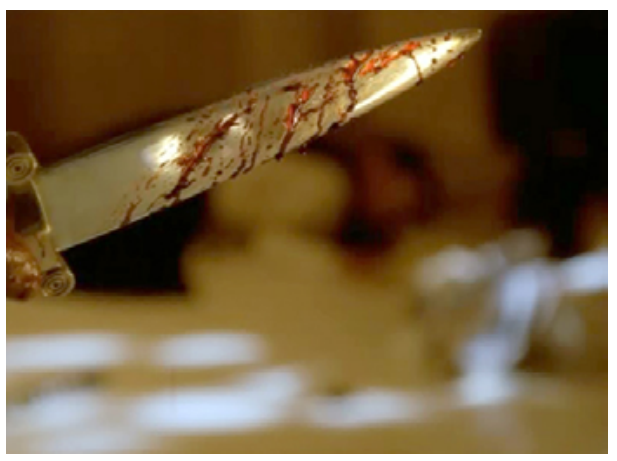

Fig. 10. Puñal ensangrentado con el que Hércules da muerte a sus hijos. Al fondo, se intuye la silueta de uno de los críos, que yace muerto.

Eurípides y sus seguidores, además, Hércules mata también a su esposa Mégara. En Apolodoro [...] Hércules mata a sus hijos, y también a los de Ificles, arrojándolos al fuego; en Eurípides [...] a flechazos y mazazos.

En el film, tras Hércules beber de la copa que Mégara la había servido con el veneno, los tres niños acompañados de Ificles acuden a la alcoba donde se encuentra su padre y comienzan a agredirle (fig. 9). Este, alentado por la voz de su hermano, que le susurra que los niños eran demonios, comienza a atacarlos con golpes y un puñal (fig. 10) hasta matarlos. A diferencia de algunas de las fuentes que exponen que además de a sus hijos mató a los de Ificles y a Mégara, en la película no puede ocurrir esto porque Ificles no tiene hijos y Mégara es, junto con Alcmena, la principal antagonista del personaje de Hércules, lo que supondría un fuerte giro en la trama de la película.

Herido y desolado, el Hércules de Young es cuidado por la ninfa Deyanira -con quien establecerá una relación y tendrá un hijo: Hilo-y acompañado por Linus acude al oráculo de Delfos, donde Tiresias - en la mitología sería este el momento en el que la Pitia le diera el nombre de Heracles- le dice:

Mégara es la esposa de Euristeo. Tú debes entregar tu poder y orgullo al servicio de su gloria. Seis veces debes servirlos, tres veces por tres hijos asesinados y tres veces por Hércules, muerto como un héroe, muerto como un dios, que debe renacer como un hombre.

Así, tras escuchar las palabras del vidente, el héroe regresará y se someterá a las órdenes de Euristeo. En este episodio, como podemos comprobar mediante el diálogo, el film altera el número real de trabajos que el tebano debe realizar. Esta modificación - de doce a seis trabajos- es entendible y lógica si comprendemos que un film, al fin y al cabo y por mucho que pueda alargar su minutaje, está 


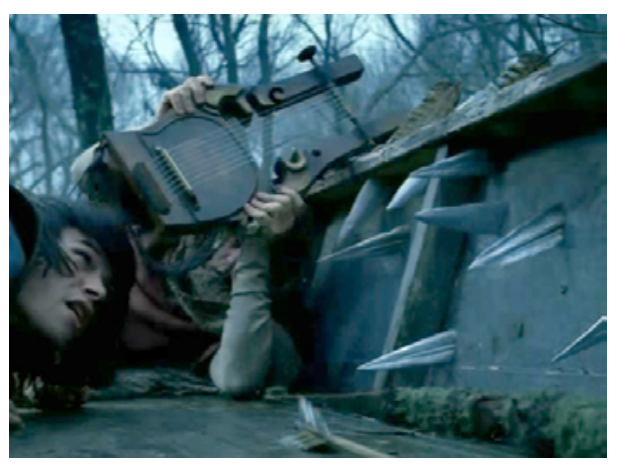

Fig. 11. Hércules y Linus se protegen del ataque de las aves.

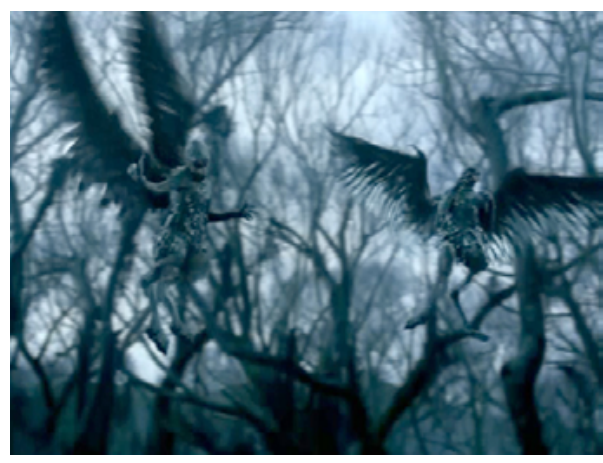

Fig. 12. Las harpías se muestran ante Hércules y Linus.

limitado por el tiempo. Además, esta producción concretamente ha sido, como hemos visto, más explícita, en otros ámbitos de la vida del héroe, lo que hace inevitable reducir esta historia, que, en cierto modo, es la más conocida de Hércules. Es probable que en su versión televisiva, de cuatro horas de duración, los trabajos fueran más, y que para esta versión se modificara el diálogo para ajustarlo al argumento que desarrolla.

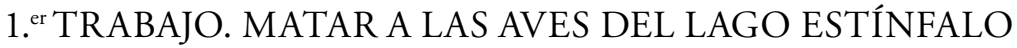

Euristeo ordena a Hércules como primer trabajo matar a las aves de Estinfalia. Para llevarlo a cabo, el joven debe acudir a «la remota tierra de Estinfalia», donde hay un pantano lúgubre debido a la presencia de unas extrańas aves que no permiten que el lugar florezca. Acompañado de Linus, el héroe llega hasta la morada de las aves en una barca y comienzan a «lloverles» plumas afiladas (fig. 11) como cuchillas que intentan matarlos. Las aves, en realidad las harpías que le habían dado el nombre de Hércules, se enfrentan a él, pero este finalmente acaba con ellas a flechazos.

Apolodoro (II, 5, 6) nos cuenta que este fue el sexto trabajo de Heracles y que en la ciudad de Estínfalo había un lago oculto por la vegetación donde se habían refugiado numerosas aves. El hijo de Zeus no sabía cómo hacerlas salir, así que Atenea le facilitó unos crótalos de bronce que hizo sonar en una montańa cerca del lago, y consiguiendo que las aves levantaran el vuelo las aturdió con una flecha.

Nuevamente las harpías (fig. 12) aparecen en el film totalmente descontextualizadas ya que, como adelantamos, estas no tienen relación con la historia de Heracles. Es aceptable, sin embargo, que el film las vuelva a utilizar en este aspecto para reflejar cómo Hércules va ganando terreno sobre las devotas de Hera, que son 


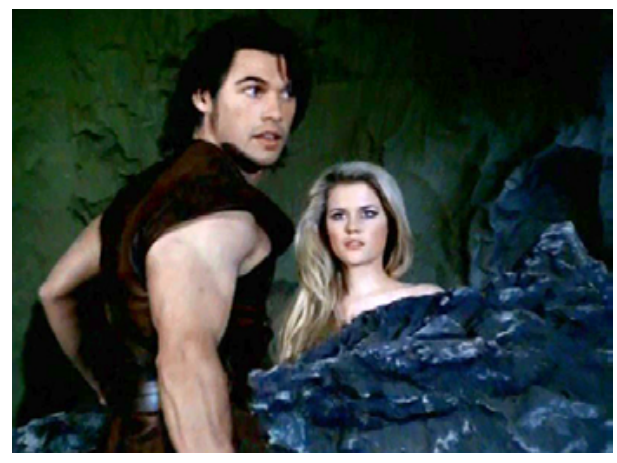

Fig. 13. Hércules y la mujer que habita en la cueva del león de Nemea.

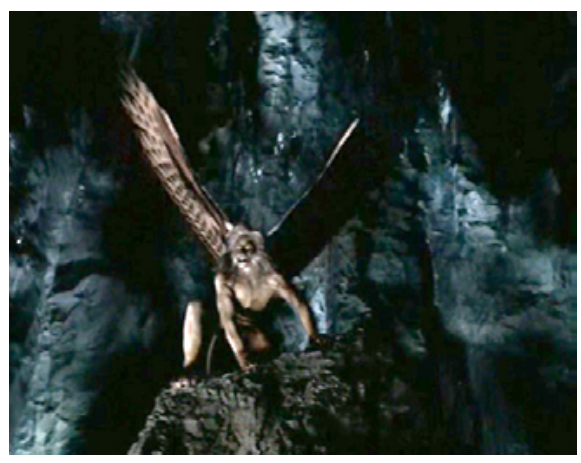

Fig. 14. La mujer transformada en esfinge amenaza a Hércules.

sus enemigas. Además de este aspecto, la película obvia la ayuda que el héroe recibe de la diosa Atenea, porque, como hemos visto, la presencia de los dioses no tiene cabida en este film, y, además, si Hércules se enfrenta a ellas por iniciativa propia, se exalta su carácter invencible y su heroicidad.

\section{2. ${ }^{\circ}$ TRABAJO. MATAR AL LEÓN DE NEMEA Y DESPOJARLO DE SU PIEL}

El segundo trabajo encomendado por Euristeo en el film es el de matar al león de Nemea, una de las hazañas más importantes, y que caracteriza la iconografía del héroe por representársele habitualmente ataviado con la piel de este animal. Según Hesíodo (Teogonía, 327 ss.) el león de Nemea fue criado por Hera, quien lo puso en los montes de Nemea y fue Heracles quien le dio la muerte. Apolodoro (II, 5, 1), por su parte, describe mejor esta escena declarando que cuando Heracles llegó a Nemea, disparó al león primero con flechas, pero como vio que era invulnerable, lo persiguió con la maza. El animal se refugió en una cueva con dos entradas, así que el héroe tapó una de ellas y se enfrentó a la fiera rodeándole el cuello con sus brazos hasta estrangularla. En la película, sin embargo, la hazaña no ocurre exactamente de esta manera. Hércules se adentra en la cueva en la que presuntamente está el león y se encuentra con una joven mujer de cabello rubio (fig. 13), que pide al héroe que se acerque y la bese. Tras obedecer su petición, el joven se atreve a preguntarle por el león y esta, sin permitir una reacción de Hércules, se transforma -según palabras de Linus- en una esfinge (fig. 14). La realidad es que, según los textos, una esfinge griega -diferente a la egipcia- se caracteriza por tener rostro y pecho de mujer; cuerpo, zarpas y cola de león; estar cubierta de plumas y generalmente alada. El ser del film, sin embargo, presenta cuerpo humano -al igual que el Minotauro-cubierto de pelo, cabeza de león y unas alas similares a las de un águila. 


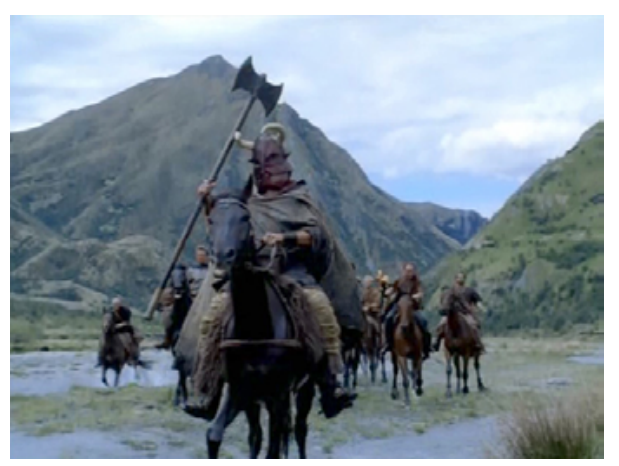

Fig. 15. Anteo como el toro de Creta.

Este cambio, que parece irrelevante, transforma por completo la principal hazaña por la que en la cultura se conoce al héroe griego. Este cambio, quizás, se produce por el interés en buscar un espécimen más espectacular y que se aproxime más a la fantasía que es habitual en un ser «mitológico». Con esto quiero decir que, casi con toda seguridad, el espectador relaciona más fácilmente con la mitología a un animal inexistente y que parece invulnerable que a un simple «león». A este cambio, hay que añadirle, además, la extraña manera en la que Hércules da muerte al animal. Tras intentar abatirlo con flechas -como en los textos-, el fornido joven se enfrenta a la bestia con sus brazos, pero en lugar de estrangularlo con su fuerza hace que esta se abra el pecho con sus propias zarpas.

\section{$3{ }^{\text {er }}$ TRABAJO. CAPTURAR AL TORO DE CRETA}

Según la película, tras haber sido desolada una aldea próxima a Tirinto, Euristeo encomienda a Hércules apresar al toro de Creta y traerlo con vida. Este «toro de Creta» es en realidad Anteo (fig. 15) -hijo de la madre tierra y supuesto padre de Hércules-, que porta un casco con cuernos y, junto con otros hombres, está atemorizando a la población destruyendo sus hogares. Hércules, junto con los hombres de la aldea, se enfrenta a Anteo, lo captura y lo presenta ante el rey, quien lo encerrará en una torre, alejado de la tierra de donde toma la fuerza.

Nada más lejos de la realidad de los mitos. Según Pausanias (Descripción de Grecia I, 27, 9) los cretenses creían que Posidón les había enviado al toro porque Minos rendía menos culto a este dios que a otros. Cuenta en relación con este animal que fue llevado desde la isla hasta el Peloponeso y que constituyó uno de los trabajos de Heracles. Apolodoro (II, 5, 7) expone, sin embargo, que este fue el séptimo trabajo de Heracles y que este se desplazó hasta Creta a buscarlo. Una vez que lo capturó, lo llevó ante Euristeo, quien lo dejó libre provocando que vagara por Esparta, Arcadia e Istmo hasta llegar a Maratón. 


\section{4. ${ }^{\circ}$ TRABAJO. ROBAR LAS YEGUAS DE DIOMEDES}

Expone Eurípides (Heracles, 380 y ss.): «Heracles subió a su cuadriga y con la brida domó las yeguas de Diomedes». Este octavo trabajo, en palabras de Apolodoro (II, 5, 8), corresponde al cuarto que en este caso Mégara encomienda a Hércules en el film. En esta hazaña el héroe debe ir a la isla de Lemos y domar a las yeguas antropófagas trayendo como prueba el ceñidor dorado que lleva la líder de la manada. Después de la travesía lo que Hércules se encuentra en la isla es un grupo de mujeres encabezadas por su reina, Hipólita, que se trasforman en yeguas una vez al año y comen carne de hombre. Así, Hércules y otros voluntarios que le acompañaban se enfrentaron a ellas, «las domaron» y el héroe quitó el ceñidor dorado, destruyéndolo finalmente delante de Mégara y Euristeo para que las yeguas no puedan volver a celebrar su festival sangriento anual. Poco tiene que ver esta escena con los textos clásicos ya que, además de obviar la figura de Diomedes -en Apolodoro II, 5, 8, un tracio hijo de Ares y Cirene y rey de los bístones-, nada se habla en ellos de un grupo de mujeres. Sin embargo, este cambio podría explicarse si examinamos la tendencia constante del film a enfrentar a ambos sexos: Zeus/Hera, Anfitrión/Alcmena, Mégara/Hércules. De esta forma, que el protagonista medie y apacigüe a las mujeres/yeguas habla de su interés por romper con la rivalidad entre ambos géneros. De este modo, su figura nuevamente heroica hace de mediador para conseguir el equilibrio que tanto se menciona durante el largometraje.

Además de esto, como se puede intuir tras la descripción que se ha hecho sobre la escena, este cuarto trabajo encomendado a Hércules en el film incluye-aunque de forma enmascarada- el noveno trabajo expuesto por las fuentes: el cinturón de Hipólita. En este episodio, Heracles tuvo que robar el cinturón de Ares que ostentaba Hipólita, reina de las amazonas, porque la hija de Euristeo quería poseerlo. Tras desembarcar en la isla de Paros, el héroe tuvo un enfrentamiento con los hijos de Minos y cambió su rumbo. Así, Hipólita se presentó antes Heracles para preguntarle por qué le buscaba y le prometió entregarle el cinturón. Sin embargo, Hera, convertida en amazona, comenzó a alarmar a las demás mujeres haciendo creer que su reina había sido secuestrada. Hércules, tras ver como llegaba la multitud contra él y creyendo haber sido engañado, mató a Hipólita, le robó el cinturón y embarcó rumbo a Troya (Apolodoro, II, 5, 9).

\section{5. ${ }^{\circ}$ TRABAJO. CAPTURAR A LA CIERVA DE CERINEA}

Como quinto trabajo, Euristeo quiere poner a prueba a Hércules retándolo a abatir a la cierva de Cerinea -animal vinculado a su esposa Deyanira y a su hijo Hilo, de quien es su animal de compañía-. Aceptando el reto, se adentran en el bosque con el fin de dar caza al animal. Hércules, que no quiere dañarlo, siéndole fiel a su hijo, le dispara una flecha entre los tendones y los huesos y así gana a Euristeo y consigue que la cierva salga ilesa. Esta idea de piedad que muestra el protagonista surge directamente de las fuentes y es que, como cuenta Apolodoro, Heracles, para no herir ni matar a este animal consagrado a Artemis, lo persiguió durante un año 
entero hasta que la cierva cayó fatigada y pudo llevarla viva hasta Micenas, tal como pidió Euristeo. Aunque en la fuente no existe la competición entre Euristeo y Hércules. Lo que pretende el film con esta modificación, además de incrementar la rivalidad entre los dos hombres, es mostrar la mezquindad del rey que pretende matar al animal con el que Hilo, que es solo un niño, está tan unido. De esta manera, el espectador recrea inmediatamente una imagen mezquina del villano y una imagen bondadosa del héroe.

\section{6. ${ }^{\circ}$ TRABAJO. CAPTURAR AL CAN CERBERO Y SACARLO DE LOS INFIERNOS}

El sexto y último trabajo del Hércules de Young supone ir en busca de Cerbero, el perro de tres cabezas que cuida la entrada al Hades, y traerlo hasta Tirinto. Sin embargo, cuando Hércules llega hasta el río Estigia y se adentra en la cueva donde debiera estar el can no hay rastro de él, encontrándose en su lugar a Anteo, a quien se enfrentará y dará muerte. Sabiendo que Anteo ha sido el principal obstáculo de Hércules y el único que, por su físico, se puede enfrentar al fornido héroe, es razonable que su personaje se «recicle» y encarne más de uno de los trabajos que este tiene que realizar. En este sentido, Anteo, siendo para el protagonista un rival difícil, hace que con su derrota se glorifique aún más la figura de Hércules y sus trabajos concluyan de forma victoriosa.

Además de estos seis, a lo largo del film se desarrollan, aunque no como tales, otros de los trabajos que se le atribuyen a Heracles dentro de los textos clásicos. Así, podemos contemplar en otras escenas del metraje la lucha contra el jabalí Erimanto y el duelo contra la hidra de Lerna.

- El jabalí de Erimanto. Estando ya exiliado en las montañas a cargo del ganado de su padre, Hércules, con el fin de demostrar su hombría, intentó - corriendo tras él- dar caza al jabalí que espantaba a las reses que estaban bajo su responsabilidad. Unido pues a Anfitrión, Ificles, Mégara, Euristeo y Teseo, el aún adolescente héroe se enfrentó cuerpo a cuerpo al animal (fig. 16) que denominan "Colmillo Mellado", saliendo herido de la reyerta. Fue realmente la ninfa Deyanira quien lo abatió con un flechazo - con el fin de salvar a Hércules-y Euristeo quien lo mató definitivamente clavándole una lanza. Como se hace obvio, las fuentes no recogen esta escena como una cacería conjunta. De este modo, el considerado como cuarto trabajo fue realizado únicamente por Heracles, quien no dio muerte al animal (Apolodoro II, 5, 4).

- La hidra de Lerna. Pasaron los años y, aislado en las montañas, Hércules se entrenó a diario cargando un caballo a sus espaldas, convirtiéndose así en un joven fuerte. Siendo ya todo un hombre, la ciudad de Tebas estaba amenazada por la presencia de un ser aterrador, la hidra de Lerna, que en el film se nos presenta con aspecto de monstruo marino de dos cabezas. Creyendo el joven que esta era una buena oportunidad para ganarse la gracia de la población de su ciudad natal, acudió a enfrentarse al monstruo. Una vez allí, Hércu- 


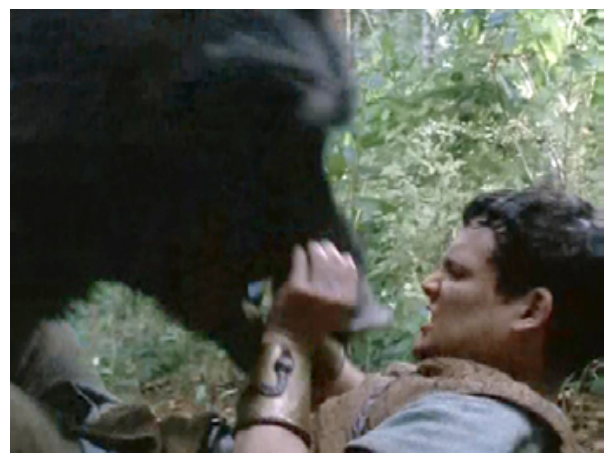

Fig. 16. Hércules adolescente forcejeando con Colmillo Mellado (jabalí de Erimanto).

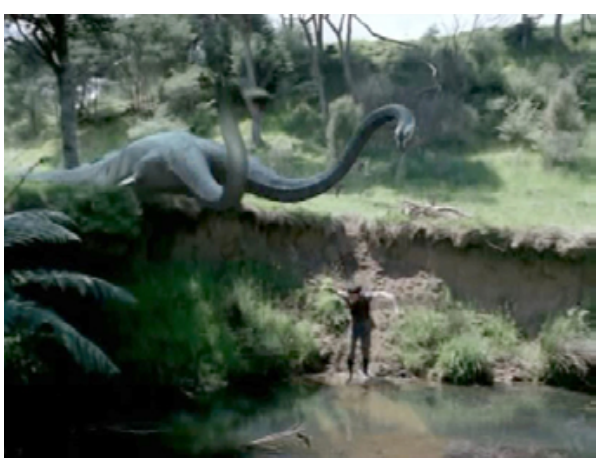

Fig. 17. Hércules enfrentándose a la hidra de Lerna.

les se enfrentó a la hidra (fig. 17), a la que, al igual que en las fuentes, se le multiplicaban las cabezas si se le cortaba una. Por ello, Hércules, que además de en fuerza había crecido en astucia, mandó a Linus a quemar los cuellos de las cabezas cortadas para que no se pudieran reproducir. Ya muy debilitada, Hércules da muerte a la hidra con un tronco de árbol que, en cierto modo, se puede relacionar con el garrote o la maza que se vincula con el héroe mitológico como atributo iconográfico.

Según Hesíodo (Teogonía, 313 y ss.):

... la perversa Hidra de Lerna, a la que alimentó Hera, diosa de blancos brazos, irritada terriblemente con el fornido Heracles. La aniquiló el hijo de Zeus con su implacable bronce, el Anfitriónida Heracles, con ayuda del belicoso Yolao, según los planes de Atenea amiga de botín.

Las palabras de Hesíodo sin duda hacen alusión a la hazaña del héroe griego, pero sin embargo es el texto de Apolodoro (II, 5, 2) el que nos permite hacer una conexión más lógica y coherente con la escena del film. Así, según este:

De nada servía golpear las cabezas con la maza, pues cuando aplastaba una surgían dos. [...] pidió ayuda a Yolao, quien, después de incendiar parte de un bosque cercano, con los tizones quemó los cuellos de las cabezas e impidió que resurgieran. Evitada así su proliferación cortó la cabeza inmortal...

En ambos casos, se nos habla de la presencia y ayuda de Yolao. En el film, por su parte, esta figura es sustituida por la de Linus y tiene sentido si contamos con que inmediatamente después de esta escena, el que fuera maestro de música del héroe se entregará como fiel servidor y será quien le acompañe en todas las aventuras del resto de su vida. 


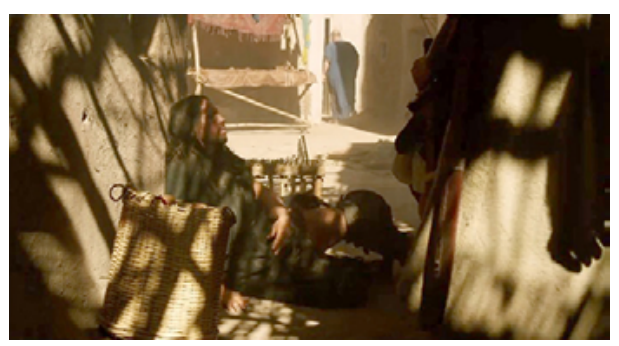

Fig. 18. Hércules ebrio tirado en las calles de la ciudad.

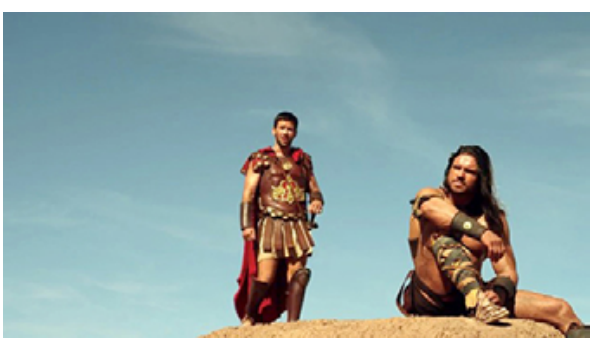

Fig. 19. Hércules y Arius antes de enfrentarse al rey Nicos.

\section{HERCULES REBORN (2014), NICK LYON}

En este largometraje dirigido por Nick Lyon, el personaje de Hércules queda absolutamente descontextualizado del mito que nos exponen las fuentes. Podemos afirmar en realidad que no hay rastro en absoluto de la personalidad de nuestro héroe, y que su nombre se usa como excusa para dar rienda suelta a la imaginación de los guionistas, los cuales introducen personajes que no existen en este mito, ni en ningún otro de las fuentes clásicas -Nicos, Aticus Dudunakus, Timek...-. A pesar de esto, y de la gran distorsión que sufre la historia, en esta producción se puede establecer una única conexión con el mito, y es, aunque no por la misma causa, la muerte de Mégara y sus hijos. En relación con esto, Hércules, mata a su esposa e hijos porque Nicos, enamorado de Mégara, hace que el héroe ingiera una poción que lo vuelve loco y agresivo lanzando una escultura de piedra contra su familia, causándole la muerte. Como ya hemos comentado respecto a este episodio, Apolodoro (II, 12, 1) expone que

después del combate contra los minias, Hera, celosa, lo enloqueció y Heracles arrojó al fuego a sus hijos habidos con Mégara y a dos de Ificles; por ello se condenó a sí mismo al exilio y, purificado por Tespio, marchó a Delfos y preguntó al dios dónde debería vivir.

En este film se pretende mostrar a un Hércules destruido después de su vida gloriosa. Así, lo que podemos ver en él es un Hércules retirado de la "vida pública», ahogado en el alcohol (fig. 18) y destrozado por haber matado a su esposa e hijos. Hércules es aquí el antihéroe tan característico del cine de las últimas décadas. Es inquietante cómo en una película de estas características se ha caído en uno de los mayores tópicos del cine y de la vida en general: un héroe -o un hombre de éxitofrustrado se refugia en el alcohol -o cualquier tipo de estupefaciente- para ser rescatado (fig. 19) y renacer de sus cenizas como un ave fénix.

A pesar de esta condición, que es la que primeramente nos muestra el largometraje, su figura sigue creando expectación y sus hazańas del pasado hoy se cuentan 


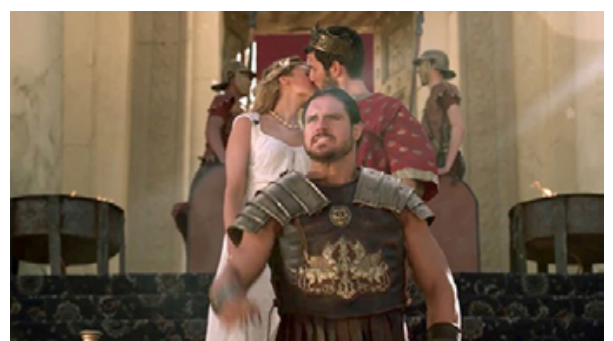

Fig. 20. Hércules se planta victorioso frente al pueblo que le aclama por librarle de un rey tirano.

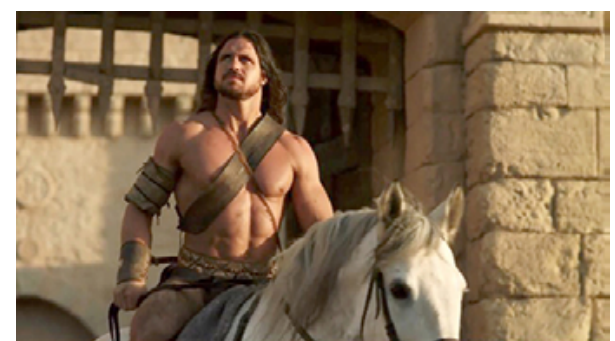

Fig. 21. Hércules «renacido», marcha rumbo hacia una nueva vida.

como leyendas entre los jóvenes. Lo cierto es que Aticus, nuestro personaje principal, que se concibe ahora como el héroe del héroe y quizás un alter ego del antiguo Hércules, sabe que este existe realmente y por ello acude en su búsqueda para que luche con él y salvarlo de su versión más denigrante.

\section{THE LEGEND OF HERCULES (2014), RENNY HARLIN}

The Legend of Hercules (Hércules: el origen de la leyenda), es la segunda producción cinematográfica realizada en el año 2014 sobre el héroe heleno hijo de Zeus y Alcmena. Este film se inicia ubicando al espectador en medio de una batalla en la localidad de Argos en el año 1200 a.C. donde finalmente se baten en duelo el rey Galeano de Argos y el rey Anfitrión de Tirinto. A este último, la película lo presenta como un tirano y codicioso rey, por lo que Alcmena, su mujer, temerosa por el hijo que tienen en común, Ificles, y por la reacción de los dioses ante la actitud de su esposo, reza a Hera para que esta medie ante su rey. Así, la diosa se presenta en forma humana a ella y su tutor Quirón y le pregunta a la mortal si está dispuesta a traicionar a su esposo para tener un hijo de Zeus y conseguir la paz en su tierra. De esta manera, Hera anuncia a Alcmena que concebirá a un hijo de Zeus y que ella le conocerá siempre como Hércules. Así, en forma de tormenta eléctrica, Zeus toma a la mortal mientras está en su lecho y engendra al héroe que traerá la paz.

Tras la gestación, Alcmena da a luz a su segundo hijo y Anfitrión, que sabe que no es suyo y le ha declarado "la guerra» a Zeus, dice ante su esposa: «Se llamará Alcides y nunca se tratará como un igual a su hermano mayor».

Como vemos, este film, dirigido por Renny Harlin, hace una lectura no muy fiel de la concepción y el nacimiento de Heracles que exponen las fuentes clásicas. De acuerdo a estas, como hemos visto ya anteriormente, Heracles es concebido por un «capricho» de Zeus y nada tiene que ver Hera, que, contrariamente a la película, actuará en contra del muchacho toda su vida y, por supuesto, no mediará para que Alcmena geste en su vientre a un hijo de su esposo. En este aspecto, aunque parezca 
que el cambio de rol que sufre Hera en el film con respecto a las fuentes no tiene cabida, lo cierto es que puede tenerla si nos paramos a pensar que, contrariamente a Anfitrión, Alcmena venera y defiende a los dioses. Además, cuando pide ayuda para acabar con la tiranía y mezquindad de su rey es a una representación de Hera a la que le ora. De ahí, quizás, el porqué de que sea esta diosa la que, en el film, media en la concepción de Hércules, convirtiéndose de algún modo en la salvadora.

A pesar de las modificaciones, este film introduce un aspecto que ningún otro de este siglo hace: presentar al héroe con su verdadero nombre de pila. Aunque parezca intrascendente, este hecho es curioso y diríamos incluso que atrevido, ya que el nombre de Hércules está tan arraigado en la cultura universal que, a excepción de las personas que trabajan, estudian o se interesan de manera profunda en la mitología, la mayoría del público podría no llegar a entender el «cambio» de nombre y considerarlo incluso "gratuito». Lo cierto es que el verdadero nombre de Heracles era, según los mitógrafos, Alcides o Alceo, viniendo este de su abuelo paterno. En palabras de Diodoro de Sicilia (I, 24, 4): «El de Alcmena [...] fue llamado Alceo al nacer y más tarde se le cambió el nombre por el de Heracles». Sin embargo, Apolodoro (II, 4, 12), por su parte, expone: «La Pitia entonces lo llamó por primera vez Heracles, pues antes era conocido por Alcides [...]». Este aspecto, recogido por el film, es especialmente interesante ya que, tal como expone Dan Curley (2018): "... the movie delves into Hercules' backstory and thus breaks with the cinematic norm of the fully formed and seasoned herom. ${ }^{13}$

Veinte años más tarde, según el film, Alcides, ya en la etapa adulta y con un cuerpo notablemente atlético, establece una relación sentimental con la princesa Hebe, hija del rey Tallas de Creta. Sin embargo, su hermano Ificles, celoso de la pareja, convencerá al rey Anfitrión -que detesta firmemente a Hércules-para que rechace la unión de ambos y sea él quien despose a la princesa. Lo cierto es que en la mitología Heracles y Hebe se unen en matrimonio (Ovidio, Fastos vi, 65) después de que este realice su última hazaña, la cual le llevará a la muerte terrenal: la lucha en Ecalia. Según las fuentes, tras la victoria, pretende hacer un sacrificio de acción de gracias a Zeus y ordena a Deyanira -su esposa por entonces- que le haga llegar su atuendo para los sacrificios. Así, la ninfa, que estaba insegura de que Heracles la amara, impregnó la capa con un filtro ${ }^{14}$ que el centauro Neso antes de morir le había aconsejado. Lo que no sabía Deyanira es que realmente la sangre de Neso estaba envenenada suponiendo su filtro un verdadero ungüento tóxico. Así, cuando Heracles puso la túnica sobre sí se le quemó la piel causándole terribles lesiones incurables y, debido a su gran dolor, pidió que le hicieran arder en una pira en el monte Eta. De este modo, con las llamas, murió su parte mortal y la inmortal subió al Olimpo. Es en este momento cuando, tras reconciliarse con Hera, toma en matrimonio a Hebe,

${ }^{13}$ La película se adentra en la historia de Hércules y rompe así con la norma cinematográfica del héroe plenamente formado y experimentado. Traducción de la autora.

${ }^{14}$ Una especie de poción hecha con el semen y la sangre del centauro Neso mezclada con aceite. 


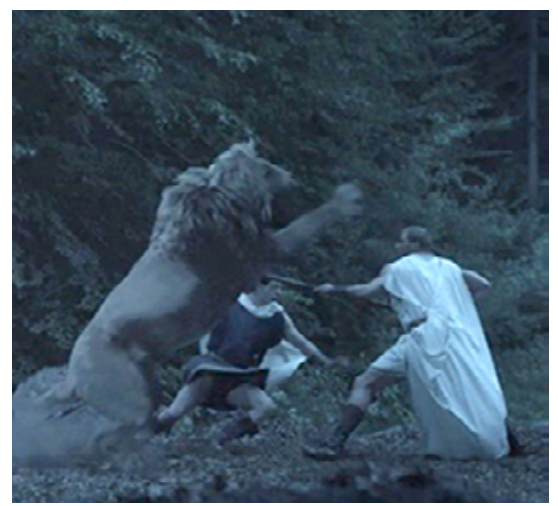

Fig. 22. Hércules intentando clavar una lanza al león.

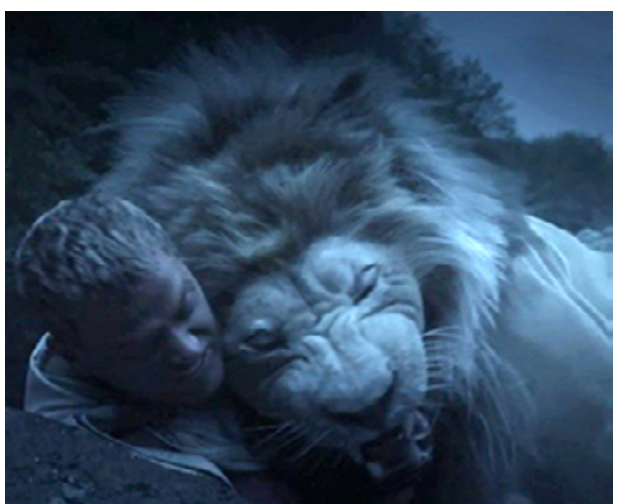

Fig. 23. Hércules ahogando al león con sus propios brazos.

hija de la diosa, con la que, según Apolodoro (II, 7, 7), tendrá dos hijos: Alexíares y Aniceto $^{15}$. En palabras de Diodoro de Sicilia (Iv, 39, 2):

... después de su apoteosis, Zeus persuadió a Hera para que adoptase a Heracles como hijo y le diese un afecto maternal durante todo el resto de los tiempos. Esta adopción se realizó, dicen, del modo siguiente: Hera se subió al lecho y, tras atraer junto a su cuerpo a Heracles, dejó que se deslizara al suelo a través de sus vestidos, imitando un verdadero nacimiento. Esto precisamente es lo que hacen los bárbaros hasta nuestros días cuando quieren adoptar un hijo. Después de la adopción, Hera, cuentan los mitos, unió a Heracles en matrimonio a Hebe.

Además de esta relación, la producción, antes de modificar por completo la historia del héroe, mandándolo a luchar a Heliopolis (Egipto) y ser vendido como gladiador, hace alusión a uno de los doce trabajos que exponen las fuentes: el enfrentamiento al león de Nemea. Así, Alcides, paseando a caballo con su hermano mayor Ificles, se encuentra por casualidad con el león de Nemea, al que sin dudarlo hace frente. Tras enfrentarse a él con lanzas (fig. 22) y ver que su dura piel no permite que la moharra ${ }^{16}$ le dañe, Alcides se enfrenta al enorme animal con sus propias manos (fig. 23) y lo mata apretándole el cuello hasta estrangularlo. Aunque como vemos la historia no ocurre como exponen las fuentes, en esta hazaña el film es fiel a la hora de mostrar la forma en la que el héroe da muerte a la fiera. De este modo, aunque varía el resto del trabajo, con esta acción la película consigue subrayar el lado sobre-

15 Al final de la película Hebe y Hércules tienen un hijo.

${ }^{16}$ Como se denomina la punta metálica de una lanza. 


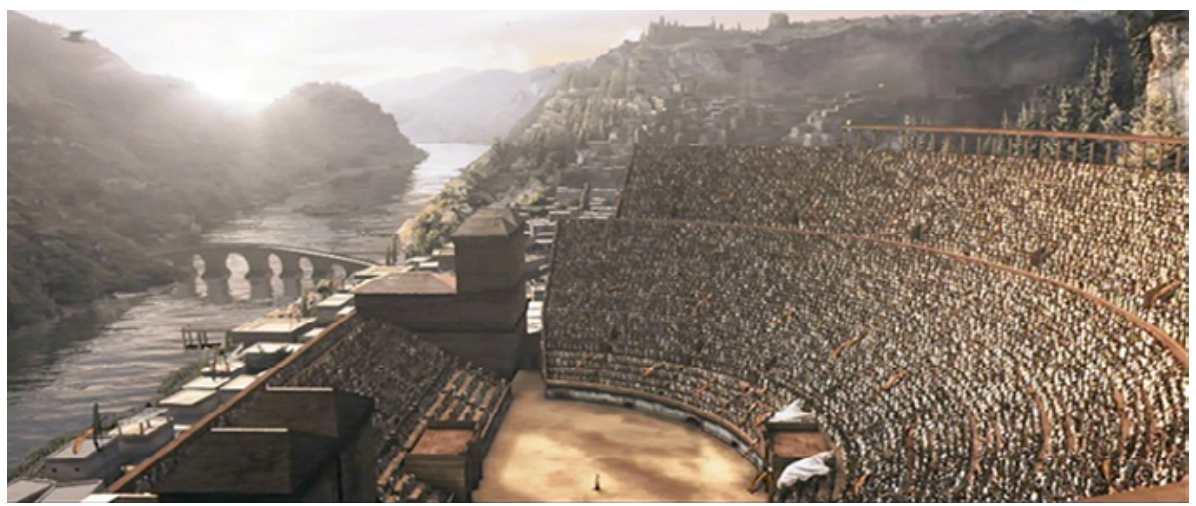

Fig. 24. Teatro que recoge la última lucha de Hércules como gladiador.

humano y la fuerza espectacular del personaje, aspectos principales que interesan de la figura de Alcides para este tipo de adaptaciones.

Tras esta hazaña, Anfitrión anuncia que Hebe deberá desposarse con el heredero del trono de Tirinto, Ificles, condenando así su unión con Alcides. La pareja, aturdida por la decisión del rey, que va en contra de su voluntad, huye con el deseo de formar una nueva vida juntos. Sin embargo, son apresados y Hércules, por desobedecer las órdenes de su rey, es enviado - como ya adelantábamos-a luchar con los soldados del ejército de Tirinto al estrecho de Osiris en Egipto ${ }^{17}$. Allí, serán vencidos y los dos únicos supervivientes, Alcides y Sotiris - general del ejército-, son capturados por Tarak, cabeza del ejército enemigo. Este los venderá como esclavos y pasarán a pertenecer a un lanista ${ }^{18}$ que los llevará de un lado para otro como gladiadores. Respecto a este detalle, nos vemos en la obligación de aclarar que si tenemos en cuenta que la película nos sitúa desde el principio en el año 1200 a.C. y pasan 20 años hasta que Alcides e Ificles son adultos, esta escena tendría lugar aproximadamente en el año 1180 a.C., por tanto habría que matizar que el tráfico de gladiadores ocurre siglos más tarde, desde el siglo vi a.C., cuando los milicianos etruscos luchaban entre sí para honrar a los difuntos de las clases influyentes de la sociedad, y que este "comercio» nada tiene que ver con los griegos. Nuevamente, pues, se trata de una licencia que se toman los guionistas y el director del film conduciendo la historia hacia una absoluta descontextualización.

Este hecho en realidad es más propio de lo que parece de este tipo de péplums. Es frecuente que en estos films recreados en la antigua Grecia se incluyan algunos aspectos de, principalmente, la cultura y la historia de Roma, que poco o nada tie-

${ }^{17}$ Esta escena nos recuerda de forma clara a la lucha que se desarrolla entre Leónidas (y los espartanos) contra los persas en el film de Zack Snyder, 300.

${ }_{18}$ Propietario y formador de gladiadores. 
nen que ver con ella. Este ejemplo suscitado en Hércules: el origen de la leyenda es solo uno de los muchos que se producen en películas de esta índole. Lo cierto es que la civilización romana ha llegado hasta nuestros días con estudios mucho más amplios y profundos que la griega, y también lo es que somos conocedores de la civilización helena gracias a que los romanos tomaron muchos aspectos de ella. Sin embargo, no debemos olvidar que entre ambas culturas también hay divergencias que las hacen más diferentes de lo que se cree de manera general.

Regresando nuevamente al film, tras haber viajado por diferentes partes del mundo como gladiador, nuestro protagonista se fue fraguando una reputación dentro del mundo de los combates bajo el nombre de Hércules, regalo de Hera. Finalmente el héroe llega a Tirinto, donde pide a su dueño la libertad si consigue salir victorioso contra los seis gladiadores más fuertes de toda Grecia. Así, Hércules, junto con Sotiris y su antiguo ejército, luchará contra el tirano Anfitrión y su hijo Ificles, encabezando pues una revolución ante un rey nefasto. Finalmente, aceptando ser hijo de Zeus, Hércules se enfrenta a su "padre» en la tierra y vence a su mezquindad y avaricia.

En este film, pues, Hércules pasa de ser un héroe de hazañas sobrehumanas a un soldado que lucha por el cometido para el que, según Hera, había nacido: conseguir la paz en su tierra. En definitiva, estas características que sigue el personaje del film son más propias de la concepción que se tiene sobre el héroe ya en la civilización romana: «En Roma, la leyenda que se impuso en la época clásica es una aplicación del esquema de la lucha victoriosa del héroe benefactor contra el "malvado" malhechor» (Bonnefoy, 1997).

\section{HERCULES (2014), BRETT RATNER}

«¿Creéis que sabéis la verdad sobre él? No sabéis nada». Este film dirigido por Brett Ratner supone la última producción que se ha realizado en el siglo xxı en relación con el mito del héroe griego. En ella, una voz en offinicia el metraje y actúa como narrador omnisciente poniendo en contexto al espectador describiendo supuestos hechos de la vida del protagonista. De este modo, a medida que habla el relator, se nos presenta al personaje principal como un semidiós hijo de Zeus y Alcmena, odiado por la mujer del dios, Hera, la cual considera a este niño como un insulto y el vivo recuerdo de la infidelidad de su esposo. Alcmena, con el fin de apaciguar el odio de la diosa, llamó a su hijo Hércules, que significa gloria de Hera, como ya vimos; sin embargo, esto no consiguió calmar a la diosa, que continuaba deseando su muerte. A la par que se nos narra esta última frase, el film nos muestra a dos serpientes saliendo de los ojos de una estatua de Hera (fig. 25) y cómo las mismas se deslizan hasta la cuna del niño -ya con unos cuantos años- y este las estrangula con sus manos. Lo cierto es que, como ya hemos comentado, en las fuentes es efectivamente Hera quien manda los dos reptiles para intentar acabar con el niño ilegitimo; sin embargo, a diferencia de lo que vemos en el film, este era solo un recién nacido -o, como exponen otros, tendría solo 8 o 10 meses-. 


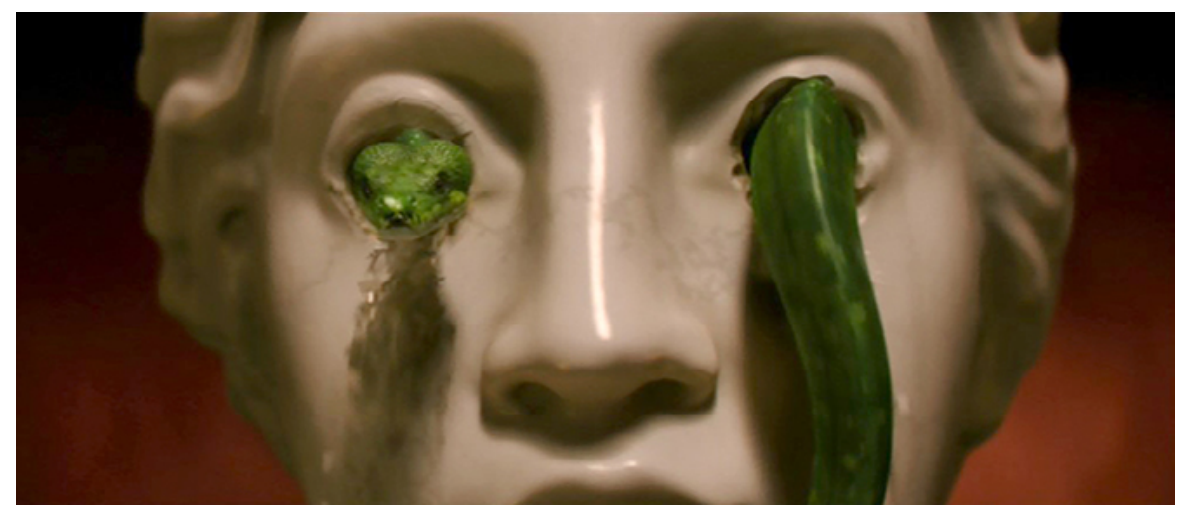

Fig. 25. Serpientes saliendo de los ojos de una estatua de Hera con intención de acabar con el pequeño Hércules.

Ya en la madurez, según continúa exponiendo el narrador en el film, a Hércules los dioses -según la mitología es Euristeo- le encomendaron doce trabajos, cumplidos los cuales, si sobrevivía, Hera accedería a dejarlo vivir en paz al fin. Entre ellos, la voz en off explica, mientras somos testigos de las hazańas, tres de los trabajos: la hidra de Lerna, el jabalí de Erimanto y el león de Nemea.

- La hidra de Lerna. En una especie de pantano Hércules sigilosamente porta una espada y cuando aparece la hidra se enfrenta a ella cortándole las cabezas. De este ser, no podemos identificar más que las partes que sobresalen del agua, distinguiendo así cinco cabezas con un aspecto similar a la de un dragón.

En los textos son diferentes las descripciones que se hacen sobre la hidra. Así, se habla que esta podría tener cien (Diodoro de Sicilia Iv, 11, 5), mil (Eurípides: Heracles, 419 y ss.) u ocho o nueve cabezas. En palabras textuales de Apolodoro (II, 5, 2):

Como segundo trabajo le ordenó matar a la Hidra de Lerna. Ésta, criada en el pantano de Lerna, irrumpía en el llano y destruía el campo y los ganados. La Hidra tenía un cuerpo enorme, con nueve cabezas, ocho mortales y la del centro inmortal. [...] De nada servía golpear las cabezas con la maza, pues cuando aplastaba una surgían dos. Un enorme cangrejo favorecía a la Hidra mordiendo el pie de Heracles. Él lo mató y luego pidió ayuda a Yolao, quien, después de incendiar parte de un bosque cercano, con los tizones quemó los cuellos de las cabezas e impidió que resurgieran. Evitada así su proliferación cortó la cabeza inmortal, la enterró y le puso encima una pesada roca, cerca del camino que través de Lerna conduce a Eleúnte. Abrió el cuerpo de la Hidra y sumergió las flechas en su bilis...

- El jabalí de Erimanto. En un bosque nevado, Hércules y un jabalí de descomunales dimensiones y tres pares de colmillos se enfrentan cara a cara. El semidiós consigue darle muerte golpeándolo con su mazo en la cabeza. 
En las fuentes, por el contrario, el héroe no debía matar al animal ya que el rey Euristeo lo pidió vivo ante él.

... cuando oyó la noticia de que los héroes se reunían, apenas hubo recorrido el camino de la Arcadia a Argos Lircea, por donde traía vivo el jabalí que pastaba en los valles de Lampea por la vasta marisma del Erimanto, de sus anchas espaldas lo descargó, envuelto en ataduras, a la entrada de la plaza de Micenas, y él por propia voluntad contra los planes de Euristeo partió (Apolonio de Rodas, Argonáuticas, I, 127).

- El león de Nemea. Según el narrador este es su mayor trabajo. En el interior de una cueva, Hércules se encuentra con un gigantesco león que no se inmuta en absoluto con las flechas que aquel le dispara, por ello enfrentándose a él cuerpo a cuerpo lo derrota rompiéndole la mandíbula.

Como ya sabemos, lo que nos transmiten las fuentes sobre este tema es que Heracles dio muerte a la fiera con sus propias manos, pero no dislocándole el maxilar inferior sino apretándole el cuello hasta estrangularlo.

Aunque los trabajos hayan sido narrados y mostrados en el comienzo del film -más tarde también mencionarán las manzanas de las Hespérides y el cinturón de Hipólita-, lo cierto es que la trama de la película nos hará ver que estos son una ficción para el «verdadero» Hércules. En este sentido, el hijo de Zeus se presenta como un mercenario cazarrecompensas que trabaja para reyes de toda Grecia en compañía de Autólico ${ }^{19}$, Atalanta ${ }^{20}$, Anfiarao ${ }^{21}$, Tideo $^{22}$ y Yolao. Este último es sobrino de Hércules -al igual que en las fuentes, pues es hijo de Ificles- e historiador - de ahí que sea el narrador que recita los trabajos de su tío-. Con esto, el largometraje nos presenta a un Hércules mitológico, pero sin serlo verdaderamente. Es decir, el Hércules de Rattner es un mercenario extremadamente fuerte, luchador y guerrero cuya fama, cantada por Yolao, se inspira en las hazañas del héroe de las fuentes clásicas, aunque no está claro que el de la película las haya vivido. En relación con esto Curley (2018) plantea que

Hercules goes further and adopts the atheistic approach of Troy, not only keeping divinities off screen, but also obscuring all evidence of their being. Both gods and

19 En la mitología, Autólico fue quien enseñó a Heracles, en su juventud, el arte de la lucha.

20 Atalanta es una heroína de la mitología que fue abandonada por su padre en el bosque, siendo amamantada por una osa hasta que la rescataron unos cazadores y la criaron. Ya de adulta se mantuvo virgen y, al igual que Ártemis, se dedicó a cazar en los bosques. Este personaje no tiene ningún tipo de relación con el mito de Heracles.

${ }_{21}$ Anfiarao tampoco tiene vínculo con el mito del héroe tebano, sin embargo, las características del personaje del film coinciden con las del mitológico. Así, Anfiarao era realmente un vidente que gozaba de la protección de Zeus y Apolo y, del mismo modo, era un jefe guerrero.

22 Tideo es un héroe procedente de Etolia y tampoco su historia se cruza con la de Heracles. Su mayor leyenda se resume en la lucha de los Siete Jefes contra Tebas. 


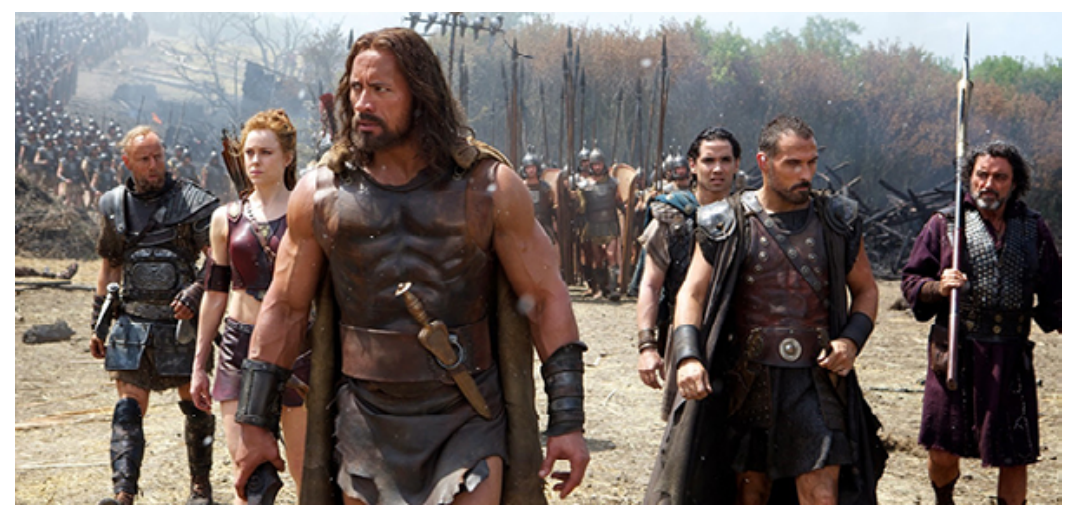

Fig. 26. Equipo de Hércules. De izquierda a derecha:

Tideo, Atalanta, Hércules, Yolao, Autólico y Anfiarao.

monsters are confined to the world of mere stories [...].By revealing Iolaus' story as fiction, Hercules programmatically sunders itself from conventional cinematic monomyth in favour of antiheroic «reality» ${ }^{23}$.

El film tiene pues como protagonista a un Hércules huérfano que intentó sobrevivir en Atenas y que encontró un lugar de refugio en el ejército. Su fuerza llamaba la atención y fue ganando fama haciendo creer en su procedencia divina y sus hazañas contra los monstruos del mito griego. De esta forma, la producción se centrará en su actividad como cazarrecompensas y su trabajo para el rey Cotis ${ }^{24}$ -quien más tarde le traicionará-, enfrentado con Reso ${ }^{25}$, un presunto rey rebelde.

A pesar de esta descontextualización del mito y de la insistencia en presentarnos a un Hércules muy humano, diferente al de las fuentes, existe en la película un vínculo entre los dos héroes: la muerte de Mégara y sus hijos. En este sentido, al Hércules del film se le acusa de haber matado a su familia y tiene constantes pesadillas con un acontecimiento que, a pesar de no recordarlo fielmente, está relacionado con su mujer, sus hijos y el perro Cerbero. En realidad, el film nos desvelará más tarde que este hecho ocurrió debido a que Euristeo - rey para el que nuestro héroe había trabajado anteriormente- drogó a Hércules y soltó a tres lobos que mataron a su familia sin que él pudiera evitarlo debido a su estado.

${ }^{23}$ Hércules va más allá y adopta el enfoque ateo de Troya, no solo manteniendo a las divinidades fuera de la pantalla, sino también ocultando toda la evidencia de su ser [...]. Al revelar la historia de Yolao como ficción, Hércules se desvía programáticamente de los monomitos cinematográficos convencionales en favor de la «realidad» antiheroica. Traducción de la autora.

${ }^{24}$ Cotis I fue un rey tracio de aproximadamente el siglo iv a.C. Su relación con Heracles es inexistente.

${ }^{25}$ Sin relación alguna con Heracles, Reso fue un héroe tracio que luchó con los troyanos en la guerra de Troya y alcanzó la muerte de mano de Ulises y Diomedes. 
Además de este posible nexo con las fuentes, al final del metraje Hércules tras ser capturado por Euristeo y Cotis -aliados-y atado a unas columnas -que romperá como lo hizo Sansón en el templo de los filisteos- se enfrentará a tres lobos que encarnan realmente a la figura de Cerbero. Aunque ciertamente en el film no se tome como tal y no se recree en absoluto lo expuesto en las fuentes escritas, este fue el último trabajo que realizó Heracles para Euristeo. En relación con él, Apolodoro (II, 5, 12) expone:

Como duodécimo trabajo se le ordenó traer del Hades a Cerbero. Este tenía tres cabezas de perro, cola de dragón y en el dorso cabezas de toda clase de serpientes. [...] Heracles cubierto con la coraza y con la piel del león, lo encontró a las puertas del Aqueronte, rodeó con sus brazos la cabeza de la bestia, y aunque lo mordió la serpiente de la cola no lo soltó, oprimiéndolo y ahogándolo, hasta que se hubo rendido [...] una vez mostrado el Cerbero a Euristeo, lo volvió al Hades.

\section{CONCLUSIONES}

En las páginas precedentes hemos realizado un estudio del modo en el que el séptimo arte producido durante el presente siglo ha asumido e interpretado la historia de uno de los más celebres hijos mortales de Zeus. Estos films, que se consideran herencia directa de los péplums italianos de los años 50 y 60 , y que se pueden encasillar dentro del neopéplum, muestran de manera general características propias y siguen, en cierta medida, el mismo esquema.

Uno de los aspectos principales y comunes a tres de las cuatro producciones estudiadas es el planteamiento de las mismas partiendo de la base del evemerismo. Esta teoría surgió en el siglo IV y defiende la visión de los dioses clásicos desde un punto de vista más lógico y racional. De este modo, el evemerismo explica que los dioses fueron en su origen humanos mortales que a causa de sus hazañas heroicas, su fuerza y su inteligencia, con el paso del tiempo fueron deificados y mitificados. Así, bajo este credo, se puede explicar que en Hercules (2005), a pesar de mantenerse vigente el conflicto entre divinidades, el héroe mitológico sea en realidad hijo del mortal Anteo. Tal como exponen Patricia Salzman y Jean Alvares (2018):

While we see centaurs, satyrs, and various monsters, the gods themselves never appear, and Hercules comes to realize that the excesses of Greek religion are human abominations, not divine commands. [...] As happens in several movies, this Hercules embraces the moral condition, helps end long-standing conflicts, and embraces a newer, more moral view of divinity ${ }^{26}$.

${ }^{26}$ Mientras vemos centauros, sátiros y monstruos variados, los dioses nunca aparecen en sí mismos, y Hércules llega a darse cuenta de que los excesos de la religión griega son abominaciones humanas, no órdenes divinas. [...] Como sucede en varias películas, este Hércules se acoge a la condición moral, ayuda a poner fin a conflictos de larga duración, y ampara una visión renovada y más moral sobre la divinidad. Traducción de la autora. 
Lo mismo ocurre con Hercules Reborn (2014) y Hercules (2014), en las que los dioses no aparecen, no hay rastro de seres mitológicos y, además, Hércules es concebido como un ser muy humanizado con problemas y miedos comunes como los que podría sufrir cualquier persona. Así mismo, que los films presenten la historia como una leyenda, además de que el propio héroe llegue a negar su procedencia divina, recalca y afianza la tendencia evemerista de estos films

The Legend of Hercules, por su parte, personifica a Hera mediante Alcmena y deja claro que es Zeus quien engendra al joven. Sin embargo, esto no significa que el film se aleje por completo de la idea del evemerismo ya que lo que esta postula hace que los dioses se representen mediante actividades humanas con una vida común: en este caso, la diosa empatiza con la mortal que se encuentra preocupada por la tiranía de su rey. Igualmente, también en este caso Alcides niega en un principio ser hijo de un dios.

Además de este aspecto, es curioso cómo se gestiona en estas cuatro películas la figura de Heracles. Si bien su enfoque es siempre tendente hacia la heroicidad sobrehumana del mismo, no se le presenta en ninguna de ellas como un verdadero semidiós, ni se muestra un posible contacto con el Olimpo. A excepción de la primera película analizada, ningún otro film hace alusión a la apoteosis y deificación de Heracles, tal y como se expone en las fuentes. La fidelidad a las fuentes de Hercules (2005), en relación con el resto de los films que trabajan la figura del héroe heleno en este siglo, la convierte en la única que hace referencia a la glorificación del protagonista. Aunque, evidentemente, no ocurre de la misma forma que en los textos, como ya hemos podido observar, la escena en la que Hércules se introduce en una pira ardiente y es salvado por la intervención de -presuntamente- Zeus produce un cambio en el carácter del personaje pudiéndose pues establecer un paralelismo con la apoteosis que nos exponen los mitógrafos y que le otorgó su inmortalidad.

A diferencia de esta, el resto de las producciones nada tienen que ver con este hecho y siquiera sugieren un posible fin del personaje. Este tipo de películas que están realizadas para el gran público conciben en realidad a Hércules como un héroe al estilo de los "comunes». Este hecho hace que no tenga cabida la muerte o derrota del héroe protagonista ya que el gran público no lo entendería ni aceptaría.

Los últimos tiempos han estado bañados, en cierto modo, de un culto a la imagen personal que ha afectado en todos los ámbitos sociales. El cine es uno de ellos y la figura de Hércules no queda al margen de esta tendencia. Es cierto que desde la antigüedad ya se le describía en los textos como un hombre dotado de notable musculatura y fuerza pero en el caso del cine, y concretamente de estos últimos films, parece que el nombre de Hércules sea exclusivamente sinónimo de un hombre forzudo y de tez morena como si se tratara de un culturista. Lo cierto es que, si algo tienen en común las cuatro películas, es que el protagonista se ciñe estrictamente a estos cánones estéticos y, a pesar de que el carácter que se refleja en los textos pueda quedar en duda, su físico se convierte en algo que no se puede separar del personaje.

Del mismo modo, la historia de Hércules bajo el filtro de un cine comercial ha provocado que en todos los films producidos en este siglo, la historia amorosa esté presente o sea el objetivo del héroe. En el caso de Hercules (2005) y The Legend of Hercules (2014) se hace obvio este hecho ya que la figura femenina como 
esposa o pareja -Deyanira y Hebe respectivamente- se convierte en fundamental para motivar y alentar al protagonista a sortear los obstáculos que se le presentan durante el metraje. Por su parte, en el caso de Hercules (2014) y Hercules Reborn (2014) el aspecto afectivo amoroso se muestra como un objetivo final. Aunque no directamente, los dos films reflejan a un Hércules que después de sus últimas hazañas -las que vemos en el film-y de superar el traumático asesinato inducido de su mujer y sus hijos, pretenden rehacer su vida con la pretensión de crear una familia bajo un nuevo «yo».

Finalmente, como hemos podido comprobar a lo largo de este estudio, cabe señalar que las palabras que dan título a este trabajo definen el uso que el séptimo arte de este siglo hace de los mitos del héroe griego, y en general de la mitología clásica, deformándolos y dándoles una nueva dimensión que los adapta al gusto y la realidad de las sociedades de nuestro tiempo. 


\section{BIBLIOGRAFÍA}

Alonso, Juan J., Mastache, Enrique A. y Alonso, J. (2015), La antigüedad en el cine. Egipto, Grecia y Roma. Madrid, T\&B Editores.

Apolodoro (2013), Biblioteca (Introducción de Javier Arce y traducción y notas de margarita Rodríguez de Sepúlveda). Madrid, Gredos.

Apolonio De Rodas (2011), Argonáuticas (Introducción y traducción de M. Valverde Sánchez). Madrid, Gredos.

Bonnefoy, Y. (dir.) (1997), Diccionario de las mitologías. Volumen III: de la Roma arcaica a los sincretismos tardios. Barcelona, Destino.

Curley, Dan (2018), The Hero in a Thousand Pieces: Antiheroes in Recent Epic Cinema, en Augoustakis, Antony y Raucci, Stacie (2018), Epic héroes on screen. Edinburgh University Press. Edimburgo, 173-190.

Diodoro de Sicilia (1995), Biblioteca Histórica. Libros I-II (Coord. Jesús Lens Tuero). Madrid, Ediciones Clásicas Madrid.

Esquilo, Sófocles, Eurípides (2004), Obras completas (coord. Emilio Crespo). Madrid, Cátedra.

Estrabón (2001), Geografía. Vol. III, Libros VIII-X. (Traducción y notas de García Ramón, J.L.; García Blanco, José y Meana, María José). Madrid, Gredos.

Giordano, Michelle (1998), Giganti buoni. Da Ercole a Piedon (e oltre) il mito dell'uomo forte nel cinema italiano. Roma, Gremese Editore.

Goméz Mesa, Luis (1978), La literatura española en el cine nacional, 1907-1977. Madrid, Filmoteca Nacional.

GonZales, A. (1990), La Fresque et l'Imposture. Le péplum: un genre cinématographique qui se débat entre Histoire et Imaginaire. Annales littéraires de l'Université de Besançon, 429, 133-160.

Grimal, Pierre (2001), Diccionario de mitología griega y romana. Barcelona, Paidós.

Hesíodo (2000), Obras y Fragmentos: Teogonía, Trabajos y días, Escudo, Fragmentos, Certamen (Traducción y notas de Aurelio Pérez Jiménez y Alfonso Martínez Díez). Madrid, Gredos.

Higino (2009), Fábulas (Introducción y traducción de Javier del Hoyo y José Miguel García Ruiz). Madrid, Gredos.

IzzI, M. (2000), Diccionario ilustrado de los monstruos: ángeles, diablos, ogros, dragones, sirenas y otras criaturas del imaginario. Palma de Mallorca, Olañeta.

Ovidio Nasón, P. (1988), Fastos (Introducción, traducción y notas por Bartolomé Segura Ramos). Madrid, Gredos.

Ovidio Nasón, P. (2015), Metamorfosis (Introducción y notas de Antonio Ramírez de Verger y traducción de Antonio Ramírez de Verger y Fernando Navarro Antolín). Madrid, Alianza Editorial.

Pausanias (2000), Descripción de Grecia: Ática y Élide. Libros I, V y VI (Introducción, traducción y notas de Camino Azcona García). Madrid, Alianza.

Píndaro (2008), Obra completa (Ed. Emilio Suarez de la Torre). Madrid, Cátedra.

Ramírez Guedes, E. (2017), Una aproximación a la guerra de Troya y sus fuentes preilíacas. Latente: revista de historia y estética del audiovisual, I5, I55-200.

Ruiz de Elvira, A. (1982), Mitología Clásica. Madrid, Gredos. 
Salzman-Mitchell, P. y Alvares, J. (2018), Classical Myth and Film in the New Millemium. New York, Oxford University Press.

Tito Livio (2006), Historia de Roma desde su fundación (Introducción por Ángel Sierra). Madrid, Gredos.

Virgilio (2010), Eneida (Introducción de José Luis Vidal y traducción de Javier de Echave-Sustaeta). Madrid, Gredos. 


\title{
LAZZARO FELICE, EL HÉROE SANTO DE ALICE ROHRWACHER
}

\author{
Teresa Rodríguez Hage \\ Universidad de La Laguna
}

\section{RESUMEN}

Partiendo de la premisa de que Lazzaro Felice (2018), de la cineasta italiana Alice Rohrwacher nace de una visión del mundo que hunde sus raíces en la tradición cristiana y, por tanto, se comprende mejor desde la perspectiva religiosa, analizaremos los diferentes elementos narrativos y estéticos del film, centrándonos en la creación del personaje central, Lazzaro, que, con una poderosa carga espiritual de resonancias cristológicas, es la clave esencial para la interpretación del film. Sin embargo, la lectura religiosa no se agota en su figura, por lo que identificaremos también las numerosas referencias cristianas (iconográficas, sonoras y narrativas) reconocibles en la puesta en escena y nos detendremos en algunos fragmentos del film que revelan cómo las elecciones formales de la directora traducen al lenguaje visual y sonoro la presencia de lo sagrado en la vida cotidiana.

Palabras Clave: Lazzaro Felice, Alice Rohrwacher, cine religioso, cine y religión, cine de mujeres, cine italiano, cine contemporáneo.

\section{LAZZARO FELICE, THE ALICE ROHRWACHER'S HOLY HERO}

\section{Abstract}

Starting from the premise that Lazzaro Felice (2018) by the Italian filmmaker Alice Rohrwacher is born from a vision of the world that has its roots in the Christian tradition and, therefore, is better understood from a religious perspective, we will study the different narrative and aesthetic aspects of the film, focusing on the creation of the central character, Lazarus, who, with a powerful spiritual charge of Christological resonances, is the essential key to the interpretation of the film. However, the religious approach is not limited to his figure, so we will also identify the numerous Christian references (iconographic, sound and narrative) recognizable in the staging and finally, we will discover some fragments of the film which reveals how, the director's formal choices seek to translate into visual and sound language the presence of the sacred in everyday life.

Keywords: Lazzaro Felice, Alice Rohrwacher, religious cinema, Religion in film, female filmmakers, women directors, contemporary films. 
Erial de perplejidad, en los ardientes laberintos; perdidos, entre brillantes estrellas, en esta tediosísima ceniza, ;perdidos! Recordando sobrecogidos, buscamos el gran lenguaje olvidado, el perdido sendero que conduce al cielo, una piedra, una hoja, una puerta ignota. ¿Dónde? ¿Cuándo?

El ángel que nos mira, Thomas Wolfe

De cierto os digo, si no os volvéis y os hacéis como niños, no entraréis en el reino de los cielos.

Mateo 18, 3

\section{CINE Y CRISTIANISMO}

El diálogo entre cine y religión se ha venido entablando desde la aparición del cinematógrafo, que rápidamente se convirtió en uno de los medios de expresión artística más valiosos tanto para la representación naturalista de temas bíblicos como para la plasmación de ideas más espirituales o metafísicas sobre la búsqueda de lo trascendente. Las aproximaciones al fenómeno religioso que ha dado la historia del cine suelen clasificarse en las categorías clásicas de cine comercial y cine de autor o independiente: las propuestas más comerciales basadas bien en las narraciones del Antiguo y Nuevo Testamento (como ejemplo, las cuantiosas versiones sobre la figura de Jesús de Nazaret), o bien las inspiradas en las biografías de personajes del mundo religioso: santos, sacerdotes, predicadores, misioneros, papas, etc., con claro enfoque en las audiencias y escaso interés en plantear cuestiones espirituales. Y, por otro lado, las propuestas más personales de cineastas que quieren transmitir su visión del mundo y su búsqueda de sentido en lo trascendente a través de formulaciones estéticas menos ortodoxas, directores cuya indagación en "lo sagrado" remite a experiencias interiores que expresan con un lenguaje más abstracto, simbólico o metafórico, hablamos de la obra de cineastas como Tarkovski, Dreyer, Bresson, Bergman, Buñuel, Fellini o, más recientemente, Malick. En este espacio más hondamente religioso ubicamos la obra de la italiana Alice Rohrwacher.

Nuestro trabajo plantea que la película Lazzaro Felice (2018), de la cineasta Alice Rohrwacher, nace de una visión del mundo de raíces cristianas y, por tanto, se comprende mejor desde la perspectiva religiosa. Partiendo de esta premisa, analizaremos los diferentes elementos narrativos y estéticos del film, centrándonos en la creación del personaje central, Lazzaro, que, con una poderosa carga espiritual de resonancias cristológicas, es la clave esencial para la interpretación del film. Sin embargo, la lectura religiosa no se agota en su figura, por lo que identificaremos también las numerosas referencias cristianas (iconográficas, sonoras y narrativas) reconocibles en la puesta en escena y, finalmente, nos detendremos en algunos fragmentos del film que revelan cómo las elecciones formales de la directora traducen al lenguaje visual y sonoro la presencia de lo sagrado en lo cotidiano, lo cual expresa a través de una estética de enorme carga poética que aparece de forma súbita en varios momentos de la película y que algunos autores han querido asociar al «realismo mágico». Sin embargo, este estilo literario cuya finalidad es ofrecer, a través de un exuberante lenguaje, un mundo desbordante de fantasía y magia poco tiene 


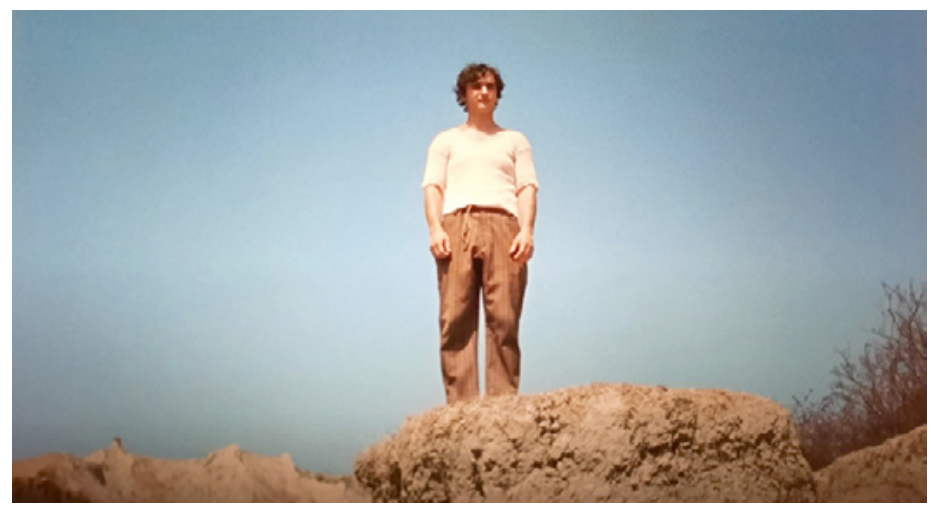

Fig. 1. Lazzaro en un plano del film que recuerda por su angulación y composición a otro similar del personaje de Johannes en el film Ordet (1955), de C.T. Dreyer. Fotograma de Lazzaro Felice.

que ver con las búsquedas espirituales que plantea la película de Rohrwacher, cuyo estilo prescinde totalmente de lo espectacular y de lo fantástico. Con una mirada honesta y clara que se expresa a través de un estilo realista y lírico a un tiempo, dentro de la tradición de los grandes maestros del cine italiano, Rohrwacher logra establecer una poderosa conexión espiritual con el espectador en una película que se revela como una apasionada búsqueda de Dios en un mundo que se desmorona.

\section{EL CARTEL DE LAZZARO FELICE}

El cartel de Lazzaro Felice ofrece una reinterpretación de la misteriosa pintura Gilles (1718 o 1721), de Watteau, también llamada Pierrot (personaje de la Comedia Italiana del Arte). La elección de esta obra del rococó francés como inspiración del póster de la película es toda una declaración de intenciones. Lo analizamos en detalle: Lazzaro ocupa en el cartel el mismo lugar central que Gilles en la obra pictórica, presenta la misma expresión triste y melancólica, idéntica atmósfera poética e irreal lo rodea. Al paisaje de fondo en la pintura, el cartel del film agrega la ciudad, escenario de la segunda parte de la cinta. Se han suprimido los comediantes de la obra pictórica que se encuentran a la espalda de Gilles y el asno ha sido sustituido por el lobo (personaje simbólico del film). Gilles representa a uno de los zanni (sirviente), personajes que en la comedia italiana conducían la obra. Lazzaro es el sirviente en la aldea de Inviolata y también constituye el eje de la narración en el film. La elección de esta obra no es casual, ya que a pesar de representar a un personaje de la comedia italiana, este Pierrot no es el alegre y divertido payaso que ha sido retratado por otros artistas. Rohrwacher ha elegido al melancólico Gilles de Watteau, a quien el prestigioso crítico de arte László Földényi (2004) compara con Cristo: «Da la impresión de que Watteau lo pintó de entrada con la intención de transmitir lo invisible, de hacer aparecer, pictóricamente, lo que no puede pintarse... 


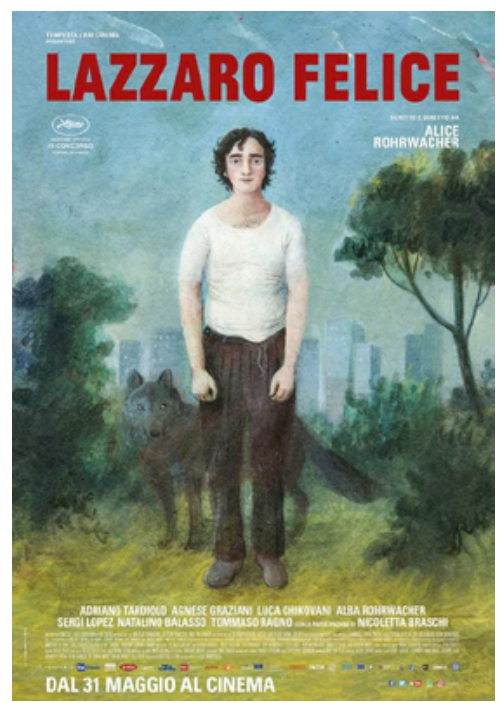

Fig. 2. Cartel de Lazzaro Felice. Dosier prensa Festival de Cannes, 2018.

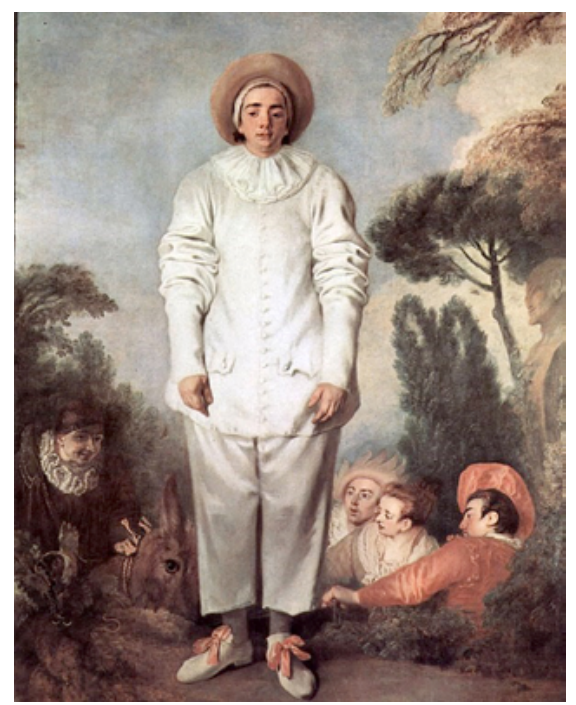

Fig. 3. Gilles (1721), A. Watteau. Obras maestras de la pintura, Madrid, Planeta, 1983.

Gilles es al mismo tiempo figurante y protagonista de lo invisible. Lo encarna y lo padece (paralelismo con Cristo)».

\section{INVIOLATA, LA ALDEA DONDE HABITA DIOS}

En su primera película, Corpo celeste (2011), la directora italiana ya había hecho una profunda indagación espiritual a través de su protagonista, Marta, una adolescente de 13 años, que ante la inminencia del sacramento de la confirmación se enfrenta a una demoledora búsqueda interior. Sobre esta primera exploración del mundo religioso la propia Rohrwacher decía: «El catolicismo en mis películas es una presencia constante, funciona más como una conciencia. En Corpo celeste es muy fuerte su presencia porque en Italia siempre ha sido clara la tensión que existe entre el deseo de una comunidad por unirse alrededor de la religión y la imposibilidad de lograrlo» (Atehortúa, 2021).

Su segundo largometraje, Le meraviglie (2014), que obtuvo el Gran Premio del Jurado en el Festival de Cannes de ese año, se centra en la historia de un matrimonio con cuatro hijas que se dedican a la explotación apícola en una granja de la Toscana, lo que le sirve para seguir ahondando en los conflictos familiares, las complicaciones de la adolescencia, las contradicciones entre tradición y modernidad y entre la vida rural y urbana, temas que también aborda en Lazzaro Felice (2018), su película más premiada. El año de su estreno consigue varios galardones: Mejor 


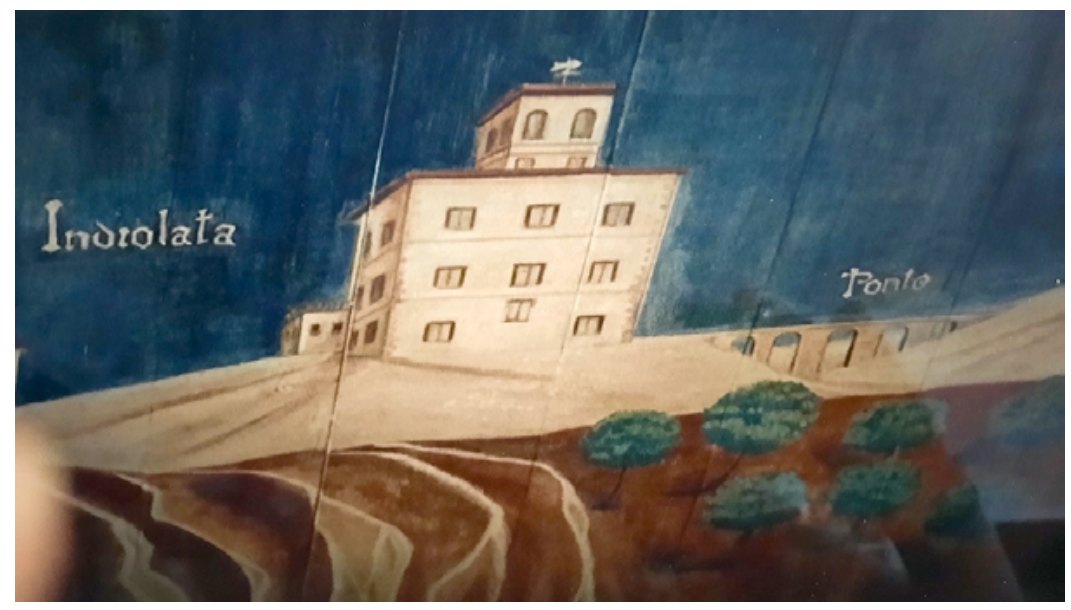

Fig. 4. Fotograma de la película que muestra un antiguo cuadro de Inviolata con el puente (aún en pie) que unía la aldea a la civilización.

Guion en el Festival de Cannes, Premio Cummings a la Mejor Película en el Festival Internacional de Cine de Jerusalén, Premio Especial del Jurado en el Festival de Sitges, Mejor Película Extranjera en el National Board of Review y numerosas nominaciones en distintos festivales internacionales de cine.

La película narra la historia de Lazzaro (interpretado por Adriano Tardiolo), un joven campesino de extrema bondad que vive en una aldea interior de Italia llamada Inviolata, un lugar aislado de la civilización donde los campesinos trabajan para la marquesa Alfonsina de Luna (la actriz Nicoletta Braschi) en un sistema de aparcería ya abolido que ésta oculta a sus jornaleros, quienes la consideran propietaria incluso de sus propias vidas. Los campesinos son vilmente explotados por la marquesa y al mismo tiempo ellos explotan a Lazzaro, aprovechándose de su candorosa ingenuidad. Un verano la marquesa trae consigo a su hijo Tancredi (que interpreta Luca Chikovani), un joven imaginativo y rebelde que se aburre en el hogar familiar. En la hacienda conoce al inocente Lazzaro y nace entre ellos una bonita amistad adolescente. «Una amistad tan preciosa», revela la directora, «que le permitirá a Lazzaro atravesar el tiempo y llegar al mundo moderno en busca de su amigo» (Tempesta Film, 2018).

Inviolata (la aldea «intocada») simboliza, en cierto modo, un paraíso perdido, la forma de vida campesina, hoy casi desaparecida en Italia. De ahí que se nos muestra como un lugar aislado del mundo, no sólo espacialmente (ya que el puente que lo unía a la civilización está derribado), sino temporalmente: los campesinos parecen habitar en una edad perdida, lejana, viviendo al ritmo de la siembra y la cosecha.

Desde el punto de vista técnico, la película se filma en $16 \mathrm{~mm}$, lo que aporta ciertas imperfecciones expresivas que transmiten mayor naturalidad a las imágenes. 


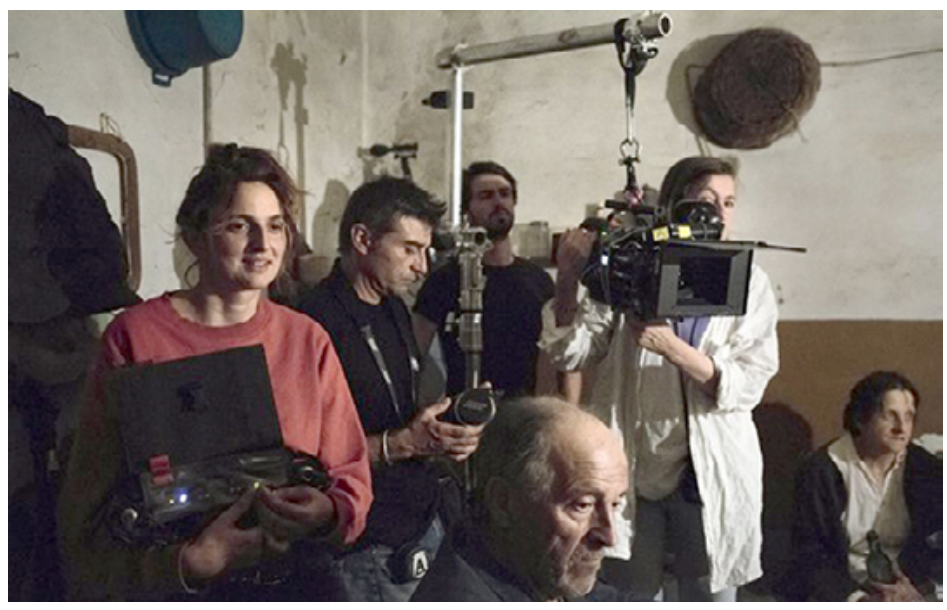

Fig. 5. Alice Rohrwacher en un momento del rodaje.

A este respecto se expresa también la directora de fotografía de la película, Hélène Louvart:

Este medio aporta algo orgánico, artesanal, que corresponde a una forma de ver el mundo un poco diferente. El renderizado del Super 16 desprende una forma de poesía, de «fiebre de la imagen» y nos gusta la sensación de estar siempre un poco sorprendidas por el renderizado de las imágenes, a veces demasiado oscuro o demasiado brillante, poco nítido o granulado. Un poco como si no domináramos por completo esta herramienta, pero las imperfecciones de este formato finalmente le darán un significado visual a la película, un deseo que no busca controlarlo todo de manera sistemática (AFS, 2018).

Por su parte, el guion de la película encuentra su origen en un hecho real que Alice Rohrwacher había leído en la prensa italiana:

Esta [película] también está relacionada con el hecho de que leí un artículo de un periódico cuando era bastante joven que decía que había una marquesa que había mantenido a algunos de sus aparceros como aparceros sin informarles, aprovechando lo ingenuos que eran. Entonces, cuando finalmente me ofrecieron la oportunidad de estar en el programa del Cineasta en Residencia del Festival de Cine de Nueva York, tuve la distancia suficiente para mirar todo eso y escribir sobre ello (Saito, 2018).

«¿No tienes miedo de que descubran la verdad?», pregunta Tancredi a su madre en un momento de la película. "Los seres humanos son como animales. $\mathrm{Si}$ los liberas, serán conscientes de su condición de esclavos y se sumirán en la miseria. Ahora sufren también pero no lo saben", responde la marquesa sin el menor escrúpulo. Luego, observando desde la ventana a Lazzaro, añade: «Mira, ¿lo ves?, yo me 


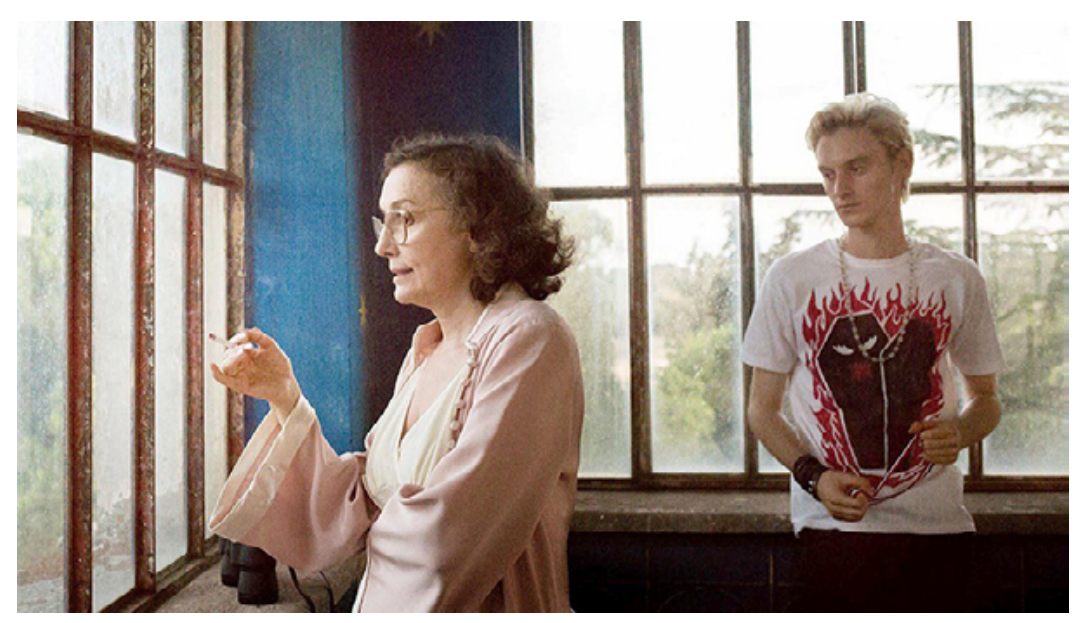

Fig. 6. La marquesa de Luna y su hijo Tancredi hablan sobre la explotación humana en una escena del film. Fotograma de la película.

aprovecho de ellos y ellos se aprovechan de él. Es una cadena, no se puede parar». «A lo mejor él no se aprovecha de nadie», dice su hijo, que mira con simpatía a Lazzaro.

La historia se estructura en dos partes: la primera ubicada en un espacio rural en la década de los ochenta del siglo pasado y, tras un suceso inesperado que revela la realidad de su condición a los aparceros, la acción se traslada a la periferia urbana unos veinte años después. Saltamos en un instante de la Italia rural a la Italia urbana, la explotación de la aristocracia terrateniente de la sociedad preindustrial ha sido sustituida por la de los poderes financieros del capitalismo. Las víctimas continúan siendo los campesinos, reconvertidos ahora en vagabundos del extrarradio urbano que malviven a base de pequeńos robos sumidos en la miseria, como había vaticinado, no sin cierta ironía del guion, la marquesa. Su situación no ha mejorado, han pasado de la condición de "esclavos» de la nobleza campesina a la de «esclavos» de la sociedad del progreso. Sus creencias religiosas han sido reemplazadas por el culto a la televisión y a la comida basura. La película muestra la miseria material y moral de los personajes, el ser humano no ha evolucionado en la era del capitalismo, se ha vuelto más pícaro y se ve obligado a delinquir para poder sobrevivir. Sólo Lazzaro, inocente y atemporal, permanece ajeno al mundo miserable que le rodea. Lazzaro constituye el nexo entre pasado y presente, entre lo rural y lo urbano, entre los nobles y los campesinos, entre la alegría estival y la crudeza del invierno. Cuando el mundo de los personajes se vuelve frío y oscuro, cuando el universo idílico de Inviolata se derrumba, la película nos muestra un resquicio de esperanza. La inocencia de Lazzaro revela que hay algo más allá del dolor y del esfuerzo humanos, algo que nos viene dado y que sólo se puede percibir espiritualmente.

«Inicié la escritura pensando el contexto, el momento apocalíptico, la crítica que tenía que llevar la historia. Y posteriormente entendí que el protagonista tenía que 


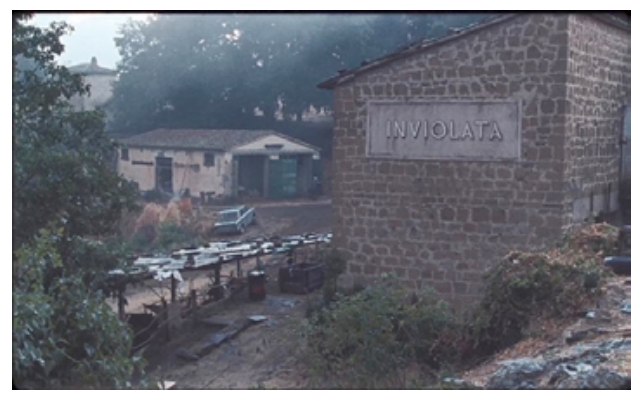

Fig. 7. La hacienda de Inviolata donde viven hacinados los campesinos. Fotograma del film.

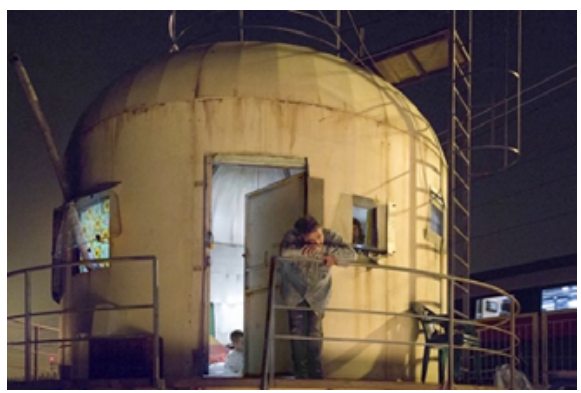

Fig. 8. El hogar en el que habitan los personajes en la ciudad es un viejo y abandonado tanque industrial. Fotograma del film.

ser un hombre bueno, este Lazzaro que dedica mucho tiempo a ayudar a los demás, a una bonhomía que atraviesa el tiempo». Sobre la explotación del ser humano por el ser humano, la directora lo tiene claro: «Es una historia clásica, ¿verdad? Y el mundo cambia, se transforma y el ser humano sigue idéntico» (entrevista a Rohrwacher en Belinchón, 2018).

Por otro lado, la directora italiana refiere la devastación humana que supuso en su país el éxodo casi forzoso del campo a la ciudad de miles de campesinos.

La tragedia que ha devastado a mi país, a saber, el paso de una Edad Media histórica a una edad media humana: el final de la civilización rural, la migración a los límites de la ciudad de miles de personas que no conocían nada de la modernidad (Tempestá, 2018).

La película es susceptible de diferentes e interesantes lecturas: histórico-política (Andi, 2019), sociológica (Guardiola, 2019), filosófica (Cavalcanti, 2020), ecológica (Di Bianco, 2020), etc., que vendrían determinadas por sus propias dicotomías argumentales: pasado y presente, vida rural y urbana, feudalismo y capitalismo, lucha de clases y también por las muchas confluencias temáticas o subtextos: las injusticias sociales, la alegría de la amistad adolescente, el núcleo familiar y la pertenencia a la comunidad, el éxodo del campo a la ciudad, el problema de la inmigración, la explotación humana, etc., pero además de la evidente denuncia sociopolítica que hace Rohrwacher y de su visión más bien pesimista de la historia y de la condición humana (muy cercana a la de Buñuel, especialmente la que mostró en su tratamiento de los mendigos en Viridiana), Lazzaro Felice reclama una lectura religiosa. Una película que sugiere que la única salida a ese mundo agotado, miserable e injusto que se pone ante nuestros ojos se encuentra en "mirar» de una manera pura como hace Lazzaro; una película que establece correlaciones entre el mundo exterior e interior del ser humano, entre lo racional y lo espiritual, lo visible y lo invisible, que evoca el «misterio», el mundo de lo sublime y lo inexplicable; una película que se pregunta sobre el sentido del sufrimiento; una película, en definitiva, que logra 


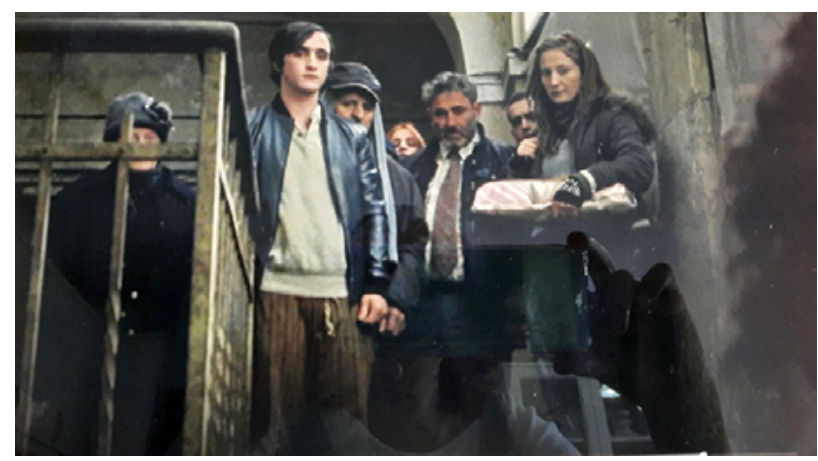

Fig. 9. En la ciudad, los personajes acuden a la cita con Tancredi. En primer plano los actores Adriano Tardiolo (Lazzaro), Sergi López (Ultimo) y Alba Rohrwacher (Antonia adulta).

Fotograma de la película.

alcanzar zonas profundas del alma humana es, no cabe duda, una película religiosa. Una película inspirada, según su autora, en una religión que une a la humanidad espiritualmente, no en una religión oficial:

Creo que si un santo apareciera hoy con una llamada a otra forma de existir, si apareciera en nuestras vidas modernas, tal vez ni siquiera lo reconoceríamos o tal vez nos libraríamos de él, sin pensarlo. Estamos hablando aquí de una religión de la humanidad, no de una religión oficial bien administrada con sus vestiduras deslumbrantes y sus reglas semanales (Tempesta Film, 2018).

Lazzaro Felice propone pues otra forma de existir, otra forma de «mirar el mundo», propone abiertamente que tomemos a Lazzaro como modelo y Lazzaro, que encarna la bondad suprema, remite de manera directa a la figura de Cristo, como ya lo había hecho en la literatura rusa otro inolvidable personaje, con quien Lazzaro tiene más de una conexión, el príncipe Mishkin de la novela El idiota (1868) de Dostoievski. Lazzaro y el inocente Mishkin son personajes a través de los cuales se nos invita a emprender un nuevo camino, a renovarnos, a inventar una nueva humanidad. Lazzaro Felice es una profunda reflexión sobre la sociedad, sobre el ser humano en la historia y sobre su relación con lo sagrado. La imagen luminosa del protagonista atenúa, en cierto modo, la degradación humana de sus compañeros de viaje mirados con crudo realismo, pero también con ternura por la directora italiana. A este respecto es interesante señalar, con Greeley (1988), que la teología católica, al contrario de la opinión generalizada, ve la naturaleza humana como «desvalida» más que como "pecadora», así ve también Rohrwacher a sus personajes, a esos pobres campesinos arrojados casi por la fuerza a la metrópoli donde intentan sobrevivir como desahuciados en un desolador paisaje material y humano.

Lazzaro es también, en cierto modo, un personaje desvalido, lo es para nosotros como espectadores pero él no se siente así en modo alguno. Lazzaro es 


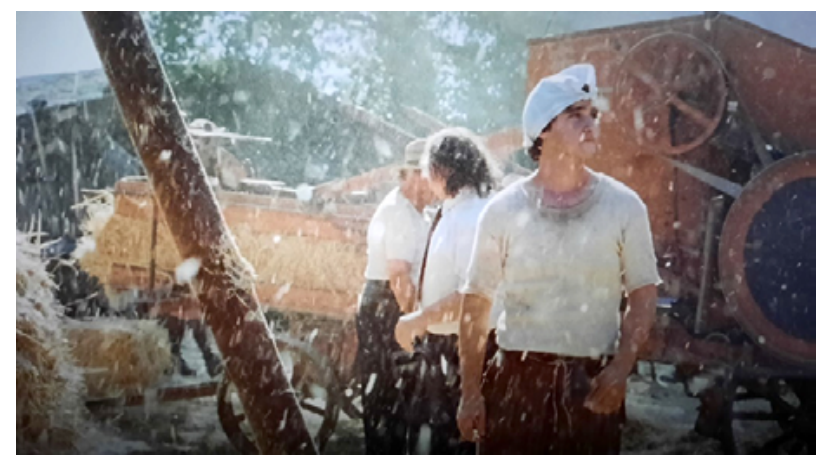

Fig. 10. Lazzaro en un momento de la cosecha. Fotograma de la película.

feliz porque su inocencia es como la de un niño, no tiene conciencia de su felicidad porque es su propia naturaleza, la fuerza del personaje reside en la pureza con que mira al mundo que le rodea. En este sentido, Lazzaro ha sido creado, afirma la directora, para "ser mirado, es difícil que podamos identificarnos con un santo [...] Una película en la que, si se sufre, no es porque se sea el protagonista, sino porque lo estás mirando" (Atehortúa, 2021). Lazzaro es diferente a los demás, es un personaje contrapuesto a los otros porque es un ser extraordinariamente ingenuo, sin malicia, un ser puro, espiritual. Los campesinos se aprovechan de esa ingenuidad, es su pretexto para explotarlo. En Inviolata es el sirviente de todos, le exigen que lleve a cabo todas las tareas: sembrar, recolectar, cargar y descargar la cosecha, trasladar las mercancías, los enseres, ocuparse de las gallinas, de las ovejas, traer y llevar a la abuela... pero a Lazzaro no le importa, no se cansa, no protesta, es «manso y humilde de corazón» como Jesús.

\section{DEL RELATO PASTORIL A LA LEYENDA DEL LOBO}

El personaje de Lazzaro aparece como imagen inicial del largometraje, en la oscuridad de la noche. Le preceden los títulos de crédito sobre fondo negro, se escucha el canto de los grillos y voces y risas de los campesinos, luego se oye: «Lazzaro", y los créditos abren a un plano general donde vemos al muchacho a las puertas de un granero, sujeta una zampogna ${ }^{1}$. "¿Ya estás mirando al infinito?», le dice otro personaje que se le acerca, "Vamos, nos están esperando, arréglate el pelo» y dócilmente el joven se deja peinar. La siguiente escena traslada la acción de nuevo a la oscuridad, se oye el llanto de un bebé seguido por la voz de una joven que pide

${ }^{1}$ Gaita típica de la música folclórica del sur de Italia, cuya tradición se remonta a los pueblos pastores de las regiones montańosas. Su uso se relaciona con la Navidad. 


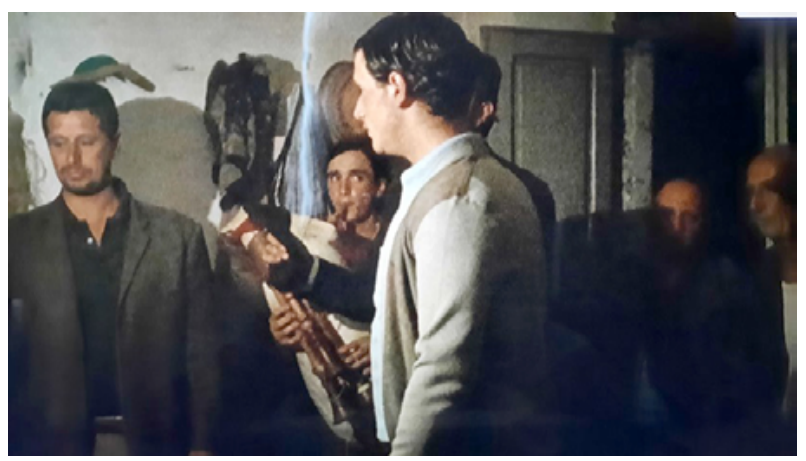

Fig. 11. Los campesinos celebran la fiesta de compromiso. Lazzaro toca la zampogna. Fotograma del film.

un bombillo (vemos que éste se pasa de una a otra estancia, sólo hay uno para toda la casa, reflejo de la pobreza extrema de sus moradores). Se ilumina por fin una habitación y vemos a un grupo de jóvenes como ángeles con sus vestidos claros, su alegría y una luz deslumbrante que dibuja sus figuras y movimientos en el encuadre. Bromean y ríen con la joven enamorada, Mariagrazia (vestida de azul como se suele representar iconográficamente a la Virgen María), a quien destina su canción Giuseppe (José) bajo la ventana. En el exterior, los cantores ofrecen una serenata nocturna, Lazzaro toca la zampogna. El grupo entra en la casa y los labriegos ofrecen lo poco que tienen: un vaso de Marsala y una lata de anchoas que se reparte para todos. Los músicos continúan con la canción, la cámara recorre la modestísima estancia y nos va mostrando los rostros envejecidos de todos los campesinos que comparten la misma morada, austera y humilde. Las imágenes transmiten un realismo casi documental. Y en el recorrido, la cámara da un primer plano a Lazzaro justo cuando Giuseppe entona el verso: «haces a los ángeles bajar del Paraíso». Todos beben del vaso de vino, Lazzaro se coloca el último y cuando llega a él, ya no queda vino. «No importa», dice gentil.

La película se inicia como vemos con una escena nocturna. Rohrwacher explica en una entrevista concedida a Jerónimo Atehortúa (2021) su preferencia por iniciar la narración en la oscuridad:

Para mí, empezar en la noche es poner a los espectadores en un lugar en el que deben usar su imaginación, dejándose afectar por los sonidos, pues aún no saben dónde están, aún están un poco perdidos. De esta manera, nuestra relación empieza mediada por la imaginación. Esto parte del juego que me interesa en una película como espectadora, no solo como directora. También esto es reflejo de mi fascinación por el juego entre la luz y la oscuridad, por las sombras.

A nivel estético, la escena se crea, como dijimos, en clave documental: los aparceros no son actores profesionales sino campesinos de la zona; la cámara muestra sus rostros duros, secos, curtidos por el trabajo; una cámara objetiva, enunciativa, 


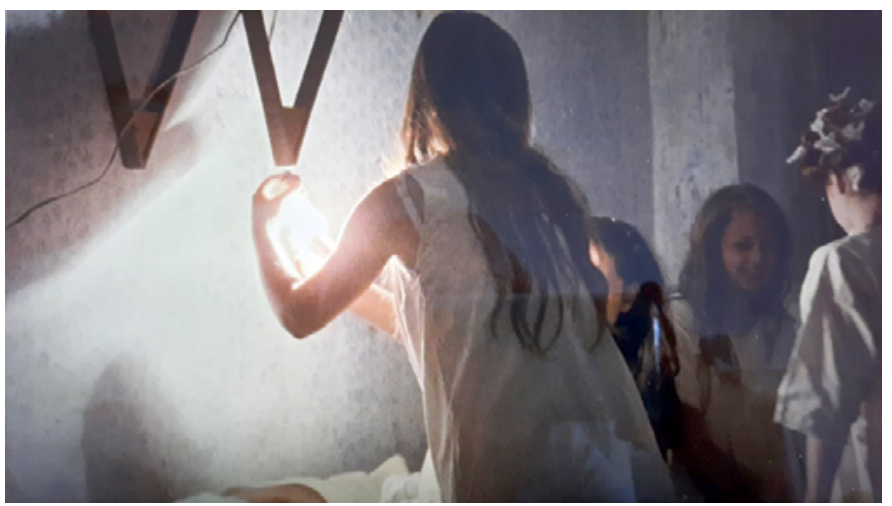

Fig. 12. Las jóvenes de Inviolata encienden la luz en la habitación al escuchar a los músicos bajo la ventana. Fotograma de la película.

que, de vez en cuando, se detiene para mostrar un encuadre de Lazzaro, o de Antonia (la protagonista femenina, interpretada como adolescente por la actriz Agnese Graziani), que le mira, quizá intuye en él algo que los demás no perciben. Luego Giuseppe anuncia que él y Mariagrazia se quieren ir a la ciudad a probar fortuna. La escena se corta con la inquietante aparición de una gallina (anuncio de la amenaza del lobo) a la que la cámara le dedica algunos planos (al más puro estilo Buñuel). A continuación se ordena a Lazzaro que la devuelva al gallinero.

En esta primera secuencia del film, construida en cuatro escenas a modo de prólogo, encontramos varios elementos que remiten a la tradición cristiana del belén ${ }^{2}$ : un bebé que llora, las figuras de María y José reflejadas en los nombres de los jóvenes enamorados Giuseppe y Mariagrazia, iluminados siempre por la luz de la estancia, los alegres ángeles en la ventana, los pastores que cantan al ritmo de la zampogna. En definitiva, la humilde morada de Jesús de Nazaret, que, desde el punto de vista histórico, fue un profeta judío campesino. Por otra parte, aparece también en la referencia al lobo que caza a las gallinas, la primera evocación a la leyenda de san Francisco de Asís y el lobo de Gubbio ${ }^{3}$, que tiene una presencia constante en la película. Cuando Lazzaro llega al gallinero, Carletto, otro labriego que quiere unirse a la fiesta de la casa, le pide que lo sustituya en la guardia del lobo. Lazzaro accede apaciblemente. Se queda solo, más tarde llama a Carletto, que no responde. Entonces se sienta, mira al cielo y dice: «no me oye». Contraplano de la luna (Lazzaro habla a la «hermana luna»). Funde a negro y aparecen los créditos del título de

2 Según la tradición franciscana, el primer belén o pesebre de la historia fue obra de san Francisco de Asís en la localidad de Greccio (Italia) en 1223 (Relato de San Buenaventura, LM, 10, 7).

${ }^{3}$ La leyenda aparece narrada en el anónimo del siglo xiv Las florecillas de San Francisco (I fioretti di San Francesco) en el capítulo xxi: «Cómo San Francisco amansó, por virtud divina, a un lobo ferocísimo». 


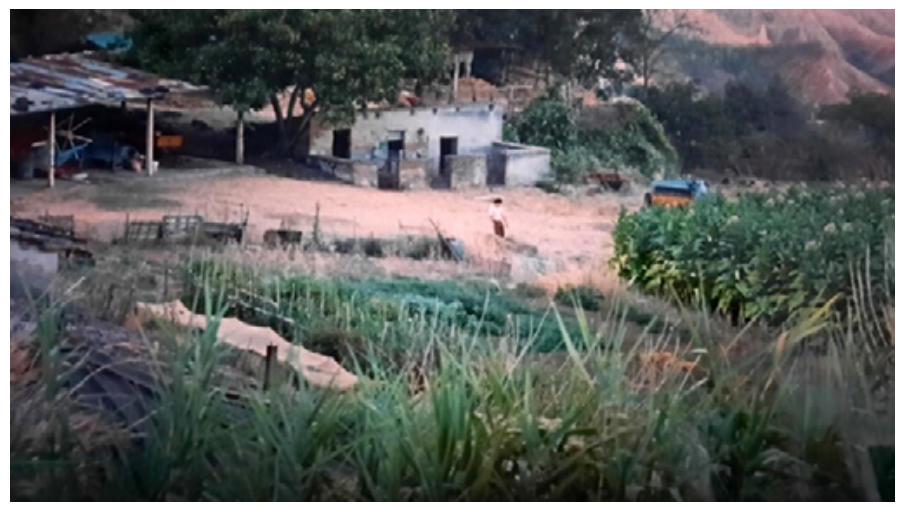

Fig. 13. Lazzaro recoge la cosecha en la hacienda. Fotograma del film.

la película. Este mundo rural de la primera parte de Lazzaro Felice se recreó recuperando una zona agrícola en un lugar cerca de Vetriolo, lo relata Emita Frigato, la directora de escenografía:

En cooperación con los pocos habitantes de Vetriolo, cultivaron tabaco, mes tras mes. Comenzaron un huerto y trajeron gallinas, patos, pavos y otros animales. Después de encontrar una trilladora de la década de 1950 en el granero de un agroturismo local, la restauraron y encontraron agricultores que sabían cómo usarla. Trajeron campesinos de los alrededores de Viterbo para repoblar la Inviolata. «La gente local, algunas de las cuarenta personas que una vez vivieron allí, se emocionó al ver que el lugar volvió a la vida» (Bianco, 2020).

Tras las escenas iniciales de la historia, que comienzan como un apacible relato pastoril, descubrimos que en Inviolata la vida no es tan idílica como parece. A la mañana siguiente, mientras los campesinos hacen la cosecha en la plantación de tabaco, llega Nicola, el administrador de la marquesa, acompañado de un sacerdote que viene a bendecir la nueva cosechadora. Como ha apuntado Hugo Cavalcanti (2020), la Iglesia católica es visiblemente enjuiciada en el film. Efectivamente, el personaje del sacerdote, con su presencia en Inviolata junto al capataz, indica que es conocedor de la explotación que sufren los campesinos y, en consecuencia, la acepta y la consiente. Por su parte, Nicola se nos muestra como un ser despreciable, mientras pide a Lazzaro que descargue la mercancía que ha traído, dice a una campesina, guiñándole el ojo, que el bebé que lleva en los brazos se parece a él (insinúa que es un hijo ilegítimo suyo), después ofrece caramelos a los niños en actitud paternalista y al entrar a la casa, bromea amigablemente con los aparceros para inmediatamente escamotearles sus ganancias: suma los productos de la cosecha pero descuenta a los campesinos lo que les ha traído en la camioneta: «Si a eso le resto el rollo de alambre, la gasolina, las anchoas y los enseres domésticos, pues sale... Pero ¿y los capones?», pregunta. "Los devoró el lobo», responde un campesino. "Con lobo o sin lobo, los capones ya no están. Así que los añado a las deudas. Y con esto, también este mes 


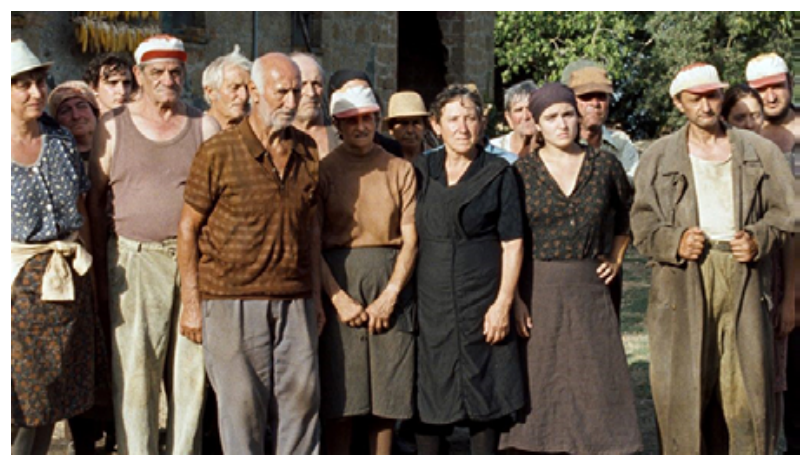

Fig. 14. Los campesinos miran furiosos a Nicola cuando grita que el niño le ha robado el espejo de la moto. Fotograma del film.

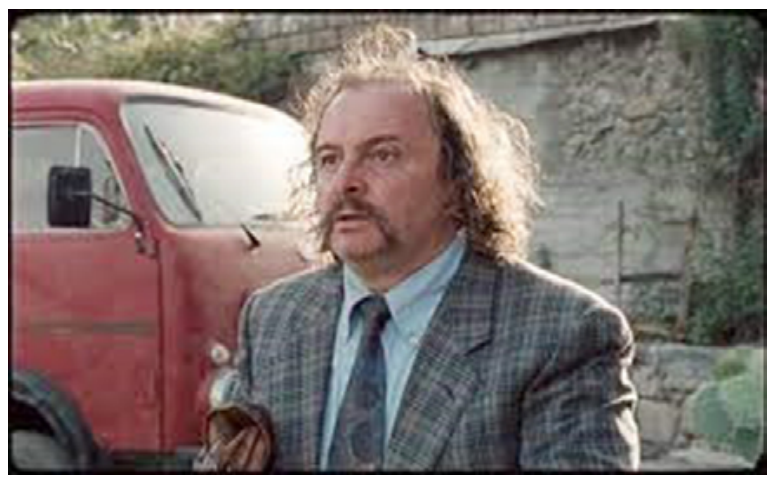

Fig. 15. Nicola, el administrador de la marquesa, mira asustado a los campesinos. Fotograma del film.

sube la deuda», les dice sin el menor reparo. "Vaya, otro mes que hemos trabajado para nada», responde una mujer. «Deberíamos partirle las piernas».

La irrupción en escena del sacerdote gritando que ocurre algo grave los lleva a todos al exterior y vemos a Giuseppe y Mariagrazia subidos a la camioneta con la intención de irse a la ciudad, Nicola se enfada y les dice que no pueden, que tienen que pedir permiso a la marquesa. Un niño sube a su moto jugando, Nicola grita que le ha robado el espejo. Y justamente, como en un juego de espejos, la escena cambia de registro en ese instante: desaparece el sonido natural en la banda sonora y es reemplazado por el de un viento furioso, vemos un plano de los campesinos, que miran firmes y desafiantes al capataz, y otro del capaz asustado. Esta transformación de los recursos expresivos muestra el miedo de Nicola y la furia de los campesinos. El plano del espejo que sostiene el niño en la mano da paso a una inversión de la realidad para revelar el inconsciente de los personajes. El capataz huye a toda prisa y los niños le siguen corriendo tras la moto. Luego la cámara muestra a Lazzaro en 


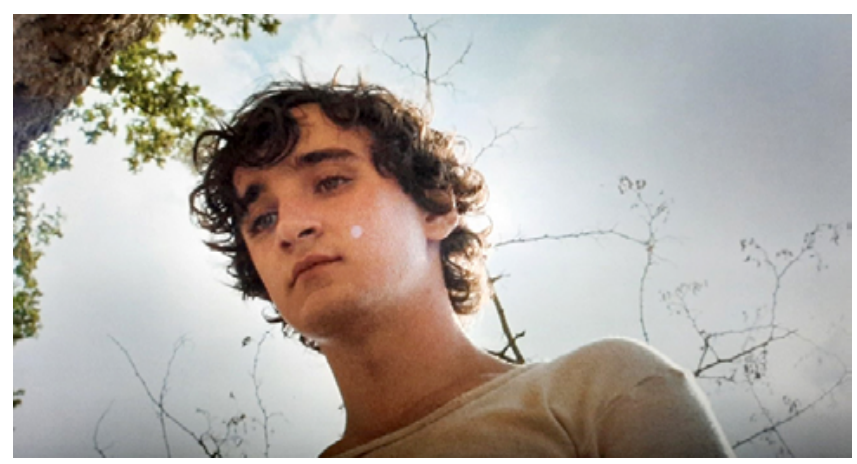

Fig. 16. Lazzaro, un espíritu puro que evoca la figura de Jesús de Nazaret. Fotograma del film.

la camioneta, que va delante de Nicola con el producto de la cosecha, el sonido del viento se mezcla ahora con el aullido del lobo y, finalmente, vuelve el sonido natural de la escena. Ésta es la primera vez que la película nos muestra esa estética personal de Rohrwacher consistente en evocar las emociones humanas de sus personajes a través de la subversión del lenguaje fílmico. Después de este momento poético, la cámara sigue a la camioneta, que se dirige a la casa de la marquesa para descargar la cosecha. Mientras Lazzaro hace el trabajo, el sacerdote lo observa impasible sin prestarle la menor ayuda. Tampoco lo hace Nicola, que lo invita, con total desvergüenza, a volver caminando a la aldea.

\section{LAZZARO, EL HÉROE SANTO DE ALICE ROHRWACHER}

Rohrwacher nos presenta desde el inicio de Lazzaro Felice el retrato de un "siervo de Dios», el retrato de un santo de nuestro tiempo. Para la caracterización de su héroe, la directora toma referencias y elementos del cristianismo. Lazzaro, como habíamos dicho, es símbolo de la bondad suprema y, por tanto, representa la figura de Jesús. Su alma pura conecta con Dios. Es un ser espiritual rodeado de amenazantes lobos que se aprovechan de su inocencia (Mt 10, 16: Yo os envío como ovejas en medio de lobos). Los lobos para Lazzaro son los propios personajes que le rodean, sin embargo, la figura del lobo (alusión franciscana), presentada desde el inicio del film como un peligro para los campesinos, no lo es para el protagonista, como irá revelando la trama.

La caracterización de Lazzaro remite a la figura de san Francisco de Asís y su naturaleza inmaculada parece inspirada en los Evangelios: Lazzaro es el servidor de todos (Mt 20, 28: No he venido ser servido sino a servir); el amigo fiel (Mt 28, 20: Yo estaré con vosotros todos los días, hasta el fin del mundo), el que pone la otra mejilla (Mt 5, 39: No resistáis al que es malo; antes, a cualquiera que te hiera en la mejilla derecha, vuélvele también la otra). Su esencia es bienaventurada (Mt 5, 1-10): Lazzaro 
es manso (Bienaventurados los mansos, porque ellos heredarán la tierra), es pacífico (Bienaventurados los pacificos porque ellos serán llamados hijos de Dios) y es, sobre todo, limpio de corazón (Bienaventurados los limpios de corazón, porque ellos verán a Dios).

Rohrwacher define Lazzaro Felice como una fábula, casi diríamos una parábola por su poderosa dimensión religiosa. Lazzaro es un cordero, ciertamente, pero es el Cordero de Dios (como ha señalado Andi, 2019). Lazzaro es un ser tocado por la "gracia", es la presencia de Dios en la vida cotidiana de los campesinos de Inviolata. Lazzaro simboliza la pureza, "lo sagrado», la luz en la oscuridad que le rodea. En un mundo en el que los personajes sobreviven a duras penas, Lazzaro trabaja incansable, nada le perturba, su mirada es siempre franca e inofensiva. Es una figura salvífica de ecos cristológicos que la directora contrapone a su alrededor para abrir una ventana a la esperanza. Rohrwacher nos invita a mirar el mundo a través de los ojos de Lazzaro, a sumergirnos en él, quizá en esa mirada limpia resida la salvación, quizá en esa mirada podamos encontrar una salida al mundo desesperanzado, descreído e insolidario en que vivimos.

En el plano narrativo, el personaje impacta de igual modo porque carece de raciocinio, percibe el mundo como los niños, su contenido es sólo su alma, conoce el mundo de una manera espiritual, pura, simple, lo que algunos personajes perciben como la «nada». En un momento del film las jóvenes campesinas se burlan de él, la escena se desarrolla en un manantial donde están lavando la ropa cuando aparece Lazzaro: «¿Quién viene?», dice una de las muchachas, y otra responde: «Nadie, Lazzaro».

También, desde el punto de vista formal, la directora emplea un lenguaje que traduce la personalidad transparente de Lazzaro: planos frontales, abiertos, francos como él, a veces ligeros contrapicados lo muestran por encima de nuestros ojos como a un ser que viene «de lo alto». Sobre la manera de enfocar al personaje declara en una entrevista:

En Lazzaro Felice decidimos además no hacer uso de las máscaras del recuadro. Decidimos hacerla con un recuadro abierto. Con Hélène Louvart, la directora de fotografía, tomamos la decisión de no esconder nada, de dejar el cuadro tal y como es, sin hacerle correcciones. Lazzaro es un personaje que no tiene nada que ocultar, así que queríamos darle el mismo tratamiento a la imagen (Atehortúa, 2021).

La cámara le enfoca, por tanto, de manera objetiva, le sigue de cerca, muestra sus limitados movimientos, su robusta figura sin apenas gestualidad, su mirada abierta, su semblante que es todo gentileza y amor, y a veces la cámara lo mira desde lo alto: Dios observa a su Hijo. La directora de fotografía, Hélène Louvart, lo expresa de este modo:

Establecimos tres formas diferentes de filmar, y cada escena solo tenía una o dos de las tres formas de filmar. La primera fue una cámara cercana al hombro que sigue las acciones y los personajes de forma normal y sin ningún punto de vista particular: estamos con Lazzaro y con el grupo de personas, y estamos filmando «justo lo que está pasando frente a nosotros». La segunda es una cámara de pie, fija, panorámica o viajera donde nos acercamos a él, con una distancia focal más 


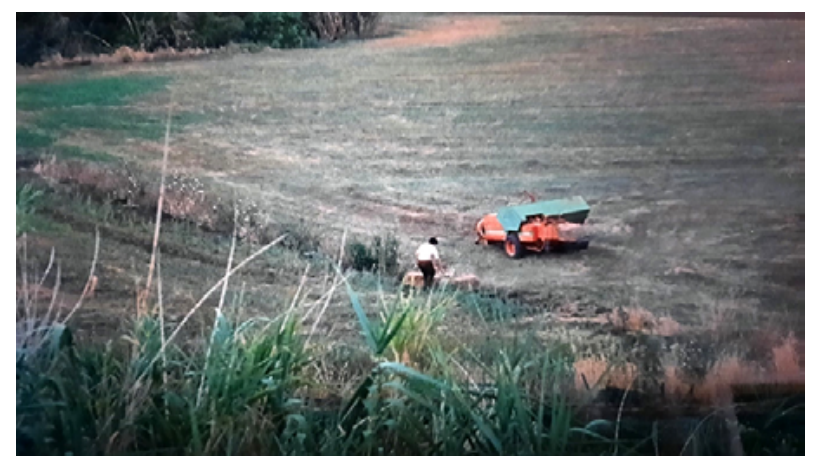

Fig. 17. Lazzaro es observado por la cámara desde lo alto. Dios observa a su Hijo. Fotograma del film.

ajustada que solo encaja a Lazzaro en el grupo; o, incluso si está solo, está «desapegado» del contexto circundante. Generalmente en ángulo bajo. Él está, en cierto modo, «magnificado» por el entorno, es decir, por la forma de mirarlo. Luego, la tercera forma de filmar es una noción de punto de vista que se aleja claramente de la narración, con marcos más amplios y, con mayor frecuencia, en altura. Un poco como una «entidad» observando a Lazzaro (AFC, 2018).

El guion narrativo presenta a Lazzaro con idéntica sobriedad de lenguaje, apenas habla, sus diálogos son muy concisos, su expresión siempre lacónica. Carece de palabras y también de historia: no tiene padres, dice a su amigo Tancredi en un momento del film. Es un personaje al que se priva conscientemente de recursos narrativos que no sean su sola presencia, y esto es así porque Lazzaro, como hemos dicho, es un personaje espiritual cuyo poder radica en su abrumadora simpleza. Su actitud frente al mundo es sincera, generosa, sin malicia, lo que se refleja en su luminoso rostro, el bello rostro de grandes ojos y sonrisa franca de Adriano Tardiolo, que interpreta a Lazzaro con prodigiosa naturalidad como si ambos, actor y personaje, fueran la misma persona. A este respecto, el actor catalán Sergi López (que interpreta a Ultimo, el timador con quien convive Antonia y su familia en los suburbios urbanos) declara en una entrevista (Fernández, 2018): «[Tardiolo] Es una pasada. Desarmante. Podía equivocarse o ponerse nervioso, como cualquier actor profesional, pero luego te daba las gracias o te pedía perdón, te miraba, y te desarmaba. Sí, es un poco como el personaje, pero no tan acentuado». Adriano Tardiolo ha conseguido crear un personaje maravilloso, único, tanto que el espectador experimenta la necesidad de asirse a su alma pura. Rohrwacher construye a su protagonista no sólo para contraponerlo a los que le rodean sino también para ponerlo frente a nosotros como espectadores y sugerirnos que en Él se encuentra la salvación.

El personaje se configura, como venimos diciendo, a partir de referencias cristianas muy directas. Antes que nada, el propio título de la película y el nombre de su protagonista remiten al Evangelio de Juan (Jn 11, 1-45), pasaje donde se relata la resurrección de Lazzaro (hermano de Marta y María de Betania, amigos 


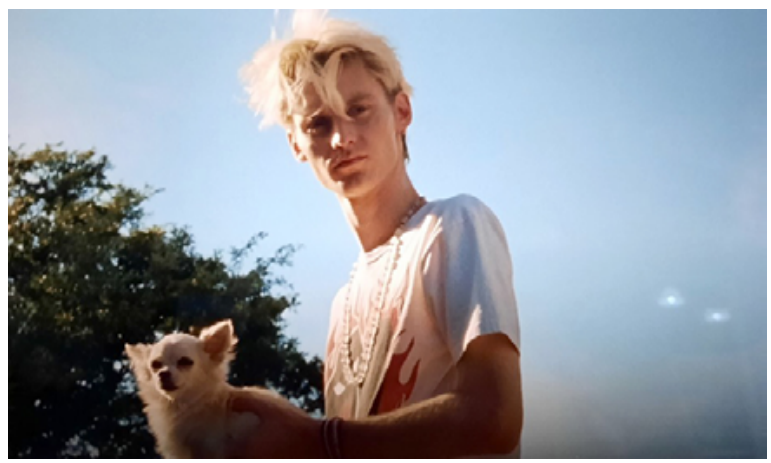

Fig. 18. Tancredi con su perro Ercole. Fotograma del film.

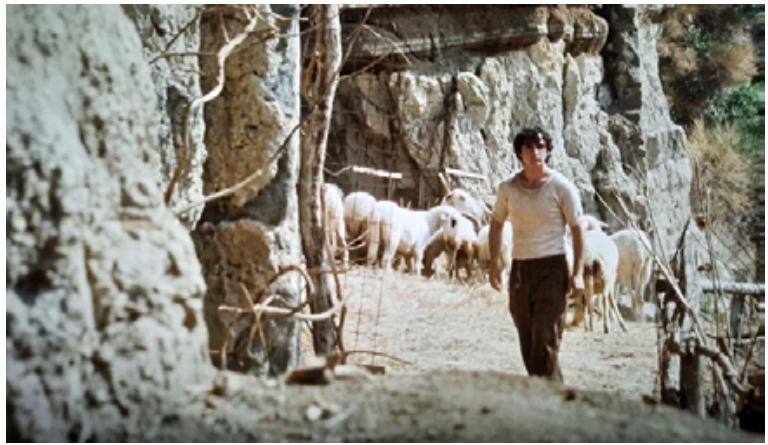

Fig. 19. Lazzaro como representación del Buen Pastor. Fotograma del film.

de Jesús de Nazaret), a quien éste resucita de la muerte. El Lazzaro de Rohrwacher también resucita en la película constituyendo una de las claves fundamentales para la interpretación religiosa del film (el fundamento de la fe cristiana es la creencia en la resurrección y Lazzaro es, sin duda, un santo cristiano). Pero también Lazzaro alude a otro personaje de las Escrituras que aparece en el Evangelio de Lucas (Lc 16, 19-31), en la parábola «El rico Epulón y el pobre Lazzaro»:

Había un hombre rico, que se vestía de púrpura y de lino fino, y hacía cada día banquete con esplendidez. Había también un mendigo llamado Lazzaro, que estaba echado a la puerta de aquél, lleno de llagas, y ansiaba saciarse de las migajas que caían de la mesa del rico; y aun los perros venían y le lamían las llagas...

El paralelismo con el pasaje de Lucas se hace patente en una escena de la película. Tancredi (el rico hijo de la marquesa) pasea ante los campesinos que descansan a la hora de comer. Pese a la arrogancia con que Tancredi mira a sus apareceros, Lazzaro (el joven pobre) le invita a compartir su pan, el joven marqués rechaza 
con desdén el ofrecimiento, pero lo piensa mejor y, con la intención de burlarse de él, le dice que su perro Ercole tiene hambre (la ironía etimológica del nombre del mítico Hércules se hace evidente cuando vemos al minúsculo perro que lleva en los brazos). Lazzaro, ajeno a la malicia del marqués, acerca su pan a Ercole que, tras olfatearlo, se aleja... Sin ofenderse por el agravio del joven rico, Lazzaro le presenta "la otra mejilla» y le ofrece café. De este modo, lo conduce a su pequeño refugio en lo más alto del monte, donde suele ir a descansar, su humilde habitáculo tiene por vecinas a las ovejas (el Buen Pastor que cuida a sus ovejas). Al moderno Tancredi (de cabello oxigenado y ropa estilosa) le parece muy "chulo» el refugio de Lazzaro. Comienza en este momento una bonita amistad entre los dos jóvenes que, como dice Rohwacher, es tan fuerte que atravesará el tiempo.

\section{LA AMISTAD CON TANCREDI, EL REFUGIO DE LAZZARO}

Lazzaro y Tancredi sellan su amistad con un pacto de caballeros, al modo de los antiguos cruzados medievales, que recrea el imaginativo hijo de la marquesa. El nombre de este personaje parece aludir a Tancredo de Galilea, uno de los líderes de la Primera Cruzada católica contra los musulmanes ${ }^{4}$. El joven marqués organiza su propio secuestro y obliga a Lazzaro a unirse al plan urdido por él para pedir dinero a su madre, a la que considera la "enemiga» de los caballeros templarios. De este modo se dirige al joven campesino (don Quijote a Sancho): «Es una zorra explotadora. Se piensa que sois animales. Tenemos que enfrentarnos a ella como caballeros andantes». Y de inmediato se pone a recitar de manera muy teatral unos versos del Orlando Furioso de Ariostó:

¡Oh, gran virtud de antiguos caballeros!

Eran de ley diversa, eran rivales:

Por todo el cuerpo, de los golpes fieros, aún llevan el dolor y las señales.

Y por fragosos bosques y linderos, ¡sin sospechas van juntos y leales!

La amistad con Tancredi es una revelación para Lazzaro, al día siguiente el marqués le entrega el arma (que no es más que un tirachinas) solemnemente: «Yo te entrego esta arma como muestra de nuestra amistad. No la pierdas nunca. Es el arma para enfrentarnos a todos los marqueses del mundo». Lazzaro repite como

${ }^{4}$ Asimismo, Tancredi es el título de una tragedia de Voltaire escrita en 1760 y ambientada en la Primera Cruzada, en la que se basó la ópera homónima de Rossini de 1813.

${ }^{5}$ La relación entre la obra de Cervantes y la de Ariosto ha sido objeto de una amplia reflexión académica en el campo de la literatura. Citamos aquí, a modo de ejemplo, una breve sentencia del Quijote: «Yo - dijo don Quijote- sé algún tanto del toscano y me precio de cantar algunas estancias del Ariosto» (capítulo LxII, segunda parte de El ingenioso cabellero don Quijote de la Mancha, Miguel de Cervantes). 


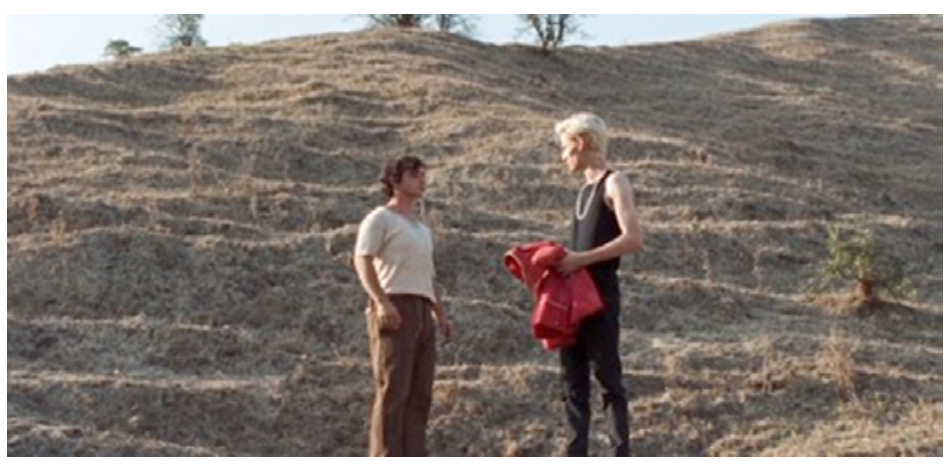

Fig. 20. Tancredi dice a Lazzaro que pueden ser medio hermanos. Fotograma del film.

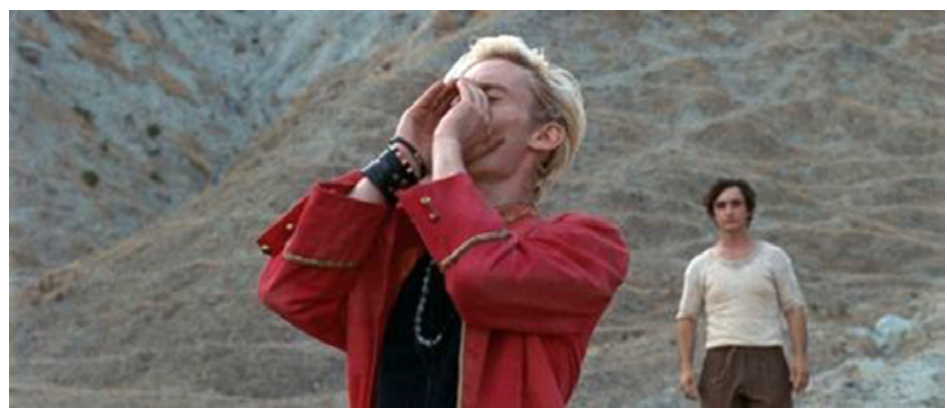

Fig. 21. Tancredi y Lazzaro se divierten imitando el sonido del lobo. Dosier de prensa del Festival de Cannes 2018.

un niño que aprende las palabras por primera vez: «el arma» (anticipo de su trágico final). Más tarde el joven marqués le pregunta por su familia y cuando Lazzaro le responde que no tiene sino a la abuela, el joven dice: «No, ahora me tienes a mí también. No me extraña que fuésemos medio hermanos. Mi padre era un mujeriego». Para el bueno de Lazzaro esto supone una revelación. Ahora adquiere la condición de hermano, en la banda sonora comienza una pieza musical extradiegética (que escuchamos anteriormente en relación con Tancredi) y Lazzaro, en un plano con un ligero contrapicado, mira sonriendo a su medio hermano, que inicia el descenso por una cañada que le parece la luna. Al final del día, ambos jóvenes escuchan al lobo y se entretienen largo rato imitando su sonido.

La relación entre los dos muchachos habría sido improbable en otro contexto. Para Lazzaro es una amistad fabulosa que le descubre un mundo desconocido, su vida hasta ese momento no es más que servir y trabajar como un esclavo. Ahora, junto al imaginativo Tancredi conoce también la aventura, la diversión propia de su edad, la alegría de la adolescencia pasa a ser parte de su vida en Inviolata. 


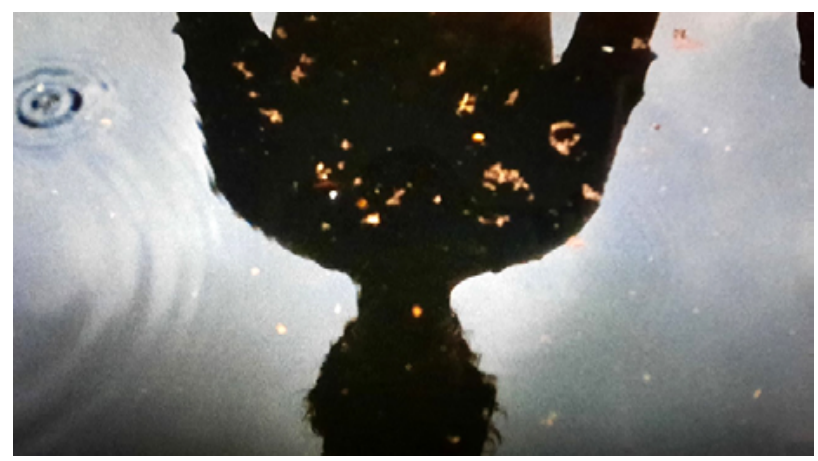

Fig. 22. Imagen de Lazzaro reflejado en el agua del pozo.

Fotograma del film.

Como declara la propia Rohrwacher, el film «habla de una amistad que atraviesa el tiempo». El encuentro entre estos dos jóvenes de distinta procedencia y personalidades tan diferenciadas produce en Lazzaro tal impresión que cuando Tancredi le acusa de no ser un buen hermano porque tiene que ir a trabajar en lugar de quedarse con él, el pobre Lazzaro pasa el día sumido en la desolación. Cuando llega la noche se mira en el agua del pozo, su figura se refleja invertida y oscura (presagio de su muerte), la conmoción es profunda y permanece largo rato de pie bajo la lluvia.

Las niñas de la casa que le ven dicen que se ha vuelto a quedar «atontado» y van a buscarle. Lazzaro tiene fiebre, dicen que se muere. Luego bromean: «Habrá pasado bajo el árbol maldito», dice uno de los jornaleros, o «quizá se está haciendo el inocente», añade con malicia. Luego una de las mujeres dice que tiene que dormir en una habitación, pero viven tan hacinados que todas las camas están ocupadas por cuatro o más personas y no encuentran hueco para él (lo que sugiere que habitualmente no duerme en el interior de la casa). Al final lo acuestan junto a la abuela. A la mañana siguiente, Lazzaro se despierta sin fiebre, se levanta, coge el pan junto a la mesa y emprende el camino en busca de su nuevo hermano. La imagen da paso a otra de Tancredi cogiendo fruta de los árboles. De pronto, se da cuenta de que el móvil tiene cobertura y llama.

En casa de la marquesa, Teresa, la hija de Nicola, está inquieta por no saber de Tancredi, se oye en off la voz de la marquesa dando clase de religión a las niñas: "Aquel que se conoce bien a sí mismo se humilla ante su propia presencia, y las alabanzas de los demás no le causan placer alguno. Si conociera todas las cosas del universo y desdeñara la caridad, ¿quién me proporcionaría la gracia de Dios? ¿Quién me juzgaría por mis actos? Uno debe ir más allá de su sed de conocimiento puesto que distrae y decepciona».

Suena el teléfono, Teresa lo coge. Tancredi dice que entreguen el dinero del secuestro o lo matarán. Voz en off de la marquesa: «¿De qué sirve el conocimiento sin temor de Dios? Un campesino humilde es mejor siervo del Señor que un erudito que se descuida e investiga». Vemos con ironía cómo la marquesa enseña a las 


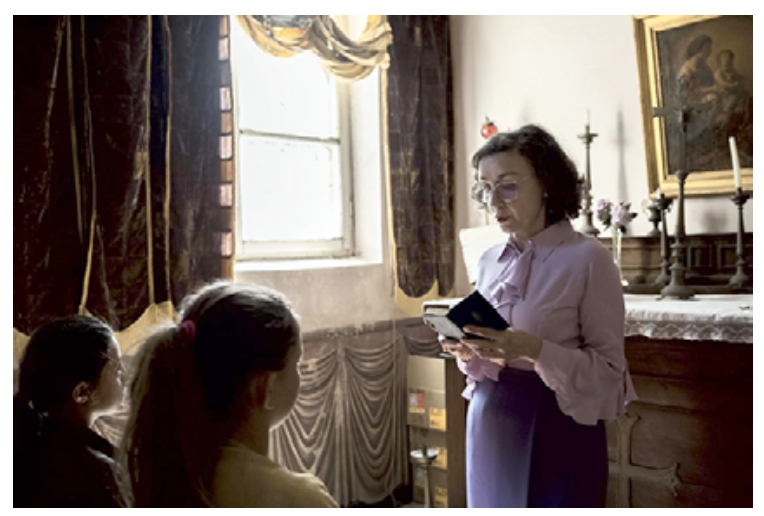

Fig. 23. La marquesa de Luna lee pasajes de las Escrituras a las niñas campesinas.

niñas la virtud de la caridad e incluso afirma que permanecer en la ignorancia es una cualidad. Mientras tanto, ella explota a sus familias manteniéndolas engañadas, viviendo en la miseria y codiciosamente les arrebata alimento y salario. Una acusación directa a cierto tipo de mentalidad católica basada en la hipocresía. Rohrwacher explica la diferencia entre la religiosidad humana y la institucional que quiso reflejar en el film:

En Lazzaro Felice quise poner dos religiones. Una es la religión de los seres humanos, aquella que trabaja por la unificación de la humanidad. Esta unificación no se debe entender en un sentido económico de globalización, sino en un sentido espiritual, como en una especie de fraternidad humana (aunque la palabra fraternidad siempre es peligrosa). Esta religión es fallida, pues no ha podido lograr su cometido, y en ella Lazzaro es un santo que es asesinado una y otra vez, pero siempre regresa. Por otro lado, quería dejar claro que hay otra religión, la religión oficial que es usada por la marquesa para poder dominar a la gente y obtener poder sobre ellos. La marquesa enseña esta religión en la que nunca se trae alimento para la gente, sino, por el contrario, un precio, una deuda. La religión es un instrumento que hipnotiza con sus historias (Atehortúa, 2021).

Al final de la secuencia, Teresa llama en secreto a la policía y le informa de que han secuestrado a un marqués. Se corta la escena y se escucha el sonido de un helicóptero que se acerca a la zona (vista aérea de Inviolata). Tancredi lo oye, mira arriba y sonríe. En ese momento Lazzaro va camino del refugio, oye también el sonido, mira a lo alto, resbala y cae por un precipicio. Cuando Lazzaro cae, escuchamos en off a Antonia narrar la historia de san Francisco y el lobo mientras una cámara subjetiva, que reproduce la mirada del lobo, recorre los escarpados cerros de Inviolata, los campos donde trabajan los campesinos, olfateando, rastreando, buscando a alguien... En paralelo asistimos a la llegada a la aldea del helicóptero y el efecto que producen en uno de los gendarmes las míseras condiciones en que vive 


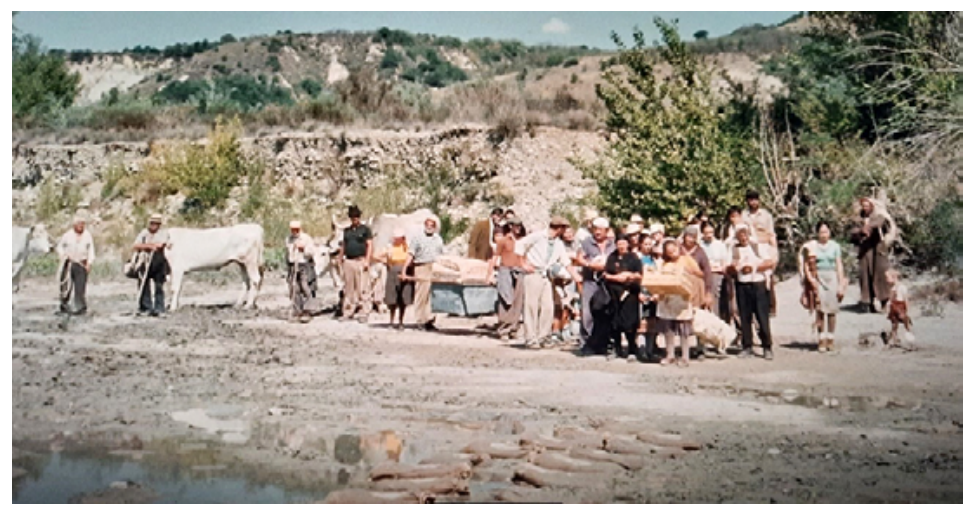

Fig. 24. Los campesinos inician temerosos el éxodo a la ciudad.

Fotograma del film.

aquel medio centenar de aparceros que declaran, entre otras cosas, que pertenecen a la marquesa y que los niños no van a la escuela porque eso es para los ricos. Mientras todo esto sucede y vemos más tarde a los campesinos iniciar temerosos el éxodo forzoso a la ciudad cargados con sus míseras pertenencias y a Antonia preguntando por Lazzaro, la cámara abandona el autobús que traslada a los campesinos y vuelve a la mirada del lobo (en cámara subjetiva) recorriendo los montes. La voz en off de Antonia se escucha de nuevo: «Y llegó el invierno. El santo estaba exhausto, helado y hambriento. Pero no había ni rastro del lobo. No sabía que el lobo también tenía hambre y que llevaba tiempo siguiéndole el rastro. El santo se desplomó en la nieve muerto de cansancio. Entonces, el lobo lo encontró...».

Pasamos a una imagen de Lazzaro tendido en el fondo del precipicio y el lobo que se acerca, lo olfatea. Voz en off de nuevo: «El lobo se acercó, afiló las uñas, y preparó los dientes, listo para devorarlo, pero... De pronto olió algo que nunca había olido, se detuvo, lo olfateó de arriba abajo. ¿Qué era ese olor? Era el aroma de un hombre bueno".

Lazzaro despierta, un resplandor ilumina su rostro, toda la escena aparece iluminada por una luz radiante. La simbología religiosa es patente: Cristo se revela a sí mismo como luz (Jn 8, 12: Yo soy la luz del mundo; el que me sigue, no andará en tinieblas, sino que tendrá la luz de la vida). La cámara se detiene largo rato en la luz que resplandece en el rostro de Lazzaro mientras se incorpora. La luminosidad que muestran todos los planos de la escena actúa como símbolo de la presencia de Dios. Lazzaro ha resucitado. Sabremos, a medida que avanza la narración, que han transcurrido más de veinte años. Lazzaro con idéntica apariencia física, la misma expresión sencilla y la misma candidez de espíritu, como si el tiempo no transcurriera para él, pasa «inalterado» del pasado al presente e inicia su camino hacia el calvario. 


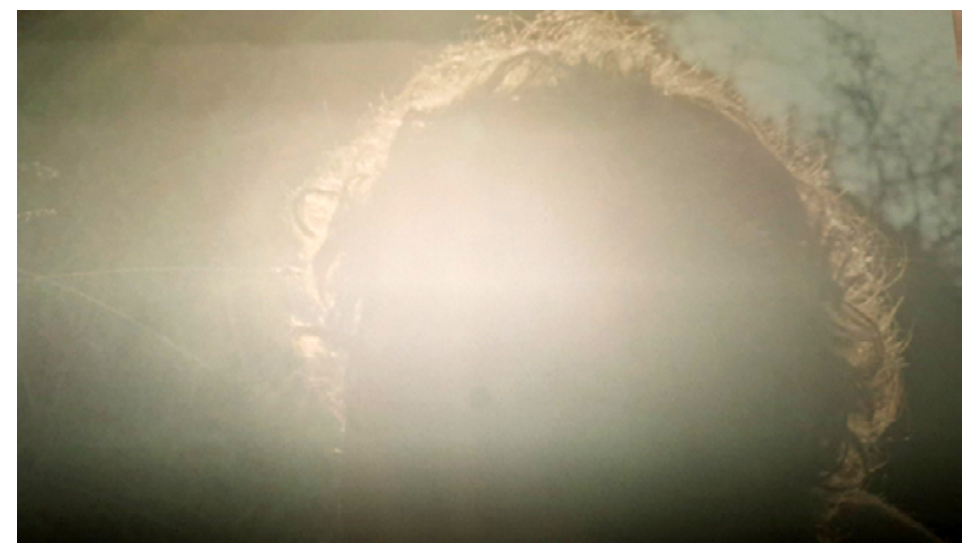

Fig. 25. La Luz brilla en el rostro de Lazzaro resucitado.

Fotograma del film.

\section{LA PASIÓN DE LAZZARO}

Tras descubrir por unos pícaros ladrones (que se encuentran saqueando la casa de la marquesa) que Tancredi se ha marchado, Lazzaro inicia un largo camino en busca de su amigo. Cuando llega a la ciudad se produce un encuentro fortuito con Antonia (ya adulta), quien al ver a Lazzaro con la misma apariencia física que tenía en Inviolata ańos atrás, cree haberse vuelto loca; después de acercarse y comprobar que efectivamente es Lazzaro, se arrodilla ante él y ordena a los que la acompañan (que no son otros que los saqueadores de la marquesa) que lo hagan también. La escena es profundamente conmovedora pero la directora, quizá para romper la solemnidad, le añade una pincelada de humor: los pillos la obedecen de inmediato y el propio Lazzaro lo hace también y se arrodilla, ajeno al hecho de que su presencia es la que origina tal muestra de devoción.

Descubrimos poco después, no sin cierta ironía, que uno de los ladronzuelos es Pippo, el hijo al que Antonia le contaba las vidas de los mártires cristianos. El otro pícaro es Ultimo, personaje que se incorpora en esta segunda parte de la película como novio de Antonia y que interpreta, como habíamos indicado más arriba, el actor español Sergi López. Antonia, pese a las protestas de su novio, decide acoger a Lazzaro y llevarlo con ellos. La secuencia que sigue es una de las más hermosas de la película por su profundidad lírica y su sentido de lo sagrado: construida con la luz del atardecer reflejada en el destartalado carromato, vemos proyectarse las sombras de Lazzaro y Antonia en la lona trasera del vehículo. En la banda sonora vuelve a enmudecer el sonido natural de la escena y sólo se escucha el canturreo de Antonia, que entona una especie de canción de cuna. La pequeña camioneta avanza por la ciudad silenciosa, como flotando en el aire, y en un brevísimo instante, la ligera lona, agitada por la brisa, descubre el interior y nos muestra, como un rayo de luz, la imagen de Antonia y Lazzaro cogidos fuertemente de la mano, unidos fraternal, 


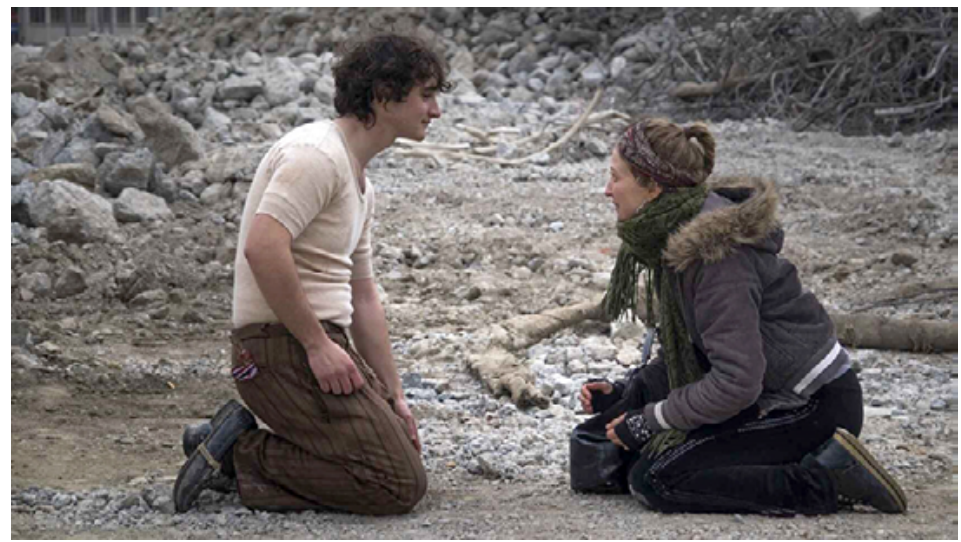

Fig. 26. Antonia y Lazzaro arrodillados en el momento de su reencuentro en la ciudad.

Dosier de prensa, Festival de Cannes 2018.

espiritualmente. Es un momento de recogimiento absoluto, un momento «sagrado». Lazzaro hace su entrada en la ciudad en un humilde y destartalado carricoche (Jesús entra en Jerusalén a lomos de un borrico).

Como habíamos señalado anteriormente, Rohrwacher se vale de una estética muy personal y poética para revelar la presencia de «lo sagrado» en la vida cotidiana de sus personajes, la directora adopta un punto de vista con una enorme carga espiritual para reflejar la naturaleza sagrada de Lazzaro, pero también el idealismo religioso de Antonia. Este personaje femenino (interpretado en su edad adulta por Alba Rohrwacher, hermana de la directora) se caracteriza por dar vida a una joven compasiva y bondadosa, con una enorme sensibilidad espiritual influenciada probablemente por las lecturas religiosas de la marquesa. Desde el inicio de la película, Antonia aparece contando las vidas de los mártires cristianos a su hijo Pippo. También a Lazzaro le cuenta la historia de santa Águeda de Catania (martirizada por el procónsul de Sicilia en el siglo III, en tiempos de las persecuciones contra los cristianos) mientras le muestra su estampa, que, de manera supersticiosa, guarda la marquesa bajo el colchón de la cama. Pero su naturaleza sensible le confiere también una sutil intuición para percibir «algo santo, sagrado» en la persona de Lazzaro. La escena del encuentro con Lazzaro en la ciudad nos muestra la unión que existe entre estos dos personajes, afinidad que se pone de relieve a lo largo de la trama. En esta segunda parte, vemos a Antonia convertida en una mujer adulta que en cierto modo lleva las riendas de la familia y que se dedica, como los demás, a timar a los viandantes para poder sobrevivir en la ciudad. Incluso intenta aprovecharse de la apariencia cándida de Lazzaro para timar a una mujer a la que vende una tabaquera robada en casa de la marquesa. Sin embargo, inmediatamente se nos muestra el arrepentimiento de Antonia cuando Lazzaro, viendo el objeto dentro del bolso, le pregunta con inocencia si no se lo dio a la compradora. Antes de que esto sucediera, Antonia había llevado a Lazzaro a su nuevo hogar, un gran tanque indus- 


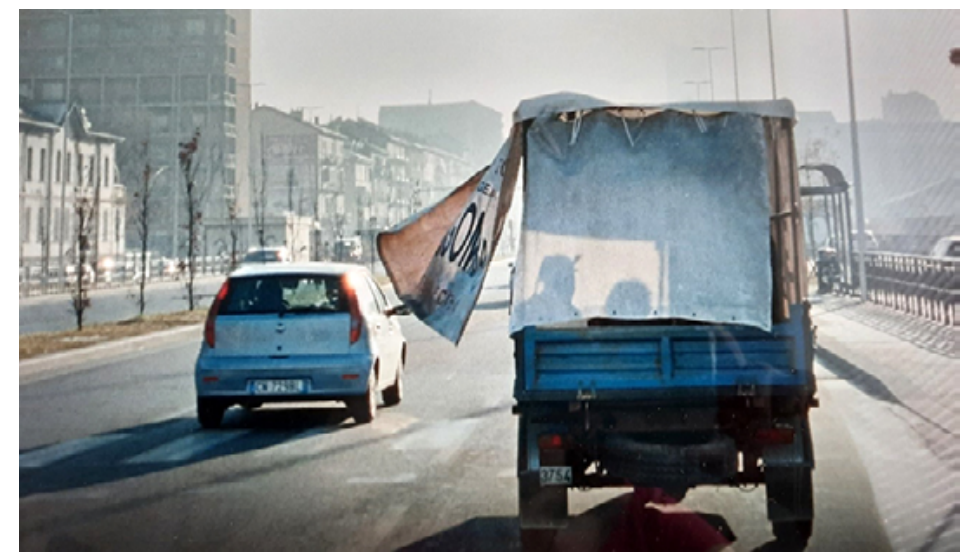

Fig. 27. Imagen poética que muestra las sombras de Antonia y Lazzaro reflejadas en la lona trasera del carromato. Fotograma del film.

trial abandonado junto a las vías del tren en el extrarradio urbano, donde malvive su familia "matando el hambre» con paquetes de patatas chips robadas y viendo la televisión. Un cuadro con estampas de todos los santos parece ser el único vestigio del pasado en Inviolata.

Un lluvioso día invernal Lazzaro prepara manojos de hierbas en las vías del tren cuando aparece Ercole, el perro, ahora maltrecho, de Tancredi. Se oye de lejos a su dueño llamándole, Lazzaro sigue al perro y con regocijo divisa a su amigo, va en su busca, le encuentra bailando en una oscura sala de fiestas. Se acerca, le llama, le dice que es él, Lazzaro, le enseña el tirachinas que selló su amistad en Inviolata y le recuerda que es su hermano, «bueno, tu medio hermano», dice tímidamente. Tancredi (interpretado en su edad adulta por Tommaso Ragno) le mira emocionado y juntos salen a la ciudad. Hacen una visita a los antiguos jornaleros del marqués y celebran una pequeña fiesta por el reencuentro, Lazzaro vuelve a tocar la zampogna, Tancredi, con una cazuela de metal, juega a que es la luna y vuelven a aullar llamando al lobo como aquel verano feliz de la adolescencia, por un instante todos vuelven a ser jóvenes en un juego de planos que muestra imágenes de los niños en Inviolata, y volvemos a escuchar el viento (elemento recurrente en esta película vinculado a Lazzaro y también precediendo los momentos emocionales de los personajes, en este caso los recuerdos de Lazzaro de la vida lejana en el campo). Más tarde, Tancredi dice a todos que debe irse y los invita a almorzar al día siguiente en su casa. Los mendigos se ponen sus mejores galas, compran una bandeja de pasteles muy caros y acuden al domicilio. Teresa, la hija de Nicola, ahora esposa de Tancredi, abre la puerta y tras unos instantes de confusión va a preguntar dentro de la casa, se oye a Tancredi: «Déjame en paz». Teresa vuelve a la puerta y les dice que ha debido haber algún malentendido. Los mendigos se van, Lazzaro se aleja apesadum- 


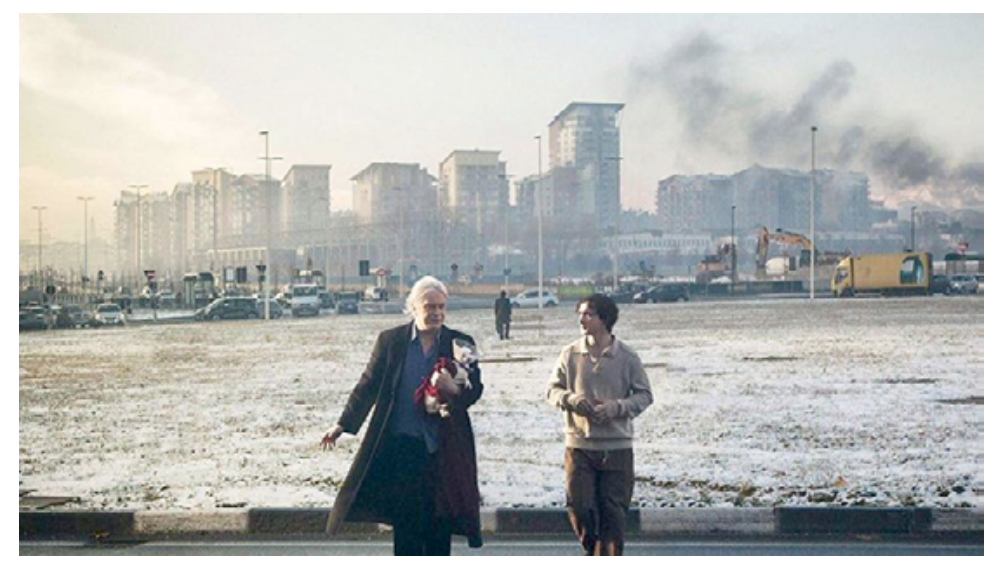

Fig. 28. Reencuentro entre Lazzaro y Tancredi (envejecido) en la ciudad. Fotograma del film.

brado. Teresa vuelve a llamar. Ahora Lazzaro sonríe animado y exclama: «iEra una broma!». Pero se equivoca. Teresa les suplica que le dejen los pasteles. Ante las protestas de los demás, Antonia compadecida se los da y le pregunta cómo han llegado a esa situación. Teresa grita: «Ha sido la banca, son unos monstruos, nos lo quitaron todo. Y no nos queda nada. Son unos estafadores». Lazzaro repite para sí: «la banca».

Vemos ahora el plano de las manos de un músico que toca el órgano. Luego otro de Lazzaro en la calle, que escucha la música profundamente emocionado; en segundo término, los mendigos intentan arrancar la camioneta, que se ha averiado. Antonia se acerca a Lazzaro y le dice: "¿iTe gusta? ¿Quieres ir a escucharla?». "Síı,, responde Lazzaro. Y se dirigen todos a la iglesia de donde proviene el sonido del órgano. Entran, se persignan y, de pronto, una monja que advierte su presencia se acerca corriendo y les dice: «No, no, no». «No pueden estar aquí, tienen que irse. Es una función privada. Márchense, por favor». «Sólo queremos oír la música», dice Antonia...». «En otra ocasión, váyanse por favor». "No molestamos a nadie», insiste Antonia. El organista se levanta a ver qué ocurre, vemos un plano de Lazzaro, la monja le dice que se vaya también. Antonia le llama. Luego la monja dice «Carlo, comienza de nuevo». Éste empieza a tocar y las teclas no emiten sonido. Escuchamos de nuevo el sonido del viento, sabemos que va a ocurrir algo... Entonces se oye la música, emerge de ninguna parte, autónoma, con entidad propia, adquiere casi una cualidad física. Las monjas miran a lo alto sobresaltadas, una de ellas grita: «¿Adónde va? ¡Se marcha! ¡La música se va! ¡Cerrad la puerta!». La escena presenta una palpable crítica a ciertas actitudes del clero católico que se considera propietario de la casa de Dios.

Pero sigamos a nuestros mendigos, que, expulsados del templo, vuelven a empujar el carromato averiado. Hacen un pequeño descanso y de pronto escuchan 


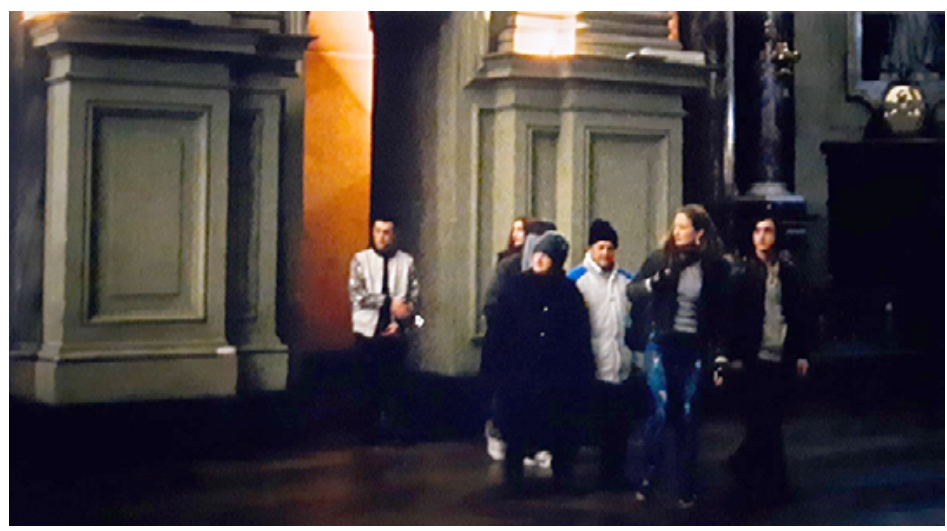

Fig. 29. Los mendigos entran en la iglesia a escuchar la música del órgano. Fotograma del film.

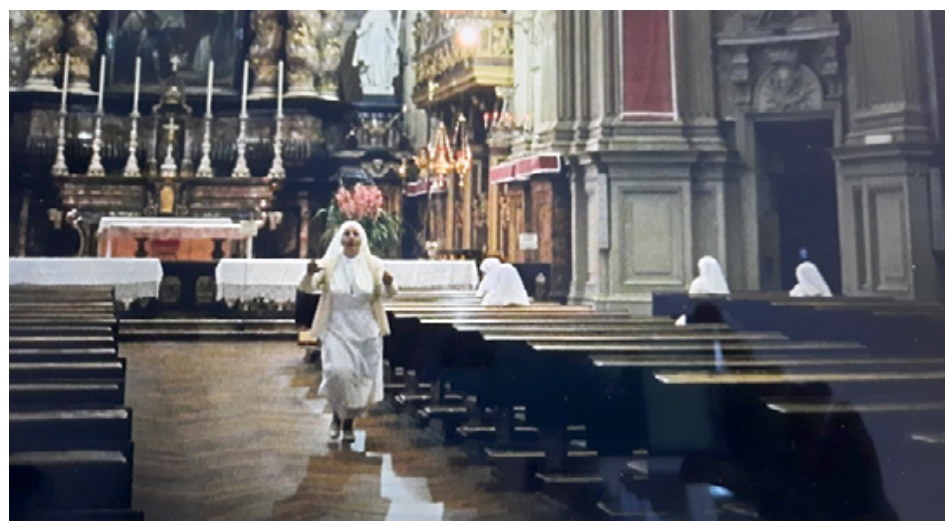

Fig. 30. La monja ordena a los mendigos que abandonen la iglesia. Fotograma del film.

la música: «¿Lo oís?», dice Antonia, «iLa música! ¿De dónde viene? ¡La música! ¡Nos sigue!». Todos miran al cielo sonriendo... "Va por el cielo», dice el anciano campesino. Vemos a Lazzaro ensimismado. La música sigue sonando sobre ellos y de nuevo intentan echar a andar el vehículo. Lazzaro deja de seguirlos.

La película nos muestra cómo después de ser expulsados del templo, la música del órgano sale de la iglesia tras los mendigos, tras Lazzaro. La música diegética sale del marco que le corresponde en la narración y corre tras los personajes. Un hallazgo estilístico intensamente conmovedor. Como ya hemos señalado, mediante el lenguaje visual y sonoro se crea una nueva imagen simbólica, se otorga 


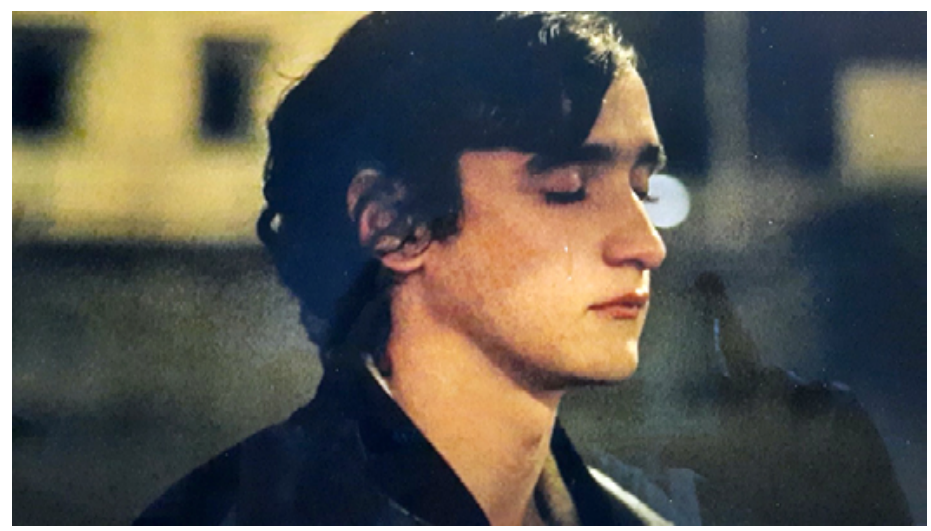

Fig. 31. Lazzaro como el Siervo sufriente de Dios.

Fotograma de la película.

a la escena una carga lírica en medio de la narración realista que la trasciende para presentarnos una idea sublime: la música religiosa, «lo sagrado», abandona el lugar al que supuestamente pertenece (la iglesia) y corre hacia quien es más digno de ella, Lazzaro. La propia directora manifestó la finalidad de esta escena:

Para mí era importante que la música se fuera con Lazzaro, porque si ella tiene que estar con alguien, debe ser con él. Dándole vida autónoma a la música, ella se vuelve algo físico, algo que se puede tocar (Atehortuá, 2021).

Mientras Lazzaro se queda atrás, los campesinos siguen empujando el carricoche y hablan entre ellos de volver a la aldea: «Oye, ¿tú te acuerdas de Inviolata?», dice Pippo. «No, era muy pequeña», responde Estefanía. «Si aquello está abandonado, ¿por qué no volvemos y nos hacemos con el control?», propone Pippo, y añade "iHasta tenemos las llaves!». Antonia dice: «No podemos, no es nuestro». Su hijo contesta: «Siempre te quejas de que lo construiste con tu esfuerzo y tu sudor. Podríamos asentarnos allí, pero sin patrones». «¿Sin patrones?», pregunta el anciano.

«Pausa», grita Antonia, y se detienen. Pippo continúa: «iSería genial!». Su madre le dice: "La música te ha dejado atontado», y entonces repara en que Lazzaro no los ha seguido. Pipo le llama. Lazzaro se ha quedado parado en medio del camino. «`Ven!», grita Pippo, pero Lazzaro no se mueve. Antonia dice: «Déjale en paz. Ha sido un golpe duro para él, vamos» y emprenden el camino. «Ya nos seguirá él», añade Antonia, y pregunta a su hijo: «¿Quieres volver a Inviolata?». Pippo responde: «Sí, ¿no te alegra?». Todos ríen. "Quiere volver al campo para labrar la tierra», dice Antonia. Las voces se alejan.

Vemos a Lazzaro sufrir injustamente, el inocente ha sido traicionado por su amigo (Judas); también quizá por presenciar cómo se ha "profanado» la Casa de su Padre (la iglesia "farisea» ofrece conciertos privados en el templo). Lazzaro se ha 


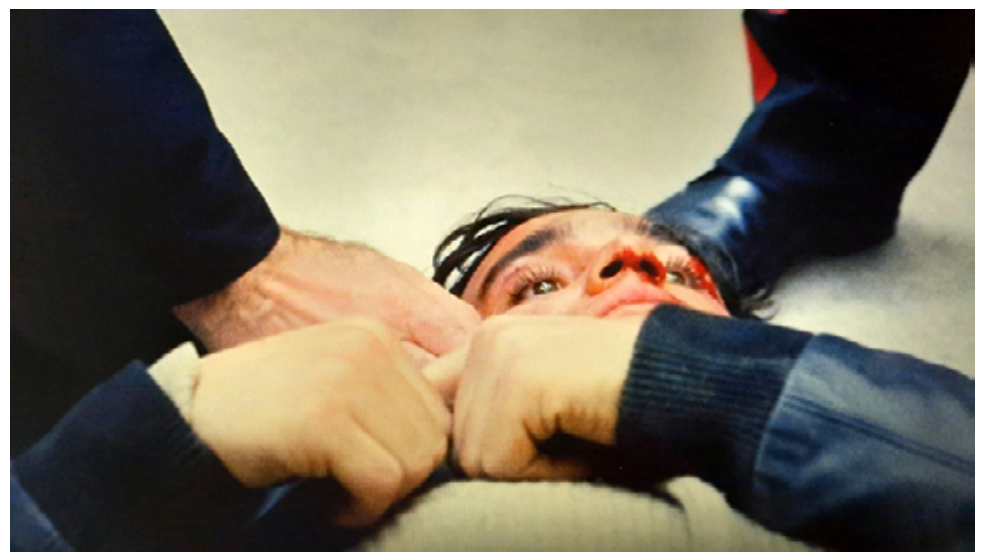

Fig. 32. El Cordero de Dios ha muerto apaleado por la gente.

Fotograma de la escena final del film.

transformado, ya no es Lazzaro Felice. En el frío de la ciudad se dirige hacia unos árboles al borde del camino, seguimos escuchando la música del órgano y a lo lejos, las risas alegres de los campesinos. Lazzaro mira a lo alto. Una radiante luz se refleja en un árbol, la naturaleza manifiesta nuevamente la presencia divina ${ }^{6}$. Lazzaro acaricia la hierba, (recuerda Inviolata), después se sienta. Un primer plano nos muestra su rostro afligido, cierra sus ojos tristes, una lágrima desciende por su mejilla. Una sombría y honda desolación le embarga y siente el alma triste hasta la muerte (Jesús en Getsemaní, Mt 26, 38: Mi alma está triste hasta la muerte). La dolorosa escena se corta con un plano de la luna.

Corte y la acción se traslada a la mańana siguiente. Lazzaro entra en la sucursal de un banco, hay una cola de gente, él se adelanta, pide que le devuelvan sus propiedades al marqués de Luna, alguien ve el bulto del tirachinas en su bolsillo y cree que es una pistola... La banda sonora anticipa la tragedia, se escucha Erbarme dich mein, O Herre Gott (Ten piedad de mí, Señor, Salmo 51), de Johan Sebastian Bach. La gente de la cola se abalanza sobre el inocente y le golpea furiosa. El «sacrificio» de Lazzaro remite claramente a la pasión y muerte de Jesús. Lazzaro muere apaleado e insultado por los clientes de la sucursal bancaria ${ }^{7}$ sin llegar a saber lo que ocurre;

${ }^{6}$ Greeley afirma que, a diferencia del pensamiento protestante, judío e islámico, que ven una radical discontinuidad entre Dios y el mundo, la sensibilidad religiosa católica ve el conjunto de la creación como una metáfora: todo es gracia (Greeley, 1988, p. 94).

7 Rohrwacher declara sobre la muerte de Lazzaro: «El capitalismo como religión es quizá el gran problema del presente. Al final de Lazzaro Felice el protagonista es asesinado por los propios pobres. Es como si la marquesa, o quien los explota, no necesitara defenderse más, pues son los propios explotados quienes defienden a los ricos. Para mí era importante que al final de la película fuera 


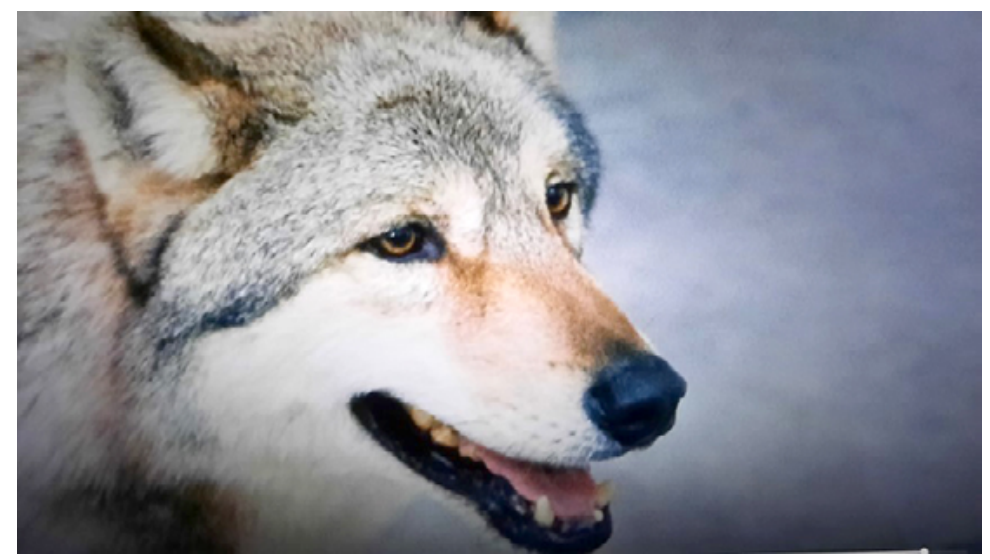

Fig. 33. El lobo, testigo de la muerte de Lazzaro.

Fotograma del film.

los golpes que recibe Lazzaro también los recibimos nosotros como espectadores. El Cordero ha muerto, el sacrificio, anticipado por Antonia en los relatos de mártires cristianos, se ha consumado. La imagen de la muerte de Lazzaro representa una cruz que se forma con sus manos sobre el pecho, el pie de un policía y la mano de otro, en clara alusión a la crucifixión de Cristo.

La carga emotiva y trágica se acentúa con la entrada en la escena del lobo, que asiste como testigo silencioso a la muerte de Lazzaro maltratado por los hombres (Jn 18, 23: «ppor qué me golpeas?»). El hermano lobo de Francisco de Asís que, tras verle en el suelo masacrado, sale del banco y se aleja corriendo por la ciudad en el último plano de la película. Este final no es del todo pesimista, ya que el plano del lobo puede sugerir la resurrección de Lazzaro y, por tanto, la resurrección de Cristo y la esperanza de una vida nueva. Analizamos esta idea con mayor detalle: el lobo está presente en toda la película desde el inicio, igual que el protagonista: primero se percibe como amenaza para los campesinos con la aparición de la gallina y la guardia del lobo, después escuchamos varias veces sus aullidos, más tarde, ya haciendo visible su presencia, es el amigo de Lazzaro (de Asís). El lobo se acerca por primera vez a él, en su muerte en el precipicio, allí siente el «aroma» de su santidad, el lobo simboliza entonces «lo espiritual» y se podría ver como un doble del héroe. Lazzaro no teme al lobo, incluso en la escena en que él y Tancredi escuchan sus aullidos en las montañas de Inviolata, Lazzaro dice: «¿Qué dirá? Es como si llamara a alguien»... Por si fuera poco, hay un plano en la película en el que aparece reflejada en el rostro

la gente normal la que matara a Lazzaro simplemente por la sospecha de que podían llegar a perder algo de lo poco que les queda» (Atehortúa, 2021). 


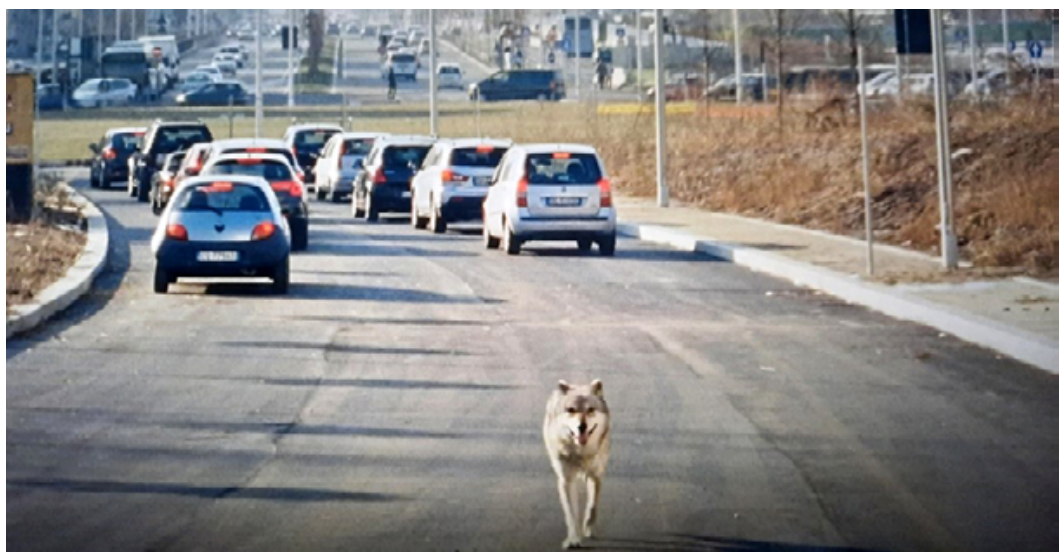

Fig. 34. El lobo se aleja de la ciudad tras presenciar la muerte de Lazzaro. Fotograma del film.

de Lazzaro la sombra del rostro de un lobo (como aparece en los juegos infantiles de sombras chinescas) y en algunas escenas Lazzaro "mira» como un lobo, como si se nos quisiera mostrar esa posible dualidad del personaje. El lobo, que en el medievo era símbolo de un tiempo destructor, de la muerte y el renacimiento, pero también "portador de la cruz», está junto a Lazzaro en el momento de su segunda muerte. Tales indicios nos llevan a pensar que esa imagen final del lobo, corriendo en sentido contrario a los coches, es Lazzaro que vuelve de nuevo. Rohrwacher declara que, con la muerte de su protagonista, quiso expresar «lo que pudo ser y no dejamos que fuera», porque volvimos a «matar a Dios». Pero también, ese plano final del lobo que se aleja de la ciudad y corre, quizá tras los campesinos de Inviolata, representa la resurrección de Lazzaro (de ahí el nombre del protagonista y del film). El final se nos presenta como una invitación a inventar una nueva humanidad, a recuperar la pureza perdida que representa Lazzaro, que representa la fe cristiana.

El plano del lobo corriendo funde a los créditos finales y en la oscuridad escuchamos el sonido de los grillos y de las ranas entremezclados con las voces y risas de los campesinos. La película termina en la oscuridad igual que empezó, el círculo (símbolo de lo divino) se cierra y escuchamos una canción: Il tuo sguardo verso il cielo / è per noi il sentiero / Corri Lazzaro corri / Noi siamo con te (Tu mirada al cielo es nuestro camino, corre Lazzaro corre, estamos contigo). Alice Rohrwacher deja una ventana abierta a la esperanza. Lazzaro es el camino, una fuerza del pasado que retorna una y otra vez porque el Bien no puede ser exterminado:

En Lazzaro Felice sucede lo mismo, al final hay un lobo que corre a través de la ciudad y los coches no lo notan. ¿Hacia dónde se dirige? ¿Por qué lo hace? Para mí es muy importante crear estas imágenes que puedan dejar en la gente esa energía de que algo nuevo está por empezar [...]. Mucha gente ha visto Lazzaro felice como 


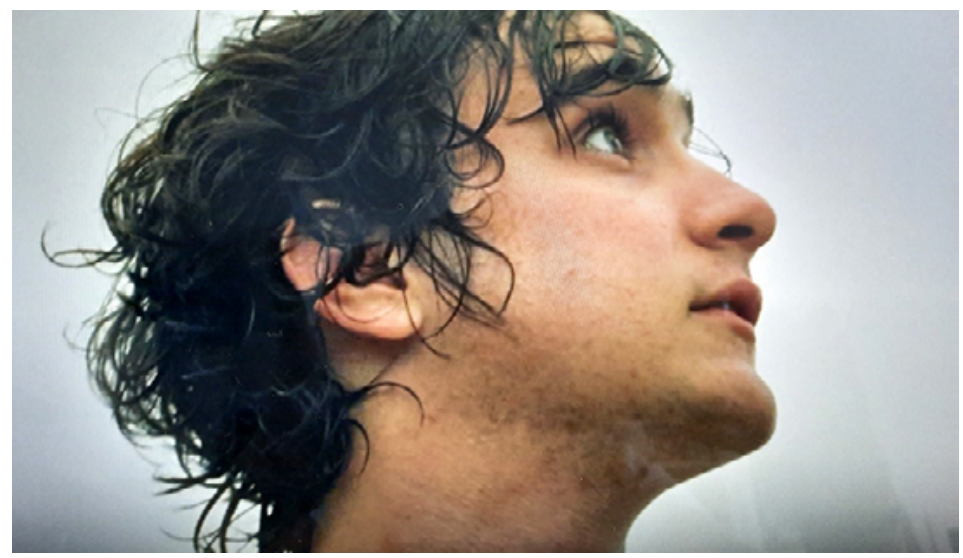

Fig. 35. Lazzaro en una imagen previa a su muerte que recuerda las representaciones de Cristo con la corona de espinas. Fotograma del film.

una película pesimista, y es cierto que puede ser interpretada así, pero como sabemos Lazzaro puede resucitar, y es nuestra responsabilidad, la próxima vez que él aparezca, no permitir de nuevo su muerte [...] Lazzaro es una fuerza del pasado que retorna y retorna porque no puede ser exterminada [...]. Para mí eso es lo que representa el lobo del final que corre en medio de la autopista sin que los coches lo noten (Atehortúa, 2021).

Con un estilo propio, sin agotar la realidad social y política que nos presenta o a través de ella, Alice Rohrwacher logra establecer una conexión espiritual con el espectador. Su finalidad es comunicar, hacernos reflexionar, buscar sentido a la existencia. Sitúa la acción en un escenario rural y más tarde en un escenario del extrarradio urbano donde a través de un personaje que atraviesa el tiempo podemos percibir la verdad, el misterio de la fe, como ella misma expresa: «Una película religiosa donde no hay ninguna religión oficial, sino que es sobre la fe, sobre el martirio y sobre aquello que no podemos ser, pero sí podemos reconocer» (Atehortúa, 2021). La directora reflexiona sobre el lado espiritual de la existencia, sobre el mundo interior que une a todos los seres humanos y propone encontrar en esa conexión la alternativa a una sociedad que ha convertido el capitalismo feroz e inhumano en su nueva religión. Rohrwacher nos invita a emprender una trayectoria diferente, nos invita a reconocer en Lazzaro (Cristo) el único camino "verdadero», y lo expresa en su película a través de la poesía de lo cotidiano, del simbolismo de las imágenes y de la mirada pura de su hermoso Lazzaro.

Reconozco el poder que tienen los símbolos como formas que posibilitan el contacto de dos niveles diferentes de la esencia del ser. El símbolo es la posibilidad que adquiere una imagen de alcanzar un nivel más elevado de la experiencia. Si uno hace películas, como las hago yo y muchos otros cineastas, de algún modo uno está 


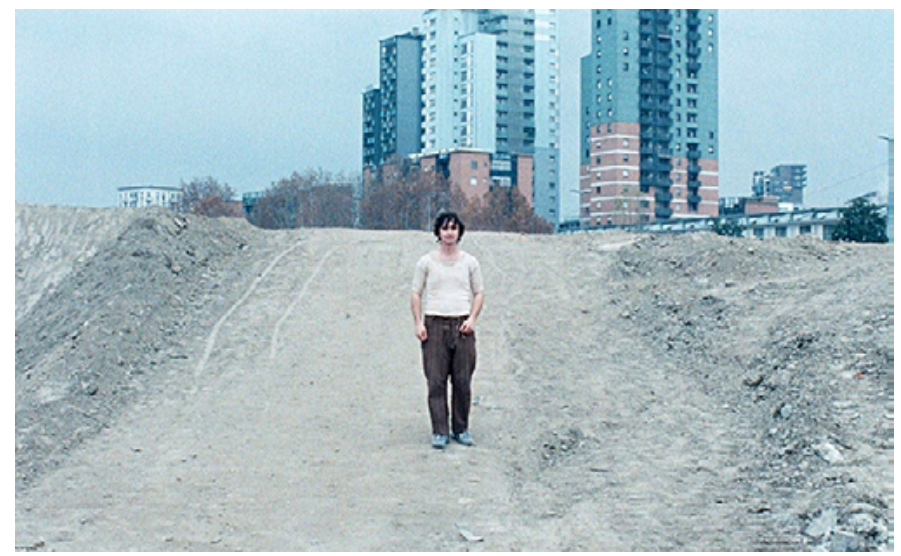

Fig. 36. Lazzaro llega a la ciudad en busca de sus amigos.

Fotograma del film.

siendo una persona religiosa porque está teniendo fe en el poder de las imágenes para abrir y tocar algo más allá de la experiencia (Atehortúa, 2021).

RECIBIDO: 22-6-2021; ACEPTADO: 19-7-2021 


\section{REFERENCIAS}

Andi, A. F. (2019). Lazzaro Felice üzerine bizimkisi bir büyübozumu hikâyesi, Kültur Atlasi, n. ${ }^{\circ} 96$.

Atehortúa, J. (2021). Los cines por venir: Diálogos con autores contemporáneos, Barcelona: Planeta de Libros.

Belinchón, G. (2018, 14 de mayo). "Alice Rohrwacher, ¿̨la segunda cineasta en ganar la Palma de Oro?», El País.

Biblia de Jerusalén (2019). Bilbao: Desclée de Brouwer.

Bird, M. (1982). «Film as Hierophany», Religion in Film (pp. 3-22), University of Tennessee Press: ed. May and Bird.

Cavalcanti, H. (2020). «O homem é o lobo do homem: Hobbes e a natureza humana em Lazzaro Felice», Cinema \& Humanidades: Ensaios multidisciplinares, vol. 2.

Di Bianco, L. (2020). «Ecocinema Ars et Praxis: Alice Rohrwacher's Lazzaro Felice», The Italianist. https://doi.org/10.1080/02614340.2020.1764726.

Díez de Velasco, F. (2008). Breve historia de las religiones, Madrid: Alianza.

Louvart, H. (14 de mayo de 2018). La directrice de la photographie Hélène Louvart, AFC, parle de son travail sur Lazzaro Felice, d'Alice Rohrwacher. Association Française des directeurs de la Photographie. https://www.afcinema.com/La-directrice-de-la-photographie-Helene-Louvart-AFC-parle-de-son-travail-sur-Lazzaro-felice-d-Alice-Rohrwacher.html?lang=fr.

Eliade, M. (2014). Lo sagrado y lo profano, Barcelona: Paidós.

Fernández, F. (2018, 8 de noviembre). Entrevista: «Hablamos con Sergi López, el actor español que aparece en Lazzaro Feliz, la aclamada película de la italiana Alice Rohrwacher», Fotogramas. https:/www.fotogramas.es/noticiascine/a24788029/lazzaro-feliz-sergi-lopez-entrevista/.

FöLdÉNyi, L. F. (2004). El sudario de la Verónica, Barcelona: Galaxia Gutemberg, Círculo de Lectores. Greeley, A. (1988). God in Popular Culture, Chicago: Thomas More.

Guardiola, I. (2019). «Al.legories cinematogràfiques per pensar Europa», Revista Idees, 46, Barcelona: Centre d'Estudis de Temes Contemporanis.

Holmevist, J. (2018). «The ambition that drives Lazzaro Felice», Segmento.

MaY, J. (1982). «Visual Story and the Religious Interpretation of Film», Religion in Film (pp. 23-43), University of Tennessee Press: ed. May and Bird.

MaY, J. (1998). La nueva imagen del cine religioso, Universidad Pontificia de Salamanca.

Mizzi, M. (1999). El mensaje de San Francisco, Madrid: Celeste ediciones.

Nuevo Testamento (2002). Madrid: San Pablo.

Orellana, J. (2004). Como en un espejo, Madrid: Ediciones Encuentro.

PAst, E. (2019). Lazzaro felice by Alice Rohrwacher, GSI (Gender, Sexuality, Italy).

Ratzinger, J. (papa Benedicto XVI) (2007). Jesús de Nazaret, Madrid: La Esfera de los Libros.

Rondini, A. (2018). «Strategie e risultati del Piano B. L'agency nel cinema italiano contemporáneo», Cinergie-Il cinema e le altri arti, n. ${ }^{\circ} 14$.

Sola Antequera, D. (2012). «La pasión de Jesús en el cine contemporáneo», en La verdadera historia de la Pasión según la investigación y el estudio histórico. Madrid: Edaf. 
SAIto, S. (2018). Interview: «Alice Rohrwacher on Creating a Timely and Timeless Tale with 'Happy as Lazzaro" The Moveable Fest.

Tempesta Film (2018). Happy as Lazzaro press kit. 


\section{RECENSIONES}
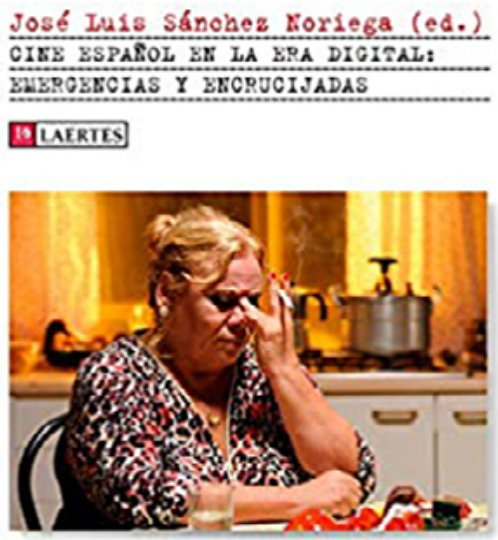

José Luis Sánchez Noriega (ed.). Cine español en la era digital: emergencias y encrucijadas, Laertes (2020).

El trabajo que nos ocupa es el quinto de este ya dilatado ciclo que pretende ser una suerte de Historia del Cine Español y que arrancó allá por 2012 con un primer volumen dedicado al cine popular del tardofranquismo. Este proyecto, coordinado en sus dos primeras entregas por M.A. Huerta y E. Pérez Morán, ha sido dirigido desde su tercer volumen por José Luis Sánchez Noriega, quien tomó sus riendas en 2014 con Filmando el cambio social. Las películas de la transición y sigue liderándolo en la actualidad con esta última entrega, cuyo título reza Cine español en la era digital: emergencias y encrucijadas, abarcando un horizonte temporal que se inicia en el año 1996 y concluye en el 2011.

Al igual que en entregas anteriores, los límites temporales del título (con una corrección de dos ańos por delante y uno por detrás, achacables a los tempos industriales de la producción cinematográfica) vienen marcados por los cambios de gobierno y de contexto social, económico y cultural: nueva generación de directores, acceso de las mujeres a trabajos de dirección y de guion, crisis económica, fin de ETA, novedades políticas a raíz del 15-M...

En el texto que inaugura el libro, el profesor José Luis Sánchez Noriega justifica la elección de los dos términos que componen su título y que resultan de lo más representativos respecto al contenido que encontraremos en sus páginas: "hablamos de emergencias como surgimientos, revelaciones, manifestaciones inesperadas de cineastas con obras y estilos difíciles de catalogar; entendemos encrucijadas como cruces de caminos y como retos".

Todo ello dentro del marco que conlleva la entrada en la era digital en cuanto a la producción y la exhibición cinematográfica, así como el cambio que esta circunstancia extraordinaria ha supuesto en los hábitos del espectador. Por esta misma razón, podríamos deducir que nos encontramos ante el trabajo bisagra de este proyecto, aquel que ayuda a interpretar el cambio más traumático que ha sufrido el cine (no solo español) desde su nacimiento, así como a comprender el desarrollo de los acontecimientos en este marco a partir del cambio de era.

Una vez más, la estructura de esta nueva entrega se antoja de lo más acertada teniendo en cuenta sus principales objetivos. En un primer epígrafe, titulado 'De la ruptura del consenso al impacto de la crisis económica. La Espańa de Aznar y Zapatero', Juan Carlos Pereira Castañares realiza un repaso por los hitos políticos, sociales y culturales que marcaron los giros de guion del relato narrado en este volumen. Gracias a sus 
páginas revivimos una parte del pasado reciente de nuestra historia y nos ubicamos mentalmente de cara a la asimilación del siguiente epígrafe, más centrado en el aspecto cinematográfico. La estrategia se revela de lo más acertada: nada como entender el contexto político-social de la época como para poder interpretar el porqué de los cambios, mutaciones y transiciones de la cultura en ella desarrollada.

Es entonces cuando Ernesto Pérez Morán y José Luis Sánchez Noriega nos brindan una panorámica que abarca desde las nuevas pantallas hasta la polifonía audiovisual. En ella, se abre un espacio para abordar el fenómeno que los autores denominan como "cine desplazado»: la presencia del cine en otros espacios y el derribo de las fronteras por parte de creadores y artistas. En este apartado también se aclaran los aspectos más relevantes de la Ley 15/2001, de 9 de julio, del Cine y se esboza el perfil de su gran artífice: Fernando Lara. Del mismo modo, se repasa la irrupción del cine de no ficción y la aparición de figuras tan relevantes a día de hoy como José Luis Guerín, Albert Serra o Jaime Rosales, sin olvidar las trayectorias concluyentes de cineastas en fase de liquidación. En otro orden de cosas, se realiza un inventario de los géneros explorados, las temáticas abordadas y las figuras más relevantes tanto en unas como en otros, de tal modo que podríamos afirmar que mientras esta obra mira con un ojo al pasado, con el otro enfoca las preocupaciones del presente.

Respondiendo a esas nuevas emergencias referidas en el título de este volumen, se dedica un apartado a las mujeres en el cine español. En palabras de Virginia Guarinos, autora de este epígrafe, «la irrupción de la lucha de las mujeres directoras en el cine español es la emergencia más destacable de toda esta época». Se repasan trayectorias de antiguas directoras y nuevas cineastas, observando el incremento paulatino de películas dirigidas por mujeres hasta llegar al año de máxima producción, el 2007, con un total de veinte títulos. Con el ánimo de interpretar estos hitos, se echa la vista atrás para recordar de dónde venimos y hasta dónde hemos llegado, del mismo modo que se estudian los motivos de ese incremento. Guarinos incide en la variedad temática (universos femeninos, intimismo, marginalidad, otredad, educación, violencia machista, memoria histórica...), genérica (las cineastas empiezan a abordar el documental y la comedia) y estilística de este cine, a pesar del escaso número de cineastas españolas en aquel periodo de tiempo. Por otro lado, se aborda un fenómeno tan peculiar como el de las directoras españolas que dieron el salto al cine internacional, como es el caso de Isabel Coixet o María Ripoll. En definitiva, el texto ayuda a visibilizar ese cine emergente necesitado aún de un fuerte apoyo tanto por parte del público como de las instituciones. A lo largo del texto, también se establece un paralelismo entre las variaciones en las cifras de películas dirigidas por mujeres y los gobiernos en el poder en cada momento, de cara a extraer conclusiones o desmentir suposiciones potencialmente erróneas. Con el ánimo de no quedarse en la superficie del problema, también se repasan los largos periodos en los que el incremento fue negativo, incluso a pesar de que se duplicara el número de películas producidas en nuestro país (en 1996, de 91 películas en total 8 fueron dirigidas por mujeres mientras que en 2012 la ratio fue de 182 a 9).

En el apartado dedicado a la transformación del público español se propone un enfoque desde tres perspectivas diferentes. Por un lado, Fernando Arenas se centra en el análisis del número de espectadores anuales, sus variaciones significativas y el fenómeno de las películas "evento", así como su repercusión en la lectura de estas cifras. Del mismo modo, realiza un estudio sobre la evolución en el número de salas y su distribución territorial. Inevitablemente, se abordan el fenómeno de las multisalas y el cambio en la tendencia en el consumo cinematográfico (de las salas al hogar, en un viaje desde la experiencia colectiva a la individual), lo cual propicia la apertura de nuevos espacios de cara a la proyección de trabajos más artísticos. Por otro lado, este apartado indaga en la percepción del cine español por parte del espectador patrio durante la época que abarca este volumen y en el consiguiente estigma de largo recorrido que, durante muchos años, condenó nuestra cinematografía a no ser profeta en su propia tierra.

La segunda mitad del libro está dedicada al análisis de ciento treinta y una películas corres- 
pondientes a esa horquilla comprendida entre 1996-2011. La selección es cuidadosa y reparte su atención entre el cine de masas y las piezas de arte y ensayo con el objetivo de alcanzar un espectro suficientemente representativo de la producción de la época. A su vez, este tramo está dividido en secciones temporales encabezadas por un título propio y marcadas por acontecimientos especialmente relevantes. Para contextualizar cada tramo, cada lote de películas es precedido por una cronología breve que repasa los hitos sociales, políticos y económicos más relevantes de cada época, encaminado a la comprensión del cine resultante y a la comprobación de la permeabilidad del arte respecto a todo aquello que lo rodea. Ya en los textos dedicados a cada film, hallamos una breve sinopsis, una composición de lugar sobre la obra en el marco de la filmografía del cineasta en cuestión, un escueto contenido crítico y un útil repaso a la recepción crítica de la película en el momento de su estreno.

Todos estos epígrafes constituyen una obra que, mediante su abordaje poliédrico del arte cinematográfico, facilita una lectura certera del cine realizado en el marco temporal propuesto por esta entrega. De esta manera, Sánchez Noriega evita la tentación de interpretar el arte cinematográfico de la época (y de las repasadas en volúmenes anteriores) al margen de todos aquellos contextos que han moldeado su fondo y sus formas. Mediante este análisis tan concienzudo, somos invitados a un estudio menos ensimismado del arte y más centrado en su consumidor principal: el ser humano.

Carlos Fernández Castro

Universidad Autónoma de Madrid

DOI: https://doi.org/10.25145/j.latente.2021.19.07 


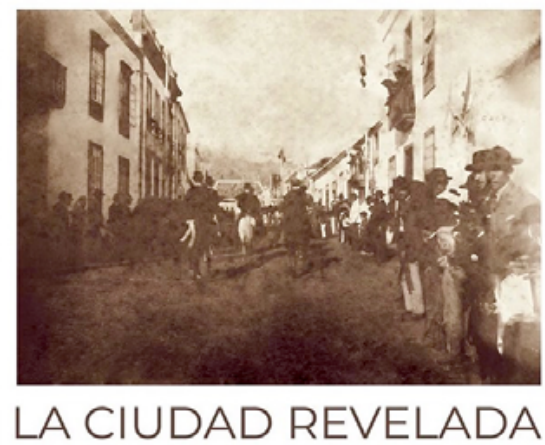

La fotografía en Los Llanos de Aridane

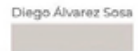

Diego Álvarez Sosa (2021). La ciudad revelada. La fotografía en Los Llanos de Aridane, Concejalía de Cultura, Excmo. Ayto. de Los Llanos de Aridane: Mestura Estudio Ediciones.

Hay momentos en los que se hace necesario felicitarse por la publicación de libros como el que aquí nos ocupa. Independientemente del interés del atractivo texto del autor, que recorre la historia de la fotografía en este municipio palmero, lo mejor de esta publicación es dar a conocer una colección incontestable de imágenes que había ido recogiendo durante su vida Cayetano Gómez Felipe y que hasta ahora no solo estaba descatalogada, sino que era inaccesible, tanto para los investigadores como para el gran público.

El autor, encargado del archivo fotográfico de la lagunera Casa Museo Cayetano Gómez Felipe, hace un seductor ejercicio de recuperación de la memoria llanense a través de cientos de fotografías con un indudable valor etnográfico, antropológico, histórico y documental, aunque muchas de ellas sean simplemente el recuerdo de la vida de la familia del coleccionista, lo que añade a la obra el pudor emocional que supone mostrar los acontecimientos cotidianos de tus seres queridos.

Sobra decir que la publicación es exquisita, tanto en la forma como en el fondo, y las reproducciones, de altísima calidad, incluso respetan el tamaño exacto de las fotografías originales, así como el deterioro con el que han llegado hasta nuestros días, lo que, sin duda, se debe al cariño y respeto del autor hacia los materiales que maneja.

Álvarez Sosa comienza el libro introduciéndonos en el archivo fotográfico del coleccionista palmero, aporta breves pinceladas biográficas e informa del origen de la mayoría de las imágenes reunidas y las diferentes tipologías: paisajes, retratos de gabinete, tarjetas de visita... o de los procesos, como los primitivos daguerrotipos. El resto de las algo más de cuatrocientas páginas articulan un recorrido cronológico que hace paradas en seis estaciones diferentes: la llegada de la fotografía a Los Llanos; la tarjeta de visita como ritual social; los retratos de gabinete; la fotografía de paisaje decimonónica; la tarjeta postal ilustrada; y la democratización de la fotografía en el siglo pasado; para terminar con breves reseńas biográficas de algunos de los personajes y familias fotografiados, interesante para la historia local pero absolutamente inusual en este tipo de publicaciones.

El texto no aborda una investigación exhaustiva, pues quizá el perfil del lector medio que se acerque a la misma no lo requiera, pero sí aporta abundante información para futuros estudios y, sobre todo, tiene la virtud de ofrecer una lectura ligera y atractiva que demuestra la habilidad del autor para la divulgación histórica, lo que no suele ser muy común en compilaciones de estas características.

Aunque el libro se circunscribe espacialmente al municipio palmero que le da nombre, gran parte de la información que nos aporta podría ser claramente extrapolable al resto de las islas, como claramente se nos indica: «las imágenes aridanenses no podrían asimilarse como es debido descontextualizadas de un marco geográfico más amplio». Por tanto, este trabajo da a conocer e «incorpora» esta colección al inventario de la fotografía en Canarias realizado por el equipo del profesor Carmelo Vega, quien ya había trabajado con los fondos del Archivo Municipal de Los Llanos de Aridane. Todo ello permite, una vez más, hacernos idea de la magnitud de los archivos de estas características que existen en manos privadas a lo largo y ancho del Archipiélago; pero también de la necesidad de conservarlos, así como de estudiarlos y compar- 
tirlos, para un mejor conocimiento de la historia de nuestras islas.

Sin duda, este trabajo descriptivo e iconográfico aporta información de carácter social, etnográfico y artístico, toda ella fundamental para entender la dimensión del patrimonio cultural insular y poder así contextualizarlo en relación con la historia de la fotografía en Canarias.

Mención especial merece el capítulo dedicado a los gabinetes profesionales de Los Llanos, especialmente los de Miguel Brito, José Rodríguez Roda y Manuel Rodríguez Quintero, de quienes se aporta un número importante de imágenes, así como un breve recorrido por sus estudios, pudiéndose incluso vislumbrar las pequeñas diferencias en cuestiones de estética fotográfica de cada uno de ellos y sus estilos personales.

En definitiva, retomando las palabras en la Introducción de Jesús Pérez Morera, «este libro cumple con un servicio social y cubre una necesidad imperiosa en la sociedad actual, urgida de reconocerse y reencontrarse (...) con nuestra verdadera identidad». Es así como la obra es fiel reflejo de quienes fuimos y quienes somos y, por tanto, un documento imperecedero.

Domingo Sola Antequera

Dept. H. ${ }^{a}$ del Arte y Filosofía

Universidad de La Laguna

DOI: https://doi.org/10.25145/j.latente.2021.19.08 



\section{REVISORES}

Isabel Castells Molina

Alicia Hernández Vicente

Amparo Martínez Hernández

Gonzalo Pavés Borges

Enrique Ramírez Guedes

Domingo Sola Antequera

Carmelo Vega de la Rosa 
INFORME ANUAL DEL PROCESO EDITORIAL DE LATENTE 19 (2021)

El promedio de tiempo de publicación desde la llegada de los artículos a la Redacción de la revista hasta su aprobación es de 2-3 meses y hasta la publicación, de unos 6 meses. Los evaluadores/as son miembros de diversas facultades de esta universidad, así como de otros centros nacionales e internacionales, y forman parte de los diversos comités de Latente.

\section{Estadísticas:}

N. ${ }^{\circ}$ de artículos recibidos: 11

N. ${ }^{\circ}$ de artículos aceptados: 8

Promedio de evaluadores/as por artículo: 2

Promedio de tiempo entre llegada y aceptación de artículos: 2-3 meses

Promedio de tiempo entre aceptación y publicación: 6 meses

El 72,7\% de los manuscritos enviados a Latente han sido aceptados para su publicación. 
